DAVID BELLENTANI ROCHA

\title{
ESTUDO DA SOLDABILIDADE DO TUBO API 5L X80 UTILIZANDO OS PROCESSOS DE SOLDAGEM: MAG COM TRANSFERÊNCIA CONTROLADA E ELETRODO TUBULAR
}

\author{
Dissertação apresentada à \\ Escola Politécnica da \\ Universidade de São Paulo \\ para obtenção do título de \\ Mestre em Engenharia
}

São Paulo

2010 
DAVID BELLENTANI ROCHA

\section{ESTUDO DA SOLDABILIDADE DO TUBO API 5L X80 UTILIZANDO OS PROCESSOS DE SOLDAGEM: MAG COM TRANSFERÊNCIA CONTROLADA E ELETRODO TUBULAR}

Dissertação apresentada à Escola Politécnica da Universidade de São Paulo para obtenção do título de Mestrado em Engenharia

Área de concentração:

Engenharia Metalúrgica e de Materiais

Orientador:

Professor Dr. Sérgio Duarte Brandi

São Paulo

2010 
Este exemplar foi revisado e alterado em relação à versão original, sob responsabilidade única do autor e com a anuência de seu orientador.

São Paulo, 11 de abril de 2010

Assinatura do autor

Assinatura do orientador

\section{FICHA CATALOGRÁFICA}

Rocha, David Bellentani

ESTUDO DA SOLDABILIDADE DO TUBO API 5L X80 UTILIZANDO OS PROCESSOS DE SOLDAGEM: MAG COM TRANSFERENNCIA CONTROLADA E ELETRODO TUBULAR / D.B. Rocha. -São Paulo, 2010.

219 pp.

Dissertação (Mestrado) - Escola Politécnica da Universidade de São Paulo. Departamento de Engenharia Metalúrgica e de Materiais.

1. Soldagem 2. Soldagem com eletrodo tubular 3. Soldagem: aços ARBL 4. Aço API 5L X80 I. Universidade de São Paulo. Escola Politécnica. Departamento de Engenharia Metalúrgica e de Materiais II. t. 
"Feliz aquele que transfere o que sabe e aprende o que ensina."

Cora Coralina 


\section{DEDICATÓRIA}

Dedico este trabalho a minha noiva Luana, a meus pais Gilberto e Maria Aparecida, a meu irmão André e especialmente a minha avó Angelina. 


\section{AGRADECIMENTOS}

A Deus em primeiro lugar;

Ao professor Sérgio Duarte Brandi, por ter me orientado nesta árdua tarefa;

A toda minha família pelo seu amor, carinho e dedicação;

A minha noiva Luana por seu carinho, compreensão e incentivo;

Aos meus amigos da Poli - Metalurgia: José Ramalho, Flávio, Lívio, Ivo, Fábio, Danilo, André, Paulo, Diego, Marcelo, Wilmar, Anderson, Horácio, Marcão, Rafael, Vinícius, Cláudio, Rubão, Dairo, Daniel, Mario, entre muitos outros;

Aos Professores do Departamento de Soldagem da FATEC-SP;

Aos meus amigos da FATEC-SP pela ajuda e incentivo para a execução deste trabalho;

A Prof. Dra. Neusa Alonso-Falleiros e Prof. Dra. Idalina Vieira Aoki pelos ensinamentos de corrosão;

Ao Prof. Landgraf e Bruno do IPT pela colaboração e ensaios de saturação magnética;

A todos os meus colegas de trabalho da Inspeção de Equipamentos da Refinaria de Capuava - RECAP/IE;

Aos colegas Eduardo Hippert Jr, Gilmar Zacca, Marcos Alex, Elias Souza, Marcos Gabriel, Rodrigo Viotto, Alice Martins, Antonio Domingos, entre muitos outros, pela paciência, colaboração e participação;

A Proaqt pela ajuda e ensaios realizados, especialmente ao Corradini, Mario e Júlio;

A Lincoln Electric do Brasil pela viabilização e execução da soldagem, especialmente aos meus amigos, Carlos, Diego, Zorailde, Danielle, Antonio Souza e Paulo Brito;

A Petróleo Brasileiro S.A. - PETROBRAS, empresa da qual tenho orgulho de participar;

A todos que, direta ou indiretamente, ajudaram ou atrapalharam a execução do presente trabalho. 


\section{RESUMO}

Os tubos API 5L X80, construídos com aços alta resistência e baixa liga, são especificados para a construção de dutos para transporte de petróleo e derivados sob alta pressão, com conseqüente redução no peso dos tubos. $O$ processo mais empregado para a soldagem circunferencial de tubos em campo no Brasil é o processo com eletrodo revestido, tanto para o passe de raiz quanto para os passes de enchimento. Uma alternativa para o passe de raiz é o processo de soldagem MAG com Transferência Controlada (MAG-TC), enquanto que o enchimento pode ser feito com o processo de soldagem utilizando eletrodo tubular (AT), tanto o auto-protegido (AT-AP) como o com proteção gasosa (AT-PG). Esta combinação de processos (MAG-TC + AT) apresenta-se como um promissor substituto do processo de soldagem com eletrodo revestido, reunindo alta qualidade do metal de solda depositado e alta produtividade.

O objetivo deste trabalho é estudar a soldabilidade do tubo API $5 \mathrm{~L}$ X80 nacional, com 508 mm (20") de diâmetro e 19 mm (3/4") de espessura, comparando-se duas combinações de processos de soldagem circunferencial: MAG-TC + AT-PG e MAG-TC + AT-AP. A soldagem foi realizada com o arame ER80S-G no passe de raiz e processo MAG-TC com proteção de $\mathrm{CO}_{2}$. $\mathrm{O}$ enchimento foi feito com os arames E101T1-GM-H8 (com proteção gasosa) e E91T8-G (auto-protegido). Foram fixadas as temperaturas de pré-aquecimento $\left(150{ }^{\circ} \mathrm{C}\right)$ e interpasse $\left(250{ }^{\circ} \mathrm{C}\right)$ para ambas combinações de processos de soldagem. As juntas foram caracterizadas utilizando-se: análise química, saturação magnética, metalografia óptica e eletrônica de varredura e ensaios mecânicos: dureza Vickers, tração, dobramento, 'nick-break' e ensaio de impacto a $0^{\circ} \mathrm{C}$. Foi seguido como referência os requisitos técnicos básicos para a qualificação de um procedimento de soldagem conforme a norma API 1104.

Os resultados mostraram que, segundo os critérios da norma API 1104, apenas uma das combinações de processos foi aprovada, sendo a outra reprovada no ensaio 'nick-break' devido à ocorrência de falta de fusão na raiz de um dos quadrantes. O processo MAG-TC na raiz exige uma habilidade específica do soldador. 


\begin{abstract}
API 5L X80 pipes, built with high strength - low alloy steel, are specified for the construction of pipelines to transport oil and oil products under high pressure, with consequent reduction in weight of the tubes. The most often pipeline construction used for welding circumferential pipe field in Brazil is the SMAW process, for root and filling passes. An alternative welding process to the root pass is the GMAW-STT $尺$ process, while the filling passes can be welded with FCAW-G (Flux Cored Arc Welding with Gas shielding) and FCAW$S$ (Flux Cored Arc Welding with Self shielding). This combination of processes (GMAW-STT ${ }^{\circ}+$ FCAW) is presented as a promising substitute for the SMAW process, bringing high-quality weld metal deposited and high productivity.

The objective of this work is to study the weldability of the Brazilian API 5L X80 pipe, with $508 \mathrm{~mm}$ (20 inches) in diameter and $19 \mathrm{~mm}$ (3 / 4 inch) thick, comparing the two combinations of circumferential welding processes: GMAWSTTR + FCAW-G and GMAW-STT $®$ + FCAW-S. The welding was done with the ER80S-G wire in the root pass and process GMAW-STT $®$ using pure $\mathrm{CO}_{2}$ as shielding gas. The filling passes were made with the wires E101T1-GM-H8 for FCAW-G and E91T8-G for FCAW-S. Preheat and interpass temperatures were kept constant, respectively $150^{\circ} \mathrm{C}$ and $250{ }^{\circ} \mathrm{C}$ for both welding processes combinations. The joints were characterized using: chemical analysis, magnetic saturation, optical metallography and scanning electron microscopy and mechanical tests such as: Vickers hardness, tensile, bending, nick-break and Charpy $\mathrm{V}$ test at $0^{\circ} \mathrm{C}$. It was followed API 1104 standard as reference to the basic technical requirements for the qualification of a welding procedures.

The results showed that, according to the criteria of the API 1104 standard, only one combination of the two processes was approved. The other combination was reproved in the nick-break test due to lack of fusion occurred in one of the quadrants in the root pass. The GMAW-STT® process at the root pass requires a specific skill of the welder.
\end{abstract}




\section{LISTA DE FIGURAS:}

Figura 1 Gráfico custo/resistência mecânica de aços para tubos API 5L [5].... 36 Figura 2 - Desenvolvimento dos aços API 5L desde a década de 50. Baseado na ref. [12].

Figura 3 - Desenvolvimento dos aços API 5L, elementos de liga e rota de produção. Baseado na ref. [5].

Figura 4- Ciclo de laminação controlada, apresentando o tempo de espera entre as etapas de laminação e as etapas de refrigeração possíveis [20]. ...... 41 Figura 5- Micrografia do aço utilizado pela ref. [18], mostrando os diferentes microconstituintes. Ampliação 1000x.

Figura 6- Micrografia dos aços utilizados pela ref. [27], mostrando as ilhas de MA (Martensita-Austenita) em matriz ferrítica. (a) Aço ligado ao NbCrMo (b) Aço ligado ao $\mathrm{NbCr}$.

Figura 7- Algumas das opções metalúrgicas de obtenção de aços API 5L X80.

Figura baseada na ref. [31].

Figura 8- Influência dos elementos $\mathrm{Ti}, \mathrm{Nb}, \mathrm{Al}$ e $\mathrm{V}$ na temperatura de término de recristalização em um aço contendo $0,07 \% \mathrm{C}, 1,40 \% \mathrm{Mn}$ e $0,25 \%$ Si. ref. [12]. . 49 Figura 9 - Influência do nitrogênio em relação ao teor de titânio na energia absorvida no ensaio de impacto Charpy.ref. [12].

Figura 10 - Teor e efeito dos elementos de liga em relação à faixa de temperatura da ferrita $\delta$ na tendência de formação de linha central de segregação. ref. [12].

Figura 11 - Limite de escoamento em função das classes de aços API. Figura baseada na referência [38].

Figura 12 - Curva de transição dúctil-frágil do aço estudado por Roza [18] no sentido transversal. A linha tracejada representa $50 \%$ de fratura dúctil. Nota-se que a temperatura de transição ficou abaixo de $-60^{\circ} \mathrm{C}$.

Figura 13 - Conformação da chapa no formato "U". Detalhe: Bordas prensadas no sentido da curvatura do tubo. Figura baseada na ref. [42]. ........................ 57

Figura 14 - Etapas do processo de fabricação UOE [15].

Figura 15 - Ilustração da poça de fusão do processo de soldagem SAS. Ref [1].

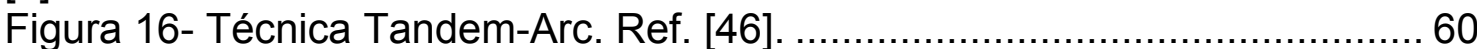

Figura 17- llustração da função dos eletrodos - Tandem-Arc. Ref [46]. .......... 60

Figura 18- Variação da energia absorvida com a região da junta soldada, em

relação a energia de soldagem utilizada Ref. [11]

Figura 19- Relação entre a energia de soldagem e a espessura, utilizando-se a técnica Tandem-Arc com 4 eletrodos. Ref. [11] ....................................... 62 Figura 20- Representação das diversas regiões de uma junta soldada [51]. .. 63 Figura 21- Representação esquemática da fragilização por hidrogênio, mostrando a absorção e a difusão do hidrogênio durante a soldagem, segundo Granjon [54].

Figura 22- Trinca por hidrogênio na margem solda em um tubo de aço de alta resistência [22].

Figura 23- Relação entre a temperatura de pré-aquecimento em função do carbono equivalente [16].

Figura 24-Curvas de resfriamento contínuo (CRC) para o aço API X80. (a) ref. 62; (b) ref. 63; (c) ref. 64 baixo Mn e Si e (d) ref. 64 alto Mn e Si. 
Figura 25- Micrografia ZAC e do metal de solda dos aços estudados por Bott [27]. (a) e (c) liga NbCrMo; (b) e (d) liga NbCr. ........................................ 74

Figura 26- llustração do processo de soldagem MAG [45] ............................ 76

Figura 27- Formato de onda do processo MAG-TC [69]. ............................ 77

Figura 28- Perfil do cordão de solda obtido pelos processos de soldagem ER e

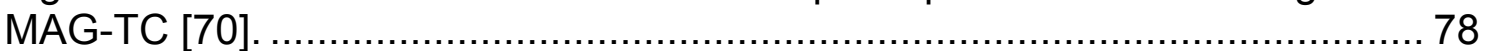

Figura 29 - (a) llustração do processo AT-PG; (b) llustração do processo AT-AP $[45,71]$

Figura 30- Exemplo de curva de magnetização para duas amostras tratadas termicamente, apresentando a variação da magnetização "Jsat" em função do campo magnético "H" aplicado. Figura baseada na ref. [74] ......................... 83 Figura 31- Região de extração dos corpos de prova, conforme API 1104 [7]. 91 Figura 32- Identificação e localização dos quadrantes, baseado na API 1104 [7]. 91

Figura 33- Pontos e distância de monitoramento da temperatura de pré-

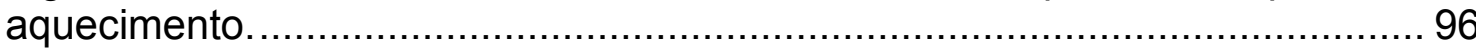

Figura 34- Pontos de coleta de parâmetros por quadrante. .......................... 97

Figura 35- Região de extração dos corpos de prova para os ensaios metalográficos e químicos, representando as posições de soldagem. …........ 98 Figura 36- Regiões de extração dos corpos de prova para o ensaio de saturação magnética. 100

Figura 37- Dimensão dos corpos de prova para o ensaio de saturação magnética. OBS: Dimensões em mm

Figura 38- Pontos de ensaio de espectrometria para determinação da composição química.

Figura 39- Pontos utilizados para medição de dureza. Baseado na ref. [77]. 102 Figura 40- Dimensões dos corpos de prova do ensaio de tração, conforme API 1104 [9].

Figura 41- Região de extração e dimensão dos corpos de prova no sentido longitudinal [9].

Figura 42- Região de extração e dimensões dos corpos de prova - sentido transversal [9].

Figura 43- Dimensões dos corpos de prova do ensaio de dobramento lateral, conforme API 1104 [8] 105 Figura 44- Dimensões dos corpos de prova do ensaio de Nick-break e entalhe adicional recomendado pela API 1104 para corpos de prova soldados com processos mecanizados ou semi-automáticos, conforme API 1104 [8] ........ 106 Figura 45- Regiões de extração dos corpos de prova do ensaio de impacto Charpy-V.

Figura 46- Dimensões dos corpos de prova do ensaio de impacto Charpy-V, conforme ASTM A370 [78]. OBS: Dimensões em mm................................. 108 Figura 47- Regiões de extração dos corpos de prova do ensaio de impacto Charpy-V no metal de base do tubo, conforme API 5L [9] ........................... 108 Figura 48: Elementos de liga em maior quantidade, segundo tabela 25....... 110 Figura 49: Elementos de liga em maior quantidade, segundo tabela 25....... 110 Figura 50: Variação da composição química do metal de solda em relação ao metal de base e o certificado dos consumíveis para o tubo 1 ....................... 113 Figura 51: Variação da composição química do metal de solda em relação ao metal de base e o certificado dos consumíveis para o tubo 1 . 
Figura 52: Variação da composição química do metal de solda em relação ao metal de base e o certificado dos consumíveis para o tubo 2 ....................... 115 Figura 53: Variação da composição química do metal de solda em relação ao metal de base e o certificado dos consumíveis para o tubo 2 ....................... 116 Figura 54: Variação do carbono equivalente segundo composição química do metal de solda em relação ao metal de base........................................... 117 Figura 55: Tempo de resfriamento entre 800 e $500^{\circ} \mathrm{C}$, de acordo com os dados da tabela 26 . 123 Figura 56: Tempo de resfriamento entre 800 e $500^{\circ} \mathrm{C}$, de acordo com os dados da tabela 27 . 125

Figura 57: Dureza versus tempo de resfriamento entre 800 e $500^{\circ} \mathrm{C}$, de acordo com os dados das ref. 26,73 e 74 . 127 Figura 58 - Velocidade de resfriamento para diferentes temperaturas. Tubo 1

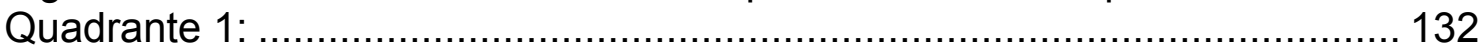
Figura 59 - Velocidade de resfriamento para diferentes temperaturas. Tubo 1 Quadrante 2: 132 Figura 60 - Velocidade de resfriamento para diferentes temperaturas. Tubo 1 Quadrante 3:

Figura 61 - Velocidade de resfriamento para diferentes temperaturas. Tubo 1 Quadrante 4:

Figura 62 - Velocidade de resfriamento para diferentes temperaturas. Tubo 2 Quadrante 1:

Figura 63 - Velocidade de resfriamento para diferentes temperaturas. Tubo 2 Quadrante 2:

Figura 64 - Velocidade de resfriamento para diferentes temperaturas. Tubo 2 Quadrante 3:

Figura 65 - Velocidade de resfriamento para diferentes temperaturas. Tubo 2

Quadrante 4:

Figura 66-Macrografia das soldas do tubo 1 nas posições indicadas pela figura 34.(a) posição plana;(b) posição vertical direita; (c) posição vertical esquerda:

(d) posição sobre-cabeça.

Figura 67- Macrografia das soldas do tubo 2 nas posições indicadas pela figura 34. .(a) posição plana;(b) posição vertical direita; (c) posição vertical esquerda:

(d) posição sobre-cabeça................................................................... 143

Figura 68- Exemplo de medida da extensão da ZAC............................... 144

Figura 69 - Extensão da ZAC para o tubo 1, de acordo com os dados da tabela

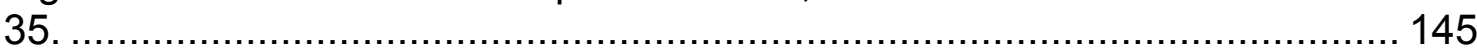

Figura 70 Extensão da ZAC para o tubo 2, de acordo com os dados da tabela

36.................................................................................. 146

Figura 71 - Microestrutura do metal de base montada em formato de cubo para permitir a visualização da sua anisotropia.............................................. 147

Figura 72 - Montagem da microestrutura do passe de raiz do tubo 1, em direção ao metal de base, mostrando a zona fundida (a), a zona de ligação (b), a ZAC (c, d) e o metal base (e). Ataque: Nital 2\%................................... 148 Figura 73- Montagem da microestrutura do passe de raiz do tubo 1, em direção ao metal de base, mostrando a zona fundida (a), a zona de ligação (b), a ZAC (c, d) e o metal base (e). Ataques: Nital $2 \%$ e Klemm 1 com filtro azul. Aumento: $1000 \mathrm{X}$ 149

Figura 74- Montagem da microestrutura do metal de solda do passe de enchimento do tubo 1 . Ataque: Nital $2 \%$. 
Figura 75 - Região de cruzamento entre o passe de raiz e a primeira camada do enchimento do tubo 1, mostrando o metal de solda do passe de enchimento (a), o metal de solda do passe de raiz (b) e a ZAC do metal de base (c).

Ataque: Nital $2 \%$.

Figura 76 - Região de cruzamento entre o passe de raiz e a primeira camada do enchimento do tubo 2, apresentando detalhes da microestrutura da raiz (a) e da ZAC (b). Ataques: Nital $2 \%$ e Klemm1 com filtro azul.

Figura 77- Região de cruzamento do metal de solda de três cordões na região de enchimento do tubo 2, mostrando as respectivas ZACs. Ataque: Nital $2 \%$.

Figura 78- Microestrutura do metal de solda da raiz do tubo 2. Ataque: Nital 2\%. Aumento: 500X.

Figura 79 - Microestrutura da zona de ligação do metal de solda da raiz do tubo 2 com a ZAC. Ataque: Nital 2\%. Aumento: 500X.

Figura 80 - Teor de MA para as amostras das posições de soldagem plana e vertical, de ambos os tubos. A linha tracejada mostra a média do MA do metal de base.

Figura 81- Teor de MA em função do tempo de resfriamento entre 800 e $500^{\circ} \mathrm{C}$

Figura 82- Teor de MA estimado através de metalografia quantitativa das micrografias das figuras 73 e 76.

Figura 83 - Durezas Vickers HV5 das regiões soldadas do tubo 1 em função das posições de soldagem e camadas, baseada nos dados da tabela 38.... 162 Figura 84 - Durezas Vickers HV5 das regiões soldadas do tubo 2 em função das posições de soldagem e camadas, baseada nos dados da tabela $40 . . . .164$ Figura 85 - Propriedades mecânicas do metal de base e da solda longitudinal do tubo, conforme API 5L [9].

Figura 86 - Fractografia de um corpo de prova de tração do metal de base no sentido longitudinal, apresentando caráter dúctil. (a) baixo aumento (50X); (b) maior aumento (800X)

Figura 87 - Limite de resistência das soldas circunferenciais, conforme API 1104 [8].

Figura 88 - Região e face da fratura do corpo de prova de tração do quadrante

3 do tubo 2.

Figura 89 - Região e face da fratura do corpo de prova de tração da figura 86 , que rompeu na zona de ligação.

Figura 90 - Exemplos de corpos de prova do ensaio de dobramento. (a) Corpo de prova do tubo 1, quadrante 1 apresentando trinca de $2,5 \mathrm{~mm}$ de comprimento; (b) Corpo de prova de dobramento do tubo 2, quadrante 1 , isento de descontinuidades.

Figura 91 - Região com falta de fusão no passe de raiz no quadrante 2 do tubo 1 , mostrando o cordão interrompido e o cordão de reinício. 175 Figura 92 - Região com falta de fusão no passe de raiz no quadrante 2 do tubo 1 , mostrando interface entre a falta de fusão a região de início de fratura dúctil.

Figura 93 - Montagem em 3D apresentando a fractografia da região com falta de fusão no passe de raiz no quadrante 2 do tubo 1, mostrando interface entre a falta de fusão a região de fratura dúctil. 176 Figura 94 - Análise por EDS da região clara na falta de fusão da figura acima. 
Figura 95- Face da fratura dos corpos de prova do ensaio nick-break para o tubo 1, obtidas em lupa estereoscópica.

Figura 96 - Face da fratura dos corpos de prova do ensaio nick-break para o tubo 2, obtidas em lupa estereoscópica.

Figura 97- Face da fratura dos corpos de prova do ensaio nick-break para o tubo 1, obtidas em MEV. (a) enchimento; (b) raiz.

Figura 98- Montagem em 3D apresentando a fractografia da região de fratura do corpo de prova T1Q2-NB do tubo 1, na região do enchimento, apresentando caráter dúctil. 180

Figura 99- Montagem em 3D apresentando a fractografia da região de fratura do corpo de prova T1Q2-NB do tubo 1, na região da raiz, apresentando caráter frágil. 180

Figura 100 - Energia absorvida pelas diferentes regiões da junta soldada do tubo 1, nos quatro quadrantes.

Figura 101 - Face da fratura de corpo de prova do ensaio de impacto do metal base, obtida com o auxílio de microscópio eletrônico de varredura. 182 Figura 102- Face da fratura dos corpos de prova do ensaio de impacto na região da raiz do quadrante 2 do tubo 1, obtidas com o auxílio de microscópio eletrônico de varredura, apresentando caráter frágil.

Figura 103- Face da fratura do corpo de prova do quadrante 2 do tubo 1 na região do enchimento, obtidas através de microscopia eletrônica de varredura, apresentando caráter dúctil-frágil.

Figura 104- Face da fratura do corpo de prova do quadrante 2 do tubo 1 obtidas através de microscopia eletrônica de varredura, apresentando fratura com comportamento dúctil na ZAC.

Figura 105 - Região de obtenção das micrografias da fratura do corpo de prova do quadrante 4 do tubo 1 . Sentido perpendicular ao entalhe (a), e transversal (b).

Figura 106 - Montagem da microestrutura na região de fratura do corpo de prova da ZAC do quadrante 4 do tubo 1 apresentando propagação na direção do metal de base, mostrando o metal de solda (a), a ZAC (b), ZAC na região intercrítica (c) e região de fratura (e). Nota-se a semelhança da microestrutura com a da face superior do cubo da figura 71.

Figura 107 - Montagem da microestrutura na região de fratura do corpo de prova da ZAC do quadrante 4 do tubo 1 apresentando propagação na direção do metal de base, mostrando o metal de solda (a), a ZAC (b), ZAC na região intercrítica (c) e região de fratura (e). Nota-se a semelhança da microestrutura com a da face superior do cubo da figura 71 .

Figura 108- Energia absorvida pelas diferentes regiões da junta soldada do tubo 2, segundo os quadrantes.

Figura 109- Valores de expansão lateral em relação a região da junta soldada e seus respectivos quadrantes. Tubo 1. 189 Figura 110 - Valores de expansão lateral em relação a região da junta soldada e seus respectivos quadrantes. Tubo 2 . 190 


\section{LISTA DE TABELAS:}

Tabela 1: Composição química típica dos aços da década de 60. Baseada na ref. [22].

Tabela 2- Variação da composição química dos aços X52-X60 durante e década de 70 e início de 80 , produzidos pela rota TMCR. Baseada na ref. [22].

Tabela 3: Composição química típica dos aços X60, X65 e X70 modernos. Ref.

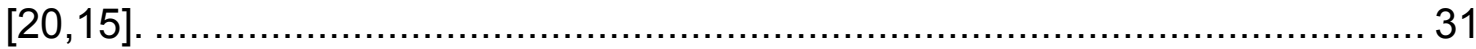

Tabela 4- Composição química dos aços utilizados na Alemanha e Canadá.

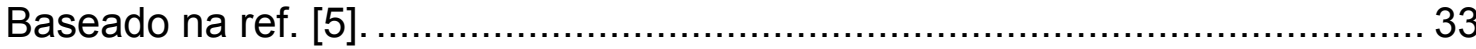

Tabela 5. Composição química típica dos aços X80 produzidos atualmente... 35

Tabela 6 - Composição química dos aços X 100 e X120 experimentais

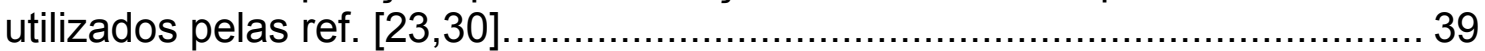

Tabela 7 - Propriedades mecânicas dos aços X100 e X120 experimentais

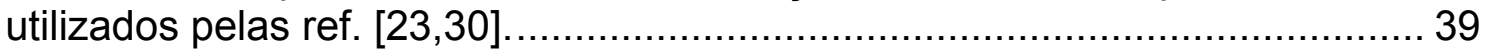
Tabela 8- Composição química do primeiro aço X80 desenvolvido no Brasil.

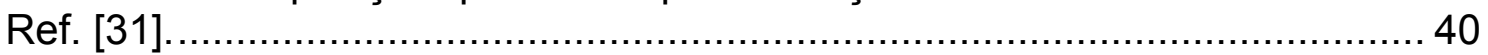
Tabela 9: Composição química do aço API 5L X80 nacional estudado por

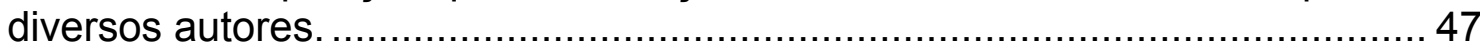
Tabela 10- Requisitos de propriedades mecânicas da API 5L X80 para o grau

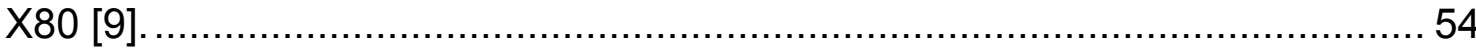

Tabela 11- Propriedades mecânicas do aço estudado por Roza [18] ............. 55 Tabela 12- Eficiência de transferência de calor dos processos de soldagem. Ref. [57]. 69 Tabela 13- Carbono Equivalente dos aços API 5L X80 nacionais estudados por diversos autores. 72 Tabela 14- Fração volumétrica de MA (Martensita-Austenita) no aço estudado

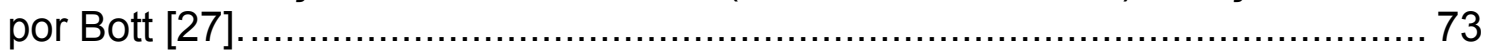
Tabela 15- Consumíveis utilizados na soldagem de tubos X80 com a combinação de processos MAG-TC + AT.

Tabela 16- Composição química do tubo API 5L X80, comparado com os valores especificados pela norma API $5 \mathrm{~L}$.

Tabela 17-Propriedades mecânicas mínimas do consumível utilizado, segundo a especificação AWS, catálogo do fabricante e certificado do lote utilizado $[6,75]$

Tabela 18- Composição química do metal de solda depositado, conforme requerido pela especificação AWS e o informado pelo catálogo do fabricante [6, 75].

Tabela 19- Propriedades mecânicas mínimas dos consumíveis utilizados, segundo a especificação AWS, catálogo do fabricante e certificado do lote utilizado $[7,75,76]$.

Tabela 20- Composição química do metal de solda depositado, conforme requerido pela especificação AWS, catálogo do fabricante e o certificado do lote utilizado $[7,75,76]$.

Tabela 21 - Experimentos, finalidades e identificação dos corpos de prova / junta soldada. .

Tabela 22- Tabela de variáveis estudadas. 
Tabela 23 - Resumo dos parâmetros de soldagem empregados para o tubo 1.

Tabela 24 - Resumo dos parâmetros de soldagem empregados para o tubo 2.

Tabela 25: Composição química do metal de solda dos passes de raiz, enchimento e acabamento do tubo 1 e 2................................................ 109

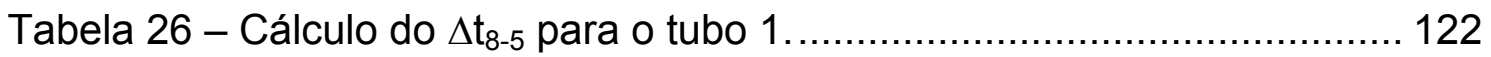

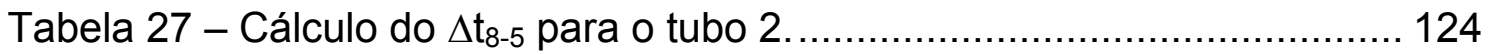

Tabela 28 - Velocidade de resfriamento, em função dos parâmetros de soldagem, para o tubo 1, quadrante 1................................................. 128

Tabela 29 - Velocidade de resfriamento, em função dos parâmetros de soldagem, para o tubo 1, quadrante 2............................................... 129

Tabela 30 - Velocidade de resfriamento, em função dos parâmetros de soldagem, para o tubo 1, quadrante 3.................................................. 130

Tabela 31 - Velocidade de resfriamento, em função dos parâmetros de

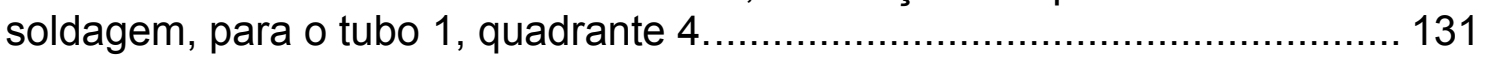

Tabela 32- Velocidade de resfriamento, em função dos parâmetros de soldagem, para o tubo 2, quadrante 1.................................................. 135

Tabela 33- Velocidade de resfriamento, em função dos parâmetros de soldagem, para o tubo 2, quadrante 2................................................. 136

Tabela 34- Velocidade de resfriamento, em função dos parâmetros de soldagem, para o tubo 2, quadrante 3.................................................. 137

Tabela 35 - Velocidade de resfriamento, em função dos parâmetros de soldagem, para o tubo 2, quadrante 4................................................. 138

Tabela 36- Extensão da ZAC de acordo com a posição de soldagem para o

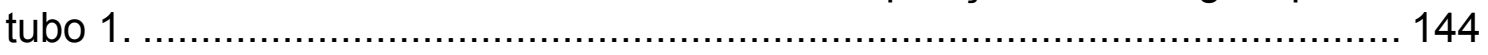

Tabela 37- Extensão da ZAC de acordo com a posição de soldagem para o

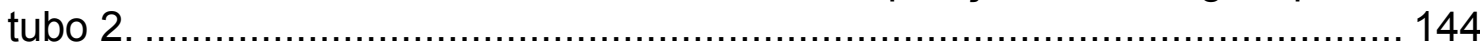

Tabela 38 - Teor de MA das diversas regiões da junta, para as posições plana

e vertical de ambos os tubos................................................................. 157

Tabela 39- Dureza média do metal de base............................................ 160

Tabela 40- Dureza Vickers HV5 das regiões da junta soldada do tubo $1 \mathrm{em}$ função das posições de soldagem e camadas............................................ 161

Tabela 41- Dureza Vickers HV5 das regiões da junta soldada do tubo $2 \mathrm{em}$ função das posições de soldagem e camadas............................................. 163

Tabela 42- Limite de resistência da junta soldada, conforme API 1104........ 169

Tabela 43 - Local de fratura dos corpos de prova do ensaio de tração,

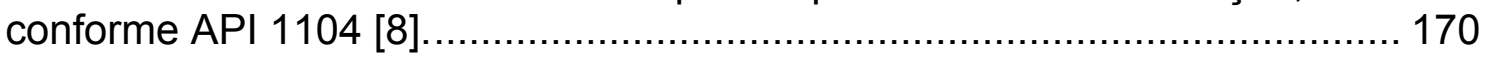

Tabela 44- Resultados do ensaio de dobramento das juntas soldadas. ....... 172

Tabela 45- Resultado do ensaio de Nick-Break. .......................................... 174

Tabela 46- Resultado do ensaio de impacto Charpy $\vee$ a $0{ }^{\circ} \mathrm{C}$......................... 181 


\section{LISTA DE ABREVIATURAS E SIGLAS:}

API: $\quad$ American Petroleum Institute

ARBL: $\quad$ Alta Resistência - Baixa Liga

ASTM: American Society For Testing And Materials

AT: $\quad$ Processo de soldagem Eletrodo Tubular

AT-AP: $\quad$ Processo de soldagem Eletrodo Tubular - Auto Protegido

AT-PG: $\quad$ Processo de soldagem Eletrodo Tubular - Proteção Gasosa

AWS: $\quad$ American Welding Society

CE: $\quad$ Carbono Equivalente

ED: $\quad$ Ensaio destrutivo

END: $\quad$ Ensaio não destrutivo

ER: $\quad$ Processo de soldagem Eletrodo Revestido

ERW: $\quad$ Electrical Resistence Welding - Processo de soldagem por resistência elétrica

EVS: $\quad$ Ensaio Visual de Solda

FCAW-G: Flux Cored Arc Welding - Gas Shielded - Processo de soldagem com Arame Tubular com proteção gasosa

FCAW-S: Flux Cored Arc Welding - Self Shielded - Processo de soldagem com Arame Tubular auto-protegido

GMAW: Gas Metal Arc Welding - Processo de soldagem MIG/MAG

GTAW: $\quad$ Gas Tungsten Arc Welding - Processo de soldagem TIG

HSLA: $\quad$ High Strength - Low Alloy - igual a ARBL

HTP: $\quad$ High Temperature Processing

IIW: International Institute of Welding

Jref: $\quad$ Saturação magnética de referência

Jsat: $\quad$ Saturação magnética

LE: $\quad$ Limite de Escoamento

LR: $\quad$ Limite de Resistência

MA: $\quad$ Martensita - Austenita

MAG: $\quad$ Processo de soldagem MAG

MAG-TC: Processo de soldagem MAG com transferência controlada

MEV: $\quad$ Microscópio Eletrônico de Varredura 
PAC: $\quad$ Plasma Arc Cutting - Processo de corte plasma

Pcm: $\quad$ Parâmetro de Carbono Equivalente

PSL: $\quad$ Product Specification Level

SAS: $\quad$ Processo de soldagem Arco Submerso

SAW: $\quad$ Submerged Arc Welding - Processo de soldagem Arco Submerso

SMAW: $\quad$ Shielded Metal Arc Welding - Processo de soldagem por Eletrodo Revestido

STT®: $\quad$ Surface Tension Transfer® - transferência por tensão superficial

TIG: $\quad$ Processo de soldagem TIG

TMCP: Thermo Mechanical Controlled Processing

TMCR: Thermo Mechanical Controlled Rolling

UOE: $\quad$ Conformação em "U", "O" e Expansão "E"

ZAC: Zona Afetada pelo Calor 


\section{LISTA DE SÍMBOLOS:}

$\alpha: \quad$ Ferrita Alpha

Y: $\quad$ Austenita

ס: $\quad$ Ferrita Delta 


\section{SUMÁRIO:}

1. INTRODUÇÃO E JUSTIFICATIVA:

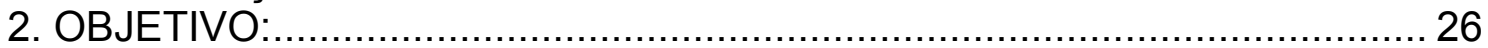

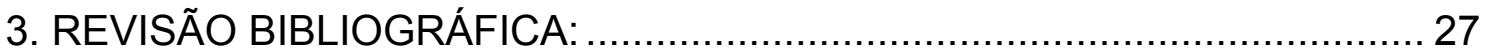

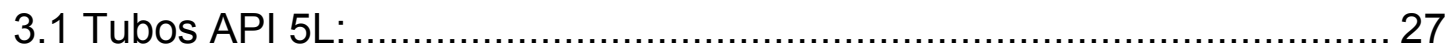

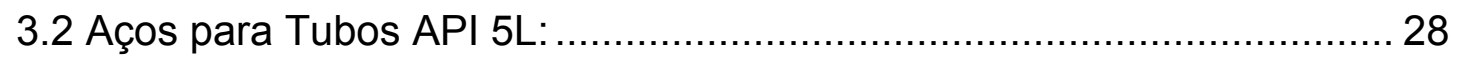

3.2.1 Aços HSLA:

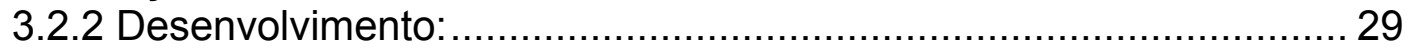

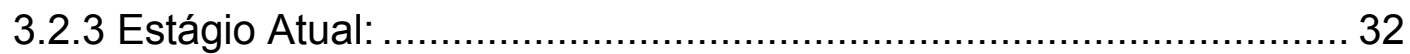

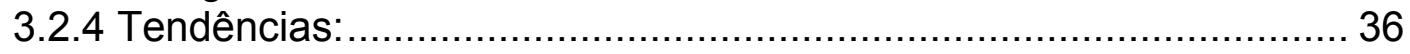

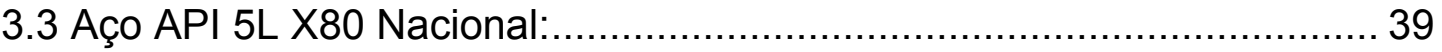

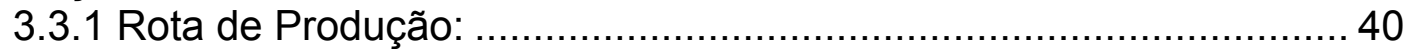

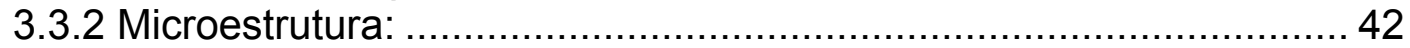

3.3.3 Composição química: ............................................................ 45

3.3.3.1 Efeito dos principais elementos de liga: ................................... 46

3.3.3.2 Efeito dos elementos de microliga:........................................... 48

3.3.3.3 Efeito dos elementos convencionais de liga:............................... 50

3.3.3.4 Efeitos deletérios de impurezas: ........................................... 52

3.3.3.5 Efeitos dos elementos modificadores de inclusões: ……............... 53

3.3.4 Propriedades mecânicas: .......................................................... 54

3.3.5 Processo de fabricação do tubo: ................................................ 56

3.3.5.1 Tubos soldados com metal de adição - UOE: ............................. 56

3.3.5.1.1 Processo de soldagem SAS:................................................ 58

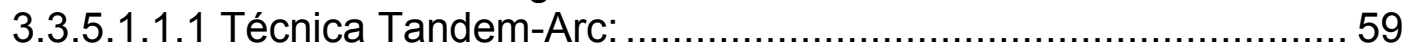

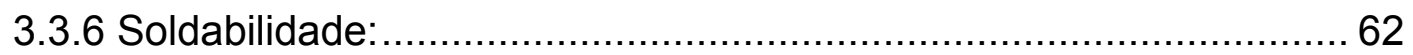

3.3.6.1 Trincas por hidrogênio:......................................................... 64

3.3.6.2 Influência da composição química no comportamento da ZAC

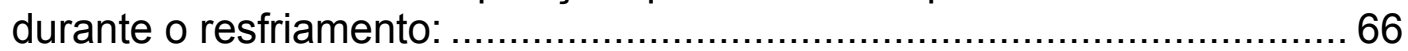

3.3.6.3 Influência da taxa de resfriamento: ............................................ 67

3.3.6.4 Soldabilidade tubo API 5L X80 nacional: ................................... 72

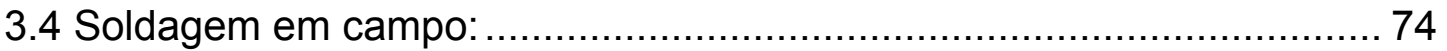

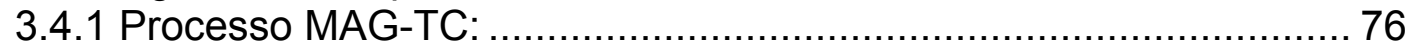

3.4.2 Processo AT:

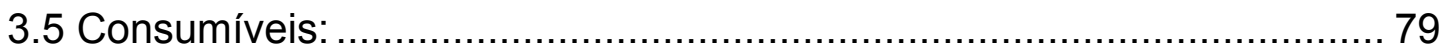

3.6 Qualificação de procedimento de soldagem: ....................................... 81

3.7 Determinação da austenita retida por saturação magnética: ................... 81

3.7.1 Cálculo da fração volumétrica de austenita retida:........................... 83

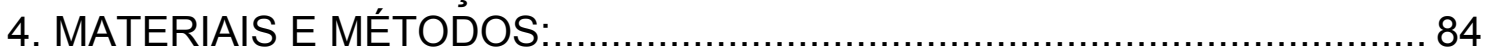

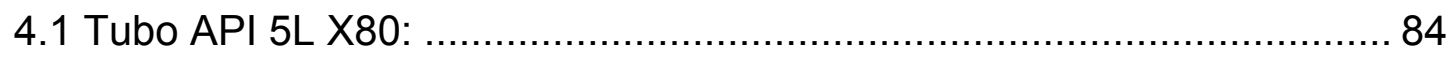

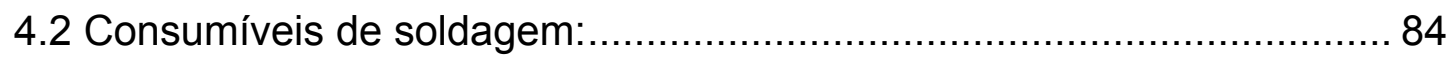

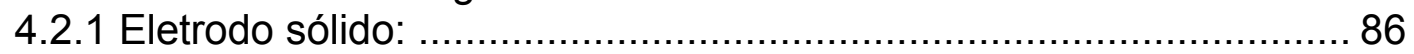

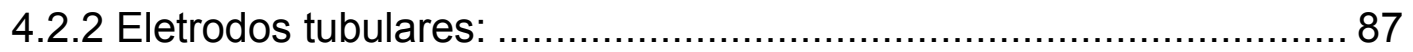

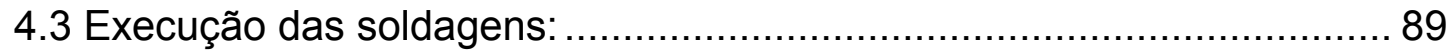

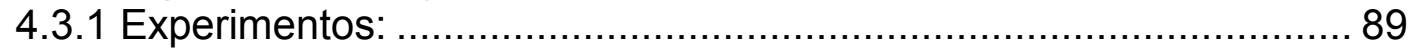

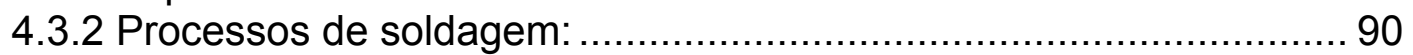

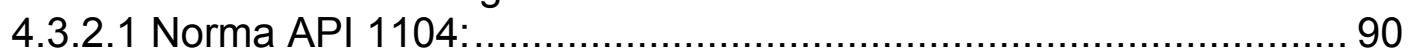

4.3.2.2 Critérios de aceitação:............................................................... 92

4.3.3 Equipamentos de soldagem: .................................................. 93

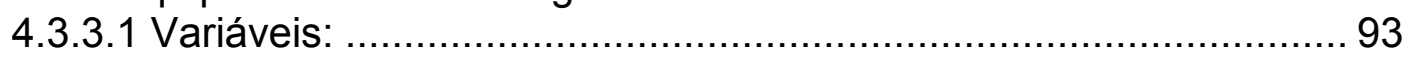

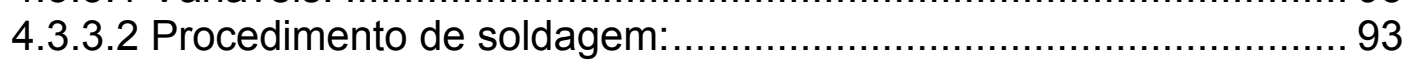


4.3.3.3 Acompanhamento de soldagem:.............................................. 96

4.3.3.4 Medida de Temperaturas ..................................................... 96

4.3.3.5 Controle dos parâmetros de soldagem: ....................................... 96

4.3.3.6 Ensaios não destrutivos: ....................................................... 97

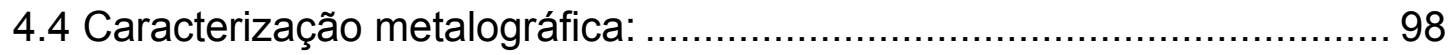

4.4.1 Macrografia: ..................................................................... 98

4.4.2 Microscopia óptica:................................................................ 98

4.4.3 Microscopia eletrônica de varredura - MEV ................................... 99

4.4.4 Microanálise por Dispersão de Energia - EDS …........................... 99

4.4.5 Determinação do agregado MA. ................................................. 99

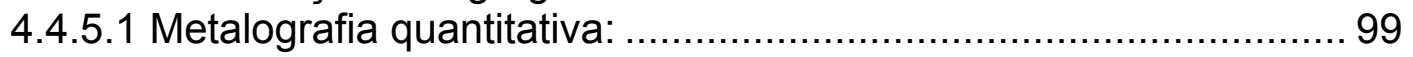

4.4.5.2 Ensaio de saturação magnética: ................................................. 99

4.5 Determinação da composição química: ............................................. 101

4.5.1 Determinação do teor de oxigênio e nitrogênio: ............................ 101

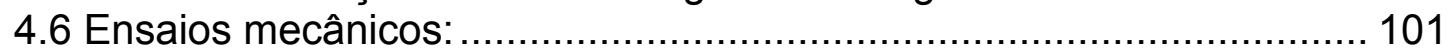

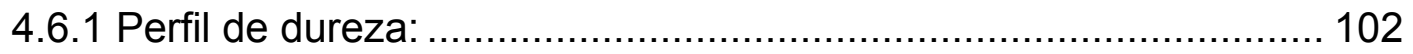

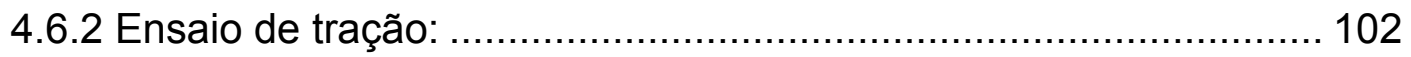

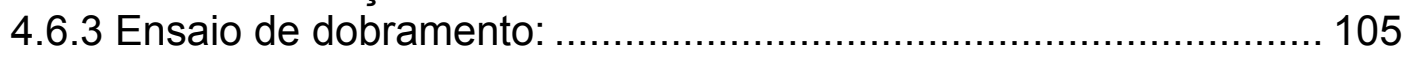

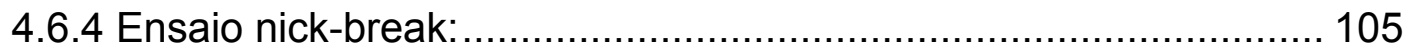

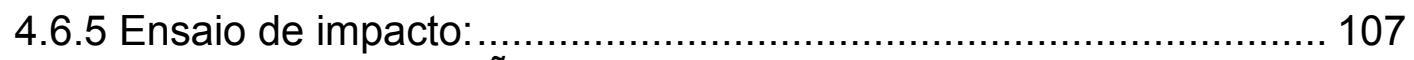

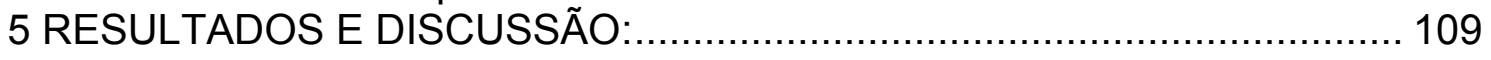

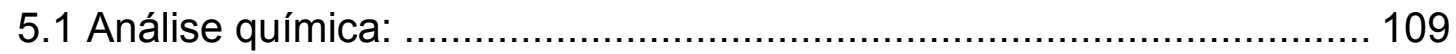

5.1.1 Variação da composição química:............................................... 113

5.1.2 Análise do carbono equivalente: .............................................. 117

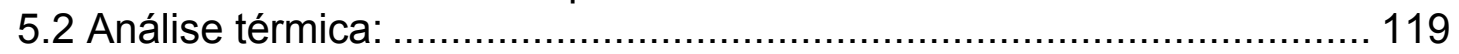

5.2.1 Parâmetros médios de soldagem:.............................................. 119

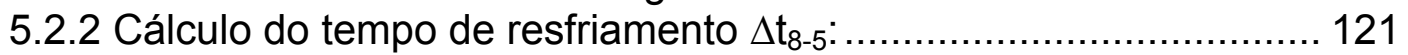

5.2.3 Velocidade de resfriamento:.................................................... 127

5.3 Caracterização metalográfica: ....................................................... 142

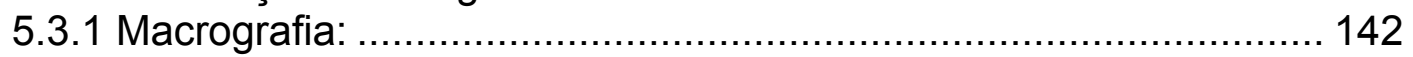

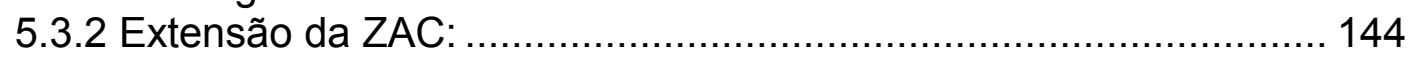

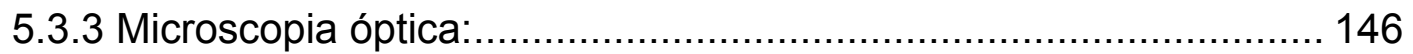

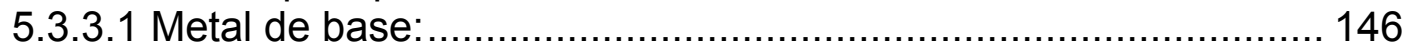

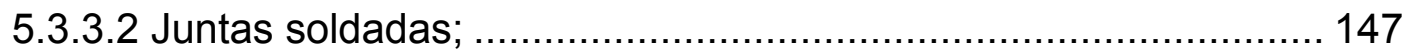

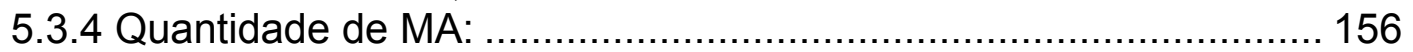

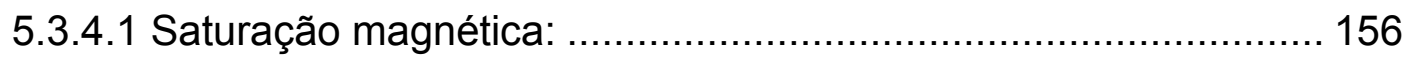

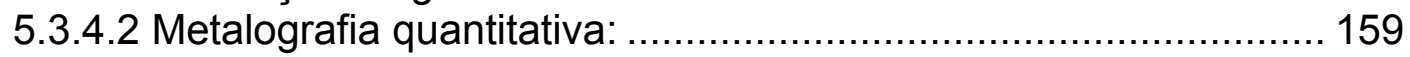

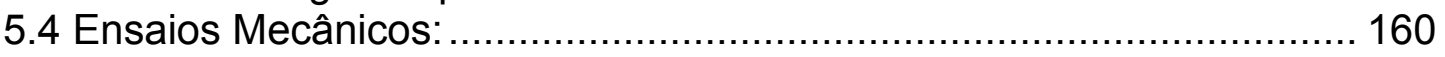

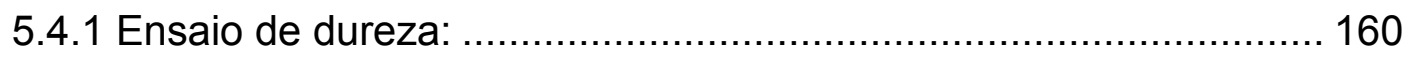

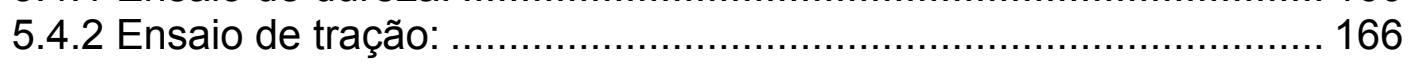

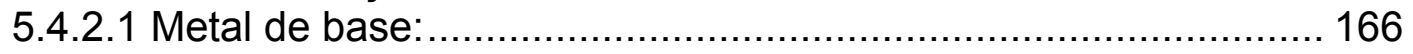

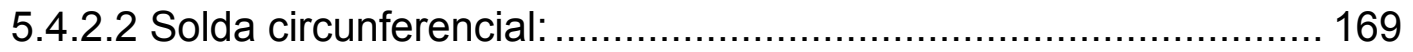

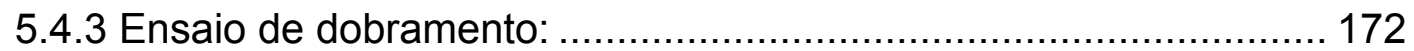

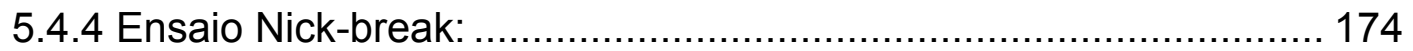

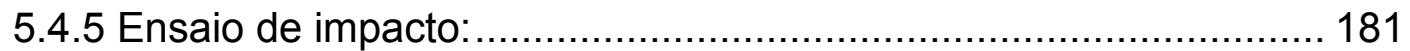

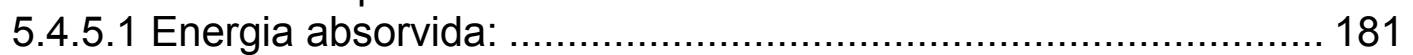

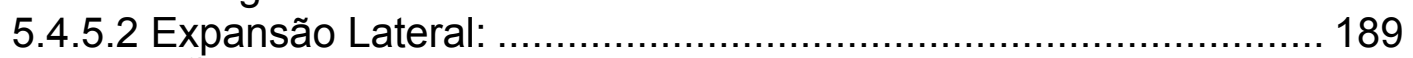

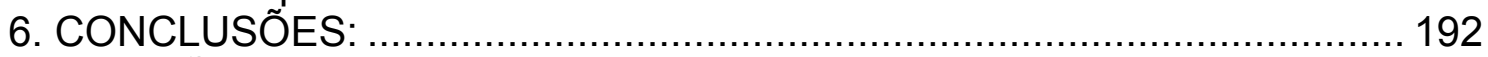

SUGESTÃO DE TRABALHOS FUTUROS:

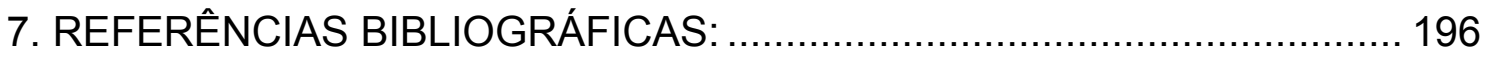




\section{INTRODUCCÃO E JUSTIFICATIVA:}

"Denomina-se soldagem ao processo de união entre duas partes metálicas, usando uma fonte de calor, com ou sem aplicação de pressão. A solda é o resultado deste processo" [1].

Os aços API 5L são utilizados em malhas dutoviárias que são responsáveis pelo transporte de petróleo e seus derivados, desde as regiões produtoras até os centros consumidores. $O$ aumento da demanda energética tem incentivado a ampliação e a construção de novos oleodutos e gasodutos [2].

O transporte por dutos é o modo mais barato de conduzir óleo e gás, porém, deve ser realizado com confiabilidade e segurança operacional para evitar prejuízos econômicos e principalmente ambientais [2].

$\mathrm{Na}$ construção de dutos terrestres são utilizados tubos com elevada resistência mecânica e grandes diâmetros, de modo que durante a operação suportem elevadas pressões. Como exemplo, podem-se citar os aços alta resistência baixa liga - ARBL (ou HSLA - High Strength Low Alloy) API 5L X80, aqui estudado, uma vez que a sua elevada resistência mecânica proporciona uma redução na espessura de parede, resultando não somente em benefícios econômicos como também em maior produtividade durante a construção.

Pode-se resumir deste modo que: quanto menor for a espessura de parede, maior será a economia não somente em relação ao material necessário à fabricação do tubo, mas também em relação aos custos de manuseio, soldagem e instalação; quanto maior for o diâmetro do tubo e a pressão, maior será a quantidade de gás que pode ser transportada [3].

A API (American Petroleum Institute - Instituto Americano do Petróleo) tem especificado a fabricação de tubos, através da norma API 5L "Specification for Line Pipe" [4]. Estes aços são identificados pelo seu limite de escoamento, neste caso da ordem de $80 \mathrm{ksi}$ (552 MPa) para o aço API 5L X80.

$O$ processo de soldagem mais empregado mundialmente para a soldagem de tubos em campo é o processo de soldagem com eletrodo revestido ER (ou SMAW - Shielded Metal Arc Welding) [5], tanto para o passe de raiz, quanto para os passes de enchimento e acabamento. Este processo de 
soldagem apresenta limitações não em relação a sua viabilidade e/ou qualidade da solda produzida (controle metalúrgico), mas em relação à baixa produtividade e aos cuidados necessários ao armazenamento de seus consumíveis, nem sempre realizados com os cuidados devidos.

A fim de que estas limitações inerentes ao processo ER sejam eliminadas, senão diminuídas, está se tornando comum o emprego, em campo, de outros processos de soldagem, ou combinações destes visando um aumento de produtividade, mantendo ou aumentando a qualidade da solda produzida.

Uma das possibilidades de combinações de processos consiste na soldagem do passe de raiz com o processo de soldagem MAG-TC e o enchimento e acabamento com o processo AT (FCAW - Flux Cored Arc Welding) em suas duas variantes: com gás de proteção AT-PG (FCAW-G, Flux Cored Arc Welding - Gas Shielded) e auto-protegido AT-AP (FCAW-S, Flux Cored Arc Welding - Self Shielded).

O processo de soldagem MAG-TC apresenta-se como alternativa na soldagem de passes de raiz, pois apresenta um refinado controle eletrônico da corrente e tensão de soldagem, garantindo assim um bom controle da poça de fusão, boa penetração e baixo aporte de calor. Por ser um processo que utiliza um eletrodo sólido consumível alimentado continuamente, tal como o processo MAG (GMAW Gas Metal Arc Welding), apresenta as mesmas vantagens em termos de produtividade em relação aos outros processos que também utilizam eletrodo de alimentação contínua. Entretanto, tal como o processo MAG necessita de gás de proteção, além de maior habilidade do soldador.

Deste modo, pode-se afirmar que o processo MAG-TC apresenta maior produtividade na soldagem de passe de raiz em tubulações, mas em contrapartida exige mão de obra mais qualificada e treinada, em comparação com o processo ER.

O processo de soldagem AT apresenta-se como alternativa na soldagem dos passes de enchimento e acabamento, pois reúne as vantagens dos processos de alimentação contínua de eletrodo em conjunto com a alta qualidade obtida no metal de solda, além de dispensar o uso e o conseqüente controle de estufas portáteis e os consumíveis nela contidos. Este processo possui duas variantes em relação à proteção da poça de fusão: A primeira 
consiste na aplicação de um gás armazenado em cilindros através da tocha diretamente sobre a poça de fusão, neste caso denominado "gas-shielded (com proteção gasosa)"; A segunda consiste na obtenção deste gás de proteção através da queima do fluxo do eletrodo, denominado "self-shielded" (Autoprotegido) [1].

Deste modo, o processo AT apresenta boa qualidade do metal de solda (controle metalúrgico), tal qual o processo ER, em conjunto com uma maior produtividade na soldagem em campo, especialmente na variante "selfshielded" ou auto-protegido, pois não é necessária a utilização de gás de proteção na poça de fusão (Obtido através da queima do fluxo interno).

A AWS "American Welding Society" é a entidade que possui as especificações de consumíveis de soldagem mais utilizadas no mundo. Os consumíveis para a soldagem de aços alta resistência baixa liga (tubo API $5 \mathrm{~L}$ X80) pelo processo MAG-TC estão especificados na norma AWS A5.28 "Specification For Low-Alloy Steel Electrodes and Rods for Gas Shielded Arc Welding" [6] e os do processo AT estão especificados na norma AWS A5.29 "Specification For Low-Alloy Steel Electrodes For Flux Cored Arc Welding" [7].

A API também especifica o controle de qualidade da soldagem destes tubos através da norma API 1104 "Welding of Pipelines and Related Facilities", a qual contém os requisitos mínimos necessários para a qualificação de um procedimento de soldagem, de modo que se possa garantir que a solda executada entre os tubos atenda aos requisitos de projeto e de que esteja isenta de defeitos que possam comprometer a segurança durante a operação do duto [8].

Dentro deste contexto a soldagem do aço API $5 \mathrm{~L}$ X80 deve ser estudada e desenvolvida, não somente em relação às propriedades e a soldabilidade do aço em si, mas sim em um aspecto mais amplo, englobando entre outros: qualidade, custo, produtividade, viabilidade e facilidade de execução, sempre em atendimento as normas aplicáveis. Isto justifica o estudo da soldabilidade e da viabilidade técnica da soldagem de tubos API $5 \mathrm{~L}$ X80 com a combinação de processos MAG-TC e AT, tanto auto-protegido quanto com proteção gasosa, visando a qualificação de um procedimento de soldagem conforme a norma API 1104. 
Portanto, o presente trabalho será voltado para a avaliação e estudo da soldabilidade e da viabilidade técnica da soldagem do aço API $5 \mathrm{~L}$ X80 nacional comparando-se a combinação dos processos de soldagem MAG-TC e AT em suas duas variantes (auto-protegido e proteção gasosa). Isto posto, serão soldados 2 anéis de tubos API $5 \mathrm{~L} X 80$, sendo: o primeiro com a combinação MAG-TC + AT-AP utilizando os consumíveis ER80S-G e E91T8-G e o segundo com a combinação MAG-TC + AT-PG utilizando os consumíveis ER80S-G e E101T1-GM-H8, visto que estes atendem aos requisitos de composição química e propriedades mecânicas do tubo que está sendo soldado.

As variáveis estudadas serão: a combinação de processos MAG-TC + AT em suas duas variantes, ambos com seus respectivos consumíveis. A geometria do tubo e do chanfro e a temperatura de pré-aquecimento e interpasse serão fixas para os dois anéis soldados, a fim de verificar a influência dos processos e combinações na microestrutura do metal de solda, extensão e características da zona afetada pelo calor (ZAC) e propriedades mecânicas da junta soldada (dureza, resistência a tração, tenacidade) visando não somente a compreensão dos fenômenos metalúrgicos envolvidos, mas também o atendimento aos requisitos mínimos da norma API 1104 para a qualificação de um procedimento de soldagem. 


\section{OBJETIVO:}

Este trabalho tem por objetivo estudar a soldabilidade e a viabilidade técnica da soldagem do aço API $5 \mathrm{~L}$ X80 produzido no Brasil comparando-se a combinação de processos MAG-TC + AT em suas duas variantes (autoprotegido e com proteção gasosa) visando à qualificação de um procedimento de soldagem de acordo com a especificação API 1104. 


\section{REVISÃO BIBLIOGRÁFICA:}

\subsection{Tubos API 5L:}

Os tubos API 5L são fabricados em aço carbono, com ou sem costura e desenvolvidos para condução de gás, água ou derivados de petróleo em indústrias de petróleo e gás natural [9].

A especificação API $5 \mathrm{~L}$ classifica os tubos pelo limite de escoamento, precedido das letras $A, B$ e $X$, sendo que quando precedido pela letra $X$, em maiúsculo, o aço utilizado é de alta resistência. Os tubos podem ser fornecidos em dois níveis de especificação de produto: PSL 1 e 2. A diferença entre estes níveis de especificação consiste no maior rigor em relação aos requisitos técnicos, tais como: carbono equivalente (CE), tenacidade, limite de escoamento e resistência máximos no nível de especificação PSL 2 [9].

Tubos PSL 1 podem ser fornecidos com diâmetro externo variando entre 11,4 mm (0,405") até 2000 mm (80") e os tubos PSL 2 com diâmetro externo entre $115 \mathrm{~mm}(4,5 ")$ até $2000 \mathrm{~mm}$ (80"). O comprimento dos tubos situa-se geralmente em 6 ou 12m [9].

Os tubos podem ser fornecidos com e sem costura. No caso de tubos com costura a soldagem pode ser por processos que utilizam, ou não, metal de adição. No caso de soldagem sem metal de adição o processo de soldagem mais utilizado é o ERW (Electric Resistence Welding). Na soldagem com metal de adição é utilizada a combinação dos processos MAG para o passe de raiz e SAS Tandem-Arc nos passes de enchimento e acabamento, tanto interno quanto externo [10]. O processo de soldagem MAG é utilizado para o passe de raiz com a finalidade de formar um cordão contínuo que será refundido e servirá de suporte para os passes posteriores [11].

Todos os tubos produzidos devem ser aprovados nos Ensaios Não Destrutivos (END) exigidos pela especificação API 5L. Os END’s utilizados para garantir a sanidade do tubo são: visual, teste hidrostático, ultra-som e radiografia. Os Ensaios Destrutivos (ED) de tração e Charpy $V$, além da verificação da composição química, devem ser executados em cada lote de produção [9]. 


\subsection{Aços para Tubos API 5L:}

Antes do desenvolvimento dos aços HSLA, os tubos eram produzidos com aços endurecidos pela adição de carbono e manganês possuindo, desta forma, péssimas soldabilidade e tenacidade [12]. Os aços utilizados na fabricação de tubos API 5L, a partir do grau X42 são do tipo ARBL (HSLA).

\subsubsection{Aços HSLA:}

Aços carbono alta resistência baixa liga ou aços microligados (ARBL ou HSLA em inglês) são aqueles que, através de pequenas adições de elementos de liga, se obtém limite de escoamento acima de 40ksi (276 MPa) na condição laminado, tendo como característica uma boa relação resistência mecânica/tenacidade. Estes aços possuem baixo teor de carbono, garantindo assim boa soldabilidade, quando comparados aos aços carbono convencionais [13].

O desenvolvimento inicial destes aços visou sua utilização na indústria de petróleo e gás, entretanto suas boas propriedades mecânicas estenderam seu uso para outros setores da indústria [14].

A produção dos aços HSLA envolve uma primeira etapa de laminação a quente, onde $\mathrm{o}$ aço obtém a forma do produto final (chapa, placa, perfis estruturais, etc) e em seguida é executada uma segunda etapa de laminação, especialmente com o objetivo de melhorar as propriedades mecânicas [13].

A principal vantagem no uso de aços HSLA é que devido a sua maior resistência mecânica, a espessura de parede dos tubos (para a mesma pressão interna) pode ser diminuída, reduzindo assim o peso e os custos envolvidos no transporte e montagem [5]. Outra possibilidade é manter a espessura de parede do tubo inalterada e elevar a pressão interna (até o limite máximo de $72 \%$ do limite de escoamento do tubo), aumentando o volume de produto transportado $[15,16]$.

Ratnapuli[3] cita que quanto maior for a pressão e o diâmetro interno, maior será a vazão e consequentemente o volume de produto transportado. Valim [17] afirma que a tendência mundial é de que sejam utilizados tubos com 
diâmetro cada vez maior, menor espessura de parede e pressões mais elevadas. Roza[18] afirma que, mantendo-se o diâmetro e pressão constantes, é possível uma redução de $12,5 \%$ na espessura de parede com a utilização de um tubo X80 ao invés de um tubo X70.

\subsubsection{Desenvolvimento:}

No final da década de 40, mais precisamente em 1948, foi introduzida a especificação API 5LX, contendo somente o tubo de grau X42 [19,20]. Em 1959 foi construído nos Estados Unidos o primeiro duto utilizando aço HSLA [15] e neste ano, também houve o desenvolvimento do primeiro aço X52 microligado, possuindo baixo teor de carbono e endurecido pela adição de elementos de microliga, tais como: nióbio e vanádio na ordem de 0,10\% [12].

Durante a década de 60 o aço dominante para gasodutos de alta pressão era o X52 produzido com aço semi-acalmado e sem requisitos de tenacidade, com teor médio de carbono de 0,16\% [15]. Entretanto a necessidade de exploração de petróleo no ártico [21] e a ocorrência de fraturas frágeis com mais de $10 \mathrm{Km}$ de extensão em dutos nos Estados Unidos levaram ao desenvolvimento de tubos produzidos com aços acalmados ao alumínio, proporcionando refino de grão e aumentando a resistência a fratura frágil $[22,23]$.

O teor de carbono dos aços produzidos nesta época situa-se em torno de $0,25 \%$, sendo que hoje em dia o teor foi reduzido para valores em torno de 0,05\%. A redução no teor de carbono melhora substancialmente a soldabilidade do aço, mas em contrapartida aumenta a razão elástica do tubo (LE/LR). O aumento da razão elástica não é desejado, pois diminui a capacidade do material de tolerar deformações plásticas [22].

Também durante a década de 60 tornou-se possível controlar melhor o teor de enxofre presente no aço, sendo que em 1967 o aço X52 possuía teor de enxofre de $0,05 \%$ tornando possível o desenvolvimento de aços específicos para Sour Service (meios que contém mais de $50 \mathrm{ppm}$ de $\mathrm{H}_{2} \mathrm{~S}$ dissolvido). Hoje o teor de enxofre dos aços API situa-se em aproximadamente 0,002\% [22]. 
A tabela 1 mostra a composição química típica dos aços semiacalmados e acalmados de grau médio X52-X60, típicos da década de 60:

Tabela 1: Composição química típica dos aços da década de 60. Baseada na ref. [22].

\begin{tabular}{|c|c|c|c|c|c|c|c|c|c|c|c|c|c|}
\hline Tipo de aço & $\mathrm{C}$ & $\mathrm{Mn}$ & $\mathrm{Si}$ & $\mathrm{S}$ & $\mathrm{P}$ & $\mathrm{Al}$ & $\mathrm{V}$ & $\mathrm{Nb}$ & $\mathrm{Cr}$ & $\mathrm{Mo}$ & $\mathrm{Cu}$ & $\mathrm{Ni}$ & $\mathrm{CE}^{*}$ \\
\hline $\begin{array}{c}\text { Semi- } \\
\text { acalmado } \\
1968\end{array}$ & 0,20 & 0,87 & 0,41 & 0,031 & 0,021 & 0,005 & 0,005 & 0,005 & 0,02 & - & 0,04 & 0,03 & 0,35 \\
\hline $\begin{array}{c}\text { Acalmado } \\
1970\end{array}$ & 0,20 & 1,54 & 0,41 & 0,005 & 0,012 & 0,039 & 0,094 & 0,005 & 0,016 & 0,005 & 0,027 & 0,005 & 0,49 \\
${ }^{*} \mathrm{CE}_{I I W}=$ \\
\hline
\end{tabular}

A rota de produção dos aços API até o final da década de 60 baseava-se na laminação a quente seguido de normalização e já havia sido atingido o grau X60 [5]. Nesta época a exploração de petróleo no ártico levou ao desenvolvimento de aços com maiores requisitos de tenacidade [21]. No início da década de 70 foi obtido um grande avanço com o desenvolvimento de uma nova rota de produção para os tubos API chamada de laminação controlada (Thermomechanical Rolling) ou TMCR (Thermomechanical Controled Rolling). Esta técnica possibilitou o desenvolvimento de aços X70 microligados ao nióbio e vanádio com reduzido tamanho de grão e teor de carbono [5].

Utilizando-se o processo de laminação controlada (TMCR) é possível obter uma microestrutura com tamanho de grão reduzido, com baixo teor de carbono, maior tenacidade e melhor soldabilidade, tendo as propriedades mecânicas iguais ou melhores do que um aço produzido pelo método de laminação a quente e normalização [23]. Os aços produzidos pela rota TMCR possuem um custo menor, devido a não exigência do tratamento térmico de normalização [23].

Com a tecnologia de produção de aços API pela rota TMCR dominada, também foi possível produzir o aço X60 por este processo, com adição de $0,03 \%$ de $\mathrm{Nb}$. O aço X60 obtido desta maneira possui microestrutura perlíticaferrítica de grão refinado e menor teor de carbono. Já o X65 e o X70 são obtidos pela adição de $\mathrm{Nb}$ em conjunto com $\mathrm{V}$, obtendo-se a microestrutura ferrita+perlita [24] com grãos refinados e baixo teor de carbono [20]. 
A tabela 2 apresenta a variação da composição química dos aços X52X60 durante a década de 70 e início da década de 80 produzidos pela rota de laminação controlada.

Tábela 2- Variação da composição química dos aços X52-X60 durante e década de 70 e início de 80 , produzidos pela rota TMCR. Baseada na ref. [22].

\begin{tabular}{|c|c|c|c|}
\hline Elementos & TMCR 1971 & TMCR 1973 & TMCR 1982 \\
\hline $\mathrm{C}$ & 0,16 & 0,12 & 0,06 \\
\hline $\mathrm{Mn}$ & 1,31 & 1,42 & 1,43 \\
\hline $\mathrm{Si}$ & 0,23 & 0,30 & 0,29 \\
\hline $\mathrm{S}$ & 0,012 & 0,011 & 0,003 \\
\hline $\mathrm{P}$ & 0,018 & 0,014 & 0,014 \\
\hline $\mathrm{Al}$ & 0,027 & 0,046 & 0,028 \\
\hline $\mathrm{V}$ & 0,049 & 0,015 & 0,006 \\
\hline $\mathrm{Nb}$ & 0,028 & 0,018 & 0,048 \\
\hline $\mathrm{Cr}$ & 0,035 & 0,016 & 0,019 \\
\hline $\mathrm{Mo}$ & 0,018 & 0,02 & 0,004 \\
\hline $\mathrm{Cu}$ & 0,056 & 0,02 & 0,337 \\
\hline $\mathrm{Ni}$ & 0,027 & 0,040 & 0,221 \\
\hline $\mathrm{CE}$ & 0,40 & 0,37 & 0,34 \\
\hline
\end{tabular}

A tabela 3 mostra a composição química típica de um aço X60, X65 e X70 modernos. Pode-se observar que o teor de carbono é extremamente baixo quando comparado com os apresentados na tabela 1 e 2 :

Tabela 3: Composição química típica dos aços X60, X65 e X70 modernos. Ref. [20,15].

\begin{tabular}{|c|c|c|c|c|c|c|c|c|c|c|c|c|}
\hline Grau & $\% \mathrm{C}$ & $\% \mathrm{Si}$ & $\% \mathrm{Mn}$ & $\% \mathrm{P}$ & $\% \mathrm{~S}$ & $\% \mathrm{Ni}$ & $\% \mathrm{Nb}$ & $\% \mathrm{~V}$ & $\% \mathrm{Ti}$ & $\% \mathrm{~B}$ & $\% \mathrm{Cr}$ & $\% \mathrm{Ni}$ \\
\hline X60 & 0,02 & 0,14 & 1,59 & 0,018 & 0,03 & - & 0,04 & - & 0,017 & 0,001 & - & - \\
\hline X65 & 0,03 & 0,16 & 1,61 & 0,016 & 0,03 & 0,17 & 0,05 & - & 0,016 & 0,001 & - & - \\
\hline X70 & 0,104 & 0,33 & 1,76 & - & - & 0,04 & 0,041 & 0,092 & 0,007 & - & 0,04 & 0,04 \\
\hline
\end{tabular}

Baseado nestes fatos, o aço grau $X 70$ tornou-se o padrão mundial na construção de dutos, desde a década de 80 até os dias atuais [23, 15], sendo que o primeiro duto utilizando tubos X70 foi construído na Alemanha ainda na década de 70 [16]. Entretanto, o futuro aponta para a diminuição de seu uso em favor do X80 [15]. 


\subsubsection{Estágio Atual:}

No começo da década de 80 foi introduzido um melhoramento na técnica TMCR chamado de resfriamento acelerado (Accelerated Cooling), que consiste em resfriar o material rapidamente após a etapa final de laminação, de $800{ }^{\circ} \mathrm{C}$ a $500^{\circ} \mathrm{C}$. Após atingir esta temperatura o resfriamento é feito ao ar para que haja a formação de bainita. Esta técnica que reúne o processo de laminação controlada seguido de resfriamento acelerado é denominada TMCP (Thermomechanical Controled Process) [4]. Utilizando-se desta técnica é possível obter uma microestrutura com grão refinado, reunindo alta resistência mecânica e tenacidade. [25] A taxa de resfriamento utilizada depende da composição química, espessura da chapa e das propriedades mecânicas requeridas para o material [26]. A taxa média de resfriamento utilizada é de 15 a $20^{\circ} \mathrm{C} / \mathrm{s}$ [23].

Por este método é possível produzir o aço grau X80 com a adição de nióbio e titânio em conjunto com teor reduzido de carbono, mesmo sem a adição de elevados teores de elementos de liga caros, tais como; níquel e molibdênio, proporcionando desta maneira, excelente soldabilidade [5]. A microestrutura presente no aço X80 é predominantemente bainítica, a qual possui a excelente combinação de tenacidade e resistência mecânica [15].

É possível a obtenção de aços da classe X80 sem a utilização do método TMCP (resfriamento acelerado), utilizando-se o método TMCR. Neste caso, a classe X80 é obtida pela adição de uma maior quantidade de elementos de liga, tais como níquel e molibdênio nos aços ligados originalmente ao nióbio e vanádio, seguido de um refinado processo de laminação [18, 20,27]. Este foi o caminho adotado pela indústria nacional, devido a limitações operacionais. Esta maior quantidade de elementos de liga é prejudicial, pois afeta a soldabilidade, já que esta é influenciada pelo valor do carbono equivalente e pela microestrutura resultante [28].

A primeira aplicação de aço X80 em dutos se deu em 1985 na Alemanha, quando trechos de tubos $\mathrm{X} 80$ foram instalados em um duto de $\mathrm{X} 70$ somando um total de $3,2 \mathrm{Km}$, mantendo os níveis de esforços compatíveis com o restante do duto em X70. Em 1986, na Tchecoslováquia também foram instalados trechos de tubo $\mathrm{X} 80$ em um duto construído com aço X70, 
totalizando 1,6 Km e diâmetro de 56" (1422,4 mm). Em 1990 no Canadá foi instalado um duto com aço X80 com comprimento de $50 \mathrm{Km}$ e diâmetro de 42".(1066,8 mm) Após sete anos, em 1992, foi construído o primeiro duto inteiramente projetado para explorar as propriedades do aço X80, ligando Schlüchtern a Werne na Alemanha com comprimento de 260 Km e 48" (1219,2 $\mathrm{mm}$ ) de diâmetro. Em 1994 foi completado outro duto de aço X80 construído no Canadá, tendo $54 \mathrm{Km}$ de extensão e diâmetro de 48" (1219,2 mm) [5]. Em 2005 foi construído nos Estados Unidos o maior duto utilizando tubos X80 do mundo, com extensão de 650 km e 36" (914,4 mm) de diâmetro [15]. A tabela 4 mostra a composição química dos aços X80 utilizados na Alemanha e Canadá.

Tabela 4-Composição química dos aços utilizados na Alemanha e Canadá. Baseado na ref. [5].

\begin{tabular}{|c|c|c|c|}
\hline Elementos & Alemanha 1992 48" & Canadá1990 42" & Canadá 1994 48" \\
\hline $\mathrm{C}$ & 0,09 & 0,06 & 0,04 \\
\hline $\mathrm{Si}$ & 0,04 & 0,3 & 0,35 \\
\hline $\mathrm{Mn}$ & 1,91 & 1,81 & 1,77 \\
\hline $\mathrm{P}$ & 0,016 & 0,008 & 0,014 \\
\hline $\mathrm{S}$ & 0,0009 & 0,003 & 0,005 \\
\hline $\mathrm{Cu}$ & 0,04 & 0,16 & 0,38 \\
\hline $\mathrm{Cr}$ & 0,05 & 0,02 & 0,06 \\
\hline $\mathrm{Ni}$ & 0,04 & 0,09 & 0,15 \\
\hline $\mathrm{Mo}$ & 0,01 & 0,18 & 0,26 \\
\hline $\mathrm{V}$ & - & 0,08 & - \\
\hline $\mathrm{Nb}$ & 0,042 & 0,03 & 0,09 \\
\hline $\mathrm{Ti}$ & 0,018 & 0,01 & 0,03 \\
\hline $\mathrm{Al}$ & 0,036 & 0,026 & 0,032 \\
\hline $\mathrm{N}$ & 0,0035 & - & - \\
\hline $\mathrm{B}$ & 0,003 & - & - \\
\hline $\mathrm{CE}$ & 0,43 & - & - \\
\hline
\end{tabular}

Os aços X80 modernos produzidos pelo método TMCP são ligados principalmente ao $\mathrm{Nb}$ e $\mathrm{Cr}(0,08$ a 0,10\% e 0,30\%, respectivamente), possuindo teor de carbono de $0,04 \%$ e estabilizados ao titânio. Titânio é adicionado para combater o efeito maléfico do nitrogênio, melhorando a tenacidade. Por possuir teor de carbono baixo a resistência mecânica é obtida com a adição de nióbio e 
cromo, sendo que o último atua na formação de bainita. O nióbio propicia intenso refino de grão e aumenta a temperatura de recristalização, permitindo assim a laminação em temperatura mais alta. Este conceito é conhecido como HTP (High Temperature Processing). A laminação do aço termina entre 860 a $820^{\circ} \mathrm{C}$ (exigindo menor carga de laminação), e após é aplicado o resfriamento acelerado para a formação de bainita [15].

Existem outras combinações de liga que podem ser utilizadas na obtenção de aços X80, tais como: nióbio e molibdênio (NbMo); nióbio, cromo e molibdênio (NbCrMo) [29]. A escolha da combinação utilizada para a produção do aço depende de vários fatores, tais como, custo dos elementos, disponibilidade, desempenho da liga, método e rota de produção e capacidade de processamento da usina produtora.

A composição $\mathrm{NbCr}$ é atualmente preferida, pois o aço é laminado em temperatura mais alta $\left(860-820^{\circ} \mathrm{C}\right.$, ao invés de $750-700^{\circ} \mathrm{C}$ do $\left.\mathrm{TMCR}\right)$, diminuindo a carga de laminação e por não utilizar elementos de liga caros, tais como, vanádio e molibdênio [15]. A tabela 5 mostra a composição química dos aços X80 produzidos atualmente com diversos sistemas de liga e rotas de produção.

Um dos benefícios da utilização de aços com elevada resistência mecânica é a redução de custos devido à menor espessura de parede (para a mesma pressão interna) e consequentemente a menor quantidade de material necessário para a fabricação do tubo. Bai [5] cita que é possível obter uma economia de $7,5 \%$ entre custos diretos e indiretos em um projeto de duto de 42" (1066,8 mm) com a substituição do tubo X65 por X80, pois apesar de custar $10 \%$ a mais por tonelada, o custo por metro é $6 \%$ mais barato.

Em relação à soldagem, Bai [5] afirma ainda que uma menor espessura de parede é desejável, pois permite reduzir o tempo de exposição necessário para a gamagrafia das juntas soldadas, a quantidade de consumíveis utilizados e o tempo de soldagem de cada junta, proporcionando deste modo, maior produtividade com conseqüente redução no custo de locação das fontes de soldagem (quando aplicável) e mão de obra, entre outros. 
Tabela 5. Composição química típica dos aços X80 produzidos atualmente.

\begin{tabular}{|c|c|c|c|c|c|c|c|}
\hline Elemento & $A$ & $B$ & C & $\mathrm{D}$ & $E$ & $F$ & G \\
\hline C & 0,08 & 0,04 & 0,03 & 0,04 & 0,07 & 0,08 & $\leq 0,22$ \\
\hline $\mathrm{Mn}$ & 1,70 & 1,58 & 1,68 & 1,86 & 1,76 & 1,59 & $\leq 1,85$ \\
\hline $\mathrm{Si}$ & 0,35 & 0,13 & 0,27 & 0,19 & 0,18 & 0,35 & NE \\
\hline$S$ & 0,005 & - & - & 0,005 & 0,05 & 0,002 & 0,015 \\
\hline $\mathrm{P}$ & 0,018 & - & - & 0,02 & 0,02 & 0,016 & 0,025 \\
\hline $\mathrm{Cu}$ & 0,40 & 0,20 & 0,30 & 0,01 & 0,01 & - & $\mathrm{NE}$ \\
\hline $\mathrm{Nb}$ & 0,11 & 0,098 & 0,095 & 0,075 & 0,071 & \multirow{3}{*}{0,131} & \multirow{3}{*}{$\leq 0,15$} \\
\hline V & 0,08 & - & - & 0,005 & 0,005 & & \\
\hline $\mathrm{Ti}$ & 0,025 & 0,011 & 0,019 & 0,017 & 0,014 & & \\
\hline $\mathrm{Al}$ & 0,050 & - & - & 0,03 & 0,03 & 0,03 & $\mathrm{NE}$ \\
\hline $\mathrm{N}$ & 0,008 & 0,004 & 0,010 & 0,005 & 0,006 & 0,006 & $\mathrm{NE}$ \\
\hline $\mathrm{Cr}$ & 0,40 & 0,24 & 0,03 & 0,33 & 0,20 & \multirow[b]{2}{*}{0,36} & $\mathrm{NE}$ \\
\hline Mo & 0,35 & - & 0,30 & 0,03 & 0,16 & & $\mathrm{NE}$ \\
\hline $\mathrm{Ni}$ & 1,00 & 0,10 & 0,12 & 0,002 & 0,002 & - & $\mathrm{NE}$ \\
\hline$B$ & 0,0005 & - & - & - & - & - & $\mathrm{NE}$ \\
\hline $\mathrm{Ca}$ & 0,0045 & - & - & - & - & - & $\mathrm{NE}$ \\
\hline $\mathrm{Pcm}$ & 0,23 & 0,15 & - & 0,16 & 0,18 & 0,18 & $\mathrm{NE}$ \\
\hline CE & 0,45 & - & - & - & - & - & $\mathrm{NE}$ \\
\hline
\end{tabular}

A. Composição ideal recomendada pela EWI Microalloying. Produzido pela rota TMCP. ref. [12].

B. Aço $\mathrm{Nb}-\mathrm{Cr}$ produzido pela rota TMCP e utilizado pela ref. $[29,15]$.

C. Aço Nb-Mo produzido pela rota TMCP e utilizado pela ref. $[29,15]$.

D. Aço Nb-Cr produzido pela rota TMCR e utilizado pela ref. [27].

E. Aço Nb-Cr-Mo produzido pela rota TMCR utilizado pela ref. [27].

F. Aço Nb-Cr-Mo produzido pela rota TMCR utilizado pela ref. [18]

G. Composição química especificada pela norma API 5L X80 ref. [9]].

As desvantagens do uso de aços com maior resistência mecânica residem no fato de que mundialmente são poucos os fabricantes que dominam a tecnologia de produção destes aços, e os riscos potenciais (soldagem, corrosão, reparos, etc) envolvidos na construção de um duto com aço ainda não suficientemente consagrado.

A figura 1 apresenta a variação entre o custo do aço por tonelada e o custo do tubo por metro, em relação à resistência mecânica. 


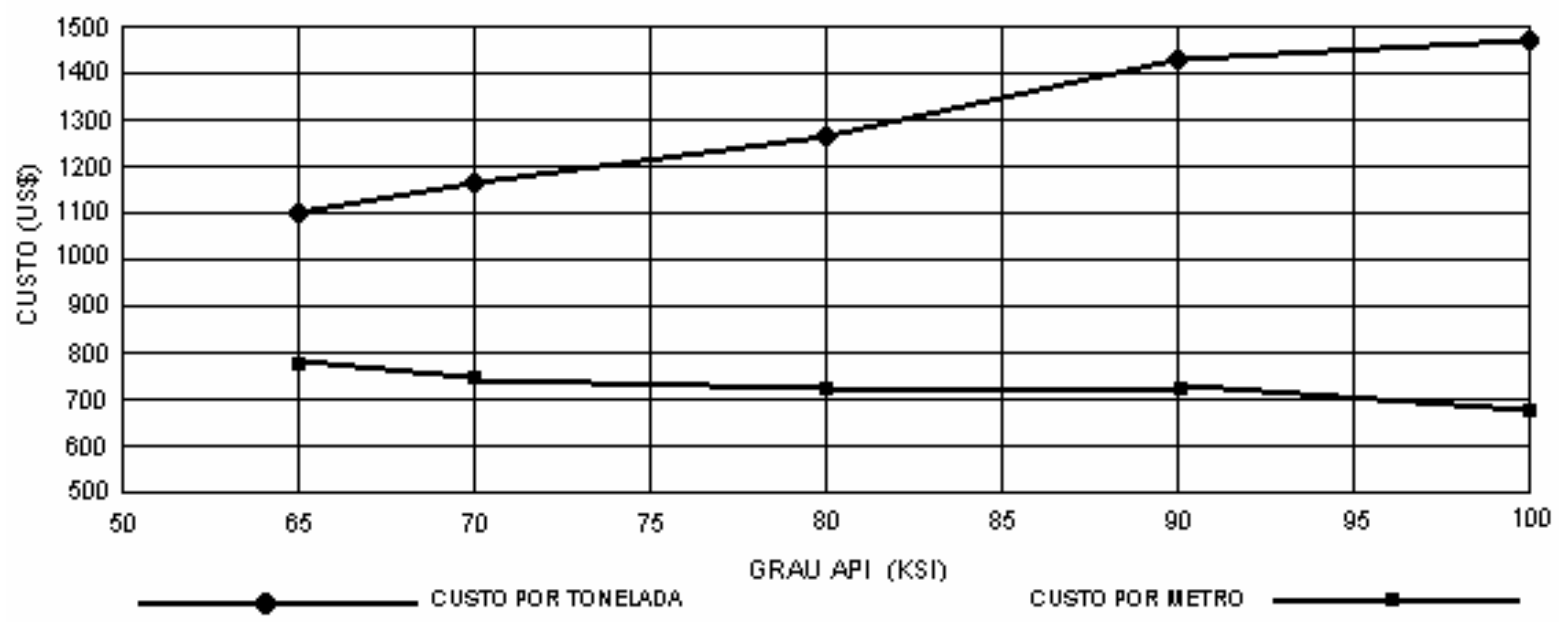

Figura 1 Gráfico custo/resistência mecânica de aços para tubos API 5L [5].

\subsubsection{Tendências:}

A tendência mundial aponta para o desenvolvimento de novas classes de aços de ultra-alta resistência mecânica, tais como X100 e X120.

As classes X100 e X120 podem ser obtidas pela adição de maior quantidade de elementos de liga, tais como; cromo, níquel, cobre, boro e molibdênio no atual sistema de liga dos aços X80 obtidos pela rota de produção TMCP, pelo aumento da taxa de resfriamento ou uma combinação destes [5,22].

Quando do emprego de taxas de resfriamento elevadas na etapa de resfriamento acelerado, da ordem de $35^{\circ} \mathrm{C} / \mathrm{s}$, ocorre diretamente a têmpera do aço proporcionando desta forma maior resistência mecânica.

Empregando-se taxas de resfriamento da ordem de $20^{\circ} \mathrm{C} / \mathrm{s}$, e temperatura de término de resfriamento de 500 a $550^{\circ} \mathrm{C}$, a microestrutura consiste totalmente de bainita. Quando do emprego de taxas de resfriamento de $35^{\circ} \mathrm{C} / \mathrm{s}$ e temperatura de término de resfriamento de $200^{\circ} \mathrm{C}$, isto é, abaixo da temperatura de formação de martensita, promove a formação de uma microestrutura final com grãos refinados de bainita com ilhas de martensita, obtendo as propriedades mecânicas para a classificação X100 em conjunto com parâmetro de carbono equivalente (Pcm) em torno de 0,19 (dependendo da composição química), proporcionando boa soldabilidade [23]. 
A microestrutura dos aços X120 também consiste de bainita de granulação fina. Devido à alta densidade de discordâncias e diminuto tamanho de grão, a microestrutura bainítica reúne alta tenacidade em conjunto com alta resistência mecânica, sendo assim a microestrutura desejada para os aços empregados na fabricação de tubos alta resistência [30].

A composição química dos aços X100 e X120 deve ser cuidadosamente determinada, a fim de não obter teor de carbono equivalente elevado. $O$ sistema de liga básico dos aços X120 consiste de CuNiCrMo microligados ao NbVTiB.

Dentre os elementos utilizados no sistema de liga dos aços X100 e X120, o boro é um eficiente elemento de liga (multiplicado por 5 na fórmula do parâmetro do carbono equivalente $\mathrm{P}_{\mathrm{cm}}$ ) com custo reduzido e de difícil controle. Quando de sua utilização o teor de carbono não deve exceder $0,04 \%$ de modo a prevenir dureza elevada na linha de segregação central [22].

Nestes aços deve-se diminuir o valor do carbono equivalente a fim de proporcionar boa soldabilidade e tenacidade. Esta é a principal razão do uso preferencial de resfriamento acelerado com taxa de resfriamento incrementada ao invés da simples adição de elementos de liga. O aumento na taxa de resfriamento é mais eficaz na redução do tamanho de grão do que a adição de elementos de liga [22].

A elevada resistência mecânica dos aços X100 e X120 proporciona maior dificuldade de conformação dos tubos, necessitando o desenvolvimento de maquinário apropriado [30].

Em relação à soldagem longitudinal do tubo, os consumíveis empregados devem possuir composição química tal que proporcione a resistência mecânica necessária em conjunto com alta tenacidade. Devido ao processo SAS empregado, a energia de soldagem empregada precisa ser controlada cuidadosamente, a fim de não prejudicar as propriedades mecânicas da ZAC. Uma forma de controlar a perda das propriedades mecânicas consiste na adição de $\mathrm{V}$ ao metal de base de forma a promover endurecimento por precipitação [30].

A figura 2 representa o desenvolvimento dos aços API $5 \mathrm{~L}$ desde a década de 50 e a figura 3 mostra o desenvolvimento em conjunto com os principais elementos de liga. 


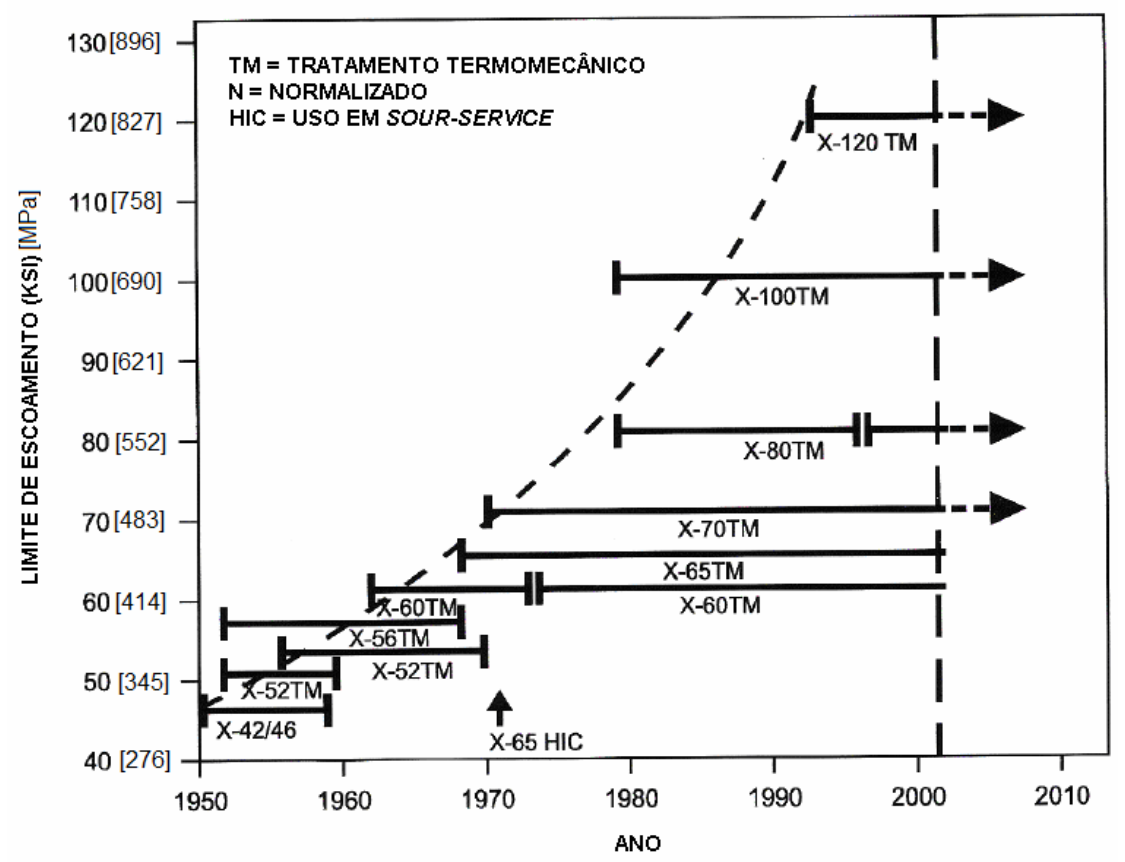

Figura 2 - Desenvolvimento dos aços API 5L desde a década de 50. Baseado na ref. [12].

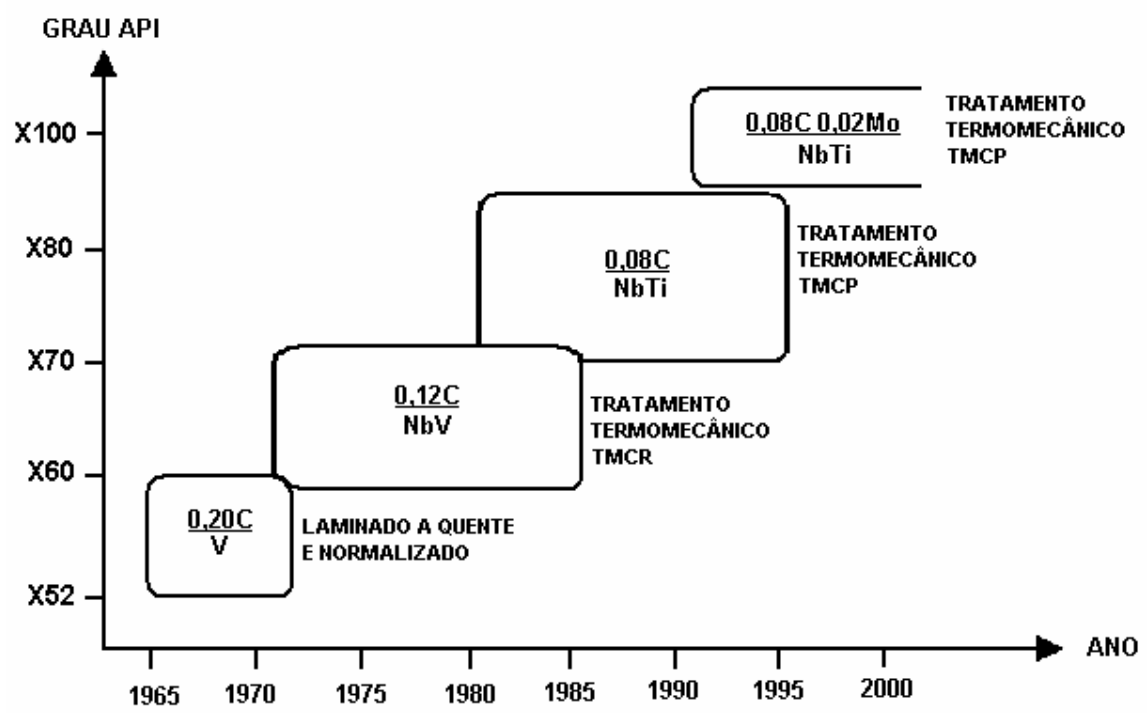

Figura 3 - Desenvolvimento dos aços API 5L, elementos de liga e rota de produção. Baseado na ref. [5].

A especificação API 5L [9] em sua $42^{a}$ edição contempla somente até o grau X80. Entretanto os graus X100 e X120 devem ser especificados nas próximas revisões da norma. 
A tabela 6 apresenta a composição química dos aços X100 e X120 experimentais utilizados pelas referências $[23,30]$ e a tabela 7 apresenta as propriedades mecânicas.

Tabela 6 - Composição química dos aços X 100 e X120 experimentais utilizados pelas ref. $[23,30]$.

\begin{tabular}{|c|c|c|c|c|c|c|c|c|c|c|}
\hline Grau & $\mathrm{C}$ & $\mathrm{Si}$ & $\mathrm{Mn}$ & $\mathrm{Ni}$ & $\mathrm{Mo}$ & $\mathrm{Nb}$ & $\mathrm{Ti}$ & $\mathrm{Cu}$ & $\mathrm{N}$ & $\mathrm{Pcm}$ \\
\hline $\mathrm{X} 100$ & 0,07 & 0,20 & 1,90 & 0,20 & 0,30 & 0,05 & 0,015 & 0,20 & - & - \\
\hline $\mathrm{X} 120$ & 0,06 & 0,23 & 1,91 & - & - & 0,042 & 0,017 & - & 0,004 & 0,23 \\
\hline
\end{tabular}

Tabela 7- Propriedades mecânicas dos aços X100 e X120 experimentais utilizados pelas ref. $[23,30]$.

\begin{tabular}{|c|c|c|c|}
\hline Grau & LE & LR & LE/LR \\
\hline X100 & $107 \mathrm{ksi}(690 \mathrm{MPa})$ & $115 \mathrm{ksi}(793 \mathrm{MPa})$ & 0,93 \\
\hline X120 & $120 \mathrm{ksi}(827 \mathrm{MPa})$ & $135 \mathrm{ksi}(931 \mathrm{MPa})$ & 0,88 \\
\hline
\end{tabular}

No caso do Brasil, o desenvolvimento e a fabricação de aços com graus X100 e X120 dependem da implantação do método de resfriamento acelerado, o que também beneficiaria também o aperfeiçoamento da fabricação de aços X80.

\subsection{Aço API 5L X80 Nacional:}

Em 1986, a Cosipa iniciou os estudos para o desenvolvimento do aço API 5L X80 no Brasil. Estas chapas foram produzidas por laminação controlada (TMCR) a partir de duas ligas: NbVCrNi e NbMoTi. Ambas possuíam adição de cálcio para fins de controle da morfologia de inclusões. A microestrutura de ambas consistia de ferrita alongada com ilhas de MA (Martensita-Austenita) e carbono equivalente de aproximadamente 0,20\% [31]. A composição química de ambas as ligas é apresentada na tabela 8. 
Tabela 8- Composição química do primeiro aço X80 desenvolvido no Brasil. Ref. [31].

\begin{tabular}{|c|c|c|c|c|c|c|c|c|c|c|c|c|}
\hline Liga & $\mathrm{C}$ & $\mathrm{Mn}$ & $\mathrm{Si}$ & $\mathrm{Al}$ & $\mathrm{Nb}$ & $\mathrm{V}$ & $\mathrm{Cr}$ & $\mathrm{Ni}$ & $\mathrm{Mo}$ & $\mathrm{Ti}$ & $\mathrm{N}$ & $\mathrm{Pcm}$ \\
\hline $\mathrm{NbVCrNi}$ & 0,09 & 1,56 & 0,37 & 0,022 & 0,044 & 0,066 & 0,20 & 0,22 & - & - & 0,007 & 0,20 \\
\hline $\mathrm{NbMoTi}$ & 0,08 & 1,53 & 0,21 & 0,026 & 0,026 & - & - & - & 0,34 & 0,016 & 0,004 & 0,19 \\
\hline
\end{tabular}

Atualmente, o aço para tubo API $5 \mathrm{~L}$ X80 produzido no Brasil pela Usiminas utiliza a rota de produção TMCR [28]. Apresenta microestrutura com morfologia acicular com predominância de bainita, possuindo baixo teor de carbono e microligado ao nióbio, vanádio e titânio. Os elementos cromo e o molibdênio são adicionados com a finalidade de formar bainita, manter o teor de carbono e manganês em níveis baixos e prevenir a formação da linha de segregação central. Para fins de desoxidação silício e alumínio são adicionados. Cálcio é adicionado para promover a globulização de inclusões $[18,3]$.

\subsubsection{Rota de Produção:}

A rota de produção deste aço é via laminação controlada sem resfriamento acelerado (TMCR). Isto exige um grande ajuste e controle da composição química e da etapa de laminação, a fim de que sejam obtidas as propriedades mecânicas necessárias para o grau X80. Deste modo, é necessário a adição de uma maior quantidade de elementos de liga para prover a temperabilidade e o retardamento na temperatura de transformação $\gamma \rightarrow \alpha, a$ fim de obter a microestrutura desejada [37].

Segundo Roza [18], o aço API 5L X80 é elaborado em conversores LD onde ocorre a redução do teor de carbono e fósforo. Após esta etapa é executada a dessulfurização, desoxidação com a adição de silício e alumínio e adição de elementos de liga. Em seguida cálcio é adicionado para globulizar as inclusões.

A solidificação é realizada através de lingotamento contínuo, de onde são obtidas placas que serão laminadas até a espessura da chapa que será utilizada na fabricação do tubo [18]. A primeira etapa de laminação é responsável pela grande redução da espessura e obtenção da forma final do produto [13]. 
Em seguida as placas são aquecidas até a temperatura de solubilização do nióbio e vanádio (adicionados com a intenção de formar precipitados finos e dispersos pela matriz ferrítica), permanecendo nesta temperatura o tempo necessário. A presença de titânio impede que ocorra o crescimento de grão austenítico, possibilitando posteriormente a transformação da austenita em finos grãos ferríticos [18].

Após esta etapa é executada a laminação de desbaste com a quantidade mínima de passes necessários para obter a largura e a espessura requerida para a etapa final de laminação. Em seguida são aplicados jatos de água com alta pressão a fim de controlar a temperatura da chapa e remover as carepas de óxido que poderão comprometer a qualidade superficial do produto acabado [18].

A etapa final de laminação é executada em temperatura abaixo da temperatura de não-recristalização (750 a $700{ }^{\circ} \mathrm{C}$ [15]), na qual seja possível obter grande deformação, formando uma microestrutura de granulação fina (em forma de grãos alongados ou "panquecas" [20]) que irá proporcionar grande resistência mecânica e tenacidade. O controle da espessura é feito de forma automática, a fim de garantir pequena variação durante a laminação em toda a extensão da chapa [18]. A figura 4 apresenta uma ilustração do ciclo de laminação controlada com as possíveis etapas de resfriamento.

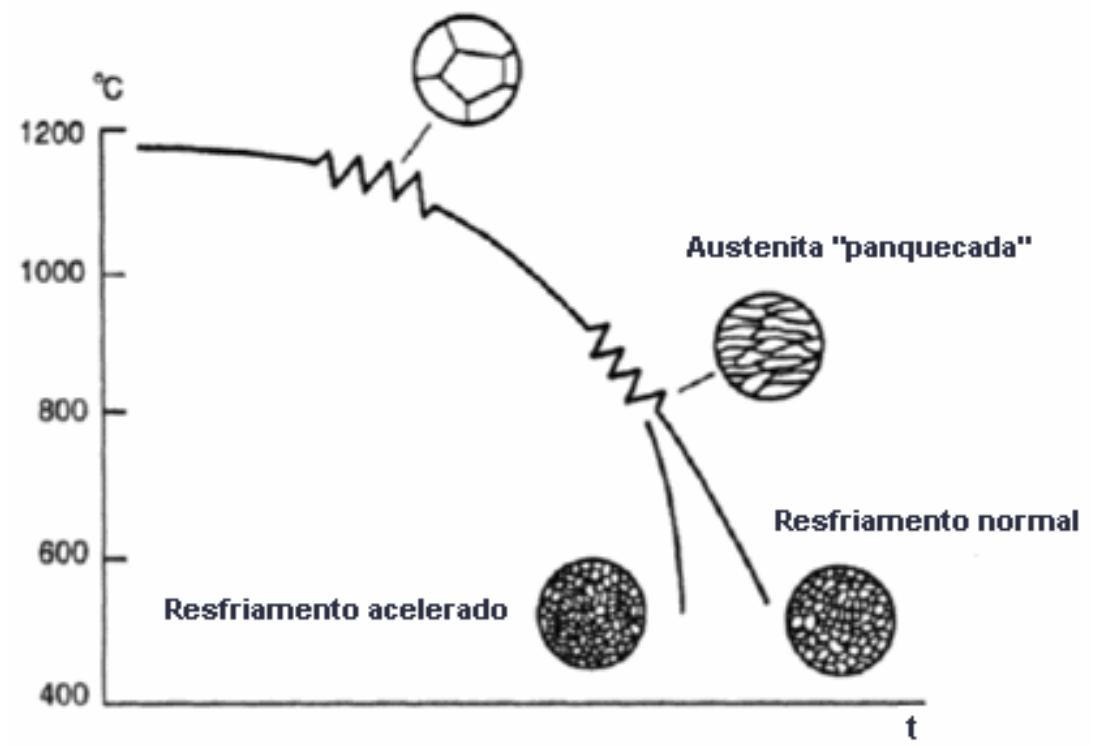

Figura 4-Ciclo de laminação controlada, apresentando o tempo de espera entre as etapas de laminação e as etapas de refrigeração possíveis [20]. 
Após o término da etapa de laminação a chapa é resfriada com jatos de água regulados automaticamente até atingir a temperatura abaixo de $600^{\circ} \mathrm{C}$, obtendo uma quantidade significante de bainita [18].

Bott [27] e Roza [18] demonstraram que é possível a obtenção de aço para tubos API $5 \mathrm{~L}$ grau $\mathrm{X} 80$ através da rota de laminação controlada sem resfriamento acelerado (TMCR).

\subsubsection{Microestrutura:}

O projeto de liga do aço API $5 \mathrm{~L}$ X80 deve proporcionar uma microestrutura que combine alta resistência mecânica e tenacidade em conjunto com um baixo nível de segregações e inclusões não metálicas [18]. Deste modo devem ser levados em consideração os seguintes fatores no projeto de liga dos aços API de um modo geral [3]:

- Qualidade do produto metalúrgico (mínimo de segregações, defeitos);

- Propriedades mecânicas desejadas;

- Conformabilidade a frio e a quente;

- Soldabilidade;

- Aplicação;

- Custo.

A microestrutura do aço $\mathrm{X} 80$ produzido no Brasil, com teor de carbono entre 0,04 a $0,08 \%$ e manganês entre 1,59 a $1,86 \%$, microligado ao vanádio, nióbio e titânio, e com adições de cromo e molibdênio apresenta microestrutura bainítica (65\%) [27,18], ferrita primária e pequena quantidade de MA (Martensita-Austenita) [18]. O ajuste da composição química auxilia a etapa de laminação controlada a obter a microestrutura bainítica. As figuras 5 e 6 apresentam as micrografias obtidas por microscopia eletrônica de varredura (MEV) dos aços utilizados por Roza [18] e Bott [27]. 


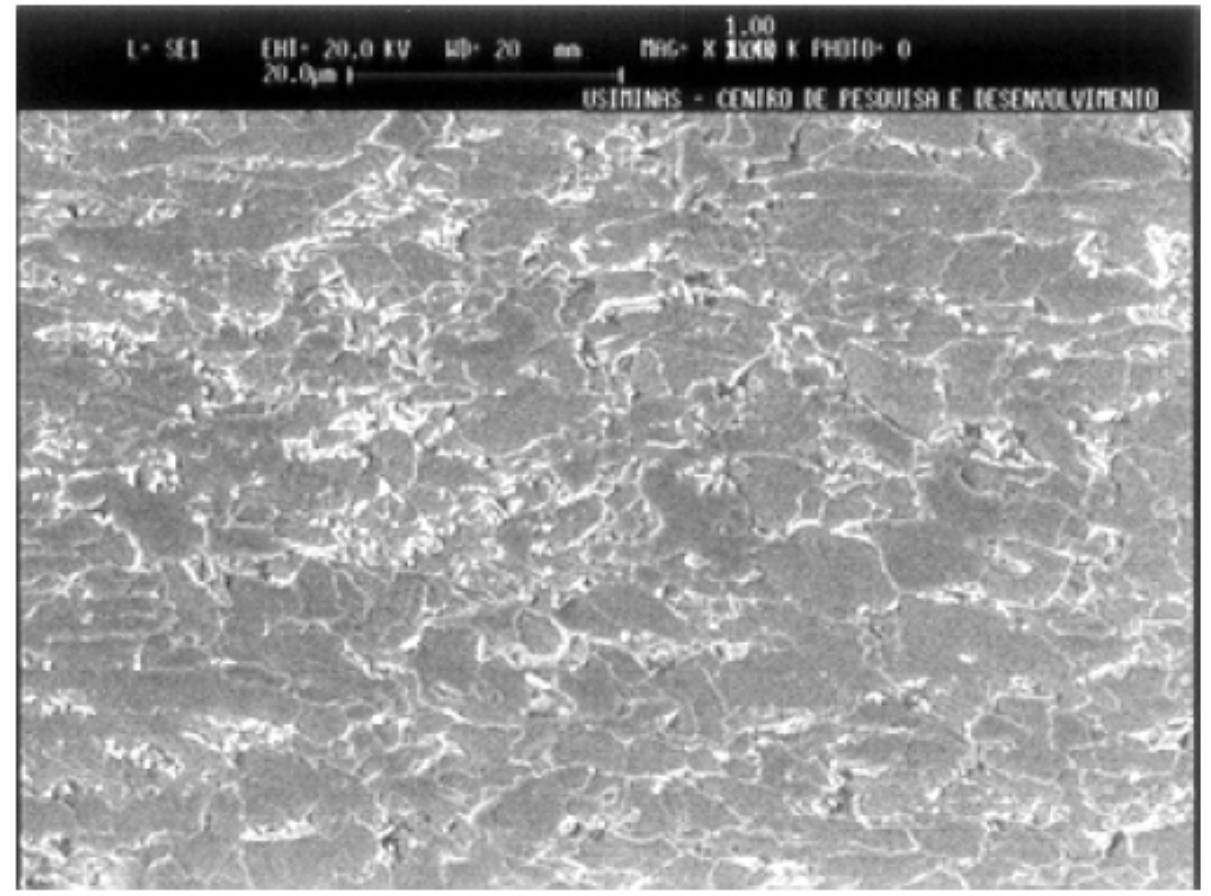

Figura 5- Micrografia do aço utilizado pela ref. [18], mostrando os diferentes microconstituintes. Ampliação 1000x.

Segundo Bott [27] a microestrutura bainítica é desejável, pois apresenta alta resistência mecânica e tenacidade. Esta microestrutura pode ser obtida pela adição de elementos de liga, tais como molibdênio, manganês e níquel.

Bott [27] cita ainda que a excelente combinação resistência mecânicatenacidade exibida pelo aço X80 pode ser degradada devido ao ciclo térmico imposto pela etapa de soldagem, podendo ainda ocasionar regiões frágeis na ZAC. A presença e a morfologia (alongada) do MA (Martensita-Austenita) estão relacionadas com esta perda de tenacidade. De modo que esta situação seja contornada, outros fatores devem ser considerados, tais como: teor de carbono do MA (Martensita-Austenita) maior que $0,05 \%$, fração volumétrica, tamanho e distribuição.

Inclusões alongadas de MnS (sulfeto de manganês) prejudicam a tenacidade do aço [12]. Roza [18] cita que não foram encontrados inclusões alongadas de $\mathrm{MnS}$, o que demonstra que o tratamento de globulização foi adequado. 


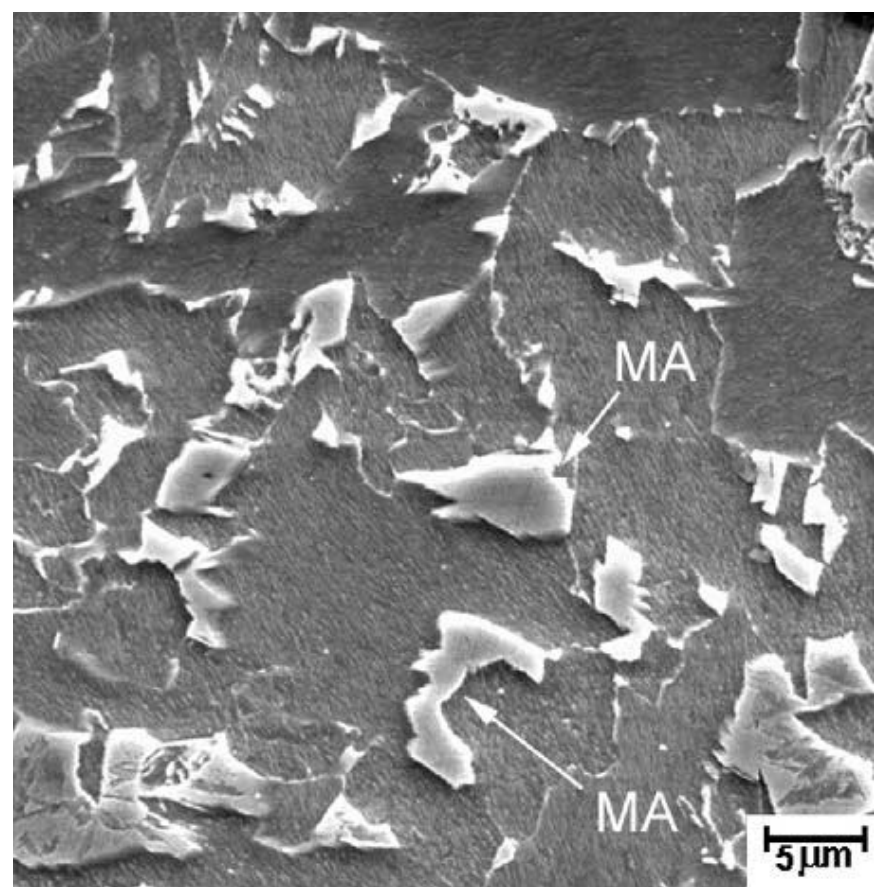

(a)

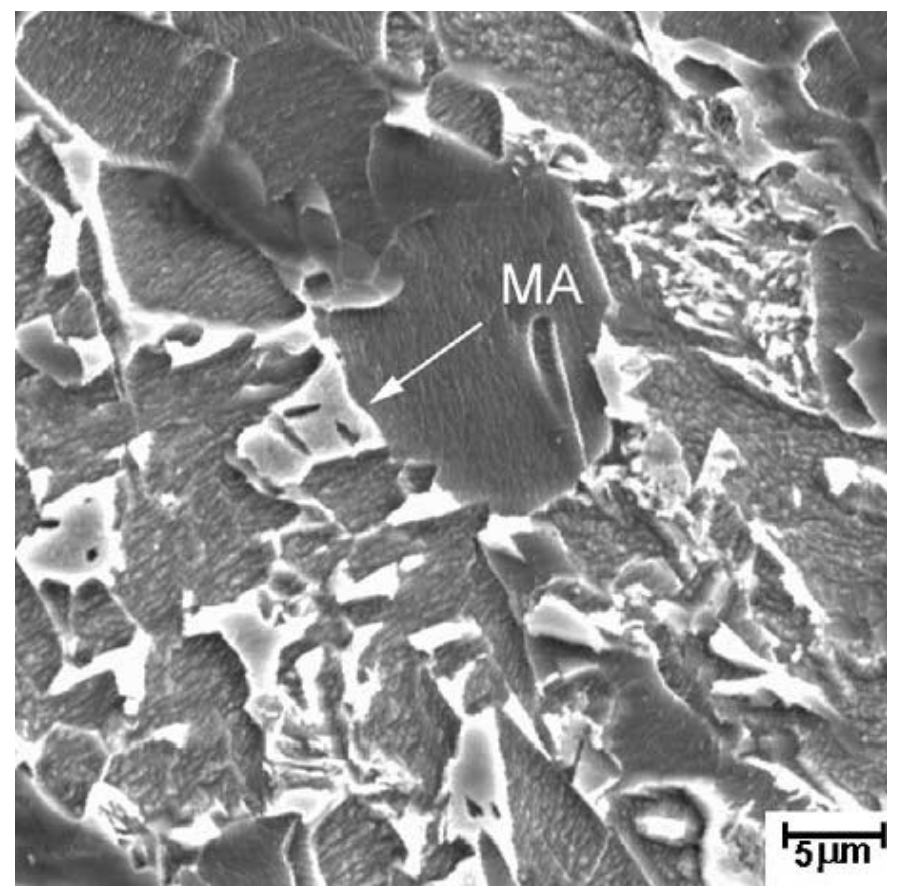

(b)

Figura 6- Micrografia dos aços utilizados pela ref. [27], mostrando as ilhas de MA (Martensita-Austenita) em matriz ferrítica. (a) Aço ligado ao NbCrMo (b) Aço ligado ao $\mathrm{NbCr}$. 


\subsubsection{Composição química:}

Gray e Pontremoli apud Silva [31], afirma que existem cerca de 50 a 60 opções metalúrgicas para a obtenção de aços API $5 \mathrm{~L}$ grau X70 ou X80, relacionadas com a composição química e a etapa de laminação. A figura 7 apresenta algumas das possibilidades para a obtenção de aços com microestrutura ferrita acicular.

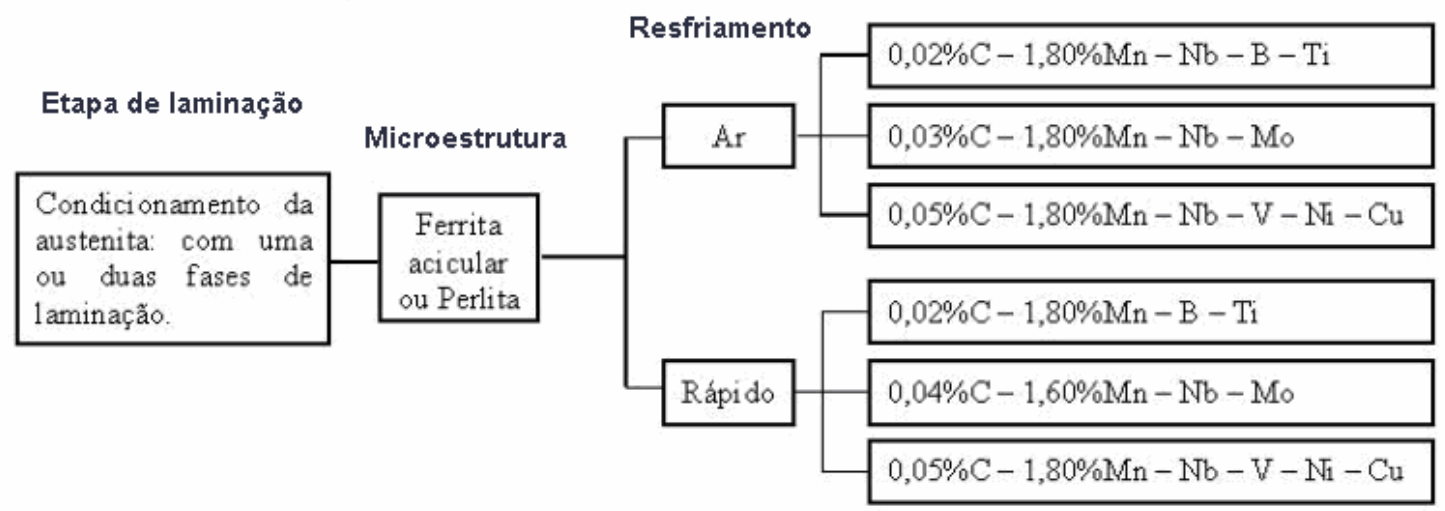

Figura 7- Algumas das opções metalúrgicas de obtenção de aços API 5L X80. Figura baseada na ref. [31].

De um modo geral, a composição química dos aços API 5L pode ser caracterizada por [3]:

- Aços acalmados ao silício e ao alumínio;

- Combinação baixo carbono (0,10\% máx) e alto manganês (2,0 máx);

- Elementos de liga: $\mathrm{Ni}, \mathrm{Cu}, \mathrm{Cr}, \mathrm{Mo}$;

- Elementos de microliga: $\mathrm{Nb}, \mathrm{V}, \mathrm{Ti}(\Sigma 0,15 \%$ máx $)$

A adição de elementos de liga diminui a temperatura de transformação austenita-ferrita $(\gamma \rightarrow \alpha)$ e aumenta a taxa de endurecimento por solução sólida. Os elementos de microliga são adicionados com a finalidade de auxiliar no refino de grão e endurecimento por precipitação [3].

O principal elemento dos aços API 5L é o carbono, entretanto teores acima de $0,10 \%$ são evitados, pois diminuem a ductilidade e tenacidade e aumentam a probabilidade de defeitos superficiais, a ocorrência de micro- 
segregação durante a solidificação, a quantidade de perlita, o limite de resistência e valor do carbono equivalente [3].

Kushida et al. apud Roza [18], cita que adições complementares de cromo e molibdênio são utilizadas a fim de diminuir o teor de carbono e manganês necessários para atingir a resistência mecânica necessária, evitando assim a possibilidade de formação de linha de segregação central.

Bott [27] estudou dois sistemas de ligas de aço API 5L X80, uma baseada na liga $\mathrm{NbCrMo} \mathrm{e} \mathrm{outra} \mathrm{na} \mathrm{liga} \mathrm{NbCr}$, avaliando a microestrutura obtida com relação as propriedades mecânicas, a soldabilidade e a resistência a corrosão. Foi verificado que ambas as ligas atendem aos requisitos da norma API 5L e apresentam boa soldabilidade. Siciliano [29] afirma que é preferível a utilização da liga $\mathrm{NbCr}$, pois esta não utiliza Mo diminuindo o custo final.

A tabela 9 mostra as diversas composições químicas dos aços API $5 \mathrm{~L}$ X80 fabricados no Brasil utilizados por diversos autores, bem como o exigido pela API 5L [9].

\subsubsection{Efeito dos principais elementos de liga:}

Segundo Ratnapuli [3], o carbono é o principal elemento de liga dos aços API 5L. A tendência mundial aponta para a diminuição do teor de carbono no aço, diminuindo o valor de CE e, consequentemente, a temperabilidade, a fim de que seja garantida a boa soldabilidade do aço [27].

O manganês atua como inibidor de produtos de transformação como a ferrita poligonal e a perlita, e aumenta a resistência mecânica da ferrita por solução sólida. Outro efeito do manganês é a eliminação da fragilidade a quente devido a formação de MnS [12].

O alumínio é adicionado com a finalidade de atuar como agente desoxidante e de refino de grão. Quando presente em solução sólida (teores acima de $0,015 \%$ ) garante que quando o aço for aquecido durante as operações de soldagem ou tratamento térmico, o tamanho de grão austenítico será reduzido [12]. Em conjunto com nitrogênio forma precipitados de nitretos que proporcionarão refino de grão [27]. 
O silício atua moderadamente como agente de endurecimento por solução sólida. Entretanto, sua função principal é atuar como desoxidante e estabilizador da ferrita [12]. Pode-se considerar que quando o teor de silício é superior a $0,1 \%$, o aço é totalmente acalmado (desoxidado) e abaixo de $0,1 \%$, semi-acalmado (semi-desoxidado) [22].

Tabela 9: Composição química do aço API 5L X80 nacional estudado por diversos autores.

\begin{tabular}{|c|c|c|c|c|c|c|c|c|c|c|}
\hline Elemento & 1 & 2 & 3 & 4 & 5 & 6 & 7 & 8 & 9 & 10 \\
\hline$C$ & 0,04 & 0,07 & 0,08 & 0,04 & 0,04 & 0,05 & 0,068 & 0,056 & 0,065 & 0,072 \\
\hline $\mathrm{Mn}$ & 1,86 & 1,76 & 1,59 & 1,86 & 1,75 & 1,76 & 1,83 & 1,77 & 1,87 & 1,84 \\
\hline $\mathrm{Si}$ & 0,19 & 0,18 & 0,35 & 0,19 & 0,17 & 0,17 & 0,193 & 0,223 & 0,165 & 0,153 \\
\hline$S$ & 0,005 & 0,05 & 0,002 & 0,006 & 0,004 & 0,002 & - & 0,0029 & 0,004 & 0,007 \\
\hline$P$ & 0,02 & 0,02 & 0,016 & 0,018 & 0,019 & 0,016 & 0,0019 & 0,0150 & 0,018 & 0,018 \\
\hline $\mathrm{Cu}$ & 0,01 & 0,01 & - & 0,02 & 0,01 & 0,02 & 0,0115 & 0,099 & 0,012 & 0,013 \\
\hline $\mathrm{Nb}$ & 0,075 & 0,071 & \multirow{3}{*}{0,131} & 0,075 & 0,073 & 0,066 & 0,064 & 0,068 & 0,07 & 0,061 \\
\hline V & 0,005 & 0,005 & & 0,006 & 0,005 & 0,025 & 0,0263 & 0,020 & 0,022 & 0,02 \\
\hline $\mathrm{Ti}$ & 0,017 & 0,014 & & 0,017 & 0,013 & 0,016 & 0,0137 & 0,018 & 0,012 & 0,014 \\
\hline $\mathrm{Al}$ & 0,03 & 0,03 & 0,03 & 0,032 & 0,032 & 0,035 & 0,024 & 0,034 & 0,040 & 0,003 \\
\hline $\mathrm{N}$ & 0,005 & 0,006 & 0,006 & - & 0,0035 & 0,0057 & - & 0,030 & - & - \\
\hline $\mathrm{Cr}$ & 0,33 & 0,20 & \multirow[b]{2}{*}{0,36} & 0,33 & 0,21 & 0,15 & 0,189 & 0,134 & 0,181 & 0,171 \\
\hline Mo & 0,03 & 0,16 & & 0,03 & 0,16 & 0,20 & 0,245 & 0,256 & 0,20 & 0,20 \\
\hline $\mathrm{Ni}$ & 0,002 & 0,002 & - & 0,02 & 0,02 & 0,02 & 0,0165 & 0,012 & 0,018 & 0,025 \\
\hline$B$ & - & - & - & - & 0,0002 & 0,0003 & - & 0,0005 & 0,0009 & 0,0008 \\
\hline $\mathrm{Ca}$ & - & - & - & - & 0,0014 & 0,003 & - & 0,0027 & 0,0034 & - \\
\hline $\mathrm{Pcm}$ & 0,16 & 0,18 & 0,18 & 0,16 & 0,16 & 0,17 & 0,13 & 0,18 & 0,19 & 0,20 \\
\hline CE & - & - & - & 0,43 & - & 0,42 & - & 0,20 & - & \\
\hline
\end{tabular}

1 X80 liga NbCr utilizado por Bott e Valim ref. [27,17].

2 X80 liga NbCrMo utilizado por Bott e Valim ref. [27,17].

3 X80 utilizado por Roza ref. [18].

4 X80 utilizado por Ferreira ref. [11].

5 X80 utilizado por Silva e Ordoñez ref. [32,4].

6 X80 utilizado por Zacca ref. [33].

7 X80 utilizado por Ramirez ref. [26].

8 X80 utilizado por Caloi ref. [34].

$9 \times 80$ utilizado por Pinto ref. [35].

10 X80 utilizado por Durant ref. $[36,37]$. 


\subsubsection{Efeito dos elementos de microliga:}

O nióbio, quando adicionado ao aço em teor adequado, promove o aumento da resistência mecânica e tenacidade. Este efeito é proporcionado pelo refino do grão austenítico e ferrítico e pela precipitação de $\mathrm{NbC}$ (carboneto de nióbio) após a laminação [12]. Quando presente em aços com baixo teor de carbono em conjunto com laminação controlada, tende a transformar a austenita em ferrita poligonal, ferrita acicular ou bainita com excelente tenacidade. Atualmente o teor médio de nióbio varia entre 0,10 a $0,11 \%$, dependendo do teor de carbono, roteiro de laminação e carga de elementos de liga [12]. Na década de 60 o uso do nióbio como elemento de liga foi preterido por causa da formação da ferrita de Widmanstätten devido ao alto teor de carbono presente nos aços daquela época [12].

O vanádio também proporciona aumento de resistência mecânica pela precipitação de carbonetos e nitretos. A eficácia do vanádio, como agente de refino de grão em processos que utilizam laminação controlada, é diminuída devido ao seu menor potencial de precipitação durante a laminação e por não retardar efetivamente a recuperação e recristalização do grão austenítico. Quando tenacidade à fratura é requerida, é comum a adição de vanádio em conjunto com 0,02 a 0,03\% de nióbio. A eficiência é diminuída quando o teor de carbono é baixo e quando titânio está presente na liga, pois a tendência de formação de carbonetos e nitretos de vanádio é menor do que a de nitretos de titânio. O teor médio de vanádio varia entre 0,015 a $0,10 \%$ [12]. A figura 8 apresenta a influência do titânio, nióbio, alumínio e vanádio na temperatura de término de recristalização em um aço com 0,07\%C, 1,40\%Mn e 0,25\%Si.

O titânio é um forte formador de nitretos. O teor de titânio recomendado para se obter boa tenacidade na ZAC e diminuir a tendência de trincas transversais durante o lingotamento contínuo é de 0,008 a 0,015\% em aços contendo 0,004 a $0,008 \%$ de nitrogênio. Com o aumento no teor de nitrogênio ou titânio, há a tendência de formação de cubos de nitreto de titânio (TiN, visíveis por microscopia ótica), prejudicando a tenacidade da ZAC. Um teor maior que 0,03 a $0,08 \%$ tende a formar carboneto de titânio (TiC), o qual proporciona um grande aumento na resistência mecânica, mas reduz a tenacidade. Os nitretos formados com tamanho entre 5 a $20 \mathrm{~nm}$ auxiliam no 
refino de grão durante a laminação e soldagem, enquanto que os de maior tamanho tendem a nuclear trincas e reduzir a tenacidade. [12]. A figura 9 ilustra a influência do nitrogênio em relação ao teor de titânio na energia absorvida no ensaio de impacto Charpy V.

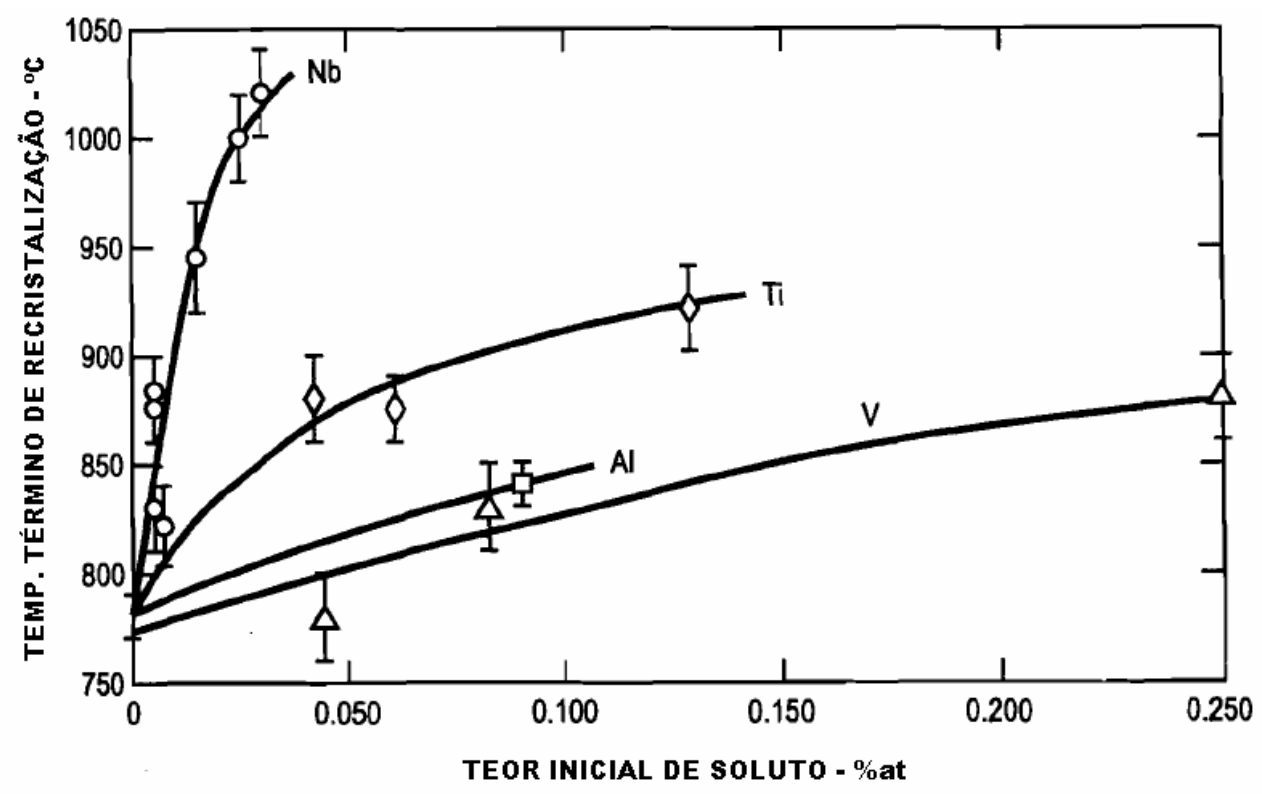

Figura 8- Influência dos elementos $\mathrm{Ti}, \mathrm{Nb}, \mathrm{Al}$ e $\mathrm{V}$ na temperatura de término de recristalização em um aço contendo $0,07 \% \mathrm{C}, 1,40 \% \mathrm{Mn}$ e $0,25 \%$ Si. ref. [12].

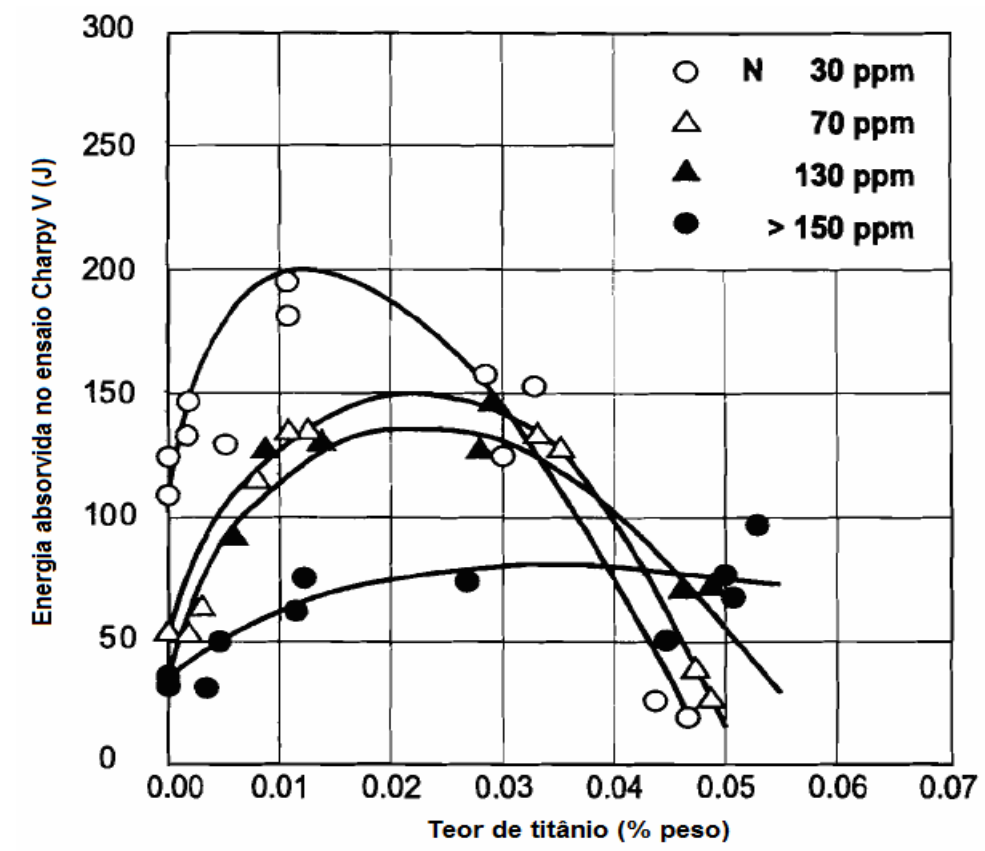

Figura 9 - Influência do nitrogênio em relação ao teor de titânio na energia absorvida no ensaio de impacto Charpy.ref. [12]. 


\subsubsection{Efeito dos elementos convencionais de liga:}

O molibdênio é utilizado freqüentemente com o nióbio em aços para tubos $\mathrm{X} 70$ e X80. O molibdênio em conjunto com o nióbio produz o carboneto $(\mathrm{NbMo})_{4} \mathrm{C}_{3}$, que propicia a formação de ferrita acicular ou bainita, desde que o teor de molibdênio seja superior a $0,12 \%$ e a taxa de resfriamento seja adequada. A formação deste composto, em relação ao carboneto de nióbio puro, aumenta o volume de precipitados e melhora o benefício do nióbio. Teor de molibdênio maior que $0,12 \%$ proporciona aumento de resistência mecânica por solução sólida [12]. A tendência mundial aponta para a diminuição do uso de molibdênio, devido ao seu alto custo [29].

O cromo é utilizado sozinho ou em conjunto com $0,15 \%$ de níquel ou $0,12 \%$ de molibdênio, a fim de se obter uma pequena quantidade de MA (Martensita-Austenita). O aumento de resistência mecânica com a adição de cromo é obtido pela formação de ilhas de MA (Martensita-Austenita) e pela formação de ferrita acicular ou bainita, neste caso, em conjunto com resfriamento acelerado. [12]

Em aços específicos para utilização "sour-service", o cromo, ao contrário do manganês, níquel e cobre, não reduz a faixa de temperatura da ferrita $\delta$. Deste modo, o aço permanece maior tempo nesta faixa, permitindo uma maior taxa de difusão dos solutos na microestrutura, proporcionando a redistribuição das segregações pela microestrutura. Neste caso, a linha de segregação formada possui dureza menor, melhorando a resistência a trincas por hidrogênio. [12]

Outra vantagem da utilização do cromo nestes em aços (sour-service), em relação ao molibdênio, reside no fato de que o cromo não afeta o benefício da adição de cobre (redução da taxa de corrosão em ambientes sour-service). A adição de cromo também auxilia na redução do efeito Bauschinger durante a fabricação do tubo [12].

A figura 10 apresenta o teor e o efeito dos elementos de liga em relação à faixa de temperatura de ocorrência de ferrita $\delta$ na tendência de formação de linha central de segregações. 


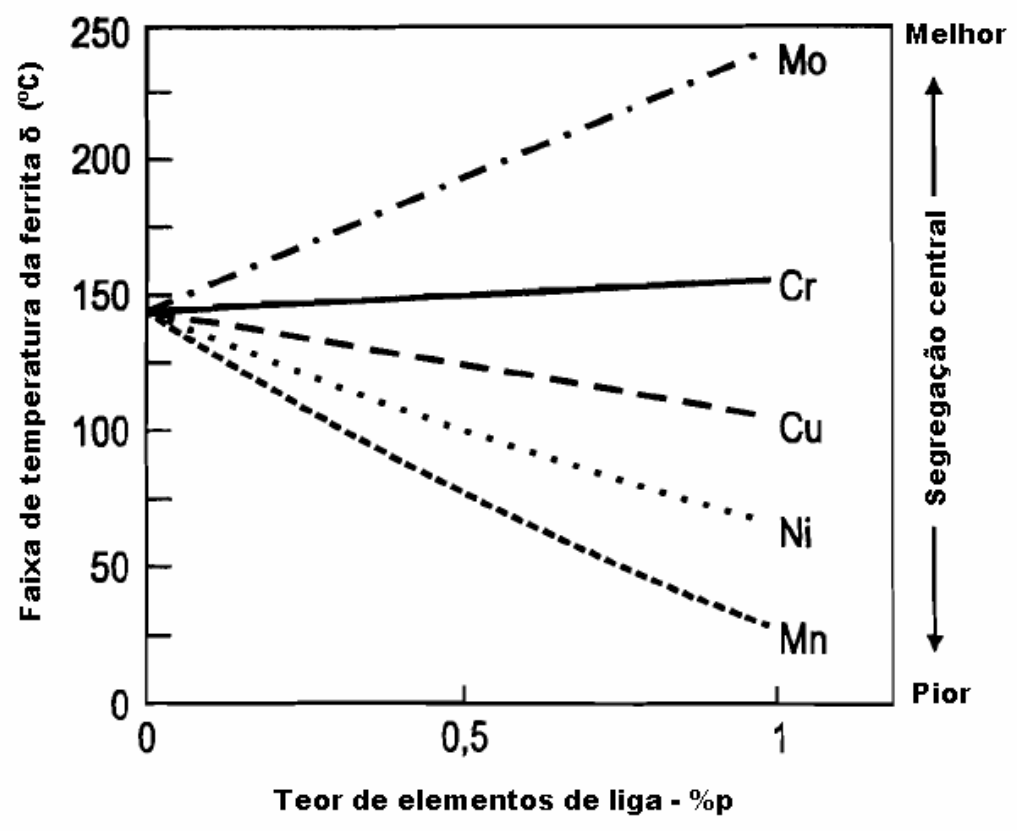

Figura 10 - Teor e efeito dos elementos de liga em relação à faixa de temperatura da ferrita $\delta$ na tendência de formação de linha central de segregação. ref. [12].

O níquel é adicionado com a finalidade de aumentar a tenacidade. Atua também como agente de aumento de resistência mecânica, não possuindo neste caso, efeito eficaz. Quando há a presença de níquel na liga em conjunto com cobre, o níquel atua na prevenção da fragilidade a quente promovida pelo cobre. Quando utilizado em conjunto com o cromo, o níquel promove a formação do microconstituinte MA (Martensita-Austenita) [12].

O cobre quando presente na liga provém da utilização de sucata na obtenção do aço ou é adicionado intencionalmente em ligas específicas para sour-service. A adição de cobre ocasiona fragilidade a quente durante a laminação. Esta condição desenvolve-se pelo enriquecimento de cobre na superfície da placa durante $\mathrm{o}$ reaquecimento antes da laminação. Conseqüentemente ocorre a difusão do cobre nos contornos de grão da austenita, possibilitando a ocorrência de trincas de liqüação. Neste caso, a adição de níquel é recomendada como medida corretiva. A tenacidade da ZAC pode ser incrementada pela adição de cobre $(0,12$ a $0,17 \%)$ em conjunto com o mesmo teor em níquel em situações que exijam soldas com elevada energia de soldagem [12]. 


\subsubsection{Efeitos deletérios de impurezas:}

O enxofre combina-se preferencialmente com o manganês para formar MnS. Este composto quando em excesso reduz a energia absorvida no ensaio de impacto Charpy. Altos valores de energia absorvida são benéficos nos aços para tubos, pois previnem a propagação de fratura dúctil. Nos aços API 5L atuais o teor de enxofre situa-se geralmente abaixo de 0,010\%. Entretanto, mesmo em teores baixos ainda existe o direcionamento da fratura devido a morfologia alongada do MnS. Deste modo, cálcio é adicionado a fim de que se combine com o enxofre formando partículas duras de sulfeto de cálcio que não se deformam durante a laminação [12]. A norma API 5L [9] recomenda que o teor de enxofre não exceda $0,015 \%$.

O fósforo está associado com a formação de uma linha central de segregação. Em aços produzidos por lingotamento contínuo, a concentração de fósforo na linha de segregação central é cerca de 10 a 20 vezes maior do que no restante do material. A presença de fósforo está relacionada com o aumento da atividade do carbono e a formação de microestruturas bandeadas de ferrita-perlita e ainda o endurecimento do composto MA (MartensitaAustenita) na ZAC após o ciclo térmico imposto pela soldagem. Estes efeitos

pioram a resistência à corrosão em meios contendo $\mathrm{H}_{2} \mathrm{~S}$ e $\mathrm{CO}_{2}$, restringindo a aplicação de aços com elevado teor de fósforo em aplicações sour-service. $\mathrm{O}$ teor de máximo recomendado de fósforo é de 0,020\% para aplicações envolvendo transporte de produtos com algum teor de umidade residual e de 0,015 a 0,010\% para aplicações sour-service. Pela norma API 5L [9] o teor de fósforo é limitado a $0,025 \%$.

O nitrogênio é absorvido da atmosfera durante as etapas de produção do aço, ou através da adição de ferro ligas contaminadas. A presença de nitrogênio está relacionada, entre outros, à redução da tenacidade da ZAC, quando este não está combinado com titânio e a formação de nitretos de nióbio $(\mathrm{NbN})$ durante a etapa de laminação, resultando em perda de eficiência da adição de nióbio, pois a tendência de formação de $\mathrm{NbN}$ é maior que a de formação de $\mathrm{NbC}$. Este efeito é pronunciado quando o aço permanece em temperaturas da ordem de 900 a $960^{\circ} \mathrm{C}$. O teor máximo recomendado de 
nitrogênio é de 0,008 a 0,009\%, em conjunto com teor de titânio entre 0,009 a 0,015\%, de forma a prevenir seus efeitos indesejados [12].

Outros elementos tais como: estanho, arsênico, antimônio e bismuto podem estar presentes devido à contaminação da sucata utilizada na fabricação do aço. Estes elementos reduzem a solubilidade do cobre na austenita e reduzem o ponto de fusão da camada enriquecida de cobre formada durante ciclos térmicos prolongados, intensificando a probabilidade de ocorrência de trincas a quente [12].

\subsubsection{Efeitos dos elementos modificadores de inclusões:}

Cálcio é adicionado ao aço com a finalidade de modificar o formato das inclusões de sulfeto de manganês (MnS). O cálcio é insolúvel no aço líquido, formando sulfetos, óxidos, oxisulfetos e aluminatos de cálcio, os quais são conduzidos para a escória através do borbulhamento de argônio. O teor de cálcio depende do teor de enxofre, sendo recomendado teor de 0,0010 a $0,0025 \%$. É prática comum especificar o teor de cálcio como duas vezes o teor de enxofre. Teor de cálcio maior que 0,0035 a 0,0040\% tende a reduzir a tenacidade e prejudicar a soldagem pelo processo MAG mecanizado. O cálcio atua como estabilizante de arco, reduzindo a largura do cordão, a freqüência de curto circuito e aumentando o tamanho da gota. A redução da freqüência de curto-circuito reduz a energia de soldagem, aumentando o índice de respingos e a incidência de falta de fusão [12].

Cério ou lantânio foram utilizados no começo dos anos 70 como agentes de controle da morfologia de inclusões de MnS. Esta técnica caiu em desuso em meados da década de 70 devido à tendência do excesso de cério residual $(0,04$ a $0,06 \%)$ utilizado no tratamento de aços com teor de enxofre alto $(0,015$ a $0,020 \%$ ) prejudicar a soldabilidade. Hoje em dia, em aços com teor de enxofre menor que $0,005 \%$, cério ou lantânio podem ser utilizados em substituição ao cálcio, limitando-se o teor residual em 0,020\%. O uso de cério caiu em desuso com a introdução da tecnologia de dessulfuração com cálcio no começo da década de 70. O lantânio pode ser utilizado para reduzir a segregação de fósforo [12]. 


\subsubsection{Propriedades mecânicas:}

A figura 11 mostra o limite de escoamento "LE" (em MPa e ksi) de alguns aços API 5L, segundo suas classes.

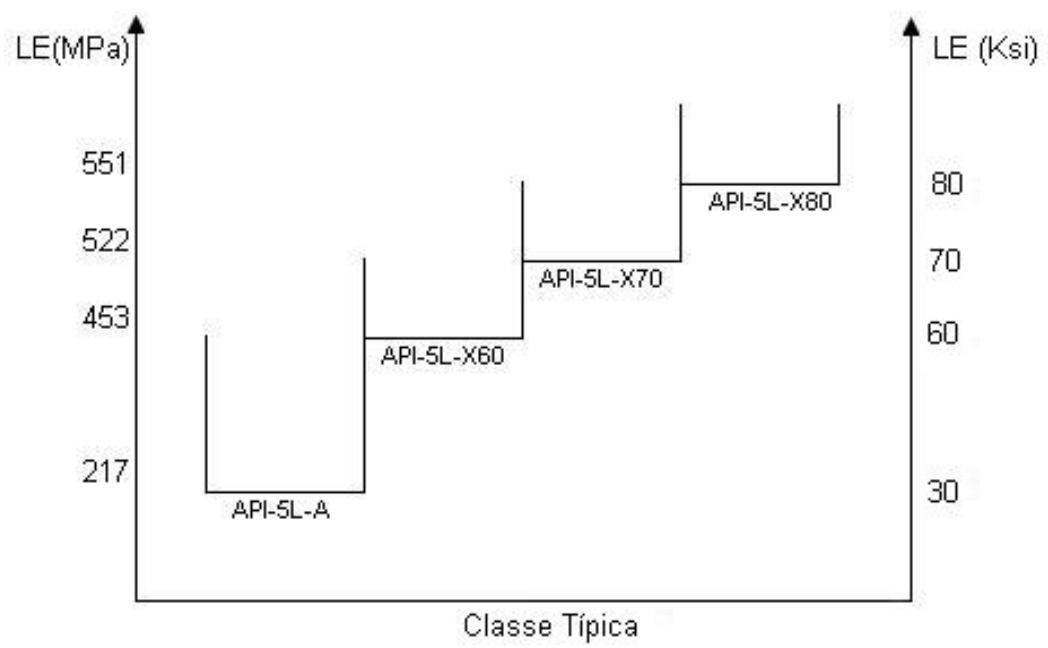

Figura 11 - Limite de escoamento em função das classes de aços API. Figura baseada na referência [38].

As propriedades mecânicas necessárias para 0 aço atingir a classificação X80, segundo a norma API 5L, devem ser conforme a tabela 10:

Tabela 10-Requisitos de propriedades mecânicas da API 5L X80 para o grau X80 [9].

\begin{tabular}{|c|c|c|c|}
\hline LE (mínimo) & LE (máximo) & LR (mínimo) & LR (máximo) \\
\hline $80 \mathrm{ksi}(552 \mathrm{MPa})$ & $100 \mathrm{ksi}(690 \mathrm{MPa})$ & $90 \mathrm{ksi}(621 \mathrm{MPa})$ & $120 \mathrm{ksi}(827 \mathrm{MPa})$ \\
\hline
\end{tabular}

O limite de escoamento segundo a norma API 5L [9] é a tensão de tração necessária para produzir um alongamento de $0,5 \%$ do comprimento útil do corpo de prova, medido com um extensômetro. Para um tubo expandido a frio a norma exige que a relação entre o limite de escoamento e o limite de resistência (LE/LR) não ultrapasse 0,93 [9]. A relação entre o limite de escoamento e o de resistência do aço estudado por Bott [27] é de 0,85.

O limite de escoamento e resistência do aço para tubo API $5 \mathrm{~L}$ X80 produzido no Brasil e estudado por Roza [18] é apresentado na tabela 11. 
Tábela 11- Propriedades mecânicas do aço estudado por Roza [18].

\begin{tabular}{|c|c|c|c|c|}
\hline & LE longitudinal & LE transversal & LR longitudinal & LR transversal \\
\hline API 5L X80 & $94 \mathrm{ksi}(648 \mathrm{MPa})$ & $88 \mathrm{ksi}(607 \mathrm{MPa})$ & $107 \mathrm{ksi}(738 \mathrm{MPa})$ & $111 \mathrm{ksi}(765 \mathrm{MPa})$ \\
\hline
\end{tabular}

O limite de escoamento no sentido longitudinal é maior que o do sentido transversal devido ao aumento de resistência mecânica obtido pela conformação mecânica. No sentido transversal a menor resistência mecânica é explicada pela ocorrência do efeito Bauschinger. Bott [27] cita que os aços bainíticos não possuem tendência de perder propriedades mecânicas após a etapa de conformação, ao contrário dos aços ferríticos-perlíticos.

Segundo a norma API 5L [9] o valor mínimo de energia absorvida no ensaio Charpy- $\mathrm{V}$ na temperatura de $0{ }^{\circ} \mathrm{C}$ tem de ser maior que $68 \mathrm{~J}$ no sentido transversal de laminação e $74 \mathrm{~J}$ no sentido longitudinal, apresentando $40 \%$ da área da fratura com comportamento dúctil [18].

No aço estudado por Roza [18], o valor médio de energia absorvida em três corpos de prova foi de $207 \mathrm{~J}$, com 100\% da área fraturada apresentando comportamento dúctil e temperatura de transição dúctil-frágil (50\% dúctil) abaixo de $-60^{\circ} \mathrm{C}$. A figura 12 apresenta a curva de transição dúctil-frágil do aço estudado por Roza [18], onde a linha tracejada representa $50 \%$ de fratura dúctil.

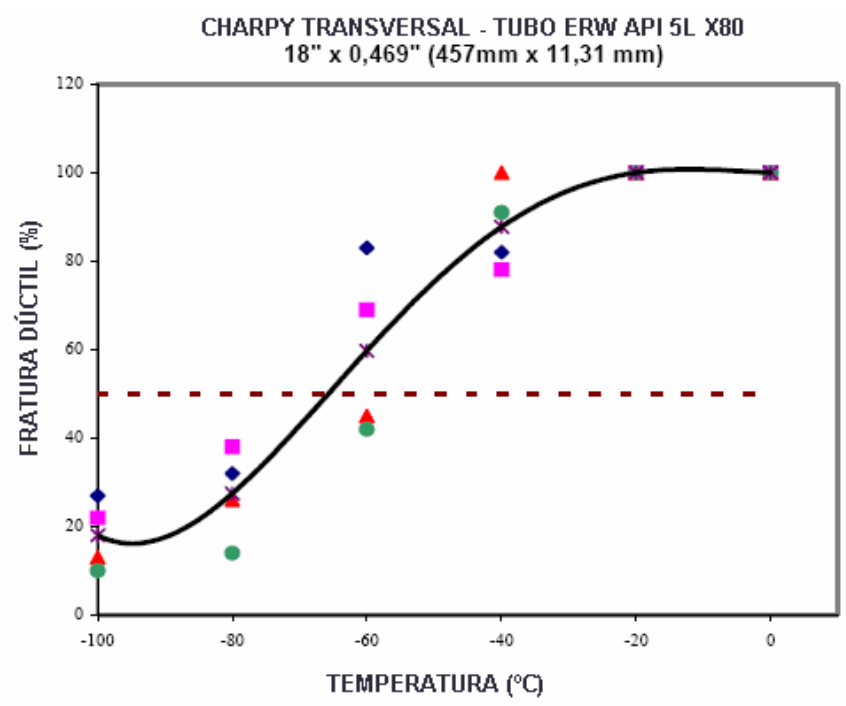

Figura 12 - Curva de transição dúctil-frágil do aço estudado por Roza [18] no sentido transversal. A linha tracejada representa $50 \%$ de fratura dúctil. Nota-se que a temperatura de transição ficou abaixo de $-60^{\circ} \mathrm{C}$. 
O perfil de dureza do aço estudado por Roza [18] apresentou comportamento homogêneo entre o metal de base, ZAC e metal de solda. O valor médio encontrado foi de $246 \mathrm{HV} 10$, sendo o de maior valor (253 HV10) encontrado no metal de base e o menor (235 HV10) na ZAC.

Bott [27] cita que as propriedades mecânicas do aço após a conformação podem sofrer alterações, devendo o produto acabado atender aos requisitos da norma API $5 \mathrm{~L}$.

\subsubsection{Processo de fabricação do tubo:}

Segundo a norma API 5L [9], os tubos podem ser fabricados com ou sem costura. O tubo sem costura é obtido pela conformação a quente do aço, através de laminação oblíqua ou extrusão, formando um produto tubular. Já os tubos com costura (soldados) são obtidos pela conformação a frio de chapas planas em formato cilíndrico, podendo ter disposição longitudinal ou helicoidal e utilizando ou não metal de adição.

\subsubsection{Tubos soldados com metal de adição - UOE:}

Neste processo de fabricação os tubos são obtidos a partir da conformação de chapas planas. Os tubos produzidos com este processo possuem normalmente as seguintes dimensões: comprimento de 6 a $13 \mathrm{~m}$, diâmetro externo de 13" a 48" e espessura de 6,4 a 31,8 mm [41].

O processo consiste na conformação da chapa em "U", após em "O" e expansão a frio "E". Em primeiro lugar as bordas da chapa são usinadas, formando o chanfro da junta soldada. Logo após a usinagem as bordas são prensadas em uma leve curva no sentido da curvatura do tubo, a fim de facilitar a etapa de fechamento em "O". A próxima etapa é a conformação da chapa em "U" e posteriormente o fechamento em "O". A figura 13 apresenta a conformação da chapa no formato "U". 


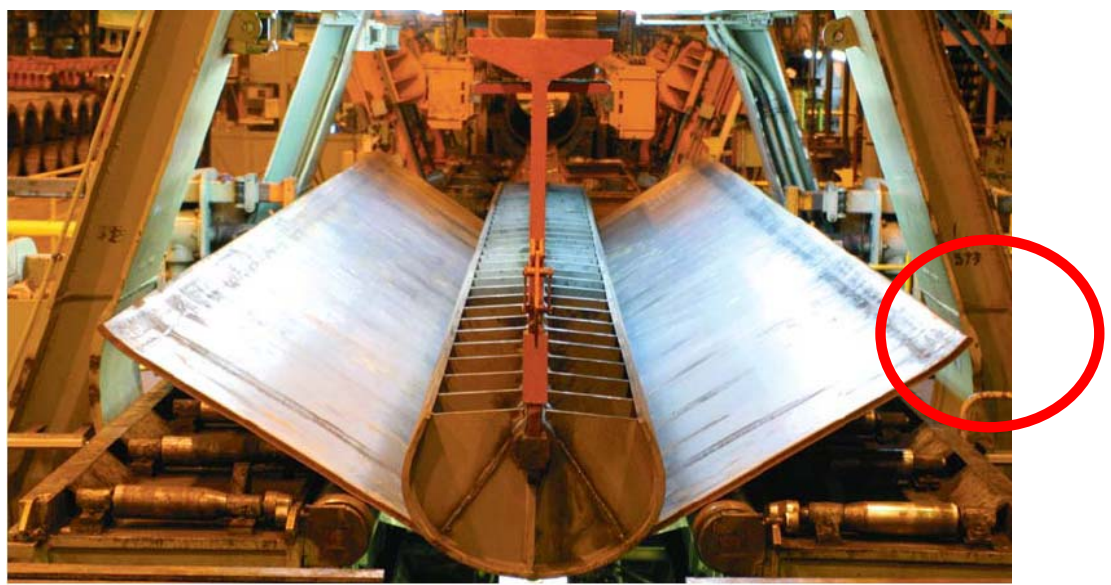

Figura 13 - Conformação da chapa no formato "U". Detalhe: Bordas prensadas no sentido da curvatura do tubo. Figura baseada na ref. [42].

Após estas duas etapas de conformação é executado o passe de selagem, inspeção visual, faceamento das extremidades e a soldagem das chapas apêndice. Em seguida são executados os passes de enchimento e acabamento interno e externo pelo processo SAS com técnica Tandem Arc com 4 arames [11]. A etapa seguinte consiste na inspeção da solda nas extremidades do tubo com ultra-som, expansão a frio e teste hidrostático. Após o teste hidrostático a solda do tubo é novamente inspecionada em $100 \%$ da extensão através do ensaio por ultra-som e radiográfico [41]. A figura 14 ilustra as etapas do processo de fabricação UOE.

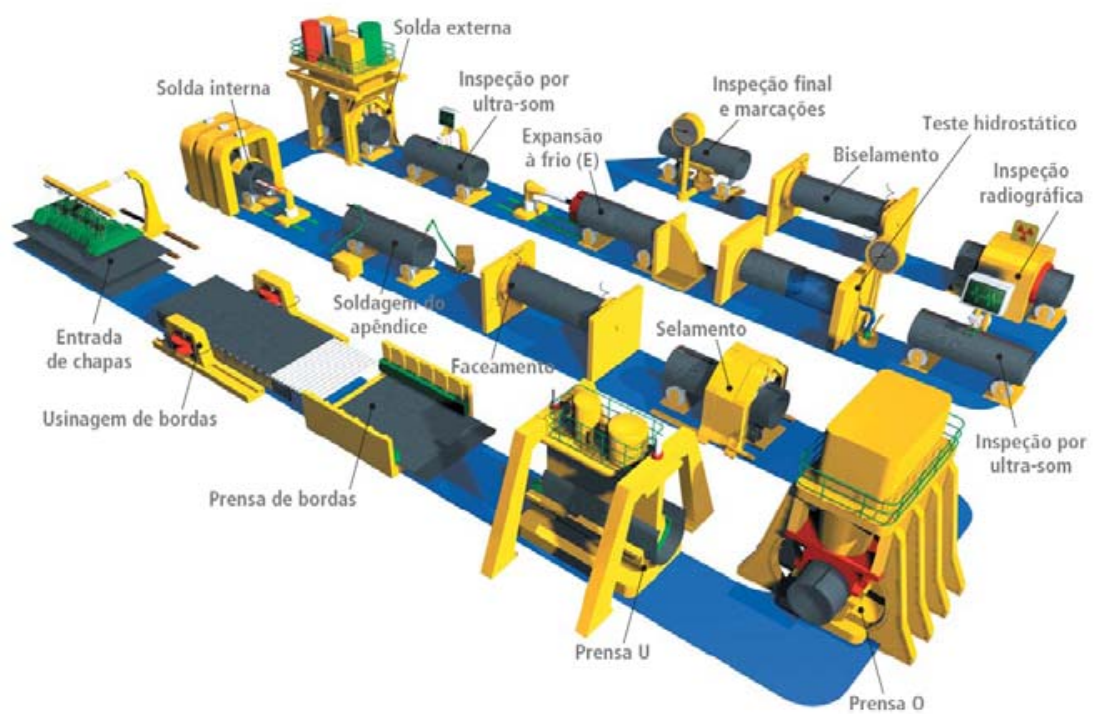

Figura 14- Etapas do processo de fabricação UOE [15]. 


\subsection{Processo de soldagem SAS:}

O processo de soldagem SAS utiliza um arco elétrico estabelecido entre o eletrodo e o metal base como fonte de calor para a fusão de ambos em conjunto com uma camada de fluxo granulado. O eletrodo é armazenado em uma bobina e é continuamente alimentado em direção à poça de fusão, onde é fundido e depositado juntamente com uma parcela também fundida do metal de base formando o metal de solda [43].

A proteção necessária para evitar a contaminação do metal de solda pelos gases da atmosfera (oxigênio e nitrogênio) é obtida pela fusão de um fluxo granulado, o qual se encontra previamente sobre a área a ser soldada. Este fluxo fundido mistura-se ao metal fundido auxiliando na purificação, desoxidação e adição de elementos de liga. Como possui menor densidade que o metal líquido, o fluxo fundido acaba por sobrenadar a poça de fusão, formando durante a solidificação uma camada vítrea (escória) que permanece aderida à parte superior do cordão de solda. Por apresentar alta fluidez e poça de fusão de grande tamanho, as duas únicas posições de soldagem possíveis são plana e horizontal [44].

A escória aderida ao cordão de solda proporciona a diminuição da taxa de resfriamento, permitindo deste modo que os gases dissolvidos no metal de solda escapem e evita ainda a contaminação com os gases da atmosfera. Esta proteção contra os gases da atmosfera é necessária, pois quando em alta temperatura o metal de solda reage em grande velocidade com os gases da atmosfera, ocasionando oxidação [1]. A porção de fluxo não fundida deve ser recolhida, peneirada e pode ser novamente aproveitada.

A progressão da soldagem é obtida por um deslocamento contínuo e com velocidade uniforme por toda a extensão da junta a ser soldada. A abertura de arco é obtida por curto circuito entre a ponta do eletrodo e o metal de base. É importante que a abertura e extinção de arco sejam efetuadas em uma chapa apêndice antes e depois da junta, a fim de que o arco esteja estabilizado antes de adentrar a junta. A figura 15 ilustra a poça de fusão obtida pelo processo de soldagem SAS [44]. 


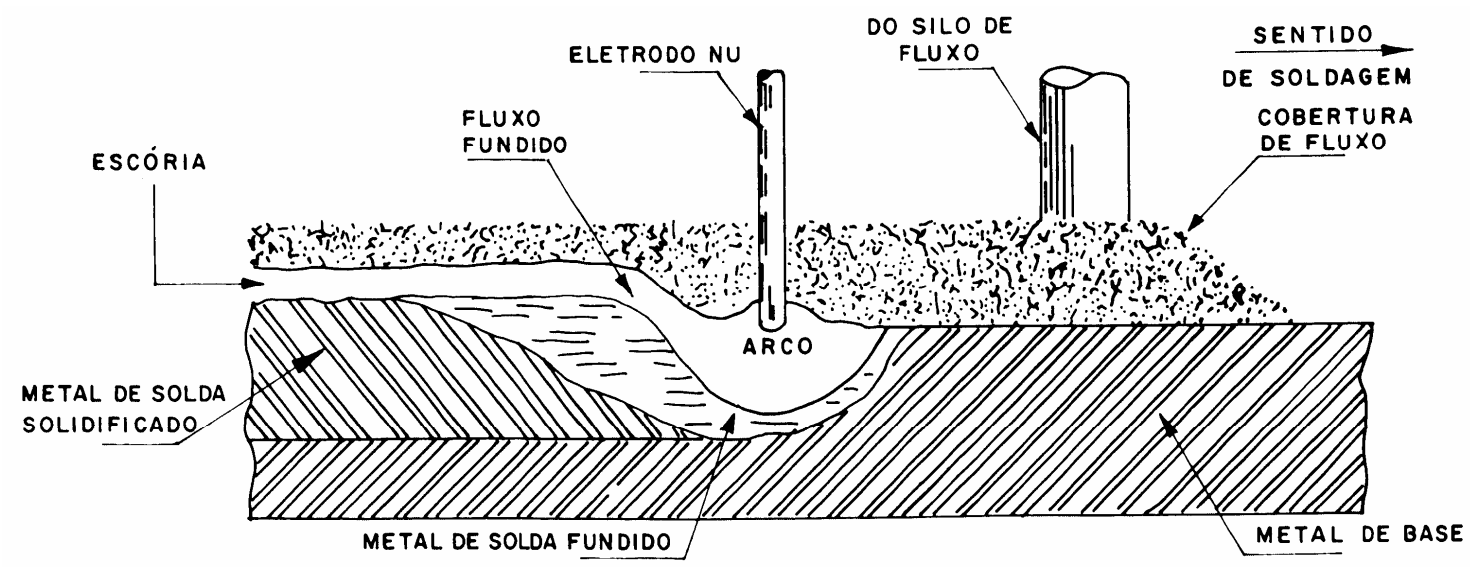

Figura 15 - llustração da poça de fusão do processo de soldagem SAS. Ref [1].

Este processo de soldagem é utilizado na soldagem de fabricação de tubos, pois proporciona alta taxa de deposição com alta qualidade de metal de solda e ainda, reúne as seguintes vantagens [45]:

- Alta velocidade de soldagem;

- Alta eficiência energética do processo;

- Uniformidade do cordão de solda;

- Ausência de respingos;

- Fácil automatização;

\subsection{Técnica Tandem-Arc:}

A técnica Tandem-Arc consiste no uso de dois ou mais eletrodos alimentados numa mesma poça de fusão, em posição paralela à junta, com alimentação e fontes de energia independentes. Neste caso, os arcos elétricos formados são independentes, com pequena distância entre si [46]. A figura 16 apresenta uma ilustração da técnica Tandem-Arc. 


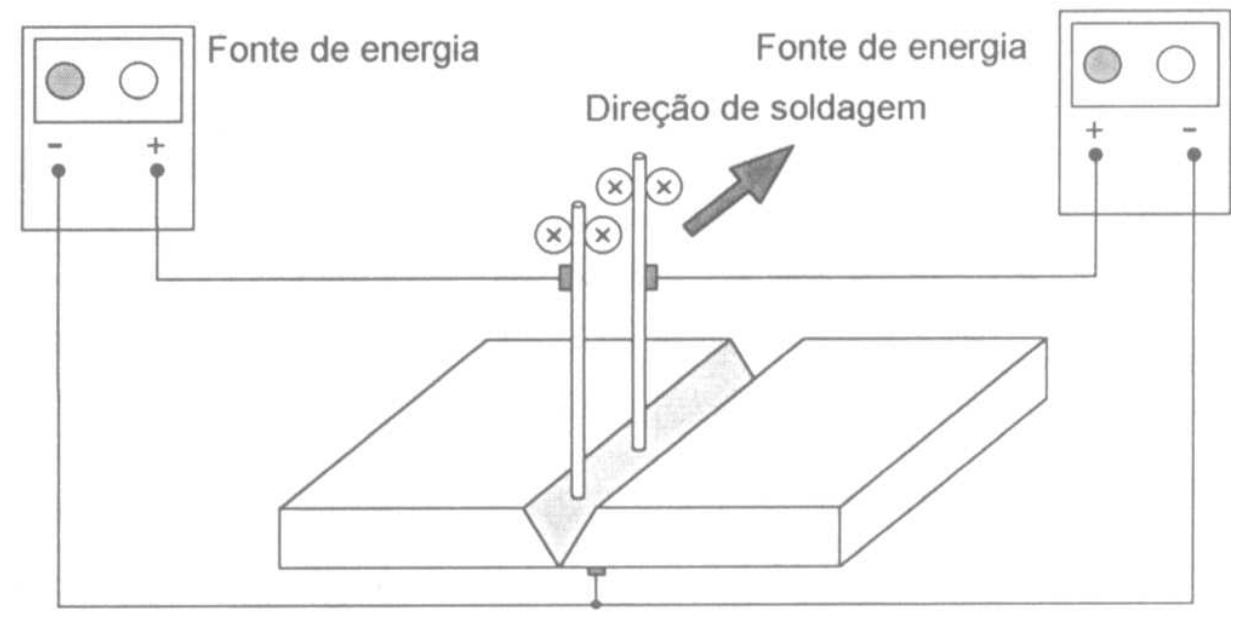

Figura 16- Técnica Tandem-Arc. Ref. [46].

O número máximo de eletrodos que podem ser empregados depende basicamente da necessidade real de aumento da taxa de deposição e do investimento necessário. A taxa de deposição obtida com esta técnica é expressivamente elevada, em relação à técnica com arame simples [46].

No caso de sistemas com 2 eletrodos, o primeiro é responsável pela penetração, e o segundo é responsável pelo enchimento e acabamento. No caso de um sistema com 3 ou mais eletrodos, a função do primeiro arame é equivalente a do sistema com 2 eletrodos, já o segundo e o terceiro são responsáveis pelo enchimento. $O$ último arame sempre é exclusivamente responsável pelo acabamento do cordão [46]. A figura 17 ilustra a função de cada eletrodo na deposição do metal de solda.

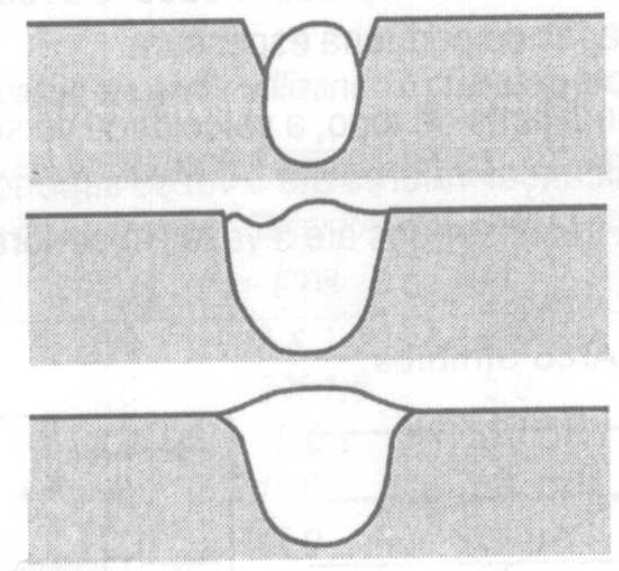

Figura 17- llustração da função dos eletrodos - Tandem-Arc. Ref [46]. 
A poça de fusão formada pelos eletrodos é contínua, ou seja, todos os arames estão sobre a mesma zona fundida, proporcionando deste modo uma solidificação uniforme [46].

A utilização desta técnica possibilita a diminuição da energia de soldagem em relação à espessura soldada, proporcionando assim melhor tenacidade em conjunto com alta taxa de deposição e velocidade [11].

A figura 18 apresenta a variação da energia absorvida no ensaio de impacto com a região da junta soldada, em relação a energia de soldagem utilizado e a figura 19 apresenta a relação entre a energia de soldagem e a espessura, utilizando-se a técnica Tandem-Arc com 4 eletrodos. Utilizando-se a técnica com 4 eletrodos, a energia de soldagem necessária em relação a espessura é menor do que se fosse utilizada a técnica de arame simples.

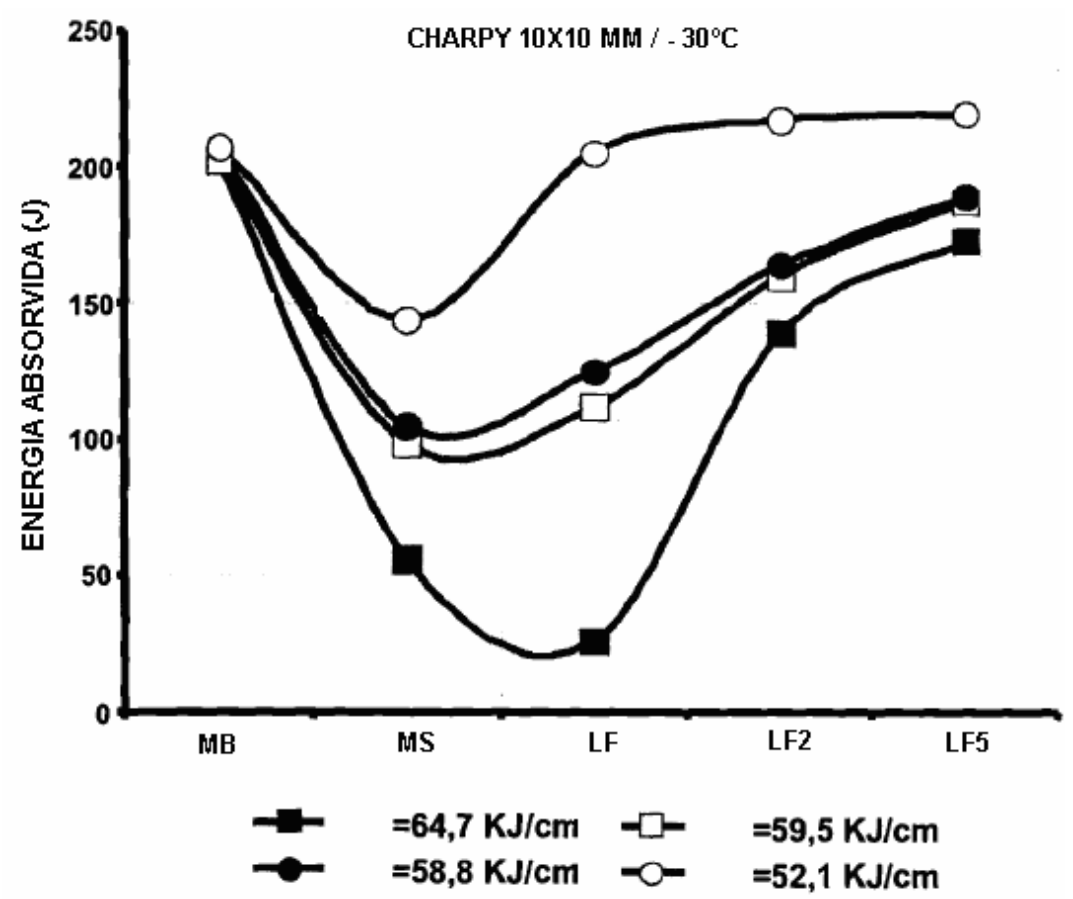

Figura 18- Variação da energia absorvida com a região da junta soldada, em relação a energia de soldagem utilizada Ref. [11]. 


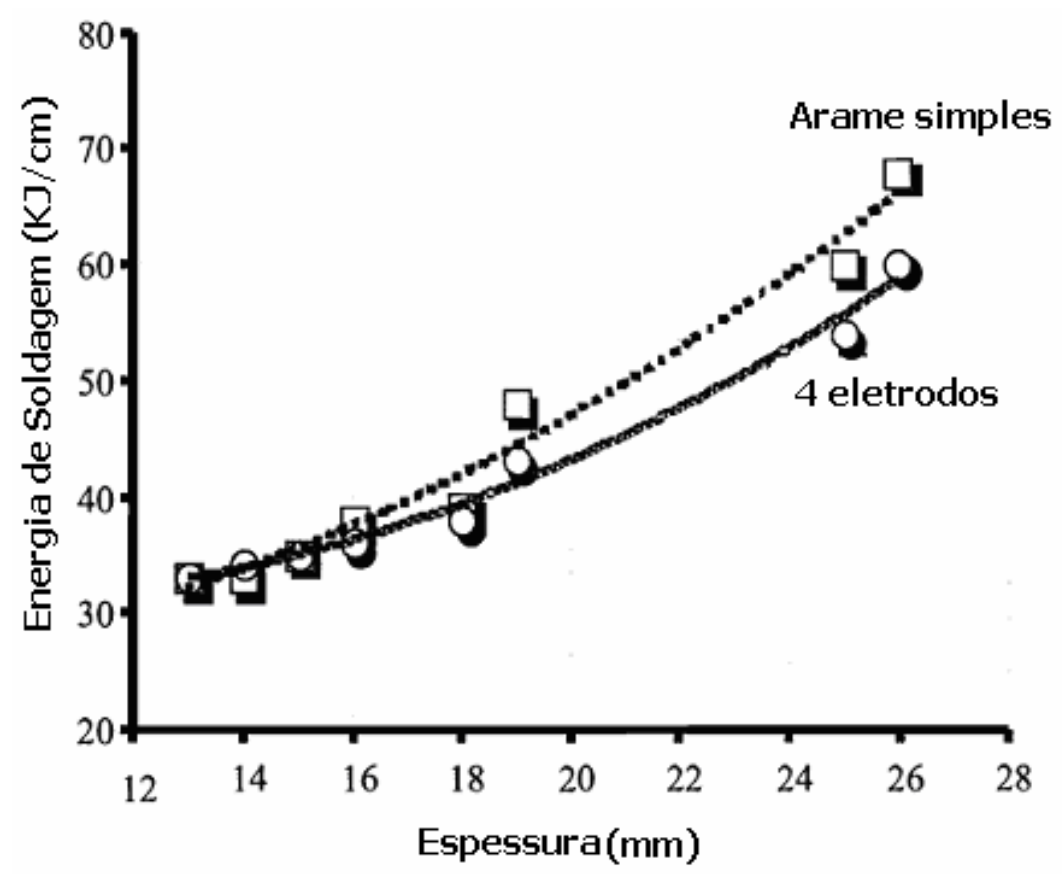

Figura 19- Relação entre a energia de soldagem e a espessura, utilizando-se a técnica Tandem-Arc com 4 eletrodos. Ref. [11].

\subsubsection{Soldabilidade:}

Segundo a AWS [47], a soldabilidade é definida como a capacidade de um material ser soldado sob as condições impostas de fabricação em uma estrutura específica e convenientemente projetada, de modo a executar satisfatoriamente o serviço pretendido. Este conceito pode ser subdividido em: soldabilidade operacional, soldabilidade metalúrgica e soldabilidade em serviço [48]. A soldabilidade operacional está relacionada as condições operacionais da soldagem como: combinação processo e natureza do metal de base; posição de soldagem; habilidade do soldador; técnicas de montagem das juntas, etc. A soldabilidade metalúrgica está associada a condições térmicas e químicas que podem gerar defeitos, ou propriedades mecânicas não desejadas, na junta soldada. A soldabilidade em serviço está mais relacionada a vidas útil do componente soldado. Neste item o foco será a soldabilidade metalúrgica.

Como foi descrito anteriormente, a soldabilidade dos aços, de um modo geral, é extremamente dependente da composição química e das condições térmicas, que determinam a microestrutura da junta soldada[49]. 
Durante a soldagem é formada, adjacente a zona fundida (ZF), uma região chamada de zona afetada pelo calor (ZAC). Esta região do metal base é submetida a um rápido ciclo térmico durante a etapa de soldagem, onde a temperatura atingida não é suficiente para ocasionar a fusão do metal base, mas o suficiente para que ocorram transformações de fase de ferrita para austenita no aquecimento e de austenita para diferentes microconstituintes no resfriamento[50]. A figura 20 apresenta uma representação esquemática das diferentes regiões de uma junta soldada.

Com o avanço da poça de fusão e/ou após o término da soldagem ocorre o resfriamento desta região. Dependendo da composição química do metal base, da temperatura máxima atingida no metal de base e da taxa de resfriamento pode ocorrer têmpera localizada, com aumento ou redução do tamanho de grão, formando microestruturas duras e frágeis na ZAC[50].

Um tipo de fragilização que estes aços podem sofrer é a fragilização por hidrogênio, gerando as trincas a frio induzidas por hidrogênio. Este tipo de fragilização é bastante sério e necessita de uma série de cuidados especiais, quando o aço é sensível a este tipo de fragilização.

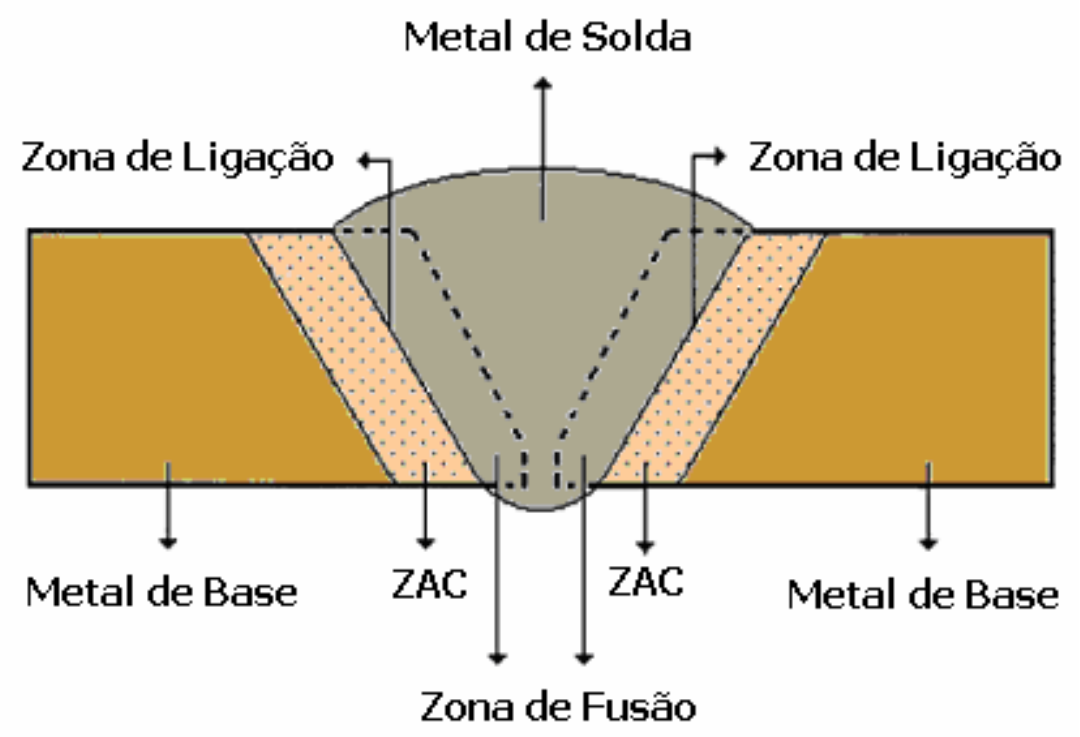

Figura 20- Representação das diversas regiões de uma junta soldada [51]. 


\subsubsection{Trincas por hidrogênio:}

A fragilização por hidrogênio pode ser classificada em dois mecanismos que atuam de maneira similar, porém estão associados ao teor de hidrogênio presente no material $[52,53]$. A fragilização pode estar associada à redução da energia de coesão do material e ou a presença de pressões de hidrogênio gasoso no interior do material, conhecido como empolamento (blister).

O hidrogênio é proveniente da umidade presente nos gases de proteção, sujeira e óxidos presentes no metal base e da umidade do revestimento dos eletrodos, sejam eletrodos revestidos ou tubulares. O uso de eletrodos celulósicos propicia a entrada de hidrogênio no metal de solda, pois seu revestimento é proveniente de matéria orgânica, rica em hidrogênio [14]. O controle do teor de hidrogênio residual é feito alterando-se o procedimento de soldagem (passe quente).

O hidrogênio quando está presente na atmosfera do arco, se dissocia em hidrogênio atômico, que é facilmente absorvido pela poça de fusão durante a soldagem. Após a solidificação da poça de fusão, ocorre uma diminuição da solubilidade do hidrogênio. Uma parte permanece dissolvida no estado sólido como hidrogênio atômico, e outra parte evolve para o meio ambiente na forma de gás hidrogênio. No estado sólido existe uma diferença de solubilidade do hidrogênio na ferrita e na austenita. A solubilidade do hidrogênio é maior na austenita que na ferrita. Assim, o hidrogênio difunde-se preferencialmente para regiões austenitizadas do metal base. Estas regiões podem sofrer têmpera devido a velocidade de resfriamento, associando assim o hidrogênio a um microconstituinte frágil, a martensita.

A difusão do hidrogênio é auxiliada por seu pequeno volume atômico, favorecendo o seu alojando-se próximo a defeitos, recombinando-se e formando gás hidrogênio, gerando um aumento da pressão interna, produzindo empolamento e trincas. Este mecanismo foi proposto por Granjon em 1972 $[54,55]$ e está esquematizado na figura 21. Nesta figura a temperabilidade do metal de solda é menor que do metal de base, concentrando o hidrogênio na ZAC. Caso as temperabilidades fossem invertidas, a concentração de hidrogênio seria no metal de solda. 


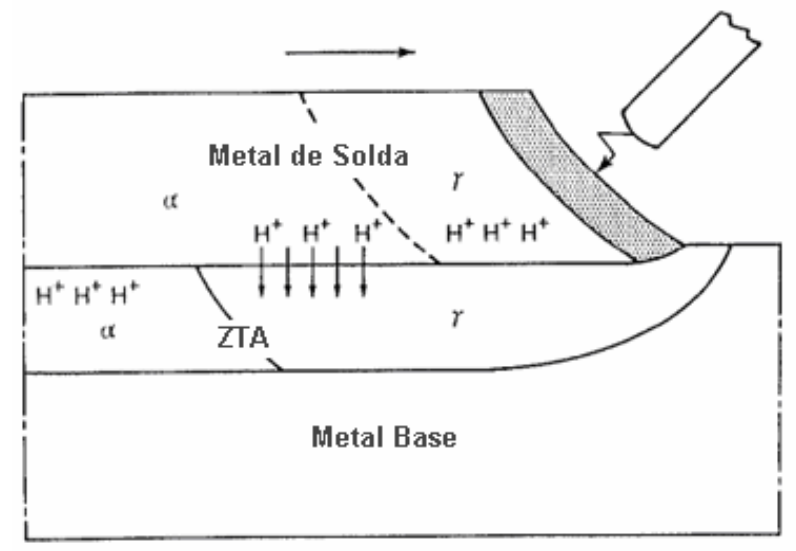

Figura 21- Representação esquemática da fragilização por hidrogênio, mostrando a absorção e a difusão do hidrogênio durante a soldagem, segundo Granjon [54].

A figura 22 apresenta um exemplo de trinca por hidrogênio, na qual a temperabilidade do metal de solda é menor que do metal de base. Neste caso as trincas originam-se preferencialmente na ZAC.

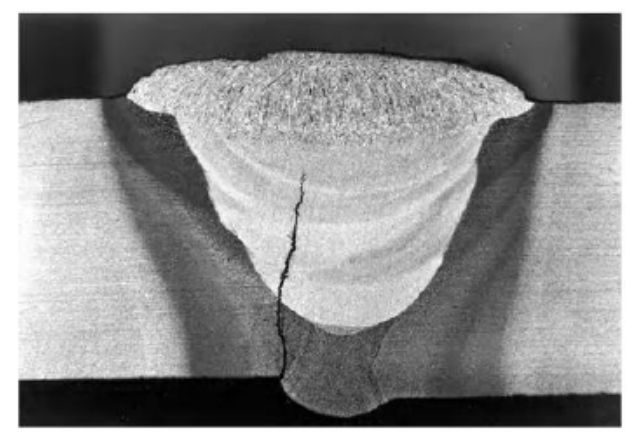

Figura 22- Trinca por hidrogênio na margem solda em um tubo de aço de alta resistência [22].

Para que possa ocorrer trinca por hidrogênio, é preciso que existam quatro fatores em conjunto [56]: fonte e quantidade de hidrogênio, microestrutura susceptível, tensões residuais de tração e temperatura entre 150 e $-60^{\circ} \mathrm{C}$.

O efeito da fragilização por hidrogênio é bastante crítico principalmente em aços de alta resistência e baixa ductilidade, quando um alto teor de hidrogênio é absorvido, pois estes não conseguem absorver as deformações plásticas produzidas, ocasionando desta forma a falha do material. Geralmente recomenda-se utilizar procedimentos com baixo hidrogênio para estes materiais. 
As tensões residuais de tração estão presentes na junta soldada, devido ao aquecimento e resfriamento não uniforme. Elas podem ser reduzidas quando se realiza um tratamento térmico pós-soldagem de alívio de tensões.

O mecanismo de fragilização por hidrogênio atua na faixa de temperatura de 150 e $-60^{\circ} \mathrm{C}$. Isto significa que, durante a soldagem, cuidados especiais devem ser tomados para evitar que a junta soldada atinja esta faixa de temperatura. Os outros efeitos serão discutidos a seguir.

3.3.6.2 Influência da composição química no comportamento da ZAC durante o resfriamento:

A influência da composição química é determinada por uma fórmula que leva em consideração a influência de cada elemento de liga na temperabilidade do aço em relação ao carbono. O carbono foi escolhido como ponto de referência, por ser um dos elementos mais eficazes e comuns como agente de aumento de resistência mecânica dos aços. O fator obtido através desta fórmula é conhecido como carbono equivalente, servindo como base para determinar a soldabilidade do metal de base [12]. A fórmula leva em conta o efeito dos diferentes elementos de liga na transformação martensítica dos aços carbono, baixa, média e alta liga.

Atualmente existem duas fórmulas mais comumente utilizadas para o cálculo do carbono equivalente, ambas apresentadas abaixo [12]:

$$
\begin{gathered}
C E_{I I W}=C+\frac{M n}{6}+\frac{(C r+M o+V)}{5}+\frac{(N i+C u)}{15} \\
P_{c m}=C+\frac{S i}{30}+\frac{M n}{20}+\frac{C u}{20}+\frac{N i}{60}+\frac{C r}{20}+\frac{M o}{15}+\frac{V}{10}+5 B
\end{gathered}
$$


A primeira fórmula (equação 01) é conhecida como formula do carbono equivalente do IIW (International Institute of Welding). Foi desenvolvida na década de 40 para aços normalizados de com alto teor de carbono, entretanto pela vasta aplicação ainda é especificada pela API $5 \mathrm{~L}$. Valores abaixo de 0,45 indicam boa soldabilidade metalúrgica dos aços, enquanto valores acima deste requerem alguns cuidados quando da soldagem. Aços API $5 \mathrm{~L}$ modernos possuem o valor do carbono equivalente calculado com esta fórmula em torno de 0,35 ou menos. Alguns aços X80 possuem valor entre 0,40 a 0,45 [12].

A segunda fórmula (equação 02) é conhecida como parâmetro do carbono equivalente ou fórmula de Ito-Bessyo. Foi desenvolvida na década de 60 no Japão especificamente para os novos aços com teor de carbono mais baixo. Valores entre 0,18 a 0,20 são compatíveis com o valor 0,40 da fórmula anterior [12].

A norma API 5L especifica que para os aços com teor de carbono menor que $0,12 \%$ deve ser utilizada a fórmula $P_{c m}$, e acima de $0,12 \%$, a fórmula $\mathrm{CE}_{\| I w}$ [9].

\subsubsection{Influência da taxa de resfriamento:}

Quanto maior for a taxa de resfriamento, maior será a resistência mecânica. A taxa de resfriamento depende de vários fatores, tais como: propriedades físicas do material, pré-aquecimento, temperatura interpasse, espessura do tubo, energia de soldagem e geometria da junta [5].

O pré-aquecimento é empregado com o objetivo de diminuir a taxa de resfriamento. A temperatura de pré-aquecimento pode ser determinada em função do cálculo do carbono equivalente. A figura 23 mostra um gráfico da temperatura de pré-aquecimento em função do carbono equivalente. A linha tracejada delimita os aços API até X100. Na soldagem do aço X80 os valores de pré-aquecimento utilizados situam-se entre 100 a $150^{\circ} \mathrm{C}$. Hilldenbrand [16] relacionou o risco de trincamento em função da temperatura de préaquecimento e do carbono equivalente, utilizando-se de eletrodos celulósicos. 


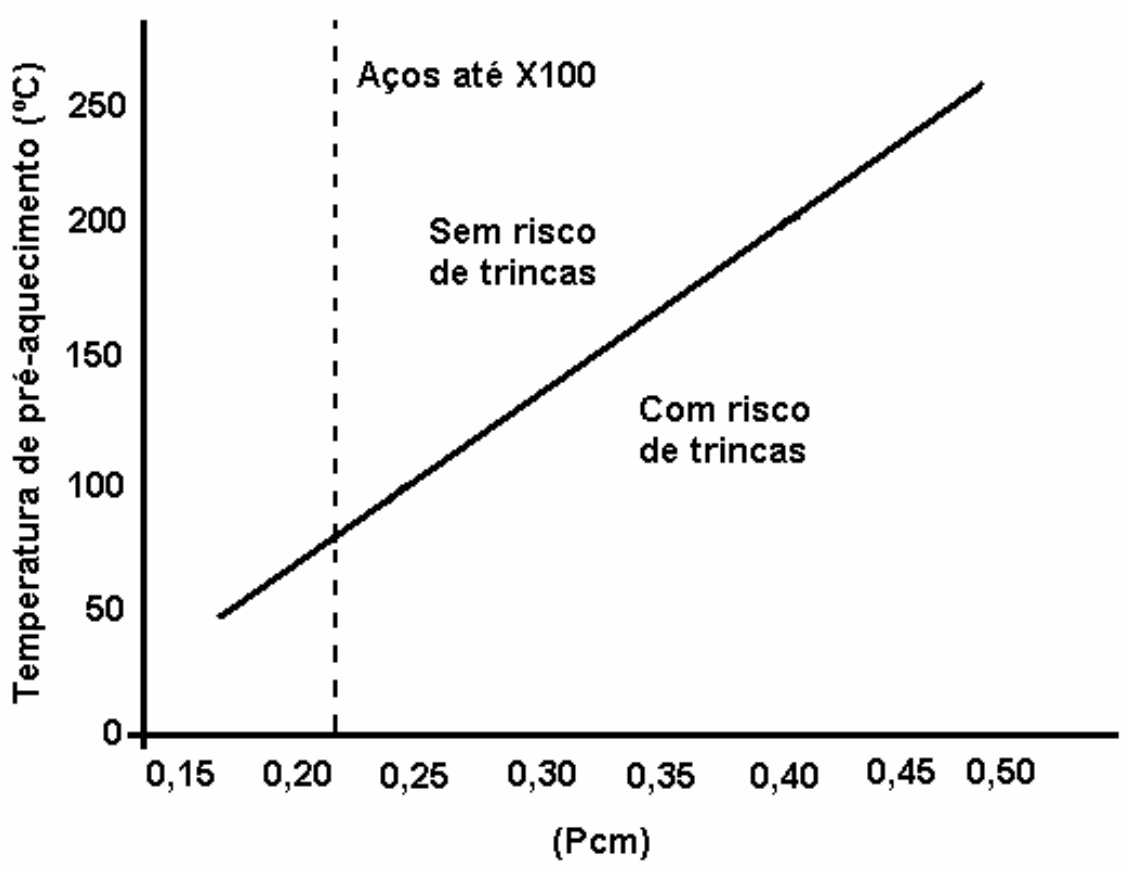

Figura 23- Relação entre a temperatura de pré-aquecimento em função do carbono equivalente [16].

Em tubos com a parede mais espessa, a extração de calor para o restante do metal base é maior, aumentando a taxa de resfriamento. Portanto, quanto maior for a espessura do tubo, maior será a taxa de resfriamento e conseqüentemente o endurecimento obtido na ZAC. Os tubos com parede mais espessa também estão sujeitos a maior contração durante a etapa de soldagem, resultando em maiores tensões residuais [5].

O diâmetro do tubo também afeta a soldabilidade, pois tubos com grandes diâmetros tendem a aumentar o tempo entre passes, resultando no resfriamento mais rápido do cordão de solda, podendo gerar trincas [22].

A energia de soldagem é definida como a quantidade de calor empregado na soldagem por unidade de comprimento. Quanto maior for a energia de soldagem, menor será a taxa de resfriamento. A energia de soldagem é calculada pela seguinte equação[57]:

$$
E=\frac{\eta \cdot V . I}{v_{s}}
$$

Onde: $V$ = tensão do arco; $I$ = corrente de soldagem; $\eta$ = eficiência de transferência de calor do processo de soldagem e $v_{s}=$ Velocidade de Soldagem. 
A eficiência de transferência de calor é diferente para cada processo de soldagem, e está relacionado à quantidade de energia fornecida pelo arco e a quantidade realmente empregada na soldagem. A tabela 12 apresenta os rendimentos de cada processo de soldagem.

Tabela 12- Eficiência de transferência de calor dos processos de soldagem. Ref. [57].

\begin{tabular}{|c|c|}
\hline Processo & Eficiência $(\eta)$ \\
\hline SAS & 0,99 \\
\hline ER & 0,9 \\
\hline MAG & 0,7 a 0,8 \\
\hline TIG & 0,3 a 0,5 \\
\hline
\end{tabular}

Uma maneira para determinar se a junta soldada terá alguma região temperada é através do cálculo do tempo de resfriamento entre as temperaturas de 800 e $500^{\circ} \mathrm{C}\left(\Delta \mathrm{t}_{8-5}\right)$.

No caso de chapa grossa e no centro do cordão de solda, a equação para calcular o $\Delta \mathrm{t}_{8-5}$ é dada por [58]:

$$
\Delta t_{8-5}=\frac{\eta \cdot V . I}{2 \pi \lambda v_{s}}\left(\frac{1}{773-T_{0}}-\frac{1}{1073-T_{0}}\right)
$$

onde:

$\lambda=$ condutividade térmica $\left(41 \mathrm{Jm}^{-1} \mathrm{~s}^{-1} \mathrm{~K}^{-1}\right)$

$\mathrm{T}_{\mathrm{o}}=$ temperatura inicial da chapa $(\mathrm{K})$

De uma maneira geral $\circ \Delta t_{8-5}$ é maior que $10 \mathrm{~s}$ para aços com temperabilidade elevada [59-61]. Este valor de $\Delta t_{8-5}$ impediria que a ZAC fosse temperada, resultando em uma microestrutura martensítica. Esta microestrutura associada ao teor de hidrogênio e tensões residuais de tração pode gerar trincas. 
Para avaliar a resistência à fragilização por hidrogênio ou as transformações de fase em função da velocidade de resfriamento é importante conhecer a curva de resfriamento continuo do aço (Curva CRC). Existem diversas curvas de resfriamento contínuo de aços API $5 \mathrm{~L}$ X80 publicadas [26, 62-64]. A figura 24 apresenta algumas curvas CRC publicadas na literatura.

A composição química dos aços estudados para a construção das curvas de resfriamento contínuo eram: para ref. 62 : $\mathrm{C}=0,08 \% ; \mathrm{Mn}=1,70 \% ; \mathrm{Si}$ $=0,25 \% ; P=0,021 \% ; S=0,002 \% ; A l=0,029 \% ; \mathrm{Nb}=0,033 \% ; \mathrm{V}=0,058 \% ; \mathrm{Ni}$ $=0,17 \% ; \mathrm{B}=0,0024 \% ; \mathrm{Ti}=0,026 \% ; \mathrm{N}=40$ ppm; para ref. $63: \mathrm{C}=0,05 \% ; \mathrm{Mn}=$ $1,55 \% ; \mathrm{P}=0,018 \% ; \mathrm{S}=0,005 \% ; \mathrm{Cu}+\mathrm{Ni}+\mathrm{Cr} \leq 0,60 \% ; \mathrm{Nb}=0,095 \% ; \mathrm{Ti} \leq$ $0,025 \% ; \mathrm{N}=80$ ppm, para a ref. 64 com manganês elevado: $\mathrm{C}=0,08 \% ; \mathrm{Mn}=$ $1,55 \% ; \mathrm{Si}=0,41 \% ; \mathrm{Al}=0,027 \% ; \mathrm{Mo}=0,18 ; \mathrm{Nb}=0,031 \% ; \mathrm{Ti}=0,013 \% ; \mathrm{N}=44$ ppm e finalmente para a ref. 64 com manganês baixo: $\mathrm{C}=0,07 \%$; $\mathrm{Mn}=1,08 \%$; $\mathrm{Si}=0,09 \% ; \mathrm{Al}=0,032 \% ; \mathrm{Mo}=0,19 ; \mathrm{Nb}=0,040 \% ; \mathrm{Ti}=0,014 \% ; \mathrm{N}=29 \mathrm{ppm}$. 
(a)

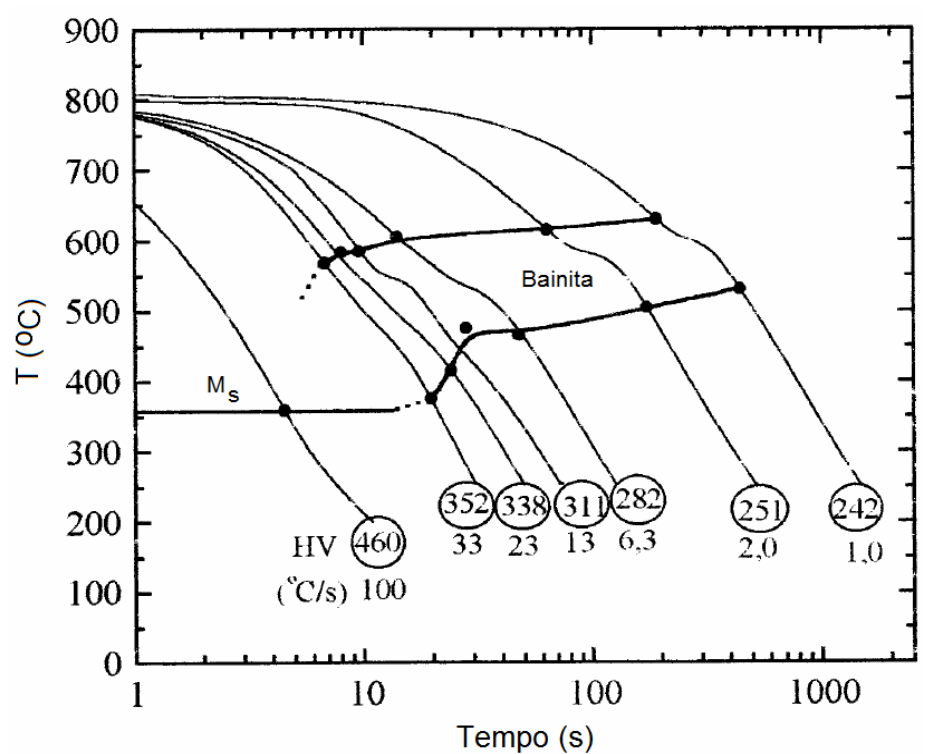

(c)

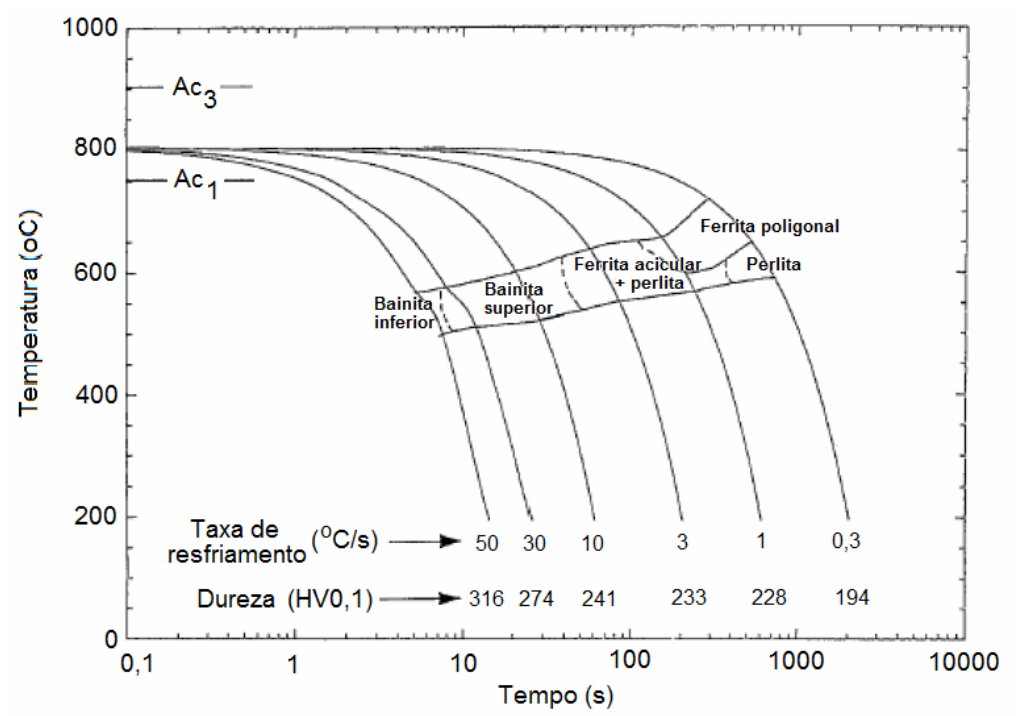

(b)

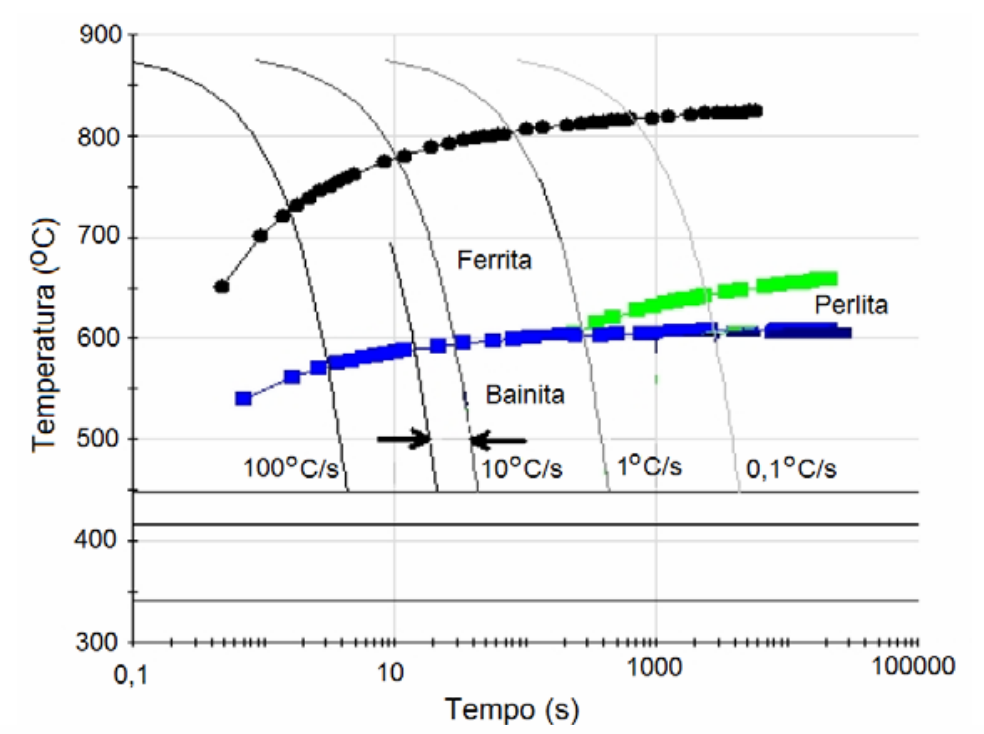

(d)

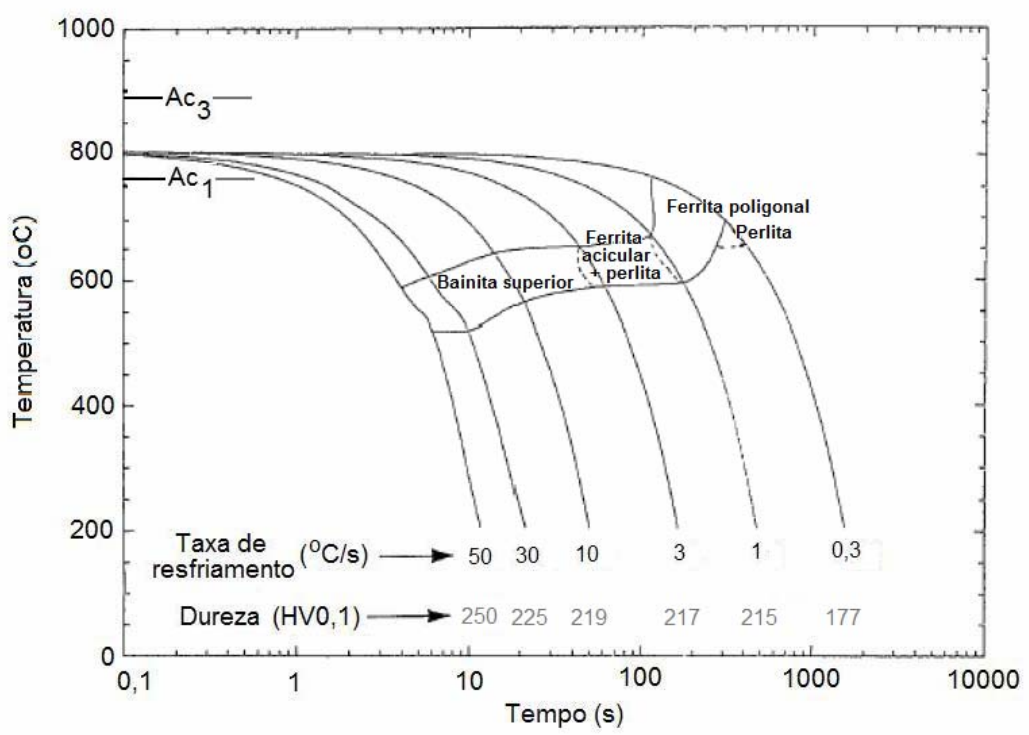

Figura 24- Curvas de resfriamento contínuo (CRC) para o aço API X80. (a) ref. 62; (b) ref. 63; (c) ref. 64 baixo Mn e Si e (d) ref. 64 alto Mn e Si. 


\subsubsection{Soldabilidade tubo API 5 L X80 nacional:}

Segundo Bott [27], o correto equilíbrio entre resistência mecânica e tenacidade dos aços API pode ser prejudicado na ZAC, devido a ciclos térmicos empregados na etapa de soldagem.

Este equilíbrio é extremamente dependente da composição química [21]. No caso do aço nacional é utilizado um alto teor de elementos de liga para obter a resistência mecânica necessária, a fim de compensar a ausência de resfriamento acelerado [27].

Este alto teor de elementos de liga aumenta o CE para valores entre 0,20 a 0,30, prejudicando a soldabilidade. A tabela 13 apresenta o CE dos aços nacionais estudados por diversos autores.

Tabela 13- Carbono Equivalente dos aços API 5L X80 nacionais estudados por diversos autores.

\begin{tabular}{|c|c|c|c|c|c|c|c|c|c|c|c|c|}
\hline $\mathrm{CE}$ & 1 & 2 & 3 & 4 & 5 & 6 & 7 & 8 & 9 & 10 & 11 & 12 \\
\hline $\mathrm{P}_{\mathrm{cm}}$ & 0,16 & 0,18 & 0,18 & 0,1597 & 0,156 & 0,17 & 0,125 & 0,1809 & 0,1944 & 0,197 & 0,20 & 0,19 \\
\hline $\mathrm{CE}_{\| \mathrm{II}}$ & - & - & - & 0,43 & - & 0,42 & - & 0,43 & - & - & - & - \\
\hline
\end{tabular}

1 X80 liga NbCr utilizado por Bott e Valim ref. [27,17].

2 X80 liga NbCrMo utilizado por Bott e Valim ref. [27,17].

3 X80 utilizado por Roza ref. [18].

4 X80 utilizado por Ferreira ref. [11].

5 X80 utilizado por Silva e Ordoñez ref. [32,4].

6 X80 utilizado por Zacca ref. [33].

7 X80 utilizado por Ramirez ref. [26].

$8 \times 80$ utilizado por Caloi ref. [34].

9 X80 utilizado por Pinto ref. [35].

$10 \times 80$ utilizado por Durant ref. $[36,37]$.

11 Primeiro X80 fabricado no Brasil - Liga NbVCrNi ref. [31].

12 Primeiro X80 fabricado no Brasil - Liga NbMoTi ref. [31].

No aço estudado por Bott [27], a tenacidade da ZAC foi ligeiramente maior que a do metal base, sendo que o normal seria o contrário. A perda ou ganho de tenacidade na ZAC está relacionada com a presença de MA (Martensita-Austenita), não somente em relação à fração volumétrica, mas também com a morfologia, tamanho e distribuição. A fração volumétrica do MA (Martensita-Austenita) é diretamente proporcional ao teor de carbono e dos 
elementos formadores de carbonetos, pois estes retardam a decomposição do MA (Martensita-Austenita) [21].

A tabela 14 apresenta a fração volumétrica de MA (Martensita-Austenita) no aço estudado por Bott [27].

Tabela 14- Fração volumétrica de MA (Martensita-Austenita) no aço estudado por Bott [27].

\begin{tabular}{|c|c|c|c|c|c|c|}
\hline \multirow{2}{*}{} & & \multicolumn{2}{|c|}{$\begin{array}{c}\text { Fração volumétrica de MA (Martensita- } \\
\text { Austenita) }\end{array}$} & \multicolumn{2}{c|}{ Energia Absorvida (J) Aprox. } \\
\hline Liga & CE & Metal Base & ZAC & $\begin{array}{c}\text { Metal } \\
\text { Base }\end{array}$ & ZAC & $\begin{array}{c}\text { Metal de } \\
\text { Solda }\end{array}$ \\
\hline $\mathrm{NbCrMo}$ & 0,18 & $5,1 \%$ & $8,3 \%$ & 100 & 125 & 75 \\
\hline $\mathrm{NbCrMo}$ & 0,15 & $5,2 \%$ & $7,3 \%$ & 150 & 225 & 150 \\
\hline $\mathrm{NbCr}$ & 0,16 & $3,4 \%$ & $5,3 \%$ & 115 & 150 & 75 \\
\hline $\mathrm{NbCr}$ & 0,16 & $2,6 \%$ & $7,2 \%$ & 215 & 250 & 100 \\
\hline
\end{tabular}

Embora a fração volumétrica de MA (Martensita-Austenita) na ZAC seja maior que no metal base, a ZAC obteve maior tenacidade. Bott [27] explica que esta diferença foi devido a diferenças no tamanho e na distribuição do MA (Martensita-Austenita) entre o metal base e a ZAC. No aço $\mathrm{NbCr}$ e NbCrMo a morfologia é idêntica, mas o tamanho das partículas é menor e o espaço entre elas maior, não estando interconectadas.

A figura 25 apresenta a micrografia da ZAC e do metal de solda dos aços estudados por Bott [27]. A micrografia do metal base é apresentada na Figura 6.

Em relação as propriedades mecânicas de tração e dureza da ZAC, Bott [27] afirma que o ciclo térmico de soldagem aumenta a dureza e diminui o limite de escoamento da ZAC. Nos aços estudados não houve variações significativas na dureza encontrada na ZAC e na resistência a tração do metal de solda. A dureza obtida na ZAC foi menor $(\sim 225 \mathrm{Hv})$ que a do metal de solda e do metal base ( $245 \mathrm{HV})$. Nos ensaios de tração todas as rupturas ocorreram no metal base, devendo o metal de solda apresentar limite de resistência maior que o metal base.

No aço estudado por Roza [18] a dureza média encontrada na ZAC é de $240 \mathrm{HV}$; no metal base e metal de solda a dureza média encontrada foi de 250 HV. 


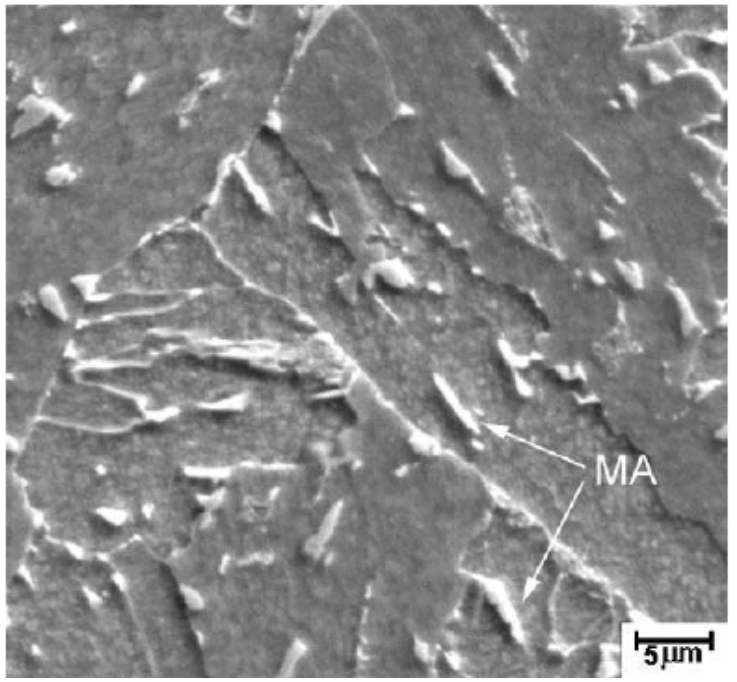

(a)

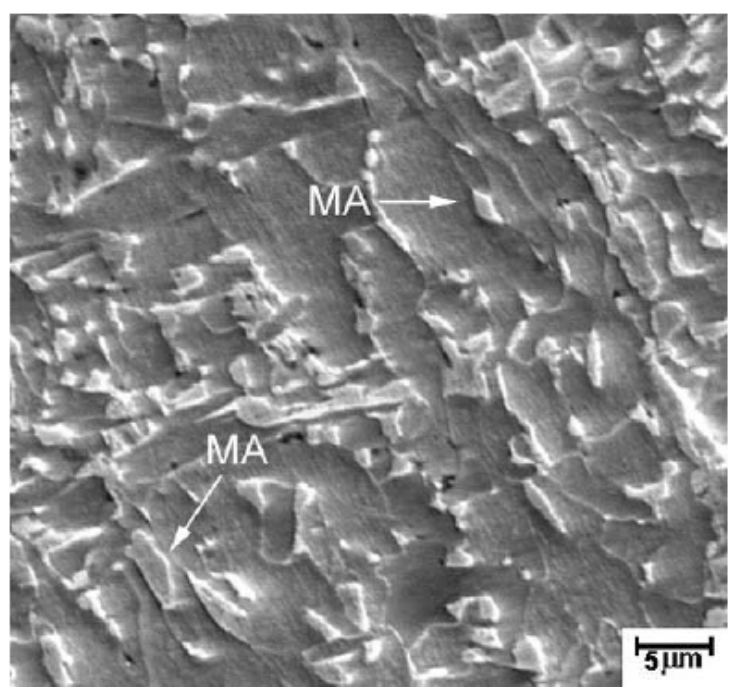

(c)

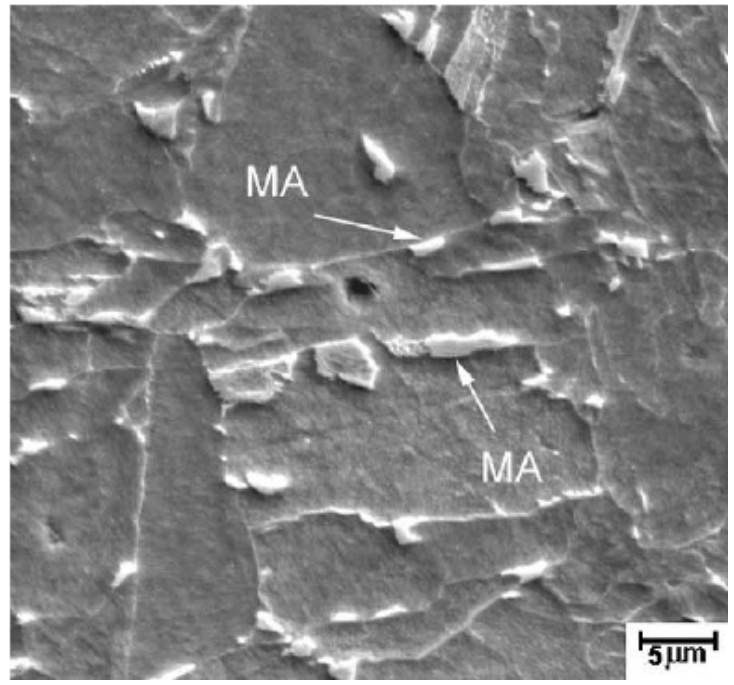

(b)

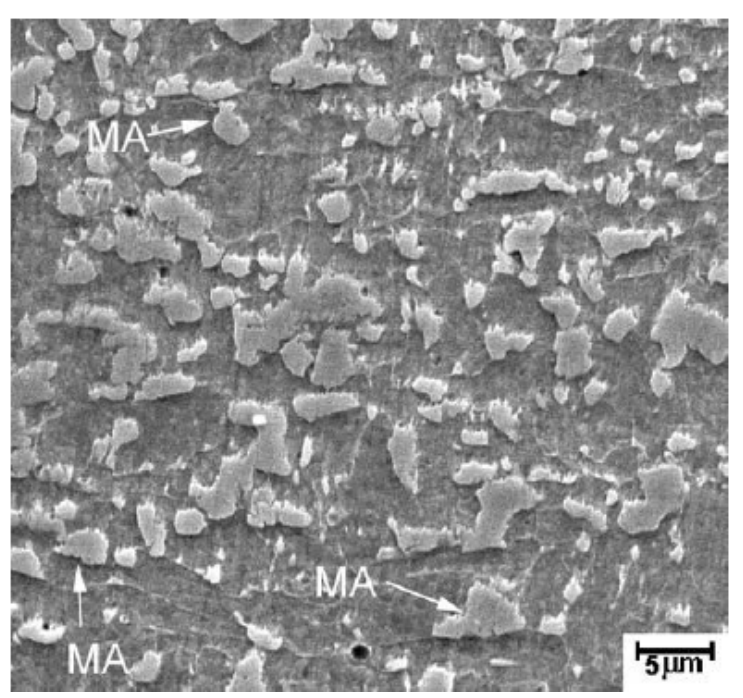

(d)

Figura 25- Micrografia ZAC e do metal de solda dos aços estudados por Bott [27]. (a) e (c) liga $\mathrm{NbCrMo;} \mathrm{(b)} \mathrm{e} \mathrm{(d)} \mathrm{liga} \mathrm{NbCr}$.

\subsection{Soldagem em campo:}

Os processos de soldagem mais comumente utilizados na soldagem de dutos em campo são: ER, MAG, AT, SAS e TIG. Entretanto, os dois últimos apresentam limitações quanto à posição de soldagem e produtividade, respectivamente [65]. 
Independentemente do processo de soldagem utilizado e, especialmente na soldagem de tubos acima do grau X70, a fim de prevenir a ocorrência de defeitos de soldagem, Bai [5] recomenda que seja dada especial atenção a:

- Preparação da junta e alinhamento;

- Pré-aquecimento adequado;

- Limpeza entre passes;

- Parâmetros de soldagem;

- Não movimentar o tubo antes de completar o passe de raiz.

O processo de soldagem ER é o mais utilizado na soldagem de dutos em campo [5]. Atualmente, mesmo com o desenvolvimento de novos materiais e processos de soldagem, o processo ER continua sendo empregado devido principalmente à: facilidade de uso; possibilidade de soldagem em condições de difícil acesso; possibilidade de uso de fontes de soldagem motogeradoras; não necessita de gás de proteção [66].

Os processos que apresentam maior possibilidade de substituição ao ER são o MAG e AT. O emprego destes processos de soldagem permite aumentar a produtividade e reduzir o custo de soldagem, mas em contrapartida exigem equipamentos mais sofisticados e podem necessitar de gás de proteção [67]. O processo MAG é mais sensível a variações no valor do carbono equivalente e principalmente ao teor de boro do metal base. $O$ processo AT é utilizado mais freqüentemente na soldagem de reparos em dutos. As propriedades do AT são boas, embora historicamente haja restrições quanto à tenacidade [5].

O processo SAS possui restrições quanto à posição de soldagem. Quando utilizado, as propriedades mecânicas do metal de solda sofrem grande influência dos elementos de liga do metal base. O alumínio pode especialmente prejudicar a tenacidade do metal de solda. O processo TIG produz soldas com excelente qualidade e propriedades, mas não apresenta boa produtividade [5]. 


\subsubsection{Processo MAG-TC:}

O processo de soldagem MAG-TC é uma derivação do processo MAG para a soldagem de passe de raiz em tubulações, desenvolvida e patenteada pela The Lincoln Electric Company com o nome comercial "STT ${ }^{\circledR}$ (Surface Tension Transfer)". O processo de soldagem MAG consiste em um arco elétrico estabelecido entre a ponta de um eletrodo contínuo sólido fornecido na forma de bobinas e o metal de base. A proteção da poça de fusão é realizada com o emprego de um gás de proteção armazenado em cilindros. Este gás de proteção pode ser $\mathrm{CO}_{2}$ puro, argônio puro ou mistura de ambos [68]. A Figura 26 apresenta uma ilustração do processo MAG.

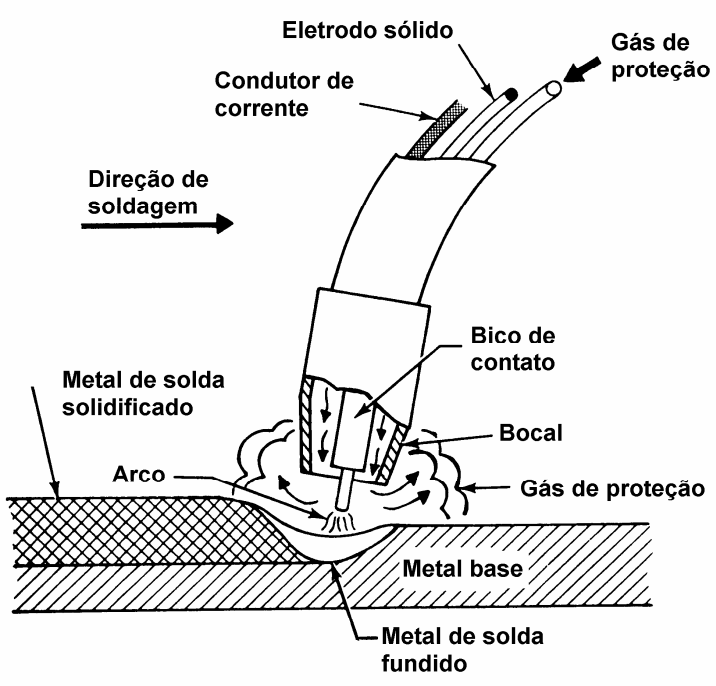

Figura 26- llustração do processo de soldagem MAG [45].

O processo de soldagem MAG-TC consiste no controle da corrente sem alteração na velocidade de avanço do eletrodo, necessitando para isto de uma fonte de soldagem específica, obtendo desta forma uma baixa energia de soldagem, fumos e respingos. A redução no índice de respingos diminui o tempo necessário para a limpeza, tanto da tocha quanto da junta soldada [69].

Diferentemente das fontes para o processo MAG, as fontes para o processo MAG-TC operam com curva característica de corrente constante, ao invés da curva de tensão constante. Deste modo, a fonte consegue alterar a corrente elétrica do arco em um curto espaço de tempo. A estabilidade do arco é mantida mesmo com variações na extensão do eletrodo e ângulo de 
soldagem, através de um controle preciso da corrente de soldagem. Desta forma elimina-se a variação da corrente para o ajuste da extensão do eletrodo, como no processo MAG, garantindo assim que não ocorram decréscimos pontuais no calor transferido [69].

A transferência metálica obtida por este processo é por curto-circuito, utilizando como gás de proteção $\mathrm{CO}_{2}$ puro ou misturas $\mathrm{Ar} / \mathrm{CO}_{2}$ [69]. A figura 27 apresenta o formato de onda utilizado no processo MAG-TC.

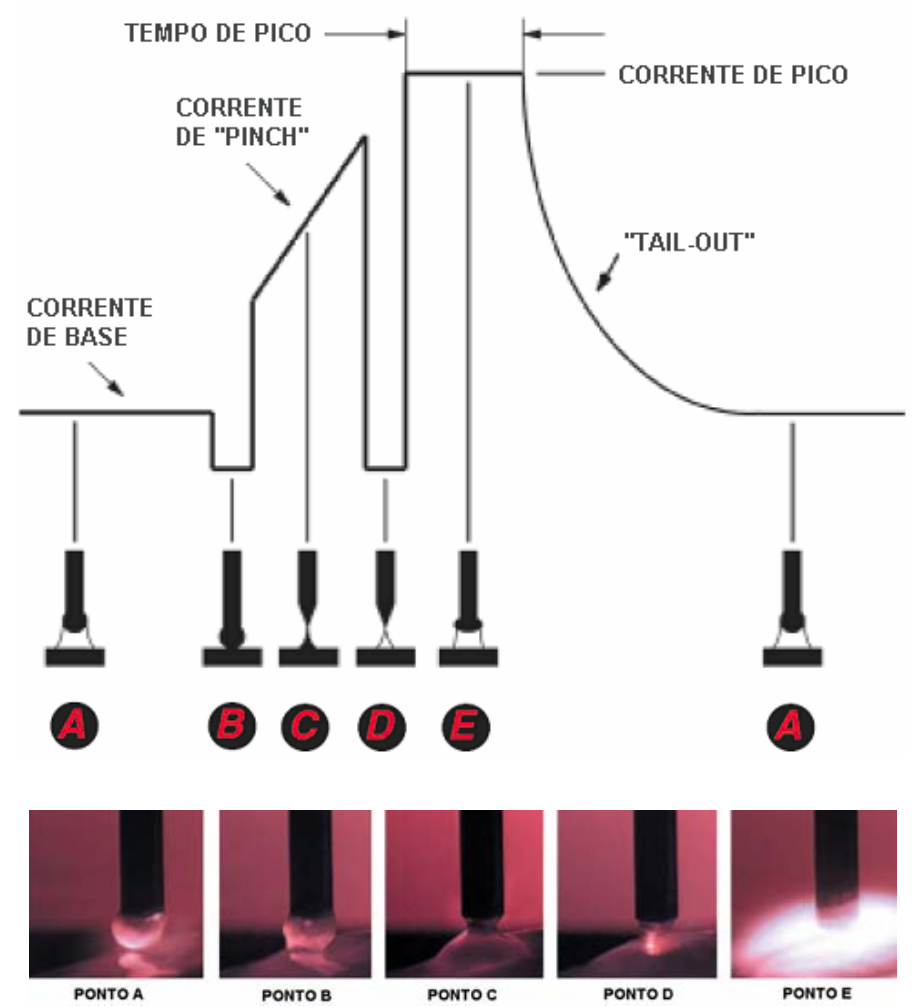

Figura 27- Formato de onda do processo MAG-TC [69].

O ponto $\mathrm{A}$ corresponde a corrente de base (50 a $100 \mathrm{~A}$ ) tendo a função manter o arco aberto e transferir calor a poça de fusão. Quando a gota formada na ponta do eletrodo toca a poça de fusão criando um curto-circuito, ponto $B$, ocorre uma queda na corrente, onde em seguida é aplicada a corrente de pinçamento da gota (pinch efffect), ponto $\mathrm{C}$, que possui a função de desprender a gota da ponta do eletrodo, depositando-a na poça de fusão.

O controle eletrônico da fonte monitora os parâmetros elétricos do arco e percebe quando a ligação líquida entre a gota que está sendo depositada e a ponta do arame vai extinguir-se, para em seguida diminuir a corrente para valores entre 45 a $50 \mathrm{~A}$, restabelecendo o arco elétrico, ponto $\mathrm{D}$. 
Após o restabelecimento do arco, ponto E, é aplicada a corrente de pico que tem por função empurrar a poça de fusão para baixo a fim de prevenir curto-circuito e aquecer a junta. A função do tail-out é controlar a taxa de decréscimo da corrente de pico para a corrente de base, atuando como um controle grosseiro da energia de soldagem.

As vantagens do uso do processo MAG-TC na soldagem do passe de raiz de tubulações, em relação à soldagem MAG, reside no fato de que o controle do curto-circuito previne a ocorrência de falta de fusão, fumos e respingos, mesmo utilizando $\mathrm{CO}_{2}$ puro como gás de proteção, proporcionando desta forma, um cordão de solda com bom acabamento e sanidade [69]. Em relação ao processo TIG, o processo MAG-TC possui velocidade de soldagem 4 vezes maior e possibilita a soldagem na posição vertical descendente [69].

Em relação ao processo ER, o processo MAG-TC apresenta vantagens principalmente em relação ao ganho de produtividade, pois não é preciso parar a soldagem para troca de consumíveis e esmerilhamento após o término do passe de raiz, pois diferentemente do processo ER o perfil do cordão de solda é plano. O perfil de acabamento do passe de raiz com eletrodos celulósicos é convexo, o que obriga a maior perda de tempo na operação de esmerilhamento [69]. A figura 28 apresenta o perfil dos cordões de solda obtidos pelos processos ER e MAG-TC. Além do perfil do cordão, o metal de solda depositado por consumíveis sólidos apresenta menor teor de hidrogênio do que o depositado com eletrodo celulósico e menor energia de soldagem [69].

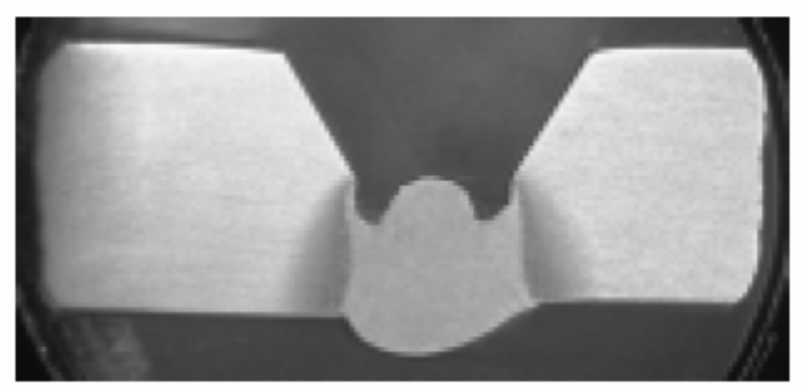

Processo de Soldagem SMAW

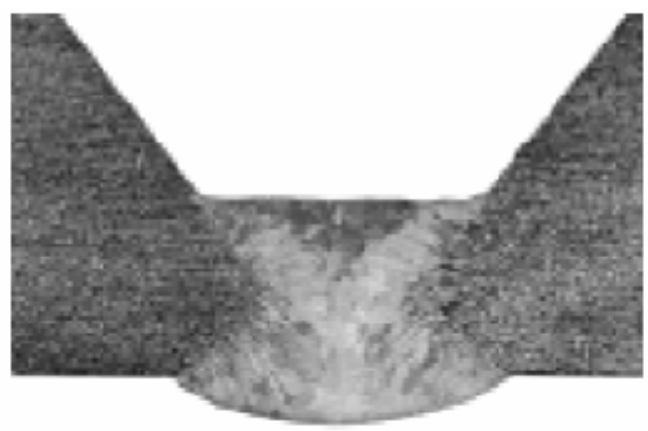

Processo de Soldagem STT

Figura 28- Perfil do cordão de solda obtido pelos processos de soldagem ER e MAG-TC [70]. 


\subsubsection{Processo AT:}

O processo de soldagem AT utiliza os mesmos equipamentos do processo MAG, diferindo apenas nas roldanas utilizadas para tracionar 0 eletrodo no alimentador e no consumível utilizado. O consumível utilizado é um tubo metálico contínuo, onde o fluxo é acondicionado no interior deste.

O fluxo possui basicamente as mesmas funções do revestimento do eletrodo revestido, podendo ou não gerar os gases necessários a proteção da poça de fusão. No caso do fluxo interno não gerar os gases necessários a proteção da poça de fusão, esta função, será realizada por um gás acondicionado em cilindros e disposto sobre a poça de fusão da mesma forma que no processo MAG. Esta variante é denominada 'com proteção gasosa' (gas-shielded), ou AT-PG [71]. A figura 29a ilustra o processo AT-PG.

No caso do fluxo interno, durante a queima, gerar os gases necessários a proteção da poça de fusão não é necessária a utilização de uma fonte de gás externa. Esta variante é denominada auto-protegida (self-shielded), ou ATAP [57]. A figura 29b ilustra o processo AT-AP.

\subsection{Consumíveis:}

Os eletrodos revestidos mais utilizados na soldagem de dutos são os do tipo celulósicos, entretanto devido ao alto teor de hidrogênio no metal de solda, para os aços acima do grau X70 é imprescindível a utilização de eletrodos básicos, ou outros processos de soldagem, tais como: MAG e AT, pois seus consumíveis apresentam baixo teor de hidrogênio [5].

Uma combinação comum é a utilização de eletrodo celulósico E6010 para a deposição do primeiro passe de raiz e em seguida o enchimento com eletrodo celulósico E9010-G ou eletrodo básico E10018-G. A razão do emprego do eletrodo E6010 reside no fato de que é o eletrodo celulósico que proporciona melhor tenacidade, frente aos outros eletrodos celulósicos. A menor resistência mecânica não terá influência no resultado final, pois a espessura do metal depositado frente à espessura da junta é pequena, sem contar o efeito da diluição, o que acabaria aumentando a resistência mecânica [57]. 


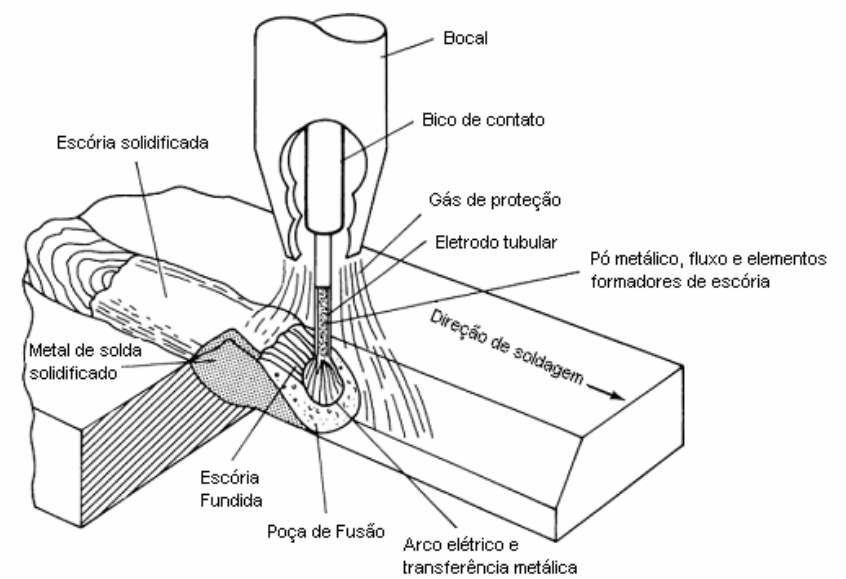

(a)

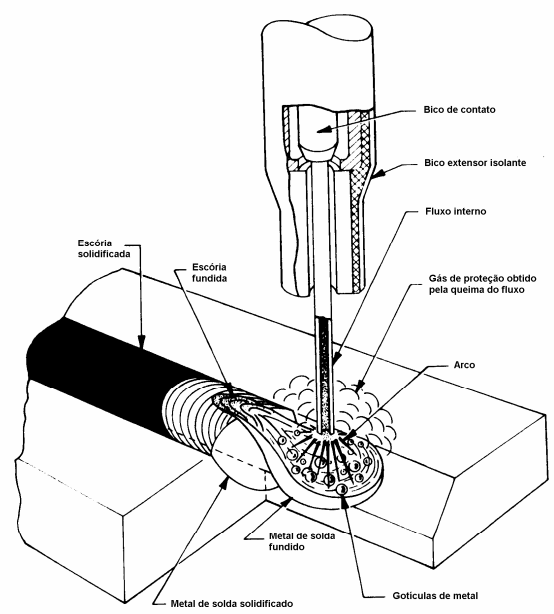

(b)

Figura 29 - (a) llustração do processo AT-PG; (b) llustração do processo AT-AP [45,71].

Ramirez [71] e Durant [37] estudaram, entre outros processos, a combinação de processos MAG-TC e AT em suas duas variantes. Fedele [72] afirma que de maneira similar a soldagem com eletrodos revestidos, é preferível utilizar eletrodos com resistência mecânica menor e maior tenacidade para a soldagem do passe de raiz. Quando requerido, o gás de proteção mais utilizado é $\mathrm{CO}_{2}$ puro, entretanto para os passes de raiz e acabamento podem ser utilizadas misturas $75 \mathrm{Ar} / 25 \mathrm{CO}_{2}$, pois nestes casos existe uma maior preocupação com a configuração geométrica do cordão.

O processo MAG-TC, por utilizar eletrodo sólido, proporciona baixo teor de hidrogênio dissolvido no metal de solda. O processo AT apresenta teor de 
hidrogênio um pouco maior do que o obtido com eletrodos sólidos, todavia menor do que o obtido com o uso de eletrodos revestidos celulósicos.

A tabela 15 apresenta os consumíveis mais utilizados na soldagem com a combinação de processos MAG-TC e AT em suas duas variantes: AT-PG e AT-AP

Tabela 15- Consumíveis utilizados na soldagem de tubos X80 com a combinação de processos MAG-TC + AT.

\begin{tabular}{|c|c|c|l|c|}
\hline Tubo X80 & Raiz & Passe Quente & Ench. E Acab. & Tipo \\
\hline Ref [37] & ER80S-G & E101T1-GM-H8 & Gas Shielded \\
\hline Ref [73] & ER70S-6 & E91T8-G & Self-Shielded \\
\hline
\end{tabular}

\subsection{Qualificação de procedimento de soldagem:}

A qualificação de um procedimento de soldagem tem como objetivo garantir que a solda executada atenda aos requisitos mecânicos do material que está sendo soldado, proporcionando assim repetibilidade e qualidade da solda produzida [73].

Para que um procedimento seja considerado qualificado, é necessário utilizar uma amostra, a qual deve ser preparada e soldada utilizando todos os parâmetros estabelecidos no procedimento que se deseja qualificar. Após a conclusão da soldagem, devem-se extrair corpos de prova que serão analisados e ensaiados. Os resultados devem ser avaliados com base em um critério de aceitação, podendo ser considerados aprovados ou não [73].

A norma API 1104 tem como finalidade estabelecer os critérios e requisitos para a execução de soldas circunferenciais de alta qualidade, em tubos e dutos, através do uso de soldadores e procedimentos qualificados [8].

\subsection{Determinação da austenita retida por saturação magnética:}

Um dos métodos utilizados para a determinação da fração volumétrica da austenita retida é através do ensaio de saturação magnética. [74] Este ensaio é baseado na medição da saturação magnética da amostra da qual se deseja medir a fração volumétrica de austenita. Como a austenita não é uma 
fase magnética, a medida de saturação magnética obtida está ligada à quantidade de austenita presente. Este método possibilita maior precisão na determinação da fração volumétrica da austenita retida, pois as amostras utilizadas representam o volume do material e não somente um plano, conforme o método de metalografia quantitativa. Outra particularidade deste método é que o mesmo detecta somente a fase austenítica, enquanto que o método de metalografia quantitativa determina a quantidade de fase MA, podendo gerar distorções nos resultados. A fim de determinar a saturação magnética de referência (com fração volumétrica de austenita retida tendendo a zero) trata-se termicamente a amostra a ser ensaiada por 1 hora a $400{ }^{\circ} \mathrm{C}$ com o intuito de eliminar a austenita retida e obter a máxima saturação magnética. Este parâmetro foi estudado por Ramírez [26] e considerado eficaz no aço X80 utilizado.

Uma das técnicas mais utilizadas neste ensaio é a da amostra vibrante, a qual permite o ensaio de amostras de tamanho reduzido. Neste tipo de ensaio a amostra é suspensa entre as peças polares de um eletroímã, na extremidade de uma haste vibrante. Quando da aplicação do campo estático pelo eletroímã, a amostra é magnetizada e associada a vibração induz um sinal nas bobinas de pick-up. Através do sinal induzido nestas bobinas, é construída a curva de magnetização do material. [74] A figura 30 apresenta um exemplo de curva de saturação magnética (magnetização) obtida por Landgraf [74] para duas amostras tratadas termicamente, a 180 e $230{ }^{\circ} \mathrm{C}$, mostrando a variação da magnetização J (saturação) em relação ao campo H aplicado.

\section{Curvas de Magnetização}

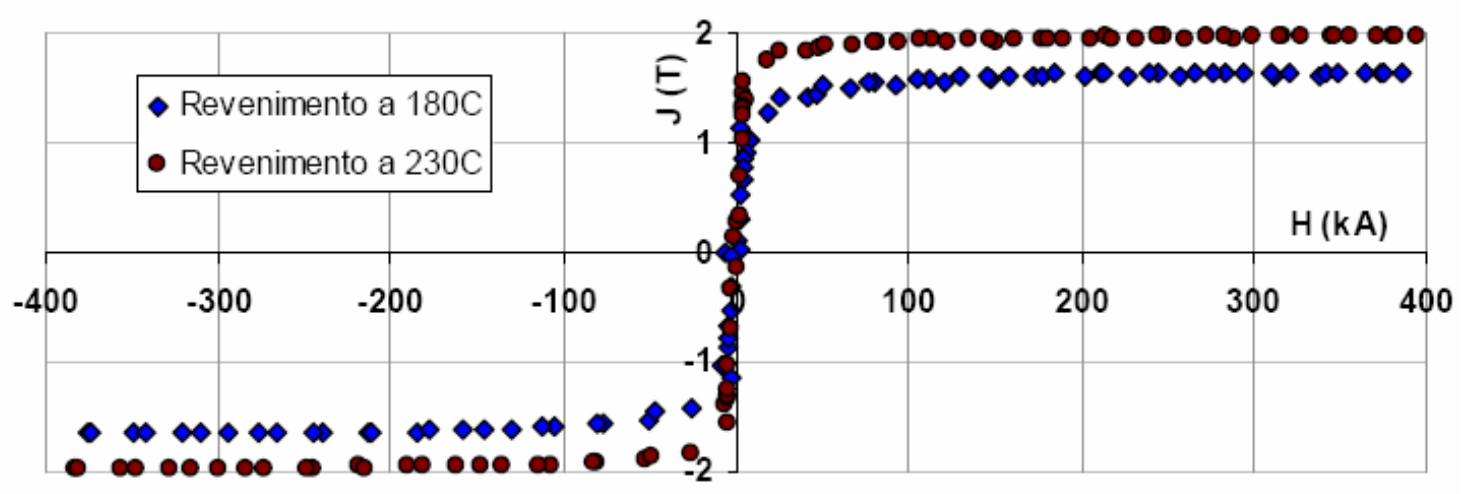


Figura 30- Exemplo de curva de magnetização para duas amostras tratadas termicamente, apresentando a variação da magnetização "Jsat" em função do campo magnético "H" aplicado. Figura baseada na ref. [74]

3.7.1 Cálculo da fração volumétrica de austenita retida:

A partir das curvas de magnetização da figura T, é possível determinar a fração volumétrica de austenita retida através da relação: [74]

$$
\% \gamma=\left(1-\frac{\text { Jsat }}{\text { Jref }}\right) \times 100
$$

Onde:

$\%$ y = fração volumétrica de austenita retida;

$\mathrm{J}=$ magnetização de saturação medida da amostra (média entre os valores dos extremos da curva);

Jref = magnetização de saturação medida da amostra tratada termicamente; 


\section{MATERIAIS E MÉTODOS:}

\subsection{Tubo API 5L X80:}

O tubo API 5L X80 utilizado foi doado pela Petróleo Brasileiro S.A. Petrobrás e produzido pela Tenaris-Confab, pelo processo UOE, com aço fornecido pela Usiminas. O diâmetro do tubo é de 20" com espessura de parede de $19 \mathrm{~mm}$. Originalmente, o tubo possuia entre 6 e $12 \mathrm{~m}$ de comprimento, entretanto o pedaço doado possui $3 \mathrm{~m}$ de comprimento.

Para a execução dos experimentos foram cortados 9 anéis, sendo $8 \mathrm{com}$ aproximadamente $300 \mathrm{~mm}$ de comprimento e 1 com $600 \mathrm{~mm}$. Os 8 anéis de $300 \mathrm{~mm}$ destinam-se a soldagem dos experimentos, sendo que cada junta é formada por 2 anéis. O anel de $600 \mathrm{~mm}$ destina-se aos testes de soldagem (levantamento inicial de parâmetros) e extração dos corpos de prova de tração (transversal e longitudinal), dureza, metalográficos e impacto entre outros.

O processo de corte dos tubos e extração dos corpos de prova, quando possível, será através de PAC (Plasma Arc Cutting) com usinagem posterior, a fim de facilitar as operações de corte. Quando não for possível o emprego do processo PAC, será utilizado corte mecânico para evitar o surgimento de ZAC's devido ao processo de corte térmico.

A tabela 16 apresenta a composição química do tubo API 5L X80 tal como recebido, realizada pelo laboratório Proaqt, conforme laudo do anexo I.

\subsection{Consumíveis de soldagem:}

Todos os eletrodos utilizados na soldagem dos anéis são fabricados nos Estados Unidos pela The Lincoln Electric Company e fornecidos pela filial brasileira Lincoln Electric do Brasil. Os gases de proteção utilizados são fabricados e fornecidos para a Lincoln Electric do Brasil pela Air Liquide do Brasil.

Todos os consumíveis utilizados seguem as respectivas especificações AWS. 
Tabela 16- Composição química do tubo API $5 \mathrm{~L}$ X80, comparado com os valores especificados pela norma API $5 \mathrm{~L}$.

\begin{tabular}{|c|c|c|}
\hline $\begin{array}{l}\text { Elementos de } \\
\text { ligas }\end{array}$ & $\begin{array}{l}\text { Análise química do Aço } \\
\text { API } 5 \mathrm{~L} \text { X80 }\end{array}$ & $\begin{array}{c}\text { Classificação do tubo segundo a } \\
\text { Norma API 5L }\end{array}$ \\
\hline C & 0,051 & $\leq 0,22$ \\
\hline $\mathrm{Mn}$ & 1,805 & $\leq 1,85$ \\
\hline $\mathrm{Si}$ & 0,183 & $\mathrm{NE}^{(1)}$ \\
\hline$P$ & 0,019 & 0,025 máx \\
\hline$S$ & 0,004 & 0,015 máx \\
\hline $\mathrm{Cr}$ & 0,161 & $\mathrm{NE}^{(1)}$ \\
\hline $\mathrm{Ni}$ & 0,013 & $\mathrm{NE}^{(1)}$ \\
\hline Mo & 0,207 & $\mathrm{NE}^{(1)}$ \\
\hline $\mathrm{Al}$ & 0,029 & $\mathrm{NE}^{(1)}$ \\
\hline $\mathrm{Cu}$ & 0,012 & $\mathrm{NE}^{(1)}$ \\
\hline $\mathrm{Ti}$ & 0,014 & \multirow{3}{*}{$\leq 0,15$} \\
\hline V & 0,021 & \\
\hline $\mathrm{Nb}$ & 0,0658 & \\
\hline$B$ & 0,0003 & $\mathrm{NE}^{(1)}$ \\
\hline $\mathrm{Ca}$ & 0,0031 & $\mathrm{NE}^{(1)}$ \\
\hline Co & 0,002 & $\mathrm{NE}^{(1)}$ \\
\hline $\mathrm{Pb}$ & 0,0007 & $\mathrm{NE}^{(1)}$ \\
\hline $\mathrm{Sb}$ & 0,0031 & $\mathrm{NE}^{(1)}$ \\
\hline Sn & 0,001 & $\mathrm{NE}^{(1)}$ \\
\hline $\mathrm{Ta}$ & 0,0095 & $\mathrm{NE}^{(1)}$ \\
\hline W & 0,0013 & $\mathrm{NE}^{(1)}$ \\
\hline $\mathrm{Zn}$ & 0,0033 & $\mathrm{NE}^{(1)}$ \\
\hline $\mathrm{Zr}$ & 0,0018 & $\mathrm{NE}^{(1)}$ \\
\hline $\mathrm{Fe}$ & 97,39 & $\mathrm{NE}^{(1)}$ \\
\hline $\mathrm{CE}_{\| \mathrm{W}}{ }^{(2)}$ & 0,43 & $\mathrm{NE}^{(1)}$ \\
\hline $\mathrm{P}_{\mathrm{cm}}{ }^{(3)}$ & 0,17 & $\mathrm{NE}^{(1)}$ \\
\hline
\end{tabular}

Notas: 1) $\mathrm{NE}=$ não especificado, 2) Carbono equivalente segundo fórmula do IIW; 3)

Parâmetro do carbono equivalente. 


\subsubsection{Eletrodo sólido:}

Para a soldagem do passe de raiz com o processo MAG-TC nos experimentos, foi utilizado o eletrodo sólido de classificação ER80S-G, especificado pela norma AWS A5.28 "Specification For Low-Alloy Steel Electrodes and Rods for Gas Shielded Arc Welding" [6]. Segundo o fabricante, este eletrodo atende os requisitos de propriedades mecânicas do tubo X80 [75].

$O$ gás de proteção utilizado foi $\mathrm{CO}_{2}$ puro, pois este é o gás de proteção de menor custo e o indicado para a soldagem com o processo MAG-TC, segundo o fabricante. Como não possui revestimento ou fluxo interno, este consumível deposita um metal de solda de baixíssimo teor de hidrogênio. As únicas fontes de hidrogênio disponíveis são: o gás de proteção e/ou óxidos e hidrocarbonetos presentes no metal de base.

A tabela 17 apresenta as propriedades mecânicas do eletrodo sólido utilizado conforme o exigido pela especificação AWS, o informado pelo catálogo do fabricante e pelo certificado do lote utilizado (Anexo II). Deve-se salientar que os eletrodos utilizados devem atender ao limite de escoamento mínimo do tubo.

Tabela 17- Propriedades mecânicas mínimas do consumível utilizado, segundo a especificação AWS, catálogo do fabricante e certificado do lote utilizado $[6,75]$.

\begin{tabular}{|c|c|c|c|}
\hline & Especificação AWS & Catálogo Fabricante & Certificado \\
\hline Consumível & ER80S-G & ER80S-G & ER80S-G \\
\hline Especificação AWS & A5.28 & A5.28 & A5.28 \\
\hline Lim. Resistência mín & $\begin{array}{c}80 \mathrm{ksi} \\
(552 \mathrm{MPa})\end{array}$ & $\begin{array}{c}90 \text { a } 100 \mathrm{ksi} \\
(621 \text { a } 690 \mathrm{MPa})\end{array}$ & $\begin{array}{c}103 \mathrm{ksi} \\
(710 \mathrm{MPa})\end{array}$ \\
\hline Lim. Escoamento mín & $\mathrm{N} / \mathrm{A}$ & $\begin{array}{c}85 \text { a } 90 \mathrm{ksi} \\
(586 \text { a } 621 \mathrm{MPa})\end{array}$ & $\begin{array}{c}89 \mathrm{ksi} \\
(614 \mathrm{MPa})\end{array}$ \\
\hline Alongamento \% & N/A & 22 a 24 & 22 \\
\hline Charpy-V @ -29 ${ }^{\circ} \mathrm{C}(\mathrm{J})$ & $\mathrm{N} / \mathrm{A}$ & 27 a 54 & $101^{*}$ \\
\hline
\end{tabular}

${ }^{*}$ Referente a soldagem com mistura gasosa $80 \mathrm{Ar} / 20 \mathrm{CO}_{2}$, utilizada na emissão do certificado. 
A tabela 18 apresenta a composição química do metal de solda depositado do eletrodo sólido utilizado, conforme a especificação AWS, o catálogo do fabricante e pelo certificado do lote utilizado (Anexo 02).

Tábela 18- Composição química do metal de solda depositado, conforme requerido pela especificação AWS e o informado pelo catálogo do fabricante $[6,75]$.

\begin{tabular}{|c|c|c|c|}
\hline & Especificação AWS & Catálogo Fabricante & Certificado \\
\hline Consumível & ER80S-G & ER80S-G & ER80S-G \\
\hline Especificação AWS & A5.28 & A5.28 & A5.28 \\
\hline$\% \mathrm{~N}$ & $\mathrm{~N} / \mathrm{A}$ & 0,05 a 0,15 & 0,10 \\
\hline$\% \mathrm{Mn}$ & $\mathrm{N} / \mathrm{A}$ & 1,40 a 1,60 & 1,70 \\
\hline$\% \mathrm{Si}$ & $\mathrm{N} / \mathrm{A}$ & 0,40 a 0,70 & 0,59 \\
\hline$\% \mathrm{Cu}$ & $\mathrm{N} / \mathrm{A}$ & 0,20 & 0,211 \\
\hline$\% \mathrm{~S}$ & $\mathrm{~N} / \mathrm{A}$ & 0,02 & 0,009 \\
\hline$\% \mathrm{P}$ & $\mathrm{N} / \mathrm{A}$ & 0,02 & 0,014 \\
\hline$\% \mathrm{Ni}$ & $\mathrm{N} / \mathrm{A}$ & $\mathrm{NE}$ & 0,02 \\
\hline$\% \mathrm{Mo}$ & $\mathrm{N} / \mathrm{A}$ & 0,45 \\
\hline$\% \mathrm{NE}$ & $\mathrm{NE}$ & 0,003 \\
\hline$\% \mathrm{Nr}$ & $\mathrm{N} / \mathrm{A}$ & $\mathrm{NE}$ & 0,02 \\
\hline $\mathrm{H}_{2} \mathrm{ml} / 100 \mathrm{~g}$ máx & & & 1,4 \\
\hline
\end{tabular}

\subsubsection{Eletrodos tubulares:}

Para os passes de enchimento e acabamento das soldas dos experimentos 1 e 2 foram utilizados eletrodos tubulares em suas duas variantes, respectivamente: sem gás de proteção (self-shielded) e com gás de proteção (gas shielded).

O eletrodo tubular utilizado no experimento 1 segue a especificação AWS A5.29, de classificação E91T8-G, atendendo também os requisitos de resistência mecânica do tubo X80. Este tipo de eletrodo é do tipo autoprotegido, ou seja, a queima do fluxo durante a soldagem produz os gases necessários à proteção da poça de fusão. $O$ teor máximo de hidrogênio

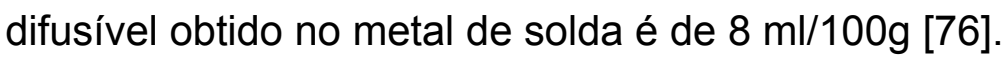


O eletrodo tubular utilizado no experimento 2 também segue a especificação AWS A.5.29 "Specification for Low-Alloy Electrodes for Flux Cored Arc Welding", de classificação E101T1-GM-H8, o qual atende os requisitos mecânicos do tubo $X 80$. Este eletrodo possui fluxo interno do tipo rutílico, com teor máximo de hidrogênio difusível de $8 \mathrm{ml} / 100 \mathrm{~g}$. O gás de proteção consiste de mistura $75 \mathrm{Ar} / 25 \mathrm{CO}_{2}$. A posição de soldagem é vertical ascendente [75].

A tabela 19 apresenta as propriedades mecânicas dos eletrodos tubulares utilizados conforme o exigido pela especificação AWS, o informado pelo catálogo do fabricante $[75,76]$ e pelo certificado do lote utilizado (Anexos III e IV). Deve-se salientar que os eletrodos utilizados devem atender ao limite de escoamento mínimo do tubo.

Tabela 19- Propriedades mecânicas mínimas dos consumíveis utilizados, segundo a especificação AWS, catálogo do fabricante e certificado do lote utilizado $[7,75,76]$.

\begin{tabular}{|c|c|c|c|c|c|c|}
\hline \multirow[b]{2}{*}{ Consumível } & \multicolumn{2}{|c|}{ Especificação AWS } & \multicolumn{2}{|c|}{ Catálogo Fabricante } & \multicolumn{2}{|c|}{ Certificado } \\
\hline & E101T1-GM-H8 & E91T8-G & E101T1-GM-H8 & E91T8-G & E101T1-GM-H8 & E91T8-G \\
\hline Esp. AWS & A5.29 & A5.29 & A5.29 & A5.29 & A5.29 & A5.29 \\
\hline LR mín & $\begin{array}{c}100 \text { a } 120 \mathrm{ksi} \\
(690 \text { a } 827 \mathrm{MPa})\end{array}$ & $\begin{array}{c}90 \text { a } 110 \mathrm{ksi} \\
(621 \text { a } 758 \mathrm{MPa})\end{array}$ & $\begin{array}{c}106 \text { a } 110 \mathrm{ksi} \\
(731 \text { a } 758 \mathrm{MPa})\end{array}$ & $\begin{array}{c}94 \text { a } 99 \mathrm{ksi} \\
(648 \text { a } 683 \mathrm{MPa})\end{array}$ & $\begin{array}{c}104 \mathrm{ksi} \\
(717 \mathrm{MPa})\end{array}$ & $\begin{array}{c}98 \mathrm{ksi} \\
(676 \mathrm{MPa})\end{array}$ \\
\hline LE mín & $\begin{array}{c}88 \mathrm{ksi} \\
(607 \mathrm{MPa})\end{array}$ & $\begin{array}{c}78 \mathrm{ksi} \\
(538 \mathrm{MPa})\end{array}$ & $\begin{array}{c}99 \text { a } 106 \mathrm{ksi} \\
(683 \text { a } 731 \mathrm{MPa})\end{array}$ & $\begin{array}{c}81 \text { a } 86 \mathrm{ksi} \\
(558 \text { a } 593 \mathrm{MPa})\end{array}$ & $\begin{array}{c}98 \mathrm{ksi} \\
(676 \mathrm{MPa})\end{array}$ & $\begin{array}{c}87 \mathrm{ksi} \\
(600 \mathrm{MPa})\end{array}$ \\
\hline Along. (\%) & 16 & 17 & 21 a 24 & 25 a 27 & 22 & 25 \\
\hline $\begin{array}{l}\text { Charpy-V } \\
@-29^{\circ} \mathrm{C}(\mathrm{J})\end{array}$ & $\mathrm{N} / \mathrm{A}$ & $\mathrm{N} / \mathrm{A}$ & 54 a 64 & 50 & 53 & 96 \\
\hline $\begin{array}{l}\text { Charpy-V } \\
@-46^{\circ} \mathrm{C}(\mathrm{J})\end{array}$ & N/A & N/A & 46 a 49 & 44 & NE & NE \\
\hline
\end{tabular}

A tabela 20 apresenta a composição química do metal de solda depositado dos eletrodos tubulares utilizados, bem como o teor máximo de hidrogênio difusível, conforme a especificação AWS, o catálogo do fabricante e o certificado do lote utilizado (Anexos III e IV). 
Tábela 20-Composição química do metal de solda depositado, conforme requerido pela especificação AWS, catálogo do fabricante e o certificado do lote utilizado $[7,75,76]$.

\begin{tabular}{|c|c|c|c|c|c|c|}
\hline & \multicolumn{2}{|c|}{ Especificação AWS } & \multicolumn{2}{c|}{ Catálogo Fabricante } & \multicolumn{2}{c|}{ Certificado } \\
\hline Consumível & E101T1-GM-H8 & E91T8-G & E101T1-GM-H8 & E91T8-G & E101T1-GM-H8 & E91T8-G \\
\hline Especificação AWS & A5.29 & A5.29 & A5.29 & A5.29 & A5.29 & A5.29 \\
\hline$\% C$ & N/A & N/A & 0,03 a 0,04 & 0,05 & 0,042 & 0,04 \\
\hline$\% M n$ & 1,75 & 1,75 & 1,68 a 1,75 & 2,13 & 1,61 & 2,31 \\
\hline$\% S i$ & 0,80 & 0,80 & 0,37 a 0,40 & 0,25 & 0,34 & 0,26 \\
\hline$\% N i$ & 0,50 & 0,50 & 1,01 a 1,03 & 0,79 & 1,01 & 0,84 \\
\hline$\% C r$ & 0,30 & 0,30 & 0,07 a 0,11 & 0,02 & 0,03 & 0,04 \\
\hline$\% M o$ & 0,20 & 0,20 & 0,26 a 0,29 & 0,01 & 0,27 & 0,01 \\
\hline$\% V$ & 0,10 & 0,10 & 0,022 a 0,023 & 0,01 & 0,02 & - \\
\hline$\% A l$ & N/A & 1,80 & N/A & 1,13 & 0,01 & 1,1 \\
\hline$\% C u$ & N/A & - & N/A & - & 0,03 & - \\
\hline$\% S$ máx & 0,03 & 0,03 & 0,008 a 0,012 & 0,002 & 0,01 & - \\
\hline$\% P$ máx & 0,03 & 0,03 & 0,015 a 0,017 & 0,11 & 0,02 & 0,01 \\
\hline $\mathrm{H}_{2}$ ml/100g máx & 8 & N/A & 4 a 7 & N/A & 6,7 & 6,8 \\
\hline
\end{tabular}

\subsection{Execução das soldagens:}

\subsubsection{Experimentos:}

Os 8 anéis foram montados dois a dois a fim de formar 4 juntas a serem soldadas. Duas destas juntas foram reservadas para a soldagem dos corpos de prova para os ensaios mecânicos, químicos e metalográficos, e as duas restantes para extração dos corpos de prova para o ensaio de impacto. Estas 4 juntas foram denominadas tubo 1 e tubo 2 , e tubo $1 \mathrm{~A}$ e $2 \mathrm{~A}$, respectivamente.

Os tubos 1 e $1 \mathrm{~A}$ representam a combinação de processos do experimento 1 e os tubos 2 e $2 \mathrm{~A}$ representam a combinação de processos do experimento 2 .

Os tubos $1 \mathrm{~A}$ e $2 \mathrm{~A}$ foram soldados utilizando os mesmos parâmetros de seus respectivos pares, tubo 1 e 2 , respectivamente. A tabela 21 apresenta os experimentos e os respectivos nomes dos corpos de prova, bem como a finalidade dos mesmos.

A soldagem dos tubos foi executada pela Lincoln Electric do Brasil com o acompanhamento do mestrando. 
Tabela 21 - Experimentos, finalidades e identificação dos corpos de prova / junta soldada.

\begin{tabular}{|c|c|c|c|c|c|}
\hline $\begin{array}{l}\text { Identificação } \\
\text { da junta / cp }\end{array}$ & Sigla & Experimento & $\begin{array}{l}\text { Combinação } \\
\text { de processos }\end{array}$ & Finalidade & Dimensões \\
\hline Tubo 01 & T1 & 1 & $\begin{array}{c}\text { MAG-TC + AT- } \\
\text { AP }\end{array}$ & \multirow{2}{*}{$\begin{array}{c}\text { Extração cp's para } \\
\text { ensaios mecânicos, } \\
\text { químicos e } \\
\text { metalográficos }\end{array}$} & \multirow{2}{*}{$\begin{array}{l}2 \text { anéis de } 300 \mathrm{~mm} \\
\text { de comprimento, } \\
\text { totalizando } 600 \mathrm{~mm}\end{array}$} \\
\hline Tubo 02 & T2 & 2 & $\begin{array}{c}\text { MAG-TC + AT- } \\
\text { PG }\end{array}$ & & \\
\hline Tubo 01A & T1A & 1 & $\begin{array}{c}\text { MAG-TC + AT- } \\
\text { AP }\end{array}$ & \multirow{2}{*}{$\begin{array}{l}\text { Extração cp's para } \\
\text { ensaio de impacto }\end{array}$} & \multirow{2}{*}{$\begin{array}{l}2 \text { anéis de } 300 \mathrm{~mm} \\
\text { de comprimento, } \\
\text { totalizando } 600 \mathrm{~mm}\end{array}$} \\
\hline Tubo 02A & $\mathrm{T} 2 \mathrm{~A}$ & 2 & $\begin{array}{c}\text { MAG-TC + AT- } \\
\text { PG }\end{array}$ & & \\
\hline
\end{tabular}

\subsubsection{Processos de soldagem:}

\subsubsection{Norma API 1104:}

Todos os experimentos realizados, além do estudo da morfologia da ZAC, microestrutura e propriedades mecânicas, visam à qualificação de um procedimento de soldagem de acordo com a norma API 1104 "Welding of Pipelines and Related Facilities" [8].

Os ensaios requeridos para a qualificação de um procedimento de soldagem, de acordo com a norma API 1104 para tubos com diâmetro de até 20" são: dobramento lateral; tração; nick-break. Para o ensaio de dobramento lateral são requeridos 8 corpos de prova, enquanto que para os ensaios de tração e nick-break são necessários 4 corpos de prova para cada um, totalizando 16 corpos de prova.

Antes, durante e após a conclusão da soldagem dos tubos foi executado o ensaio visual de solda, a fim de verificar a sanidade de cada junta soldada.

Os corpos de prova foram extraídos das regiões indicadas pela norma API 1104. A figura 31 apresenta as regiões de extração dos corpos de prova.

Estas regiões indicadas pela API 1104 foram identificadas como quadrante, logo cada junta soldada possui 4 quadrantes. A figura 32 apresenta a identificação adotada, em relação à respectiva localização. 


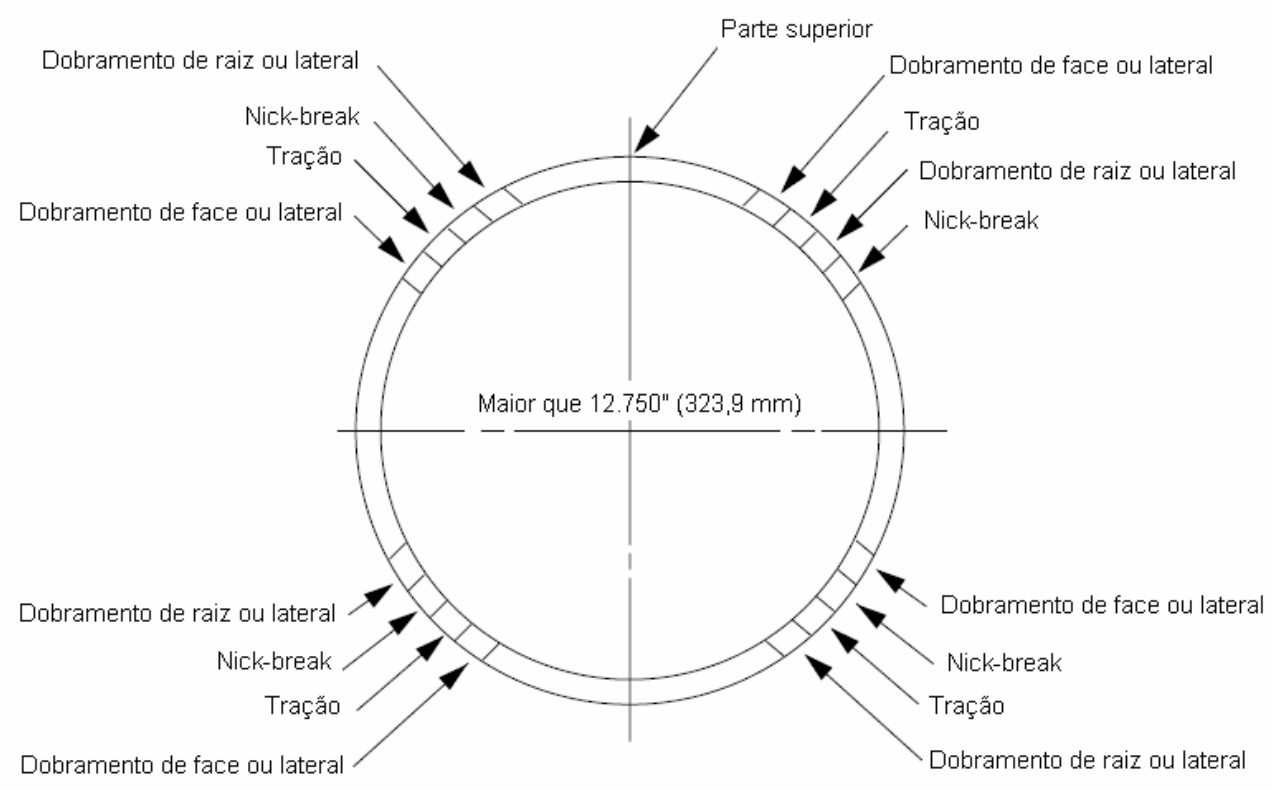

Figura 31- Região de extração dos corpos de prova, conforme API 1104 [7].

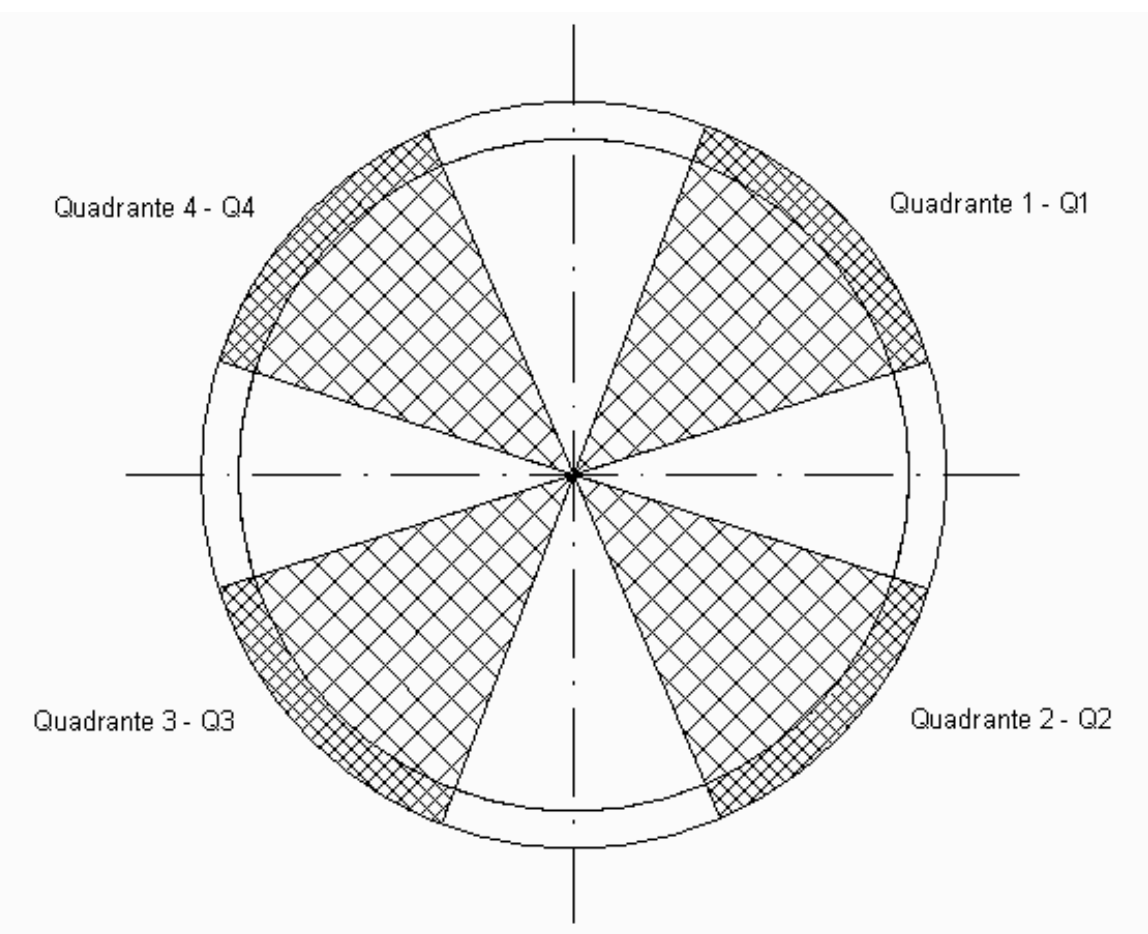

Figura 32- Identificação e localização dos quadrantes, baseado na API 1104 [7]. 


\subsubsection{Critérios de aceitação:}

O critério de aceitação adotado foi conforme o especificado na norma API 1104.

Os corpos de prova do ensaio de tração para serem considerados aprovados devem satisfazer as seguintes condições:

1. Se houver rompimento fora da junta soldada, o limite de ruptura deve atender o limite de resistência mínimo da especificação do material do tubo.

2. Se houver rompimento na junta soldada, o limite de ruptura deve atender o limite de resistência mínimo da especificação do material do tubo, e ainda: não apresentar poros com dimensões maiores que 1,6 mm com a somatória da área não excedendo $2 \%$ da área da fratura; Inclusões de escória não devem possuir mais que 0,8 $\mathrm{mm}$ de espessura ou mais que $3 \mathrm{~mm}$ de comprimento, com separação mínima de 13 mm entre inclusões adjacentes.

Os corpos de prova do ensaio de dobramento lateral, para serem considerados aprovados, devem satisfazer as seguintes condições:

1. Se não houver trincas ou se estas forem menores que $3 \mathrm{~mm}$ em qualquer direção desde que presentes no metal de solda ou entre o metal de solda e a zona de fusão após o dobramento.

2. Se não houver trincas ou se estas forem menores que $6 \mathrm{~mm}$ nas bordas do corpo de prova originadas no lado tracionado, medida em qualquer direção.

Os corpos de prova do ensaio nick-break para serem considerados aprovados devem satisfazer as seguintes condições:

1. Se houver poros, estes não devem possuir dimensões maiores que $1,6 \mathrm{~mm}$ e a somatória das áreas não devem exceder $2 \%$ da área da fratura.

2. Se houver inclusões de escória, estas não devem possuir mais que $0,8 \mathrm{~mm}$ de espessura ou mais que $3 \mathrm{~mm}$ de comprimento, com separação mínima de $13 \mathrm{~mm}$ entre inclusões adjacentes. 


\subsubsection{Equipamentos de soldagem:}

Os equipamentos de soldagem utilizados em todas as soldas são fabricados nos Estados Unidos, pela The Lincoln Electric Company.

O equipamento utilizado para soldagem do passe de raiz empregando 0 processo MAG-TC e os passes de enchimento do processo AT-PG, consiste em uma fonte de soldagem modelo Powerwave 455M/STT do tipo inversor, corrente contínua, curva característica do tipo tensão constante, alimentador de arame Powerfeed 10M com roldanas lisas (MAG-TC) e recartilhadas (AT-PG).

O equipamento utilizado para soldagem dos passes de enchimento empregando o processo AT-AP consiste em uma fonte de soldagem Invertec V-350 Pipe, do tipo inversora e corrente contínua, com curva característica do tipo tensão constante; alimentador de arame LN-23P.

\subsubsection{Variáveis:}

As variáveis estudadas foram: a combinação de processos MAG-TC e AT em suas duas variantes (com gás de proteção e auto-protegido) em conjunto com seus respectivos consumíveis. A geometria do chanfro, a temperatura de pré-aquecimento e interpasse foram fixas para ambos anéis. A tabela 22 apresenta as variáveis estudadas por experimento.

Tábela 22- Tabela de variáveis estudadas.

\begin{tabular}{|c|c|c|}
\hline Experimento & Variáveis & Fixo \\
\hline 1 & Combinação: MAG-TC + AT-AP & $\begin{array}{c}\text { Geometria do chanfro } \\
\text { Pré-aquecimento }\end{array}$ \\
\hline 2 & Combinação: MAG-TC + AT-PG & Interpasse \\
\hline
\end{tabular}

\subsubsection{Procedimento de soldagem:}

Os anéis de tubo X80 foram soldados com dois procedimentos de soldagem elaborados de acordo com a norma API 1104, baseando-se no item 5.2 da referida norma, visando sua qualificação. Estes procedimentos encontram-se no anexo V. Um resumo dos parâmetros está apresentado nas tabelas 23 e 24 , a seguir. 
Tábela 23-Resumo dos parâmetros de soldagem empregados para o tubo 1.

\begin{tabular}{|c|c|c|c|c|c|c|c|}
\hline Quadrante & Camada & $\begin{array}{c}\mathrm{T}_{\text {pré }} \\
\left({ }^{\circ} \mathrm{C}\right)\end{array}$ & $\begin{array}{c}\mathrm{T}_{\text {interpasse }} \\
\left({ }^{\circ} \mathrm{C}\right)\end{array}$ & $\begin{array}{c}\text { Corrente } \\
(\mathrm{A})\end{array}$ & $\begin{array}{c}\text { Tensão } \\
(\mathrm{V})\end{array}$ & $\begin{array}{c}\text { Velocidade } \\
(\mathrm{cm} / \mathrm{s})\end{array}$ & $\begin{array}{c}\mathrm{E}_{\text {soldagem }} \\
(\mathrm{J} / \mathrm{cm})\end{array}$ \\
\hline \multirow{5}{*}{1} & 1 & 155,3 & 178,0 & 127,2 & 18,2 & 0,87 & 1995,0 \\
\cline { 2 - 8 } & 2 & 175,3 & 209,3 & 257,8 & 20,9 & 0,88 & 4581,5 \\
\cline { 2 - 8 } & 3 & 172,7 & 205,0 & 253,8 & 18,4 & 1,01 & 3483,9 \\
\cline { 2 - 8 } & 4 & 172,7 & 224,3 & 238,6 & 18,4 & 0,81 & 4059,8 \\
\cline { 2 - 8 } & 5 & 170,3 & 194,0 & 250,4 & 18,3 & 0,62 & 5566,2 \\
\hline
\end{tabular}

\begin{tabular}{|c|c|c|c|c|c|c|c|}
\hline Quadrante & Camada & $\begin{array}{c}\mathrm{T}_{\text {pré }} \\
\left({ }^{\circ} \mathrm{C}\right)\end{array}$ & $\begin{array}{c}\mathrm{T}_{\text {interpasse }} \\
\left({ }^{\circ} \mathrm{C}\right)\end{array}$ & $\begin{array}{c}\text { Corrente } \\
(\mathrm{A})\end{array}$ & $\begin{array}{c}\text { Tensão } \\
(\mathrm{V})\end{array}$ & $\begin{array}{c}\text { Velocidade } \\
(\mathrm{cm} / \mathrm{s})\end{array}$ & $\begin{array}{c}\mathrm{E}_{\text {soldagem }} \\
(\mathrm{J} / \mathrm{cm})\end{array}$ \\
\hline \multirow{5}{*}{2} & 1 & 178,0 & 161,7 & 133,6 & 17,6 & 0,80 & 2206,6 \\
\cline { 2 - 8 } & 2 & 168,3 & 223,3 & 226,2 & 20,9 & 0,79 & 4521,1 \\
\cline { 2 - 8 } & 3 & 160,0 & 212,0 & 250,6 & 18,3 & 1,03 & 3326,3 \\
\cline { 2 - 8 } & 4 & 158,7 & 182,0 & 232,4 & 19,0 & 0,68 & 4904,0 \\
\cline { 2 - 8 } & 5 & 173,7 & 167,0 & 220,6 & 18,8 & 0,79 & 3953,9 \\
\hline
\end{tabular}

\begin{tabular}{|c|c|c|c|c|c|c|c|}
\hline Quadrante & Camada & $\begin{array}{c}\mathrm{T}_{\text {pré }} \\
\left({ }^{\circ} \mathrm{C}\right)\end{array}$ & $\begin{array}{c}\mathrm{T}_{\text {interpasse }} \\
\left({ }^{\circ} \mathrm{C}\right)\end{array}$ & $\begin{array}{c}\text { Corrente } \\
(\mathrm{A})\end{array}$ & $\begin{array}{c}\text { Tensão } \\
(\mathrm{V})\end{array}$ & $\begin{array}{c}\text { Velocidade } \\
(\mathrm{cm} / \mathrm{s})\end{array}$ & $\begin{array}{c}\mathrm{E}_{\text {soldagem }} \\
(\mathrm{J} / \mathrm{cm})\end{array}$ \\
\hline \multirow{6}{*}{3} & 1 & 159,3 & 212,7 & 123,8 & 18,5 & 0,89 & 1921,4 \\
\cline { 2 - 8 } & 2 & 177,7 & 227,0 & 256,0 & 20,9 & 0,90 & 4447,3 \\
\cline { 2 - 8 } & 3 & 178,3 & 196,7 & 256,8 & 18,4 & 0,88 & 4026,6 \\
\cline { 2 - 8 } & 4 & 170,0 & 160,0 & 216,0 & 18,3 & 0,77 & 3856,3 \\
\cline { 2 - 8 } & 5 & 160,3 & 181,0 & 249,0 & 18,9 & 0,79 & 4486,8 \\
\cline { 2 - 8 } & 7 & 172,7 & 193,3 & 256,6 & 18,9 & 1,09 & 3332,6 \\
\cline { 2 - 8 } & 8 & 156,3 & 168,3 & 236,0 & 19,0 & 1,05 & 3206,3 \\
\hline
\end{tabular}

\begin{tabular}{|c|c|c|c|c|c|c|c|}
\hline Quadrante & Camada & $\begin{array}{c}\mathrm{T}_{\text {pré }} \\
\left({ }^{\circ} \mathrm{C}\right)\end{array}$ & $\begin{array}{c}\mathrm{T}_{\text {interpasse }} \\
\left({ }^{\circ} \mathrm{C}\right)\end{array}$ & $\begin{array}{c}\text { Corrente } \\
(\mathrm{A})\end{array}$ & $\begin{array}{c}\text { Tensão } \\
(\mathrm{V})\end{array}$ & $\begin{array}{c}\text { Velocidade } \\
(\mathrm{cm} / \mathrm{s})\end{array}$ & $\begin{array}{c}\mathrm{E}_{\text {soldagem }} \\
(\mathrm{J} / \mathrm{cm})\end{array}$ \\
\hline \multirow{6}{*}{4} & 1 & 181,7 & 165,3 & 136,2 & 17,1 & 0,71 & 2469,9 \\
\cline { 2 - 8 } & 2 & 173,7 & 202,7 & 224,0 & 20,9 & 0,93 & 3757,2 \\
\cline { 2 - 8 } & 3 & 173,7 & 210,7 & 250,6 & 20,9 & 1,38 & 2852,3 \\
\cline { 2 - 8 } & 4 & 161,7 & 186,0 & 252,6 & 20,9 & 1,01 & 3934,3 \\
\cline { 2 - 8 } & 5 & 182,7 & 204,7 & 261,4 & 20,9 & 1,21 & 3392,8 \\
\cline { 2 - 8 } & 7 & 167,7 & 182,7 & 269,0 & 20,9 & 1,03 & 4078,4 \\
\cline { 2 - 8 } & 8 & 157,0 & 167,3 & 251,8 & 20,9 & 1,02 & 3867,8 \\
\hline
\end{tabular}

Nota: a eficiência de transferência de calor para o processo de soldagem com eletrodo tubular foi admitido como sendo igual a 0,75 . 
Tábela 24-Resumo dos parâmetros de soldagem empregados para o tubo 2.

\begin{tabular}{|c|c|c|c|c|c|c|c|}
\hline Quadrante & Camada & $\begin{array}{c}\mathrm{T}_{\text {pré }} \\
\left({ }^{\circ} \mathrm{C}\right)\end{array}$ & $\begin{array}{c}\mathrm{T}_{\text {interpasse }} \\
\left({ }^{\circ} \mathrm{C}\right)\end{array}$ & $\begin{array}{c}\text { Corrente } \\
(\mathrm{A})\end{array}$ & $\begin{array}{c}\text { Tensão } \\
(\mathrm{V})\end{array}$ & $\begin{array}{c}\text { Velocidade } \\
(\mathrm{cm} / \mathrm{s})\end{array}$ & $\begin{array}{c}\mathrm{E}_{\text {soldagem }} \\
(\mathrm{J} / \mathrm{cm})\end{array}$ \\
\hline \multirow{6}{*}{1} & 1 & 152,0 & 192,7 & 121,4 & 18,2 & 0,81 & 2043,1 \\
\cline { 2 - 8 } & 2 & 174,0 & 222,7 & 146,6 & 23,4 & 0,92 & 2790,6 \\
\cline { 2 - 8 } & 3 & 171,7 & 235,0 & 149,0 & 23,5 & 0,65 & 4041,0 \\
\cline { 2 - 8 } & 4 & 111,0 & 175,0 & 158,2 & 23,5 & 1,05 & 2659,4 \\
\cline { 2 - 8 } & 5 & 155,7 & 192,7 & 150,8 & 23,4 & 0,83 & 3208,3 \\
\cline { 2 - 8 } & 6 & 161,7 & 175,3 & 154,2 & 23,4 & 0,84 & 3243,3 \\
\hline
\end{tabular}

\begin{tabular}{|c|c|c|c|c|c|c|c|}
\hline Quadrante & Camada & $\begin{array}{c}\mathrm{T}_{\text {pré }} \\
\left({ }^{\circ} \mathrm{C}\right)\end{array}$ & $\begin{array}{c}\mathrm{T}_{\text {interpasse }} \\
\left({ }^{\circ} \mathrm{C}\right)\end{array}$ & $\begin{array}{c}\text { Corrente } \\
(\mathrm{A})\end{array}$ & $\begin{array}{c}\text { Tensão } \\
(\mathrm{V})\end{array}$ & $\begin{array}{c}\text { Velocidade } \\
(\mathrm{cm} / \mathrm{s})\end{array}$ & $\begin{array}{c}\mathrm{E}_{\text {soldagem }} \\
(\mathrm{J} / \mathrm{cm})\end{array}$ \\
\hline \multirow{5}{*}{2} & 1 & 175,0 & 124,3 & 130,0 & 17,6 & 0,75 & 2300,5 \\
\cline { 2 - 8 } & 2 & 167,7 & 233,3 & 145,8 & 23,4 & 0,80 & 3191,7 \\
\cline { 2 - 8 } & 3 & 178,7 & 224,7 & 148,4 & 23,5 & 0,64 & 4094,8 \\
\cline { 2 - 8 } & 4 & 157,7 & 205,7 & 152,4 & 23,5 & 0,91 & 2937,7 \\
\cline { 2 - 8 } & 5 & 166,3 & 183,0 & 154,0 & 23,5 & 0,88 & 3079,9 \\
\cline { 2 - 8 } & 7 & 167,0 & 201,3 & 149,2 & 23,5 & 0,67 & 3946,1 \\
\hline
\end{tabular}

\begin{tabular}{|c|c|c|c|c|c|c|c|}
\hline Quadrante & Camada & $\begin{array}{c}\mathrm{T}_{\text {pré }} \\
\left({ }^{\circ} \mathrm{C}\right)\end{array}$ & $\begin{array}{c}\mathrm{T}_{\text {interpasse }} \\
\left({ }^{\circ} \mathrm{C}\right)\end{array}$ & $\begin{array}{c}\text { Corrente } \\
(\mathrm{A})\end{array}$ & $\begin{array}{c}\text { Tensão } \\
(\mathrm{V})\end{array}$ & $\begin{array}{c}\text { Velocidade } \\
(\mathrm{cm} / \mathrm{s})\end{array}$ & $\begin{array}{c}\mathrm{E}_{\text {soldagem }} \\
(\mathrm{J} / \mathrm{cm})\end{array}$ \\
\hline \multirow{6}{*}{3} & 1 & 199,0 & 202,3 & 122,4 & 18,5 & 1,03 & 1644,2 \\
\cline { 2 - 8 } & 2 & 165,3 & 194,7 & 144,4 & 23,5 & 1,02 & 2494,3 \\
\cline { 2 - 8 } & 3 & 155,7 & 163,0 & 148,0 & 23,5 & 1,09 & 2392,5 \\
\cline { 2 - 8 } & 4 & 181,0 & 215,0 & 150,0 & 23,4 & 0,87 & 3023,3 \\
\cline { 2 - 8 } & 5 & 164,7 & 211,3 & 146,6 & 23,5 & 0,84 & 3055,9 \\
\cline { 2 - 8 } & 6 & 163,7 & 217,3 & 153,0 & 23,5 & 0,89 & 3017,8 \\
\cline { 2 - 8 } & 7 & 160,0 & 181,0 & 150,8 & 23,4 & 0,73 & 3647,3 \\
\hline
\end{tabular}

\begin{tabular}{|c|c|c|c|c|c|c|c|}
\hline Quadrante & Camada & $\begin{array}{c}\mathrm{T}_{\text {pré }} \\
\left({ }^{\circ} \mathrm{C}\right)\end{array}$ & $\begin{array}{c}\mathrm{T}_{\text {interpasse }} \\
\left({ }^{\circ} \mathrm{C}\right)\end{array}$ & $\begin{array}{c}\text { Corrente } \\
(\mathrm{A})\end{array}$ & $\begin{array}{c}\text { Tensão } \\
(\mathrm{V})\end{array}$ & $\begin{array}{c}\text { Velocidade } \\
(\mathrm{cm} / \mathrm{s})\end{array}$ & $\begin{array}{c}\mathrm{E}_{\text {soldagem }} \\
(\mathrm{J} / \mathrm{cm})\end{array}$ \\
\hline \multirow{6}{*}{4} & 1 & 166,7 & 165,3 & 139,8 & 17,5 & 0,74 & 2483,3 \\
\cline { 2 - 8 } & 2 & 168,7 & 228,3 & 145,0 & 23,4 & 1,01 & 2530,7 \\
\cline { 2 - 8 } & 3 & 180,3 & 242,0 & 139,8 & 23,5 & 0,59 & 4136,2 \\
\cline { 2 - 8 } & 4 & 164,3 & 189,0 & 149,0 & 23,5 & 0,84 & 3147,3 \\
\cline { 2 - 8 } & 5 & 167,7 & 174,3 & 147,8 & 23,5 & 0,96 & 2716,5 \\
\cline { 2 - 8 } & 6 & 172,7 & 209,3 & 153,4 & 23,5 & 0,81 & 3338,0 \\
\cline { 2 - 8 } & 7 & 155,7 & 184,0 & 151,0 & 23,4 & 0,82 & 3246,4 \\
\hline
\end{tabular}

Nota: a eficiência de transferência de calor para o processo de soldagem com eletrodo tubular foi admitido como sendo igual a 0,75 . 


\subsubsection{Acompanhamento de soldagem:}

O acompanhamento da soldagem dos anéis foi realizado pelo mestrando, assegurando que o procedimento está sendo cumprido e ainda, registrando e colhendo os dados necessários para a obtenção dos resultados.

\subsubsection{Medida de Temperaturas}

As temperaturas de pré-aquecimento e interpasse foram monitoradas através de termômetro infravermelho com mira laser, modelo MT-350, marca Minipa. O medição da temperatura foi realizada a uma distância de $25 \mathrm{~mm}$ da margem do chanfro e após 1 minuto do afastamento da chama. A figura 33 apresenta os pontos de monitoramento adotados.

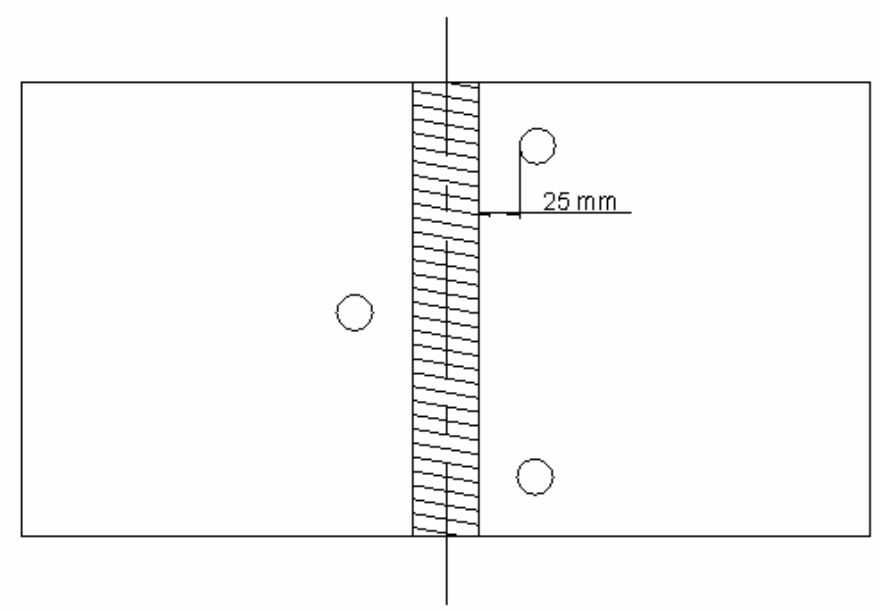

Figura 33- Pontos e distância de monitoramento da temperatura de pré-aquecimento.

\subsubsection{Controle dos parâmetros de soldagem:}

A corrente e tensão de soldagem foram monitoradas através do amperímetro e voltímetro do alimentador de arame no experimento 1. No experimento 2 a corrente e a tensão foram monitoradas através do amperímetro e voltímetro instalados na fonte de soldagem.

$\mathrm{O}$ tempo de soldagem foi obtido através de um cronômetro. A velocidade de soldagem foi calculada dividindo o tempo demandado entre o ponto 1 e 5 pela distância entre os mesmos para cada quadrante. 
A figura 34 apresenta os 5 pontos de coleta de parâmetros adotado por quadrante para ambos os procedimentos.

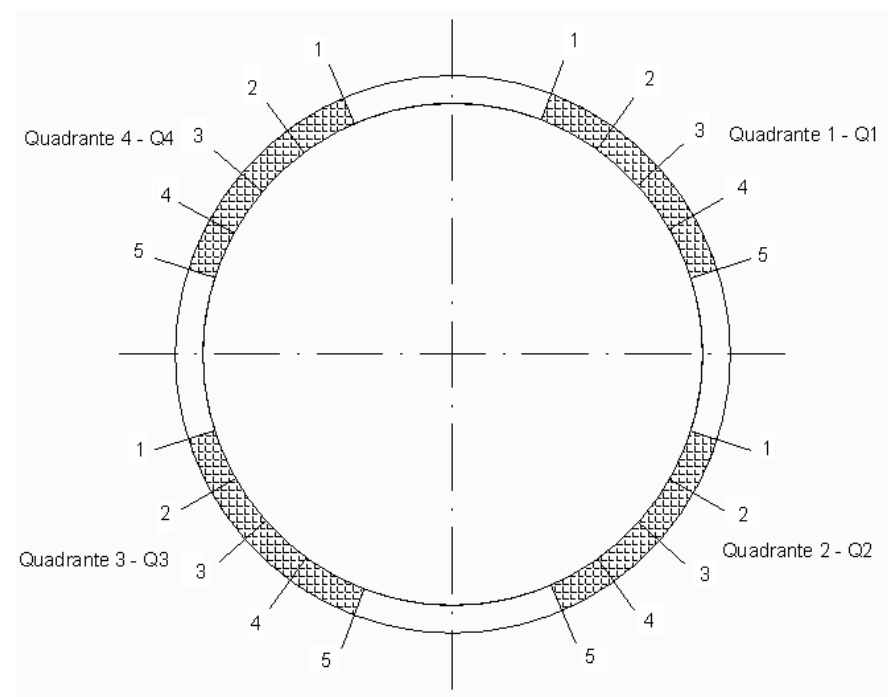

Figura 34- Pontos de coleta de parâmetros por quadrante.

\subsubsection{Ensaios não destrutivos:}

Durante e após a execução da soldagem das juntas foi efetuado o END (Ensaio Não Destrutivo) Visual de Solda (EVS) de modo a garantir a sanidade da junta soldada.

O ensaio visual de solda (EVS) foi executado durante e após $72 \mathrm{~h}$ do término da soldagem de forma a garantir o controle dimensional e a inexistência de defeitos que poderiam comprometer a sanidade da junta soldada.

O critério de aceitação adotado foi conforme o item 6.4 da norma API 1104 [8], onde para a solda ser considerada aprovada, deve satisfazer as seguintes condições:

1. Não existência de trincas, falta de penetração e perfuração;

2. Possuir boa aparência;

3. Se existirem mordeduras, estas devem possuir profundidade máxima de $0,8 \mathrm{~mm}$ ou $12,5 \%$ da espessura do tubo, o que for menor, e não devem somar mais que $50 \mathrm{~mm}$ de comprimento em $300 \mathrm{~mm}$ contínuos de solda. 
4. Se for utilizado processo de soldagem semi-automático ou mecanizado, a protuberância fundida do eletrodo dentro do tubo deve ser mínima.

\subsection{Caracterização metalográfica:}

Após o término da etapa de soldagem foram extraídos corpos de prova de localização adjacente aos quadrantes destinados a ensaios mecânicos para a caracterização metalográfica. A região de extração compreende as posições de soldagem plana, vertical e sobre-cabeça, conforme apresentado na figura 35.

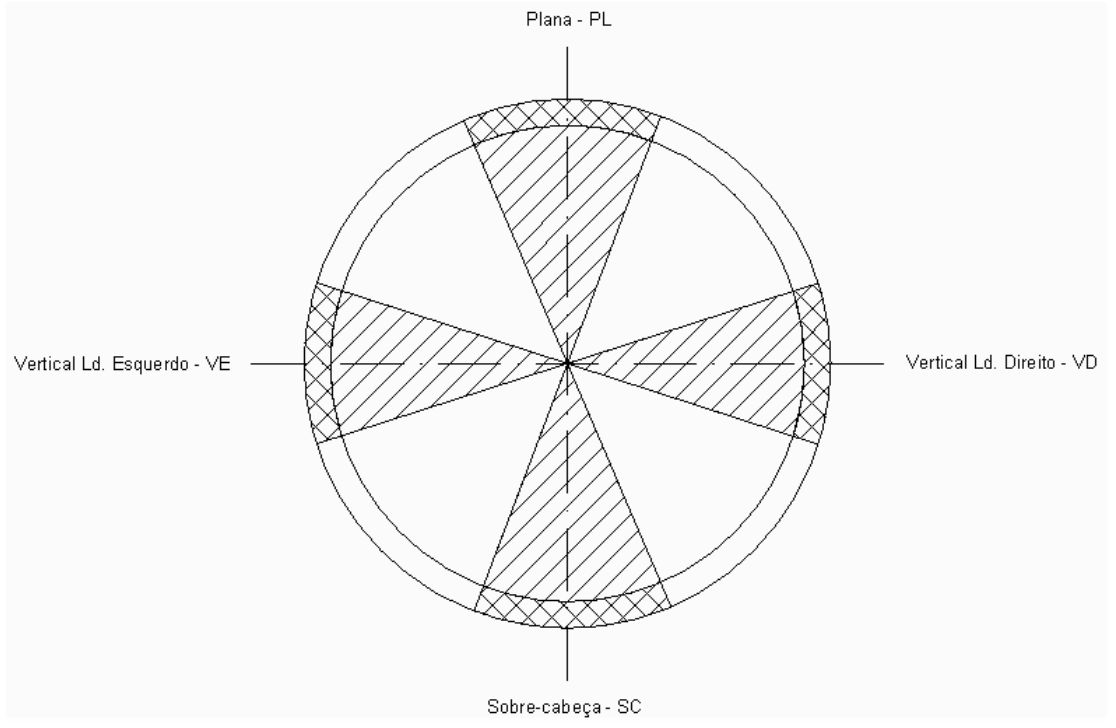

Figura 35- Região de extração dos corpos de prova para os ensaios metalográficos e químicos, representando as posições de soldagem.

Os ensaios de caracterização metalográfica realizados foram:

\subsubsection{Macrografia:}

Foram realizadas macrografias das soldas dos 2 tubos nas 4 regiões que representam as posições de soldagem, conforme figura 35, a fim de verificar o perfil dos cordões e a extensão do ZAC. O reagente utilizado foi Nital $5 \%$.

\subsubsection{Microscopia óptica:}

Foi realizada a observação em microscópio ótico das micrografias dos 2 tubos nas 4 regiões que representam as posições de soldagem, conforme 
figura 35, adjacente as da macrografia, a fim de observar a microestrutura resultante do metal de solda, ZAC e metal base. Os ataques foram realizados com Nital $2 \%$, a fim de revelar os contornos de grão.

\subsubsection{Microscopia eletrônica de varredura - MEV}

Foi realizada a observação da fratura em corpos de prova do ensaio de nick-break de cada tubo e do ensaio Charpy, a fim de verificar a característica da fratura resultante.

\subsubsection{Microanálise por Dispersão de Energia - EDS}

Quando do exame no microscópio eletrônico de varredura, foi realizada a análise da composição química do metal de solda, ZTA, metal base e dos compostos formados durante a soldagem ou anteriormente presentes no metal base.

4.4.5 Determinação do agregado $M A$.

\subsubsection{Metalografia quantitativa:}

A determinação do agregado MA foi realizado empregando-se $o$ ataque Klemm, que colore a microestrutura e deixa o agregado MA sem ataque. Foram medidos seis campos com retículos de $100 \times 100$ pontos. Quando o ponto caia dentro da fase contava-se 1 e no caso do ponto cair na interface contava-se 0,5. O reagente Klemm 1 consiste da adição de $1 \mathrm{~g}$ de metabissulfito de potássio em $50 \mathrm{ml}$ de solução saturada de tiossulfeto de sódio.

\subsubsection{Ensaio de saturação magnética:}

Foi executado o ensaio de saturação magnética em corpos de prova extraídos nas posições plana e vertical (figura 35), das soldas de ambos os 
experimentos, bem como da solda longitudinal e do metal base do tubo, tendo como objetivo detectar a quantidade de MA presente na microestrutura.

A fim de determinar o nível mínimo de MA na microestrutura, as amostras das soldas longitudinal e do metal base foram tratadas a $400^{\circ} \mathrm{C}$ por 1 hora. Segundo Ramírez [26], estes parâmetros são suficientes para praticamente zerar a quantidade de MA presente na microestrutura.

Os corpos de prova para este ensaio foram fresados até a espessura de $5 \mathrm{~mm}$ e em seguida, devido a sua pequena dimensão, foram extraídos pelo processo de eletro-erosão a fio.

A figura 36 apresenta as regiões de extração dos corpos de prova para o ensaio de saturação magnética e a figura 37 apresenta as dimensões dos corpos de prova.

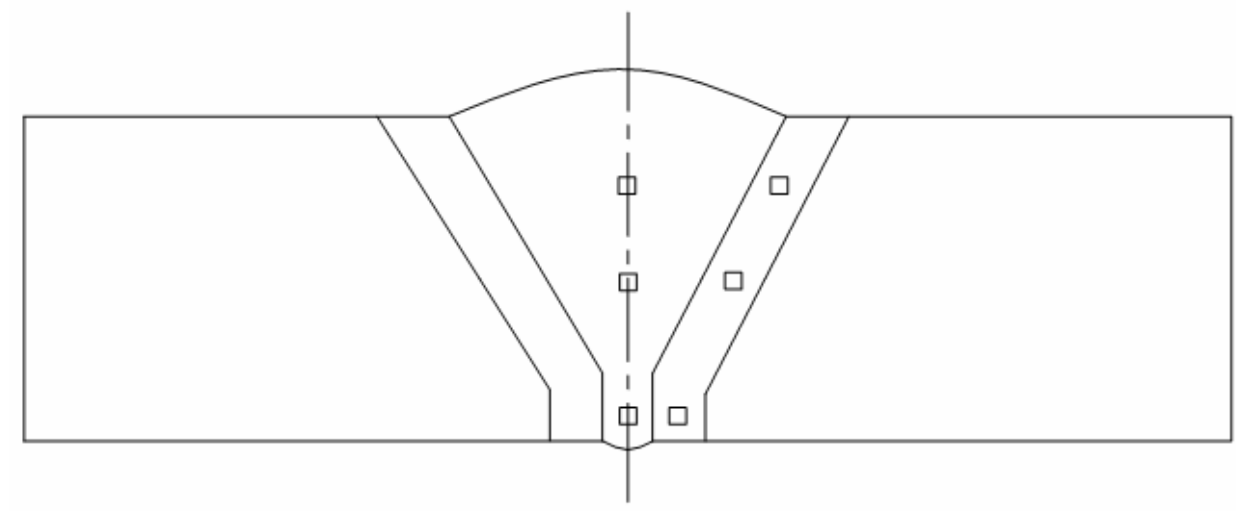

Figura 36- Regiões de extração dos corpos de prova para o ensaio de saturação magnética.
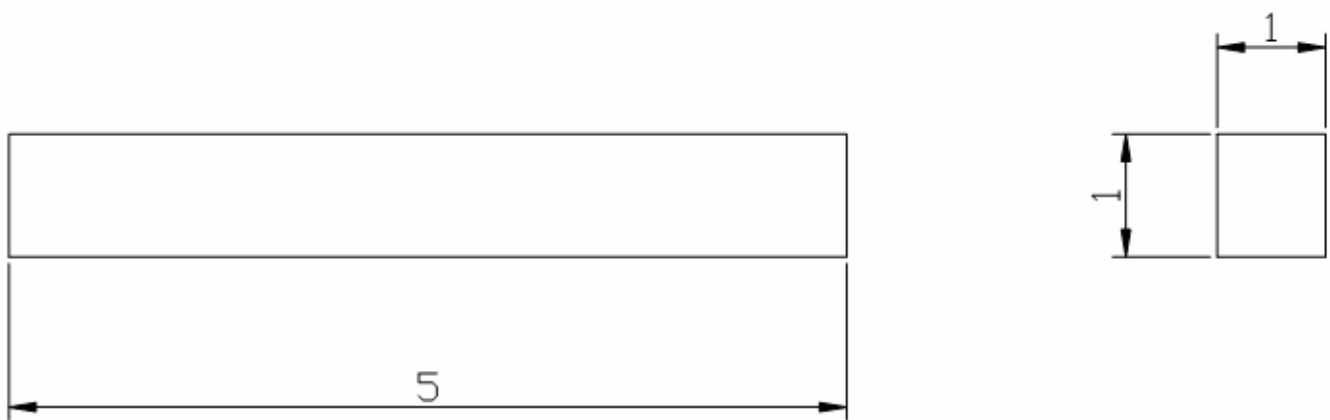

Figura 37- Dimensão dos corpos de prova para o ensaio de saturação magnética. OBS: Dimensões em mm 


\subsection{Determinação da composição química:}

Foi realizada a determinação da composição química em ambos os tubos, através de espectrometria ótica nos corpos de prova extraídos conforme as posições de soldagem (figura 35). A figura 38 apresenta os pontos de ensaio dos corpos de prova.

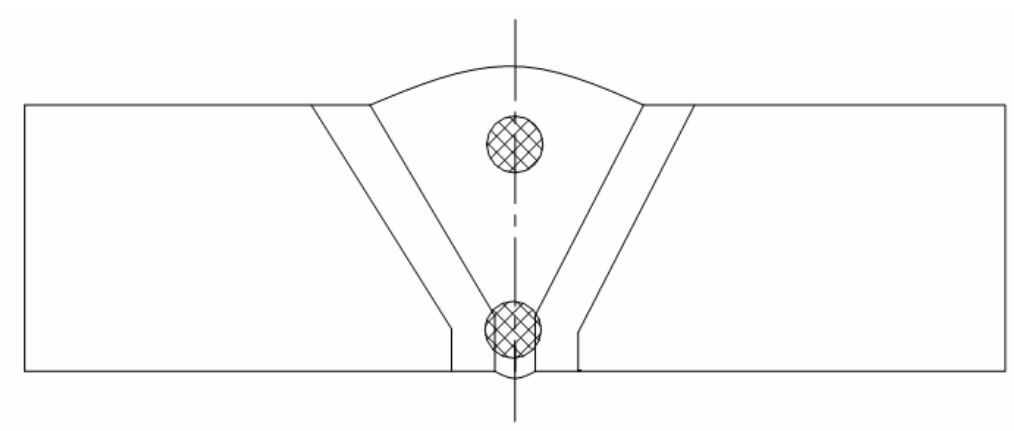

Figura 38- Pontos de ensaio de espectrometria para determinação da composição química.

\subsubsection{Determinação do teor de oxigênio e nitrogênio:}

Foi executada a determinação do teor de oxigênio e nitrogênio através de cromatografia gasosa (LECO), a fim de verificar o teor dos mesmos no metal de solda. $\mathrm{O}$ ensaio foi executado na solda do quadrante 04 de ambos os tubos.

\subsection{Ensaios mecânicos:}

Além dos ensaios requeridos para a qualificação de um procedimento de soldagem conforme a norma API 1104 [8] foi executado o levantamento do perfil de dureza da junta soldada, conforme recomendado pela norma $\mathrm{N}-133$ [77] e o ensaio de impacto Charpy- $V$ para a avaliação da energia absorvida, tendo como base os requisitos da norma API 5L. Na solda longitudinal do tubo foram executados os mesmos ensaios mecânicos realizados na solda dos experimentos, a exceção do ensaio de dobramento lateral e nick-break. $O$ ensaio de tração da solda longitudinal do tubo foi executado segundo a especificação API 5L [9], pois esta solda está relacionada ao processo produtivo do tubo. 


\subsubsection{Perfil de dureza:}

Foi realizado o levantamento do perfil de dureza tanto da solda dos experimentos quanto da solda longitudinal do tubo, a fim de verificar a variação desta entre as diferentes regiões da junta soldada. Os corpos de prova foram extraídos das regiões apresentadas na figura 35 . Os pontos de medição de dureza foram executados conforme sugestão da norma $\mathrm{N}-133$ [77], acrescidos de no mínimo 3 pontos de medição por região e uma linha de perfil adicional na metade da junta. A figura 39 apresenta os pontos utilizados.

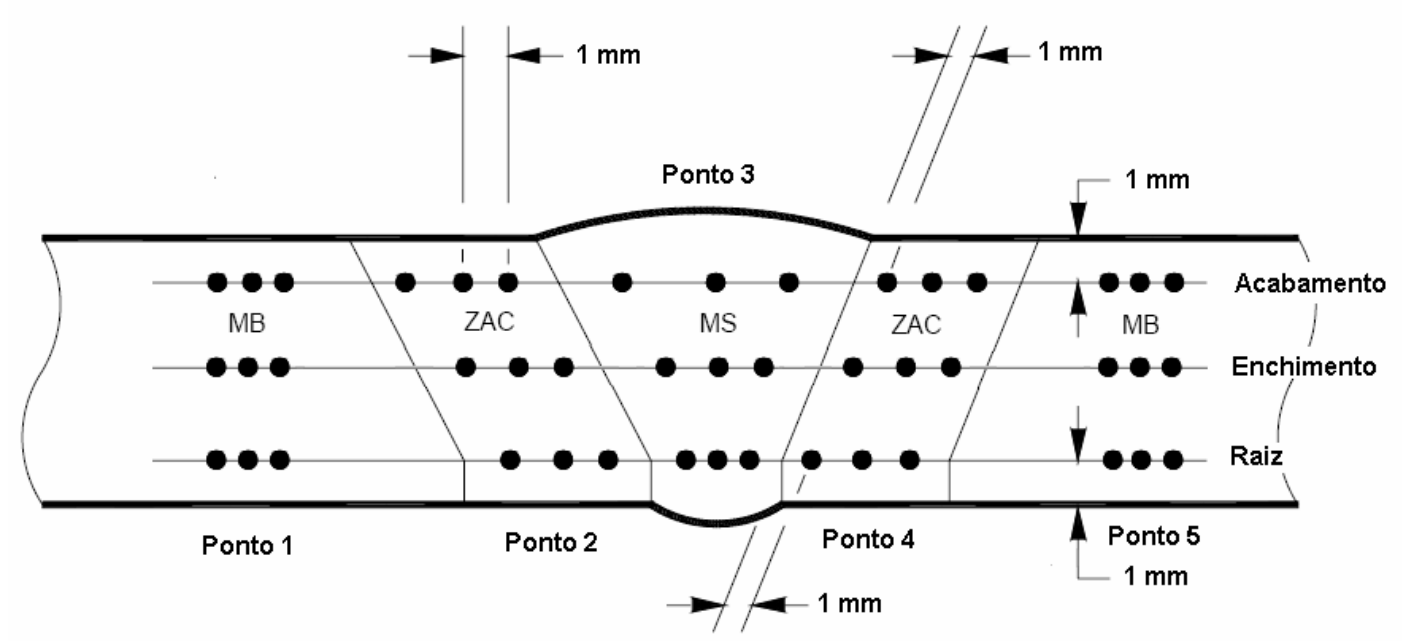

Figura 39- Pontos utilizados para medição de dureza. Baseado na ref. [77].

\subsubsection{Ensaio de tração:}

Os corpos de prova de tração da junta soldada dos anéis foram extraídos das regiões indicadas na Figura 31, totalizando 4 corpos de prova por anel. As dimensões finais, conforme a norma API 1104, são apresentadas na Figura 40.

A norma API 5L [9] determina que o ensaio de tração do material do tubo seja realizado tanto no sentido longitudinal quanto no sentido transversal. O ensaio de tração da solda longitudinal do tubo é realizado somente no sentido transversal. Foram extraídos 4 corpos de prova para cada ensaio.

Os corpos de prova foram extraídos das regiões recomendadas pela norma API 5L [9]. As figuras 41 e 42 apresentam a região de extração dos corpos de prova e suas dimensões. 


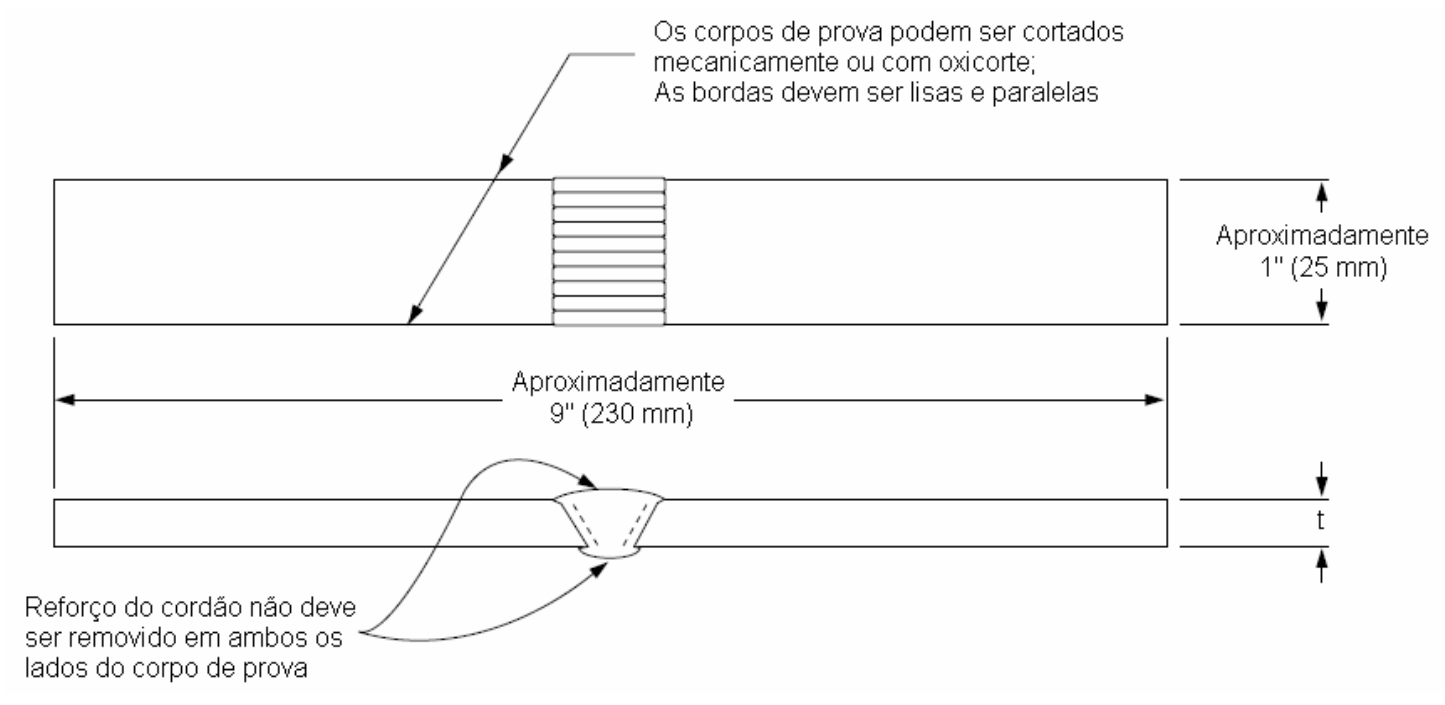

Figura 40- Dimensões dos corpos de prova do ensaio de tração, conforme API 1104 [9].

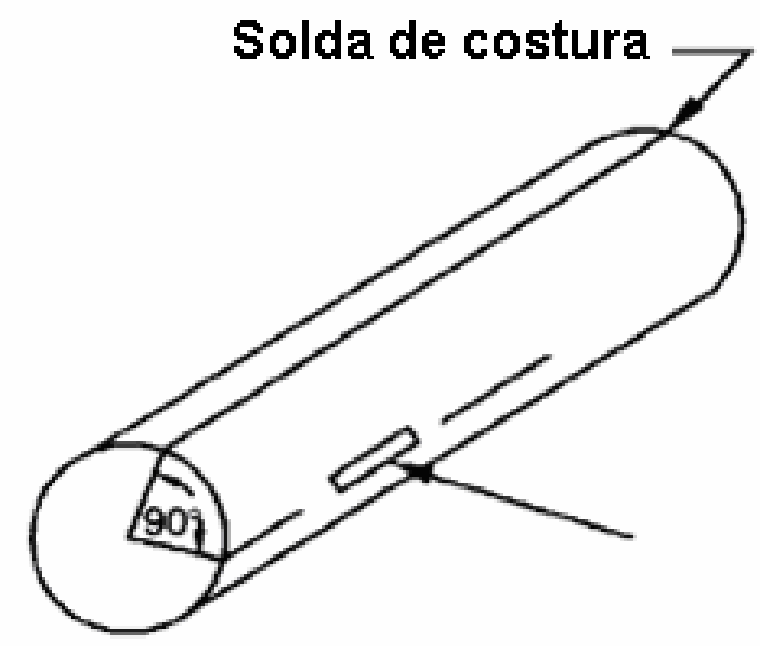

(a) Região de extração dos corpos de prova no sentido longitudinal.

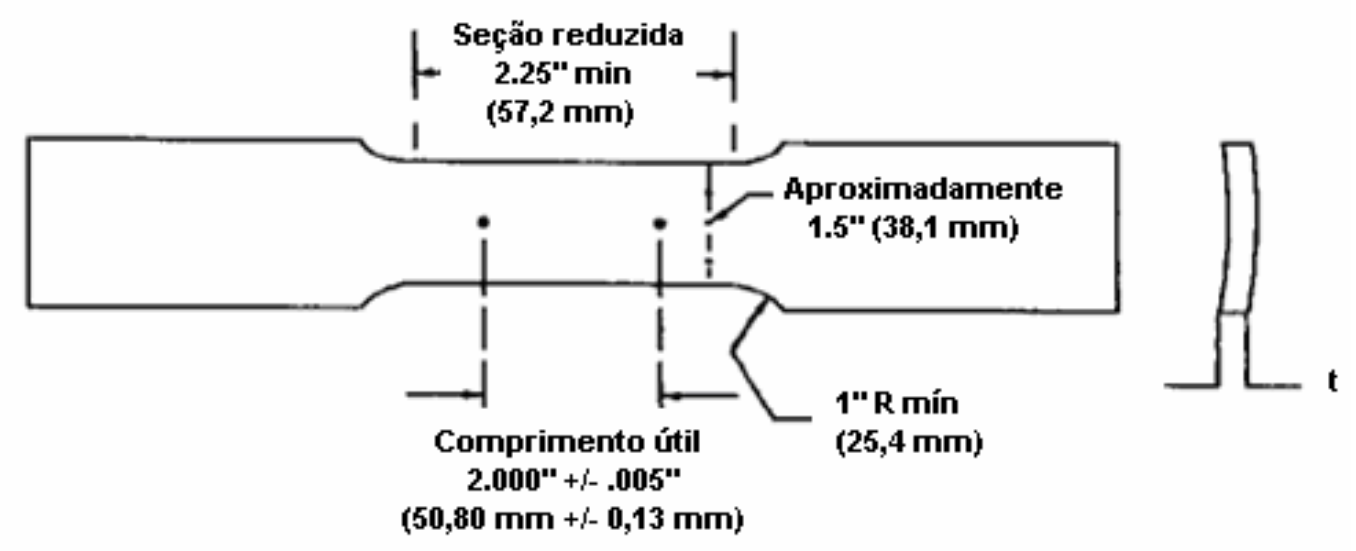

(b) Dimensões dos corpos de prova - sentido longitudinal.

Figura 41- Região de extração e dimensão dos corpos de prova no sentido longitudinal [9]. 


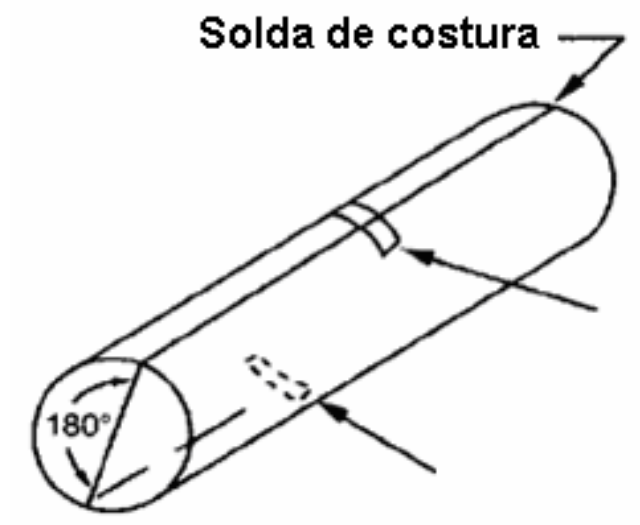

(a) Região de extração dos corpos de prova no sentido transversal.

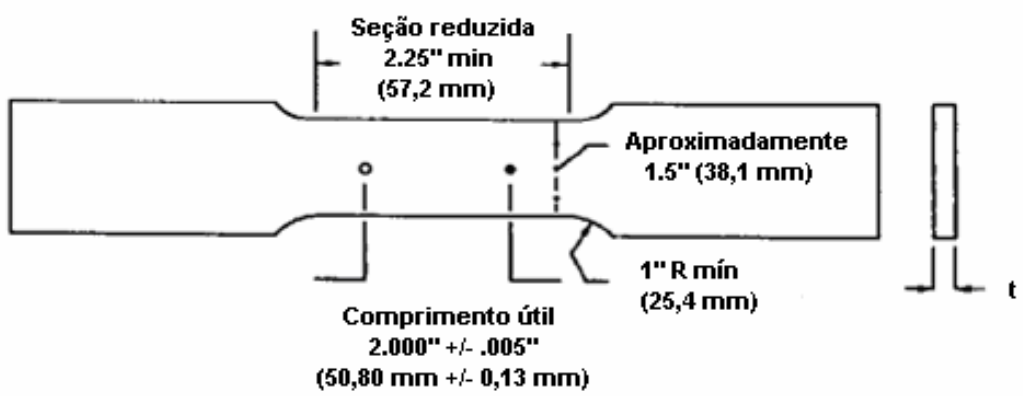

Corpo de prova - Metal base

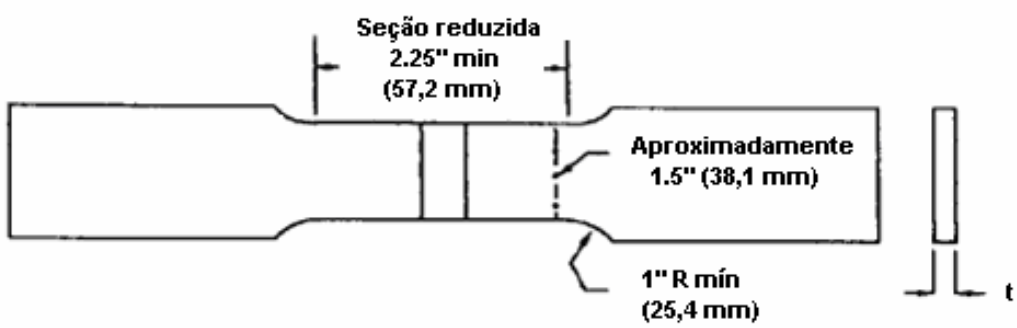

Corpo de prova - Metal de solda

(b) Dimensões dos corpos de prova - sentido transversal.

Figura 42- Região de extração e dimensões dos corpos de prova - sentido transversal [9].

Os corpos de prova extraídos no sentido transversal devem ser "achatados" com o auxílio de uma prensa antes do ensaio [9]. Os cantos de todos os corpos de prova serão chanfrados a fim de evitar pontos de concentrações de tensões [8]. 
Para serem considerados aprovados os corpos de prova devem possuir o limite de resistência e de escoamento dentro da faixa de 90 a 120 ksi e 80 a 100 ksi, respectivamente, não podendo a razão elástica LE/LR ultrapassar 0,93 .

4.6.3 Ensaio de dobramento:

Os corpos de prova para o ensaio de dobramento foram extraídos das regiões indicadas na figura 31, totalizando 8 corpos de prova por anel. As dimensões, conforme a norma API 1104 [8] são apresentadas na figura 43.

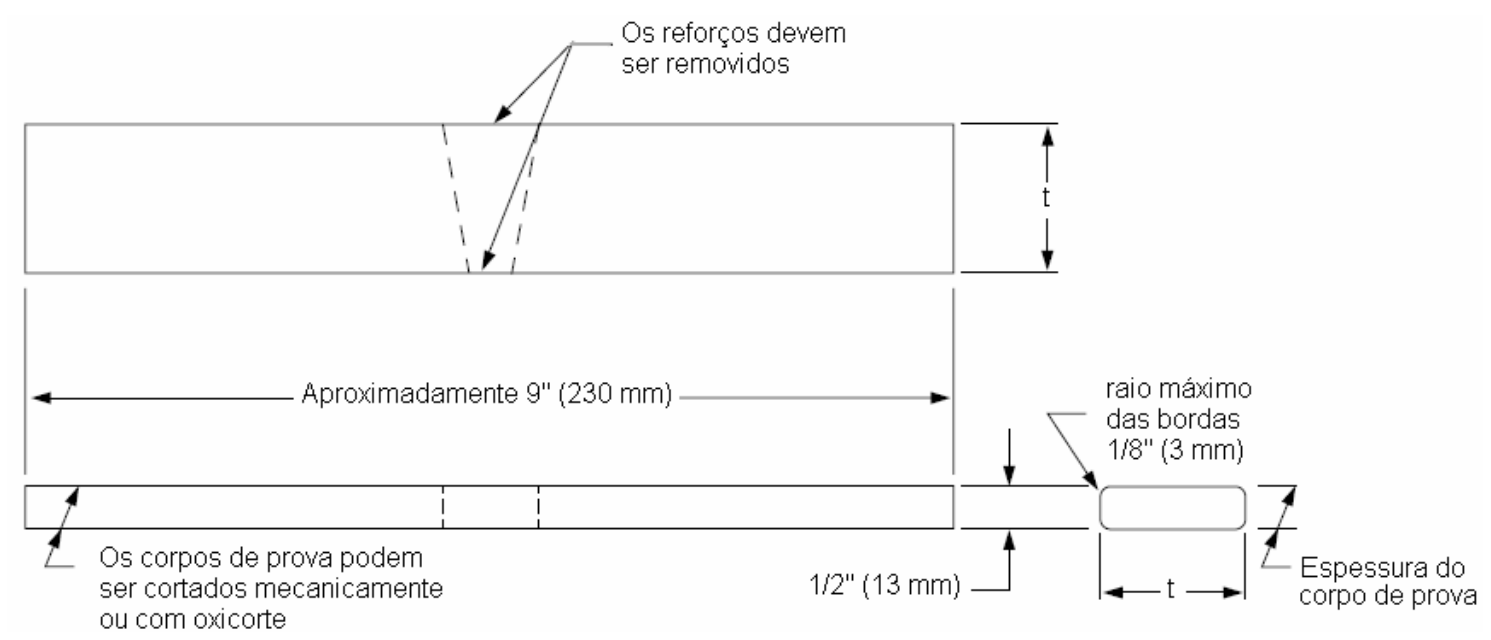

Figura 43- Dimensões dos corpos de prova do ensaio de dobramento lateral, conforme API 1104 [8].

\subsubsection{Ensaio nick-break:}

Os corpos de prova para o ensaio nick-break também foram extraídos das regiões indicadas na figura 31 , totalizando 4 corpos de prova por anel. As dimensões dos corpos de prova são apresentadas na figura 45. A API 1104 [8] recomenda que os corpos de prova para o ensaio nick-break soldados com processos mecanizados ou semi-automáticos possuam um entalhe adicional no cordão de solda, conforme figura 44. 


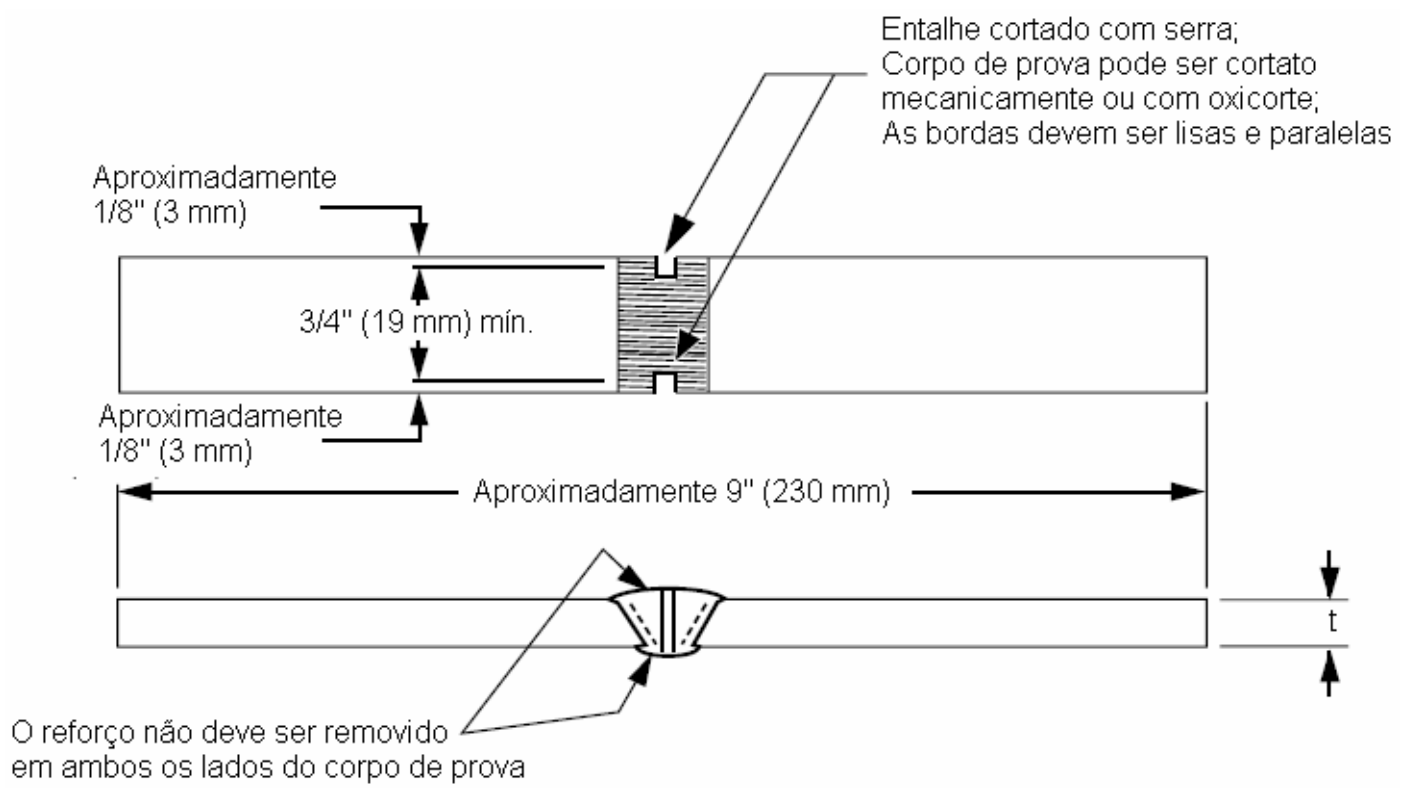

(a) Dimensões dos corpos de prova do ensaio nick-break.

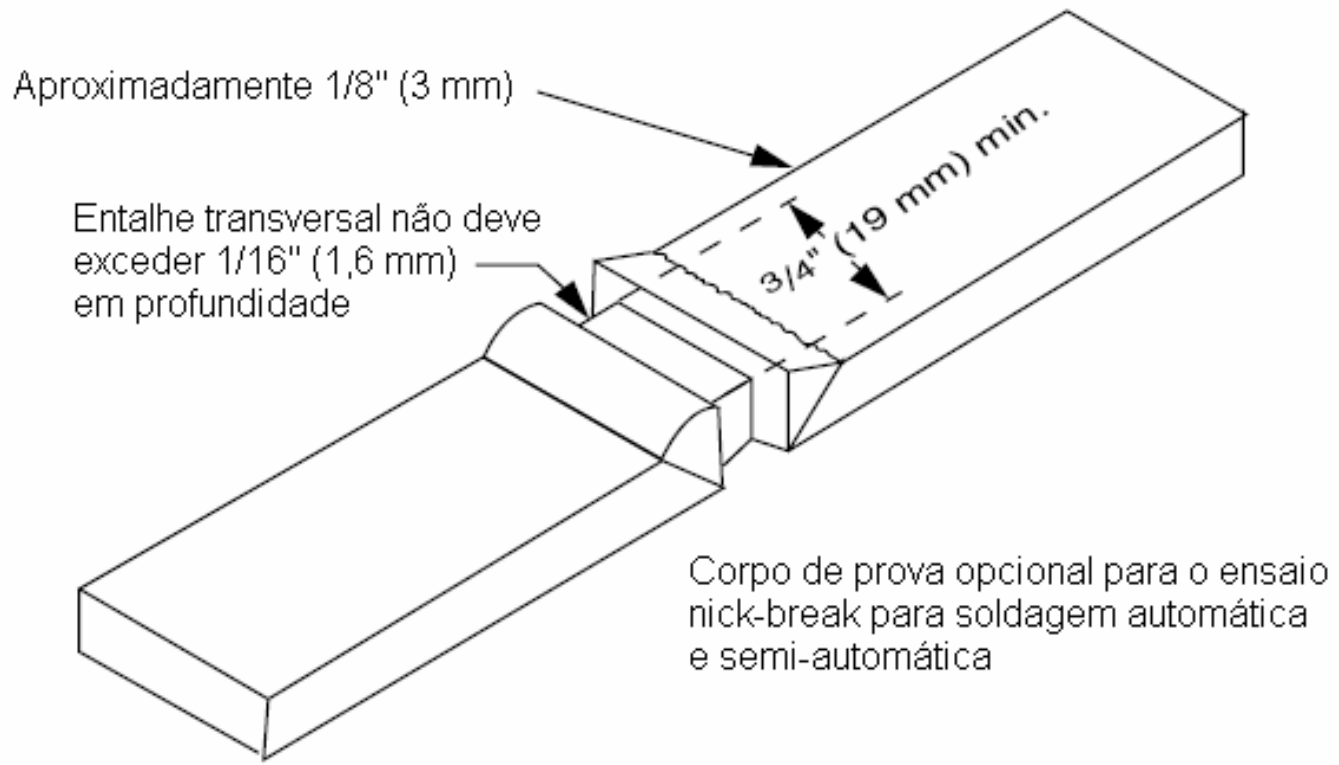

(b) Entalhe adicional recomendado pela API 1104 para corpos de prova soldados com processos mecanizados ou semi-automáticos.

Figura 44- Dimensões dos corpos de prova do ensaio de Nick-break e entalhe adicional recomendado pela API 1104 para corpos de prova soldados com processos mecanizados ou semi-automáticos, conforme API 1104 [8]. 


\subsubsection{Ensaio de impacto:}

O ensaio de impacto (Charpy- $V$ ) foi executado no metal base, na solda longitudinal do tubo, metal de solda (raiz e enchimento) e ZAC, nas soldas dos 4 quadrantes dos tubos $1 \mathrm{~A}$ e $2 \mathrm{~A}$, sendo extraídos das regiões apresentadas na figura 32. O objetivo foi comparar a energia absorvida entre as soldas dos experimentos e longitudinal nem relação ao metal base. A temperatura de ensaio adotada foi $0{ }^{\circ} \mathrm{C}$. Para ser considerado aprovado a energia absorvida por todas as soldas deve ser maior ou igual a 101J, conforme requerido na norma API 5L [9].

Também foi realizado ensaio de impacto no corpos de prova da solda longitudinal e metal de base tratados termicamente, a fim verificar a influência do tratamento na energia absorvida.

Os corpos de prova extraídos tanto da solda longitudinal, quanto da solda dos anéis, foram preparados de acordo com a norma ASTM E370 [78].

A figura 45 apresenta as regiões de extração dos corpos de prova para o ensaio de impacto e a figura 46 apresenta as dimensões dos corpos de prova, conforme a norma ASTM E370 [78].
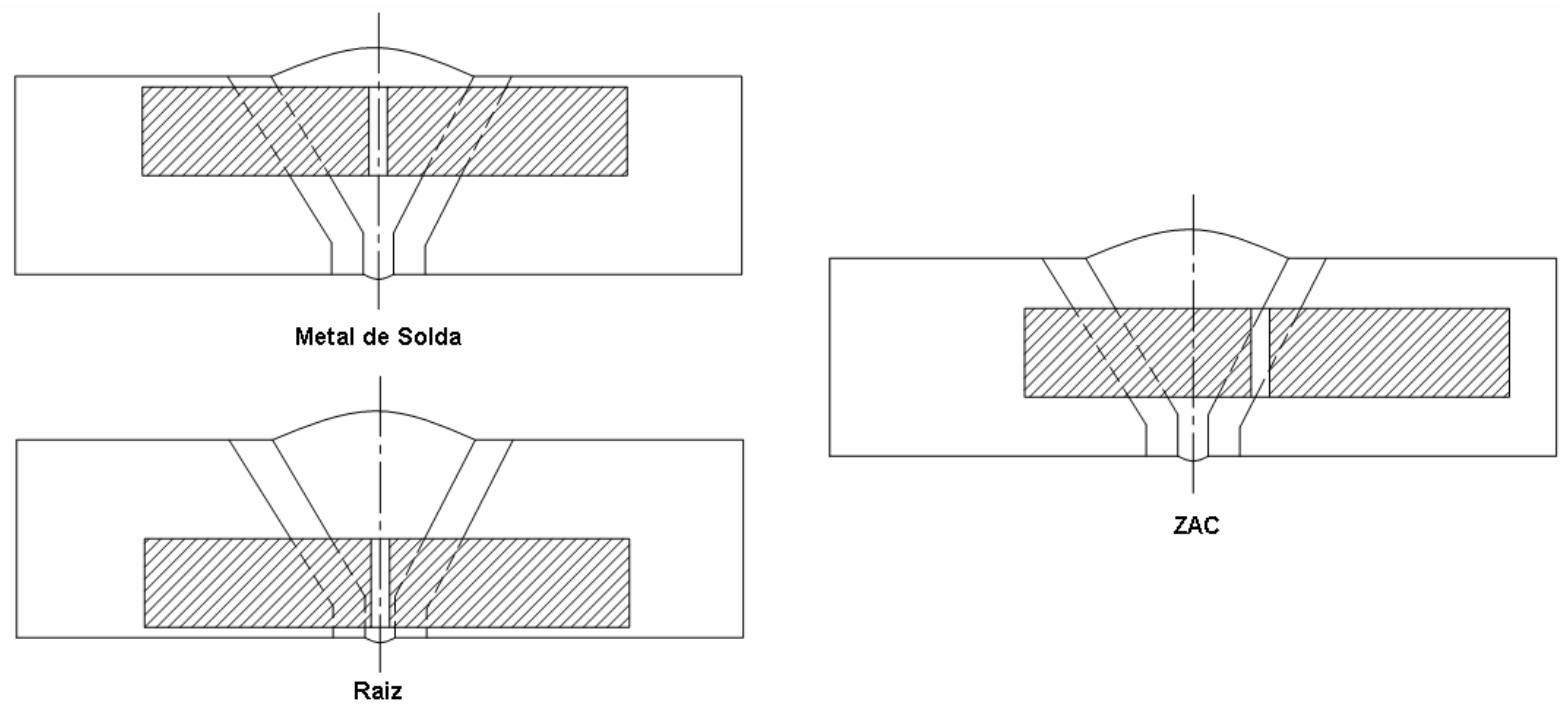

Figura 45- Regiões de extração dos corpos de prova do ensaio de impacto Charpy-V. 

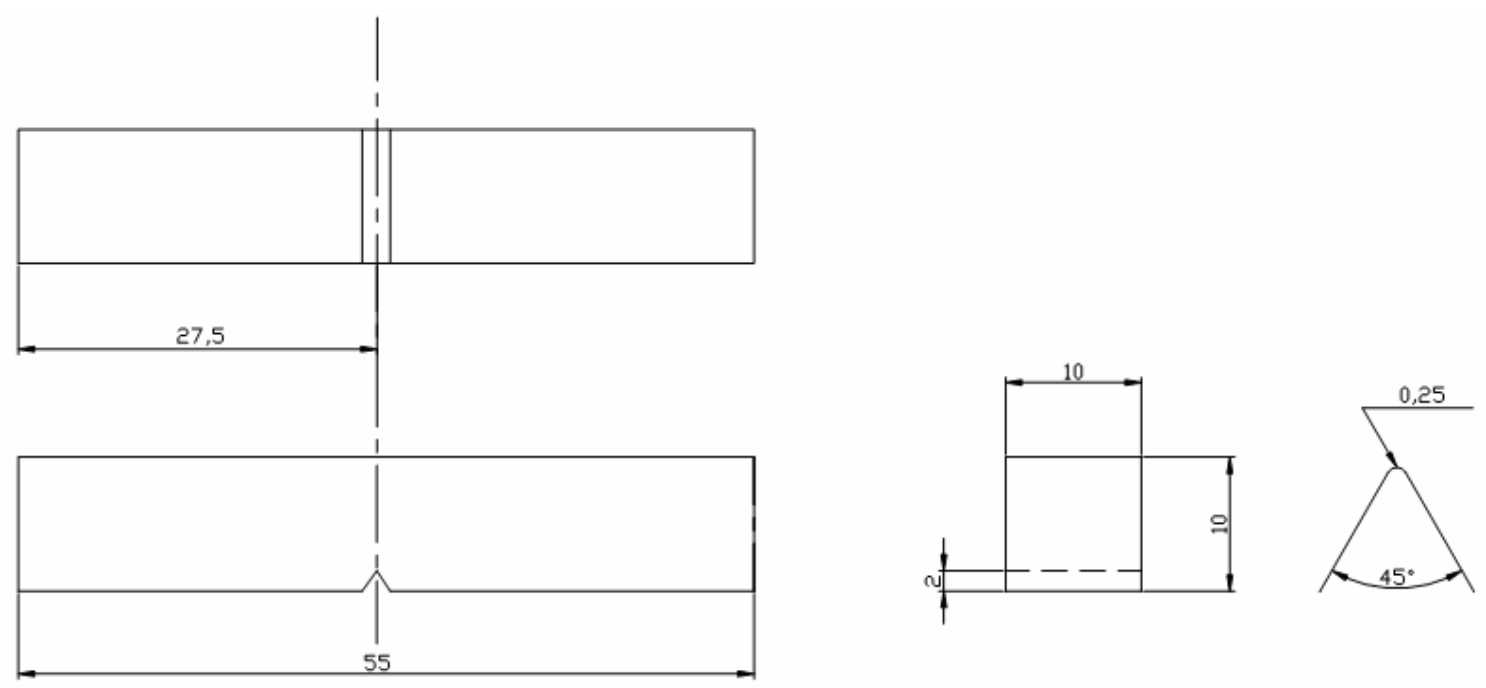

Figura 46- Dimensões dos corpos de prova do ensaio de impacto Charpy-V, conforme ASTM A370 [78]. OBS: Dimensões em mm.

A figura 47 apresenta a região de extração dos corpos de prova do ensaio de impacto no metal base do tubo, conforme API 5L [9].

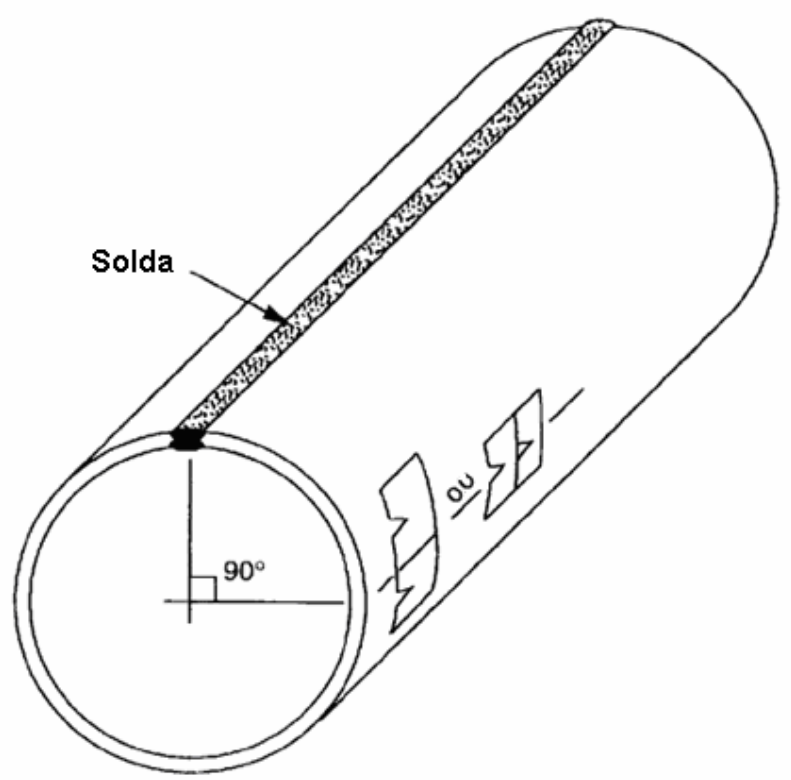

Figura 47- Regiões de extração dos corpos de prova do ensaio de impacto Charpy-V no metal de base do tubo, conforme API 5L [9]. 


\section{RESULTADOS E DISCUSSÃO:}

\subsection{Análise química:}

A tabela 25 apresenta a composição química média obtida para os passes de raiz, enchimento e acabamento e as figuras 48 e 49 apresentam graficamente a composição química dos elementos presentes em maior e menor quantidade, de acordo com os dados da tabela 25.

Tabela 25: Composição química do metal de solda dos passes de raiz, enchimento e acabamento do tubo 1 e 2.

\begin{tabular}{|c|c|c|c|c|}
\hline & Tubo1 - Raiz & Tubo1 - Enchimento & Tubo2 - Raiz & Tubo2 - Enchimento \\
\hline Consumível & ER80S-G & E91T8-G & ER80S-G & E101T1-GM H8 \\
\hline $\mathrm{C}$ & 0,0638 & 0,0378 & 0,0755 & 0,0489 \\
\hline $\mathrm{Si}$ & 0,28 & 0,25 & 0,34 & 0,29 \\
\hline$S$ & 0,0023 & 0,0007 & 0,0064 & 0,0049 \\
\hline$P$ & 0,0115 & 0,0083 & 0,0133 & 0,0134 \\
\hline $\mathrm{Mn}$ & 1,87 & 2,36 & 1,54 & 1,60 \\
\hline $\mathrm{Ni}$ & 0,41 & 0,81 & 0,40 & 0,74 \\
\hline $\mathrm{Cr}$ & 0,049 & 0,033 & 0,045 & 0,056 \\
\hline Mo & 0,20 & 0,050 & 0,32 & 0,25 \\
\hline V & 0,0155 & 0,0121 & 0,0230 & 0,0334 \\
\hline $\mathrm{Cu}$ & 0,069 & 0,021 & 0,093 & 0,024 \\
\hline W & 0,0001 & - & 0,0042 & 0,005 \\
\hline $\mathrm{Ti}$ & 0,0043 & 0,0041 & 0,0219 & 0,0273 \\
\hline Sn & 0,0022 & 0,0026 & 0,0025 & 0,0029 \\
\hline $\mathrm{Al}$ & 0,49 & 0,87 & 0,0079 & 0,011 \\
\hline $\mathrm{Nb}$ & 0,0227 & 0,021 & 0,0148 & 0,0239 \\
\hline $\mathrm{O}(\mathrm{ppm})$ & 381 & 252 & 621 & 658 \\
\hline $\mathrm{N}(\mathrm{ppm})$ & 149 & 368 & 41,5 & 32 \\
\hline CE & 0,461 & 0,505 & 0,442 & 0,434 \\
\hline $\mathrm{Pcm}$ & 0,194 & 0,185 & 0,201 & 0,175 \\
\hline
\end{tabular}




\section{Elementos de liga em maior quantidade}

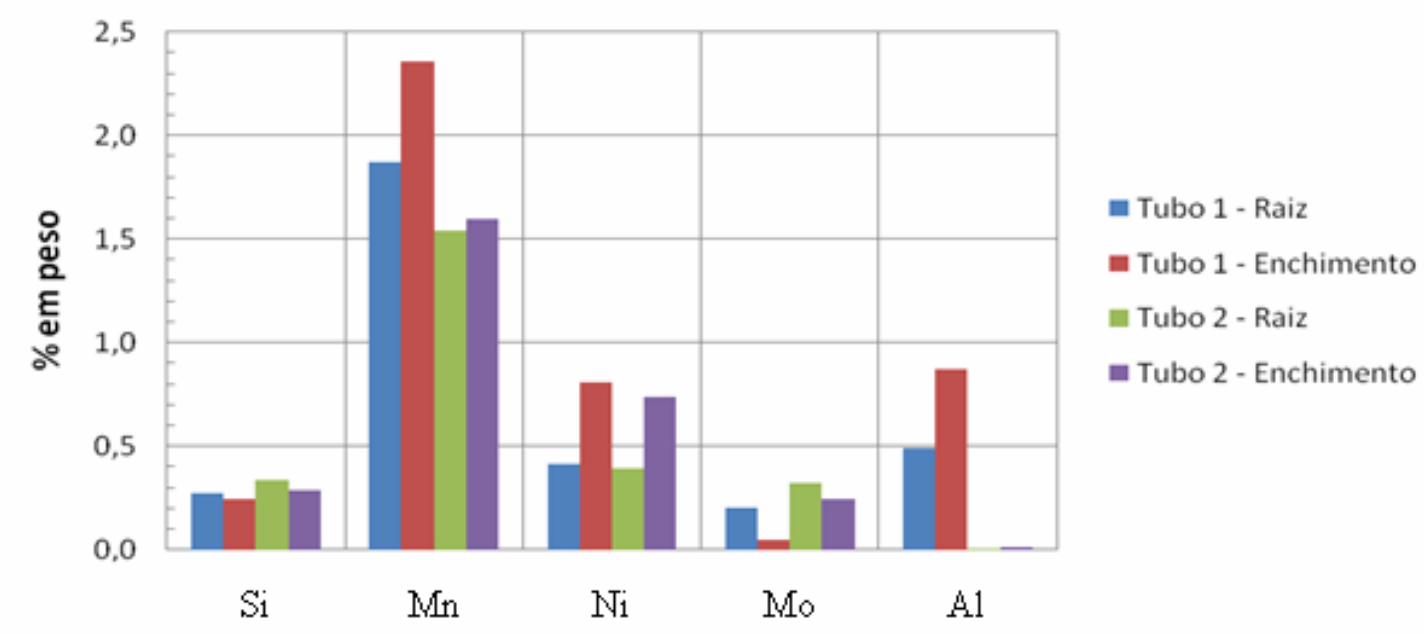

Figura 48: Elementos de liga em maior quantidade, segundo tabela 25.

\section{Elementos de liga em menor quantidade}

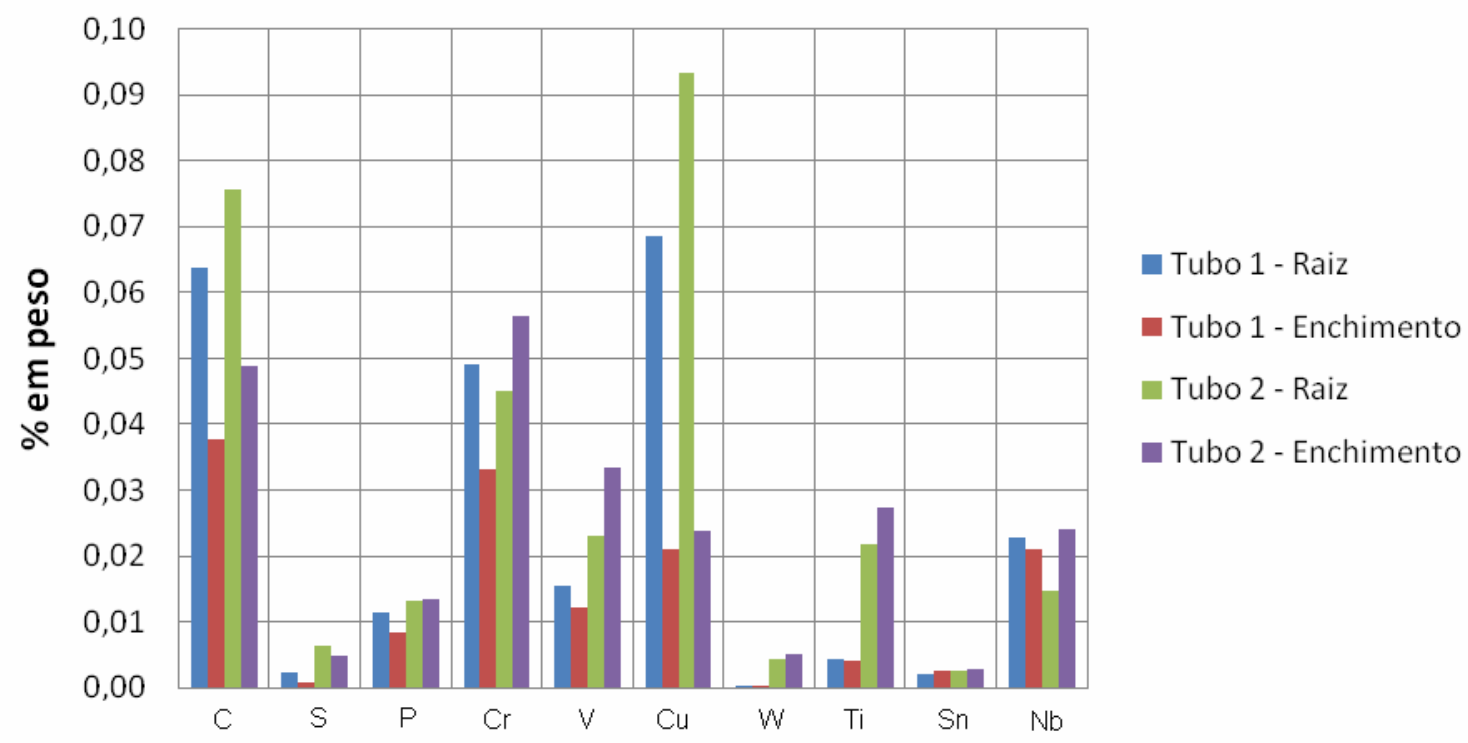

Figura 49: Elementos de liga em maior quantidade, segundo tabela 25.

A partir dos dados da tabela 24 e da figura 48, pode-se observar que o teor de Si foi uniforme para ambos os tubos em todos os passes, sendo um pouco maior nos passes de raiz de ambos os tubos, o que é compatível com o teor de Si apresentado pelo certificado do consumível.

Já em relação ao Mn, pode-se notar que o enchimento do tubo 1 possui o maior teor de $\mathrm{Mn}$ em relação tanto aos passes de raiz de ambos os tubos, quanto ao passe de enchimento do tubo 2. Nota-se também que o teor deste elemento no passe de raiz do tubo 1 foi maior do que o do passe de raiz do 
tubo 2, que utilizou o mesmo consumível. Uma explicação para esta variação é que houve enriquecimento de $\mathrm{Mn}$ no passe de raiz devido a diluição quando da soldagem do enchimento $(2,31 \% \mathrm{Mn})$. Para o tubo 2 percebe-se que o teor de Mn do passe de raiz e do enchimento é muito próximo, o que é confirmado pela análise dos certificados dos consumíveis.

Em relação ao teor de $\mathrm{Ni}$, observa-se que foi maior nos passes de enchimento de ambos os tubos, quando comparados com os passes de raiz, sendo o enchimento do tubo 2 um pouco menor do que o do tubo 1. Pela análise do certificado de ambos os consumíveis o teor de $\mathrm{Ni}$ era o esperado, isto é, o teor de Ni do tubo 1 um pouco mais elevado do que o tubo 2 .

O teor de Mo encontrado no enchimento do tubo 1 foi notadamente menor em relação aos outros passes, tanto de enchimento quanto de acabamento, o que condiz com o certificado do consumível. Pode-se observar que o passe de raiz do tubo 2 apresentou maior teor do que o do tubo 1 , possivelmente devido ao enriquecimento causado pelo maior teor de Mo do enchimento do tubo 2 .

Para o elemento $\mathrm{Al}$, nota-se que está presente tanto no enchimento quanto na raiz do tubo 1 , e que foi praticamente nulo tanto no passe de raiz quanto no enchimento do tubo 2 , o que condiz com os certificados dos consumíveis. Como o consumível utilizado no passe de raiz não apresenta $\mathrm{Al}$ na sua composição, entende-se que o passe de raiz foi enriquecido com o $\mathrm{Al}$ presente nos passes de enchimento do tubo 1.

Pela análise da figura 49, é possível observar que o teor de carbono, determinado através de espectrometria óptica (menor precisão), dos passes de raiz de ambos os tubos foram maiores em relação aos passes de enchimento, notando-se que o houve a tendência de ser maior no tubo 2 , tanto nos passes de raiz e enchimento. Este teor mais elevado no passe de raiz é conseqüência do maior teor de $\mathrm{C}$ presente no consumível utilizado, conforme análise do certificado. Em relação ao aumento observado no tubo 2, este pode estar relacionado com o gás de proteção utilizado pelo consumível do passe de enchimento.

$\mathrm{O}$ teor de $\mathrm{S}$ encontrado no enchimento do tubo 1 foi menor do que $\mathrm{O}$ encontrado no do tubo 2 , sendo que o passe de raiz acompanhou a mesma tendência, o que condiz com o certificado do consumível. Já, em relação ao $P$, 
o enchimento do tubo 1 apresentou o menor teor, em comparação aos passes de enchimento e acabamento, tanto do tubo 1, quanto do tubo 2.

Em relação ao teor de $\mathrm{Cr}$, observa-se que o maior teor foi encontrado no enchimento do tubo 2, em relação aos demais passes. Nota-se também que o teor nos passes de raiz tenderam a ser próximos. Pela análise dos certificados dos consumíveis utilizados no enchimento do tubo 2 , observa-se que o teor de $\mathrm{Cr}$ é próximo, não justificando um aumento substancial no teor deste em relação ao enchimento do tubo 1 .

Para o elemento $\mathrm{V}$, nos passes de raiz houve variação entre os tubos, sendo maior no tubo 2. Esta variação é justificada pelo maior teor de $V$ presente no enchimento do tubo 2, conforme o certificado do consumível.

O teor de $\mathrm{Cu}$ encontrado nos passes de raiz foi notadamente maior do que nos passes de enchimento, embora com grande variação entre os mesmos. Este maior teor foi confirmado pelo certificado do consumível e devese pelo revestimento externo de cobre utilizado nos eletrodos sólidos, a fim de evitar oxidação.

Em relação ao $\mathrm{W}$, o teor nos passes de raiz e enchimento do tubo 1 foi praticamente nulo, enquanto que esteve presente tanto na raiz quanto no enchimento do tubo 2. O certificado dos consumíveis do passe de raiz e do enchimento do tubo 2 não mencionam a presença de $\mathrm{W}$.

O teor de Ti encontrado variou entre o tubo 1 e tubo 2. No caso do tubo 1 permaneceu praticamente uniforme nos passes de raiz e enchimento. Já no tubo 2, o teor de níquel encontrado deve-se ao consumível utilizado no enchimento, tendo o passe de raiz enriquecido em neste elemento através da diluição do passe de enchimento.

Para o Sn, o teor encontrado em todos os passes de ambos os tubos tendeu a apresentar-se praticamente igual, com ligeiro acréscimo no tubo 2. Já para $\circ \mathrm{Nb}$, o menor teor encontrado foi no passe de raiz do tubo 2 , e praticamente igual nos outros passes.

O teor de oxigênio presente na raiz do tubo 1 é de 381 ppm e de 252 ppm no enchimento. A raiz do tubo 2 apresentou teor de oxigênio de 621 ppm, enquanto que no enchimento o teor é de 658 ppm.

Já para o nitrogênio, o teor encontrado na raiz do tubo 1 é de 149 ppm e no enchimento é de 41,5 ppm. A quantidade de nitrogênio encontrada na raiz 
do tubo 2 foi de 621 ppm, enquanto que no enchimento o valor encontrado foi de 32 ppm.

Nota-se que o tubo 2 apresenta uma maior quantidade de oxigênio que o tubo 1. Em relação ao teor de nitrogênio, o tubo 1 apresenta os maiores teores, em comparação ao tubo 2. Esta diferença pode estar relacionada aos tipos de matérias primas para geração de escória/gás de proteção utilizadas em cada eletrodo tubular e a composição química dos metais de solda.

\subsubsection{Variação da composição química:}

As figuras 50 e 51 apresentam a variação da composição química do metal de solda, tanto da raiz quanto do enchimento, em relação à composição química do metal de base e do certificado do consumível para o tubo 1.

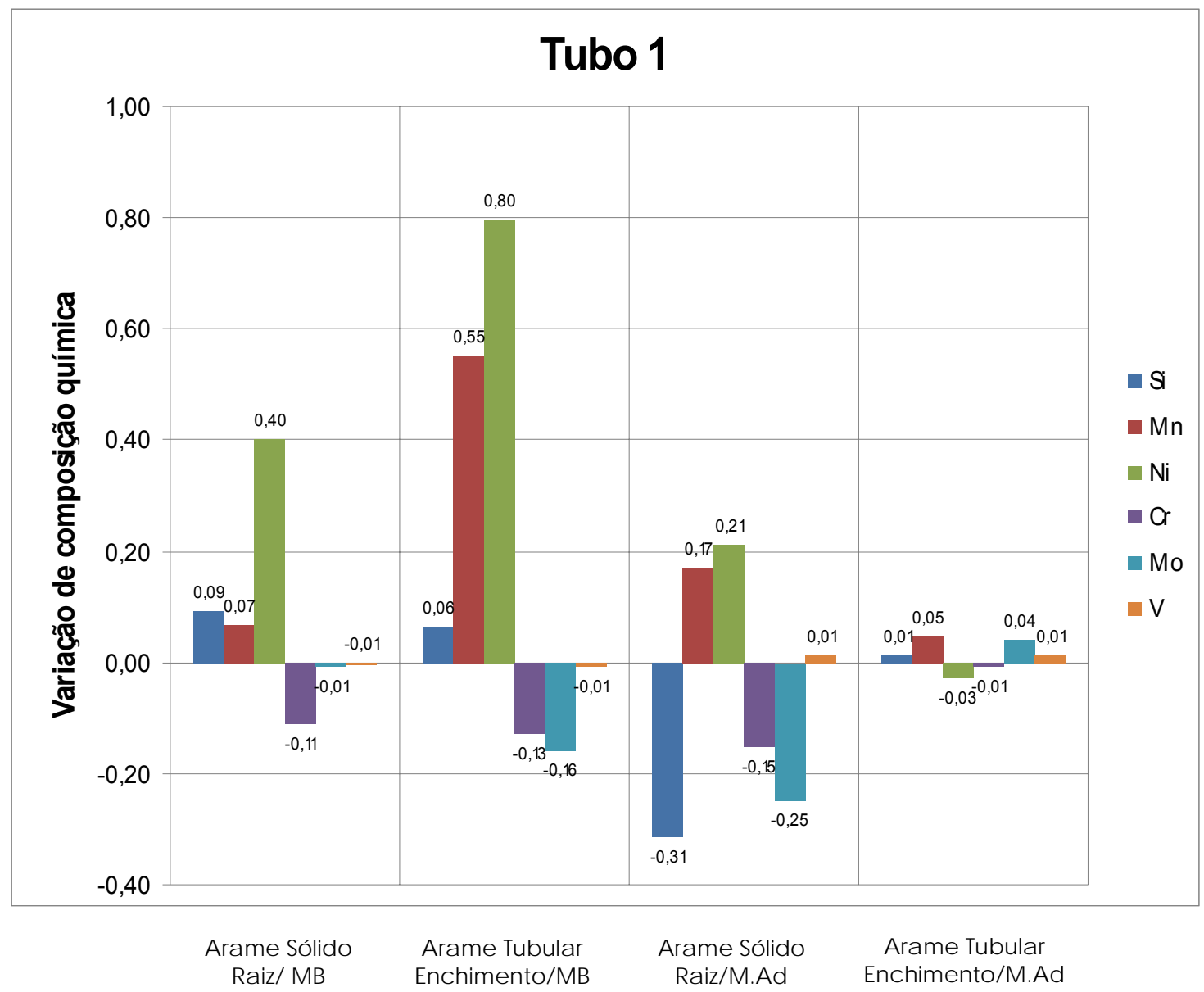

Figura 50: Variação da composição química do metal de solda em relação ao metal de base e o certificado dos consumíveis para o tubo 1. 


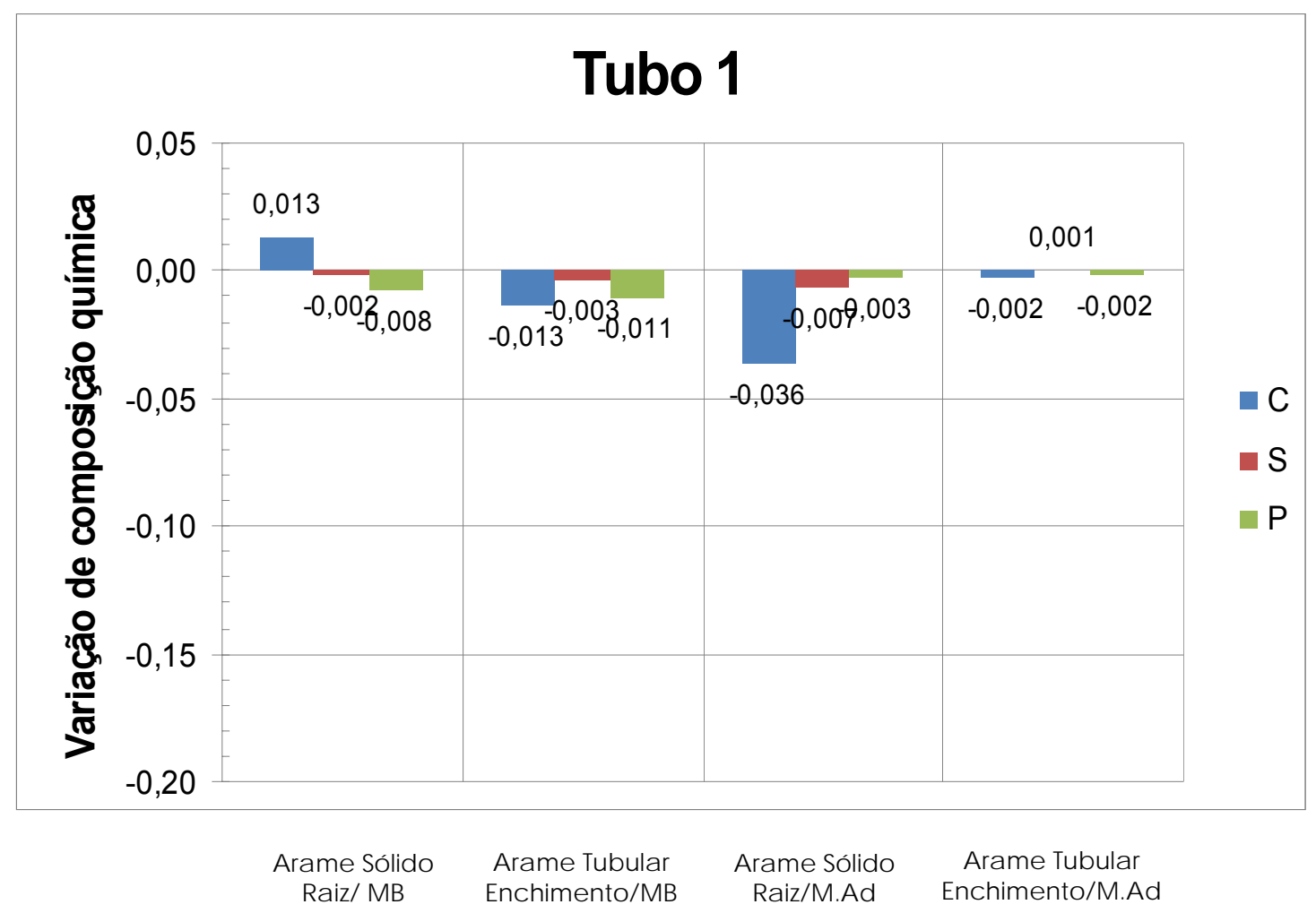

Figura 51: Variação da composição química do metal de solda em relação ao metal de base e o certificado dos consumíveis para o tubo 1.

Pela análise da figura 50 observa-se que entre o metal de solda depositado do arame sólido da raiz em relação ao metal de base houve um aumento no teor de $\mathrm{Si}, \mathrm{Mn}$ e principalmente $\mathrm{Ni}$, por outro lado houve uma redução no teor de Cr. Para os elementos Mo e $V$ não houve alteração significativa. Em relação ao metal de solda do arame tubular do enchimento, percebe-se que houve um incremento expressivo no teor de $\mathrm{Mn}$ e $\mathrm{Ni}$ em relação ao metal de base. Para os elementos $\mathrm{Cr}$ e Mo houve redução e para o Si houve um aumento modesto em comparação com o Mn e Ni. O elemento $\mathrm{V}$ também não apresentou variação significativa.

No caso da relação entre o metal de solda da raiz e o certificado do consumível, houve decréscimo no teor de $\mathrm{Si}, \mathrm{Cr}$ e Mo. Para os elementos Mn e $\mathrm{Ni}$ houve acréscimo nas quantidades destes elementos de liga. $\mathrm{O} \vee$ novamente não apresentou variação significativa. Para a relação entre o arame tubular do enchimento o certificado do consumível houve uma variação muito menor, em relação as outras comparações. O teor de $\mathrm{Mn}$ e Mo apresentaram pequeno 
incremento, enquanto que o Si e Ni apresentaram pequena redução. Para os elementos Cr e V não houve alteração significativa.

Em relação à figura 51 nota-se que houve acréscimo no teor de $C$ no metal de solda do arame sólido da raiz em relação ao metal de base. Para o $S$ e $P$ houve redução. No caso do arame tubular em relação ao metal de base houve decréscimo no teor dos elementos $\mathrm{C}, \mathrm{S}$ e $\mathrm{P}$, de maior intensidade para os elementos $\mathrm{C}$ e $\mathrm{P}$. Já para a relação entre o metal de solda depositado pelo arame sólido na raiz em comparação com o certificado do consumível nota-se que houve maior decréscimo de $\mathrm{C}$ em comparação com os elementos $\mathrm{S}$ e $\mathrm{P}$. Para a relação entre o metal de solda do arame tubular do enchimento e o certificado do consumível houve variação não significativa dos elementos $C, S$ e P.

As figuras 52 e 53 apresentam a variação da composição química do metal de solda, tanto da raiz quanto do enchimento, em relação à composição química do metal de base e do certificado do consumível para o tubo 2 .

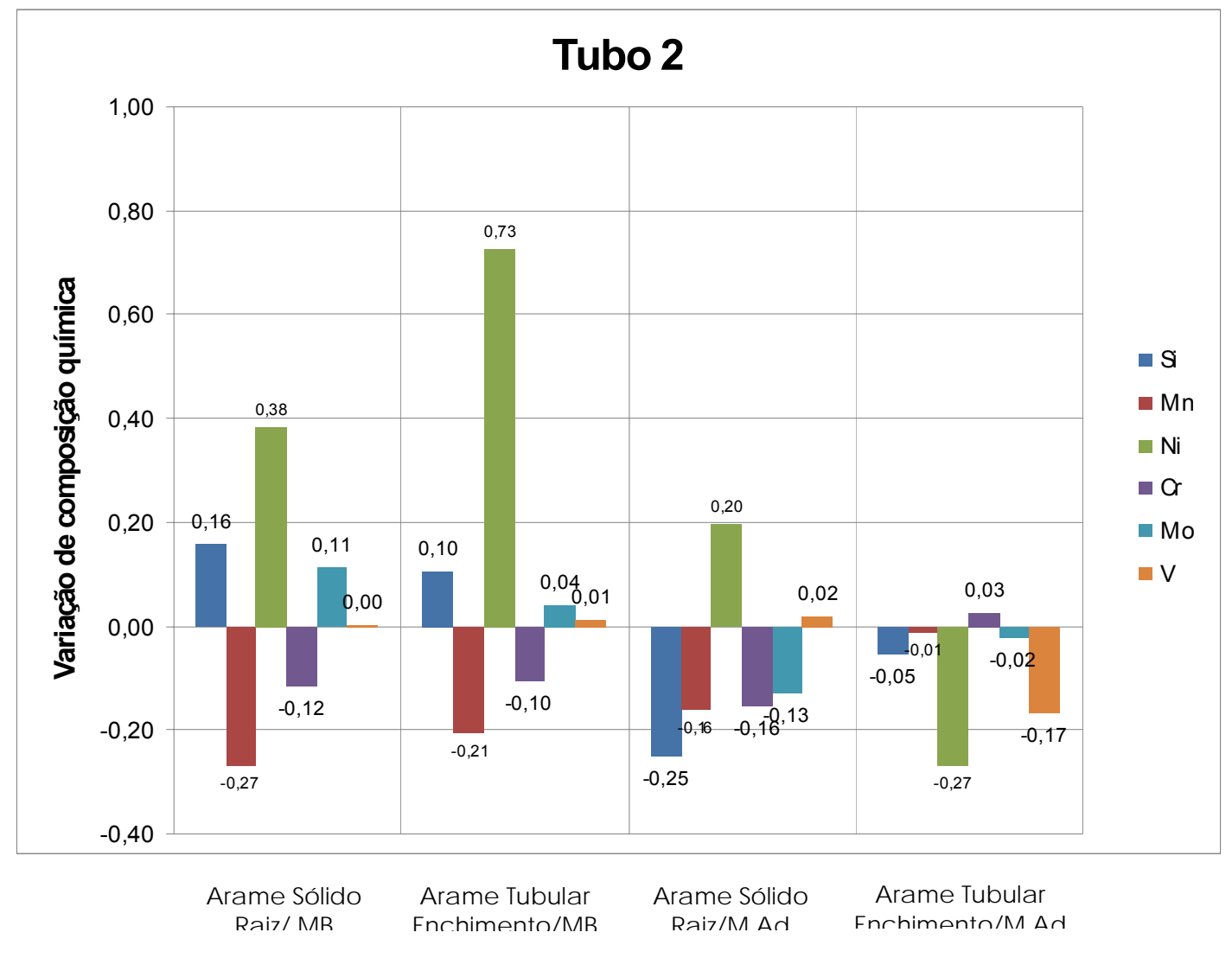

Figura 52: Variação da composição química do metal de solda em relação ao metal de base e o certificado dos consumíveis para o tubo 2. 


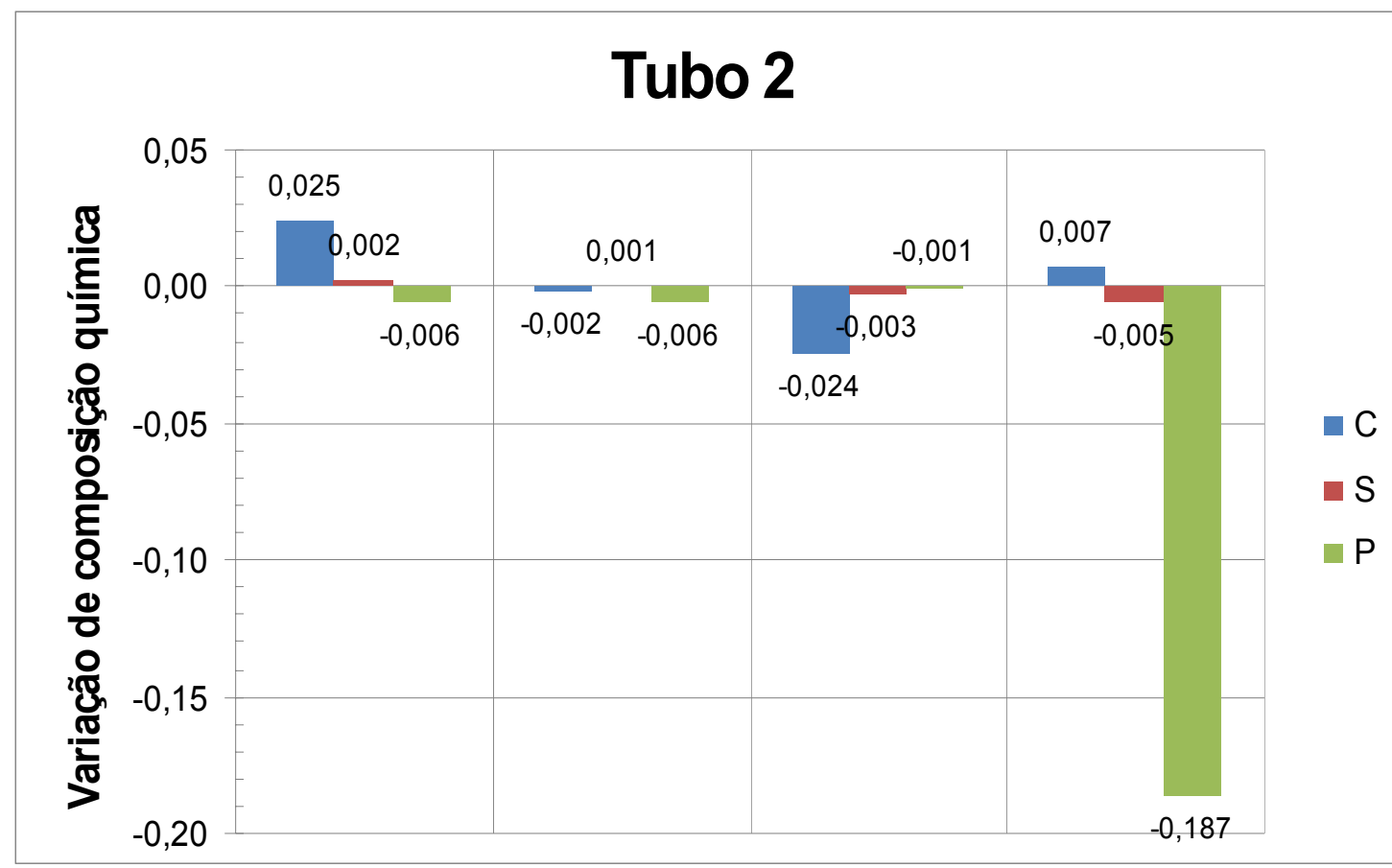

Figura 53: Variação da composição química do metal de solda em relação ao metal de base e o certificado dos consumíveis para o tubo 2 .

Pela análise da figura 52, observa-se que entre o metal de solda depositado do arame sólido da raiz em relação ao metal de base houve um aumento no teor de $\mathrm{Si}$, Mo e principalmente $\mathrm{Ni}$, por outro lado houve uma redução no teor de $\mathrm{Cr}$ e principalmente $\mathrm{Mn}$, ao contrário do tubo 1. Para o elemento $V$ não houve alteração significativa. Em relação ao metal de solda do arame tubular utilizado no enchimento, percebe-se que houve um incremento expressivo no teor de $\mathrm{Ni}$ em relação ao metal de base. Para os elementos $\mathrm{Cr}$ e Mn houve redução, ao contrário do tubo 1. Para o Si houve um aumento modesto, comparado ao $\mathrm{Ni}$. $\mathrm{O}$ elemento $\mathrm{V}$ também não apresentou variação significativa.

No caso da relação entre o metal de solda da raiz e o certificado do consumível, houve decréscimo no teor de $\mathrm{Si}, \mathrm{Mn}, \mathrm{Cr}$, Mo e $\mathrm{V}$. Para os elementos $\mathrm{V}$ e Ni houve acréscimo, especialmente para o Ni. Para a relação entre o arame tubular do enchimento e o certificado de $\mathrm{Si}, \mathrm{Mn}$, Mo, Ni e V apresentaram decréscimo, principalmente os dois últimos, enquanto que o teor 
de $\mathrm{Cr}$ apresentou acréscimo. Ao contrário das outras comparações, o $\mathrm{V}$ apresentou uma variação significativa.

Em relação à figura 53 nota-se que houve acréscimo no teor de $C$ no metal de solda do arame sólido da raiz em relação ao metal de base. Para o $\mathrm{S}$ e $P$ houve redução. No caso do arame tubular em relação ao metal de base houve decréscimo no teor dos elementos $\mathrm{C}, \mathrm{S}$ e $\mathrm{P}$, de maior intensidade para os elementos $\mathrm{C}$ e $\mathrm{P}$. Já para a relação entre o metal de solda depositado pelo arame sólido na raiz em comparação com o certificado do consumível nota-se que houve maior decréscimo de $\mathrm{C}$ em comparação com os elementos $\mathrm{S}$ e $\mathrm{P}$. Para a relação entre o metal de solda do arame tubular do enchimento e o certificado do consumível houve variação não significativa dos elementos $C, S$ e $P$.

\subsubsection{Análise do carbono equivalente:}

A figura 54 apresenta a variação do carbono equivalente segundo cada composição química do metal de solda depositada em relação ao metal de base (tabela 16), a partir dos dados da tabela 25.

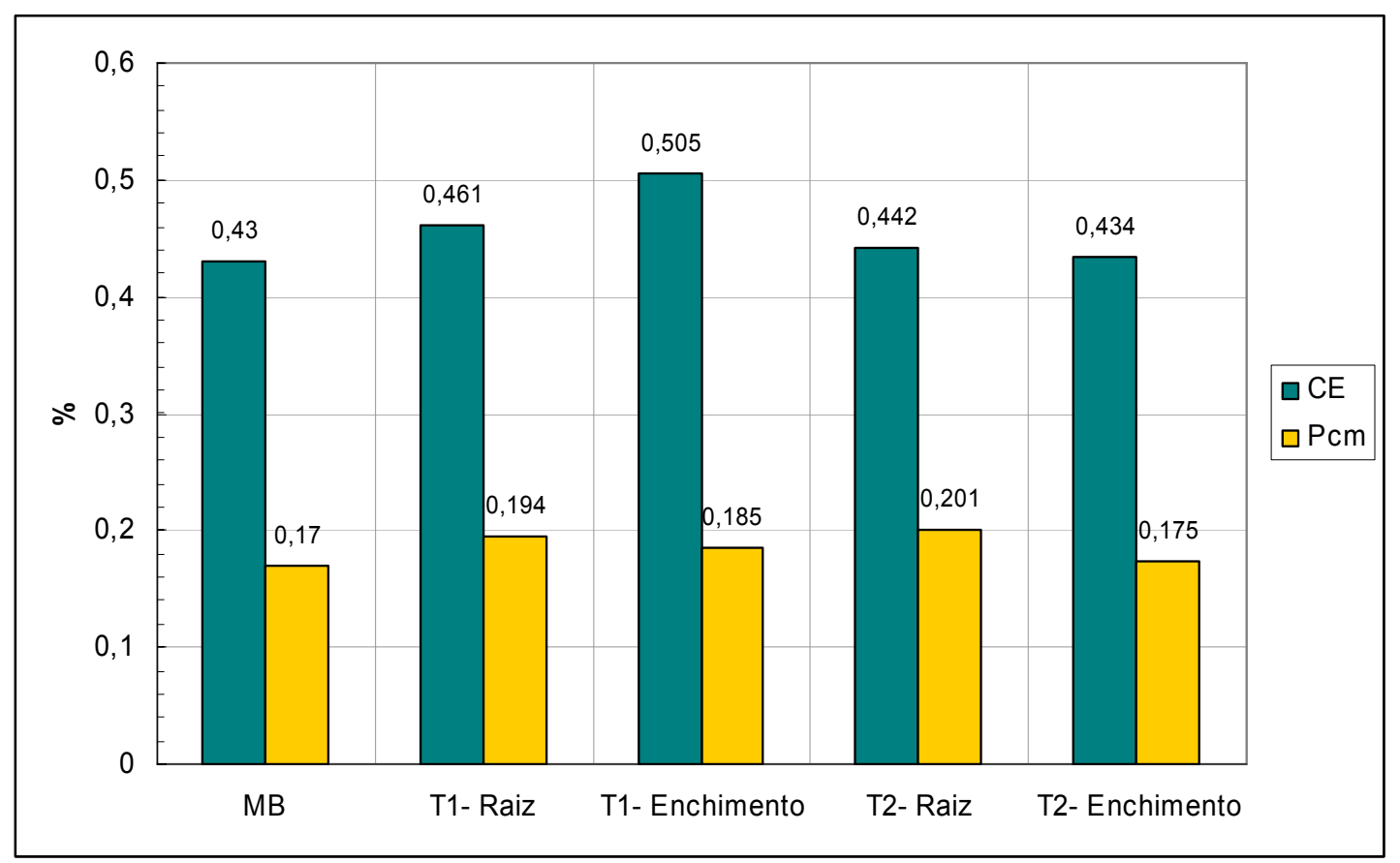

Figura 54: Variação do carbono equivalente segundo composição química do metal de solda em relação ao metal de base. 
Pela análise dos dados da figura 54, observa-se que houve aumento do carbono equivalente ( $C E)$ e do parâmetro do carbono equivalente $(\mathrm{Pcm})$ para todos os metais de solda depositados. O maior valor de carbono equivalente encontrado foi de 0,505 no enchimento do tubo1, e o maior valor do parâmetro de carbono equivalente encontrado foi de 0,201 na raiz do tubo 2 .

Esta discrepância encontrada nos valores é devida a variação da composição química e aos pesos dos elementos das fórmulas utilizadas. No caso do cálculo do carbono equivalente, o maior teor de $\mathrm{Mn}$ do enchimento do tubo 1 provocou um aumento significativo do resultado, pois na fórmula do $\mathrm{CE}$ o Mn é divido por 6, exercendo maior influência. Por outro lado, no cálculo do parâmetro de carbono equivalente, este foi influenciado pelo teor do Si e Mo da raiz do tubo 2, pois segundo a fórmula do parâmetro do carbono equivalente, $\mathrm{o}$ Mo e o Si são divididos por 15 e 30 , respectivamente, exercendo maior influência no $\mathrm{Pcm}$.

A norma API 5L [9] cita que o cálculo do carbono equivalente para aços contendo teor menor de $0,12 \%$ de carbono seja realizado pela fórmula do parâmetro do carbono equivalente. Analisando-se os dados do parâmetro do carbono equivalente, percebe-se que estes representam mais fielmente os demais resultados obtidos.

Tanto o CE como o Pcm estão relacionados com a temperabilidade do aço. Quanto maior os seus valores mais temperável é o material e, conseqüentemente, maior a sua fragilidade. Analisando somente por este ponto de vista, o tubo 1 deve apresentar resultados piores que o tubo 2. Outros fatores devem sem analisados para se ter uma posição definitiva.

Nas equações do $\mathrm{CE}$ e do $\mathrm{Pcm}$ não estão contemplados elementos como por exemplo o $\mathrm{P}$ e o $\mathrm{Sn}$, que são elementos que segregam para os contornos de grão da austenita anterior, fragilizando o material. Por este ponto de vista, os valores da energia absorvida no ensaio de impacto tendem a ser um pouco menores no tubo 2 que no tubo 1 .

Da mesma maneira o $\mathrm{O}$ e o $\mathrm{N}$ não estão presentes nas equações mas são elementos químicos que também afetam as propriedades mecânicas dos materiais. 
O teor mais elevado de $\mathrm{O}$ nos cordões do tubo 2 indica que existe uma quantidade maior de micro-inclusões no metal de solda, afetando as propriedades mecânicas.

$\mathrm{O}$ teor elevado de $\mathrm{N}$ também fragiliza $\mathrm{o}$ aço, podendo produzir carbonetos ou nitretos de elementos de liga como $\mathrm{Ti}, \mathrm{Nb}$ e $\mathrm{V}$. Pelos resultados obtidos, o tubo 1 deve apresentar valores de resistência ao impacto menores que o tubo 2, principalmente nos passes de enchimento.

\subsection{Análise térmica:}

\subsubsection{Parâmetros médios de soldagem:}

Pela análise da tabela 23 pode-se observar que a soldagem do tubo 1 apresentou de 6 a 8 camadas entre os passes de raiz e de enchimento e acabamento, sendo que os quadrantes 1 e 2 (Q1 e Q2) apresentaram 6 camadas e os quadrantes 3 e 4 (Q3 e Q4) apresentaram 8 camadas. O maior número de camadas dos quadrantes 3 e 4 devem-se ao fato da necessidade de reparos durante a soldagem.

A camada 1 corresponde ao passe de raiz da solda e a camada 6 (Q1 e Q2) e 8 ( $Q 3$ e Q4) referem-se aos passes de acabamento. As demais camadas correspondem aos passes de enchimento.

Pela análise dos valores de Energia de soldagem, pode-se observar que a camada 1 (Raiz-Processo MAG-TC), apresentou a energia de soldagem mais baixa do que a das demais camadas (Processo AT-AP), devido principalmente a corrente média menor empregada pelo processo. Este valor de corrente média deve-se ao processo empregado, pois é função dos valores de corrente de base, pico e tail-out. $O$ quadrante 3 apresentou a menor energia de soldagem entre todos os quadrantes, devido principalmente a velocidade de soldagem maior e a corrente média menor. Já o quadrante 4 apresentou a maior energia de soldagem devido à menor velocidade de soldagem e corrente média maior. 
Pela equação do cálculo da energia de soldagem, pode-se concluir que o fator velocidade de soldagem exerce grande influência no cálculo da energia de soldagem.

Em relação às camadas de enchimento e acabamento a energia de soldagem variou entre 2852,3 J/cm (camada 3, quadrante 4) a 5566,2 J/cm (camada 5, quadrante 1 ), tendo como principal influência a velocidade de soldagem de $1,38 \mathrm{~cm} / \mathrm{s}$ e $0,62 \mathrm{~cm} / \mathrm{s}$, respectivamente. Esta variação na velocidade de soldagem, em relação aos outros passes, pode estar relacionada à variação na oscilação do eletrodo, pois uma maior oscilação resulta na queda da velocidade de soldagem e por conseqüência, em maior energia de soldagem.

Pela tabela 24, pode-se observar que a soldagem do tubo 2 necessitou de 7 camadas em todos os quadrantes, englobando os passes de raiz, enchimento e acabamento, onde a camada 1 corresponde ao passe de raiz e a camada 7 aos passes de acabamento. As demais camadas correspondem aos passes de enchimento.

Através da análise dos valores de Energia de soldagem, pode-se observar que a camada 1 (Raiz - processo MAG-TC) também apresentou energia de soldagem mais baixa, variando entre $1644,2 \mathrm{~J} / \mathrm{cm}$ no quadrante 3 e $2483,3 \mathrm{~J} / \mathrm{cm}$ no quadrante 4 , em relação as demais camadas (processo ATPG), também devido principalmente a corrente média menor.

O quadrante 3 apresentou o menor valor frente aos outros quadrantes devido principalmente a maior velocidade de soldagem e corrente média menor. Por outro lado, o quadrante 4 foi o que apresentou maior energia de soldagem devido principalmente a menor velocidade de soldagem e maior corrente média.

Em relação às camadas de enchimento e acabamento, a energia de soldagem variou entre 2452 (camada 7, quadrante 1) e 4136,2 (camada 3, quadrante 4), tendo como principal influência a velocidade de soldagem, de 1,08 e $0,59 \mathrm{~cm} / \mathrm{s}$, respectivamente. Esta variação na energia de soldagem pode estar relacionada à variação na oscilação do eletrodo durante a soldagem.

Pela análise em conjunto das duas tabelas, pode-se observar que a Energia de soldagem da camada 1 foi próxima para ambos os tubos e sempre menor que as demais camadas, apresentando tendência de ser maior para 
ambos no quadrante 4 e menor no quadrante 3. Uma explicação possível para este fenômeno está relacionada ao posicionamento e a desenvoltura do soldador.

Em relação às camadas de enchimento e acabamento, pode-se observar que as energias de soldagem também foram próximas, pois embora a corrente tenha sido maior no tubo 1 e menor no tubo 2, para a tensão ocorreu o contrário, permitindo desta forma a proximidade nos valores de Energia de soldagem.

\subsubsection{Cálculo do tempo de resfriamento $\Delta t_{8-5:}$}

A partir dos dados da tabela 23 calculou-se o tempo de resfriamento entre 800 a $500^{\circ} \mathrm{C}$ no centro do cordão, utilizando-se a equação (04). A tabela 26 apresenta o tempo de resfriamento para cada camada, segundo seus respectivos quadrantes, e a figura 55 apresenta graficamente os tempos de resfriamento da tabela 26.

De acordo com a figura 55 e os respectivos dados na tabela 26 , pode-se observar que o tempo de resfriamento do passe de raiz (camada 1) em todos os quadrantes, é menor em relação às demais camadas. O menor valor encontrado foi no quadrante $3(16,8 \mathrm{~s})$, seguido-se do quadrante $1(17,2 \mathrm{~s})$, quadrante $2(21,1 \mathrm{~s})$ e quadrante $4(24,0 \mathrm{~s})$.

Esta diferença nos tempos de resfriamento é devida a combinação dos fatores Energia de soldagem e pré-aquecimento, sendo que os tempos de resfriamento encontrados em cada quadrante condizem com os valores de Energia de soldagem e pré-aquecimento encontrados.

Deste modo, analisando-se somente o tempo de resfriamento, nota-se que o quadrante 3 apresenta a maior tendência de formação de microestruturas frágeis, seguido dos quadrantes 1,2 e 4. 
Tábela 26 - Cálculo do $\Delta t_{8-5}$ para o tubo 1.

\begin{tabular}{|c|c|c|c|c|c|}
\hline Quadrante & Camada & $\mathrm{T}_{\text {pré }}\left({ }^{\circ} \mathrm{C}\right)$ & $\mathrm{T}_{\text {interpasse }}\left({ }^{\circ} \mathrm{C}\right)$ & $\mathrm{E}_{\text {soldagem }}(\mathrm{J} / \mathrm{cm})$ & $\Delta \mathrm{t}_{8-5}(\mathrm{~s})$ \\
\hline \multirow{6}{*}{1} & 1 & 155,3 & 178,0 & 1995,0 & 17,2 \\
\hline & 2 & 175,3 & 209,3 & 4581,5 & 42,1 \\
\hline & 3 & 172,7 & 205,0 & 3483,9 & 37,9 \\
\hline & 4 & 172,7 & 224,3 & 4059,8 & 48,9 \\
\hline & 5 & 170,3 & 194,0 & 5566,2 & 57,4 \\
\hline & 6 & 160,0 & 190,7 & 5428,9 & 55,0 \\
\hline Quadrante & Camada & $\mathrm{T}_{\text {pré }}\left({ }^{\circ} \mathrm{C}\right)$ & $\mathrm{T}_{\text {interpasse }}\left({ }^{\circ} \mathrm{C}\right)$ & $\mathrm{E}_{\text {soldagem }}(\mathrm{J} / \mathrm{cm})$ & $\Delta \mathrm{t}_{8-5}(\mathrm{~s})$ \\
\hline \multirow{6}{*}{2} & 1 & 178,0 & 161,7 & 2206,6 & 21,1 \\
\hline & 2 & 168,3 & 223,3 & 4521,1 & 54,1 \\
\hline & 3 & 160,0 & 212,0 & 3326,3 & 37,5 \\
\hline & 4 & 158,7 & 182,0 & 4904,0 & 47,7 \\
\hline & 5 & 173,7 & 167,0 & 3953,9 & 35,8 \\
\hline & 6 & 169,0 & 208,0 & 4068,7 & 45,0 \\
\hline Quadrante & Camada & $\mathrm{T}_{\text {pré }}\left({ }^{\circ} \mathrm{C}\right)$ & $\mathrm{T}_{\text {interpasse }}\left({ }^{\circ} \mathrm{C}\right)$ & $\mathrm{E}_{\text {soldagem }}(\mathrm{J} / \mathrm{cm})$ & $\Delta \mathrm{t}_{8-5}(\mathrm{~s})$ \\
\hline \multirow{8}{*}{3} & 1 & 159,3 & 212,7 & 1921,4 & 16,8 \\
\hline & 2 & 177,7 & 227,0 & 4447,3 & 54,3 \\
\hline & 3 & 178,3 & 196,7 & 4026,6 & 42,0 \\
\hline & 4 & 170,0 & 160,0 & 3856,3 & 33,9 \\
\hline & 5 & 160,3 & 181,0 & 4486,8 & 39,9 \\
\hline & 6 & 172,7 & 193,3 & 3332,6 & 34,2 \\
\hline & 7 & 156,3 & 168,3 & 3206,3 & 29,2 \\
\hline & 8 & 159,7 & 164,3 & 3779,5 & 33,8 \\
\hline Quadrante & Camada & $\mathrm{T}_{\text {pré }}\left({ }^{\circ} \mathrm{C}\right)$ & $\mathrm{T}_{\text {interpasse }}\left({ }^{\circ} \mathrm{C}\right)$ & $\mathrm{E}_{\text {soldagem }}(\mathrm{J} / \mathrm{cm})$ & $\Delta \mathrm{t}_{8-5}(\mathrm{~s})$ \\
\hline \multirow{8}{*}{4} & 1 & 181,7 & 165,3 & 2469,9 & 24,0 \\
\hline & 2 & 173,7 & 202,7 & 3757,2 & 40,4 \\
\hline & 3 & 173,7 & 210,7 & 2852,3 & 32,0 \\
\hline & 4 & 161,7 & 186,0 & 3934,3 & 32,0 \\
\hline & 5 & 182,7 & 204,7 & 3392,8 & 36,9 \\
\hline & 6 & 167,7 & 182,7 & 4078,4 & 39,8 \\
\hline & 7 & 157,0 & 167,3 & 3867,8 & 28,8 \\
\hline & 8 & 165,7 & 173,7 & 3457,0 & 32,3 \\
\hline
\end{tabular}

Nota: o $\Delta \mathrm{t}_{8-5}$ foi calculado no centro do cordão de solda, utilizando-se a Eq. (04) [58]. 


\section{Tubo 1}

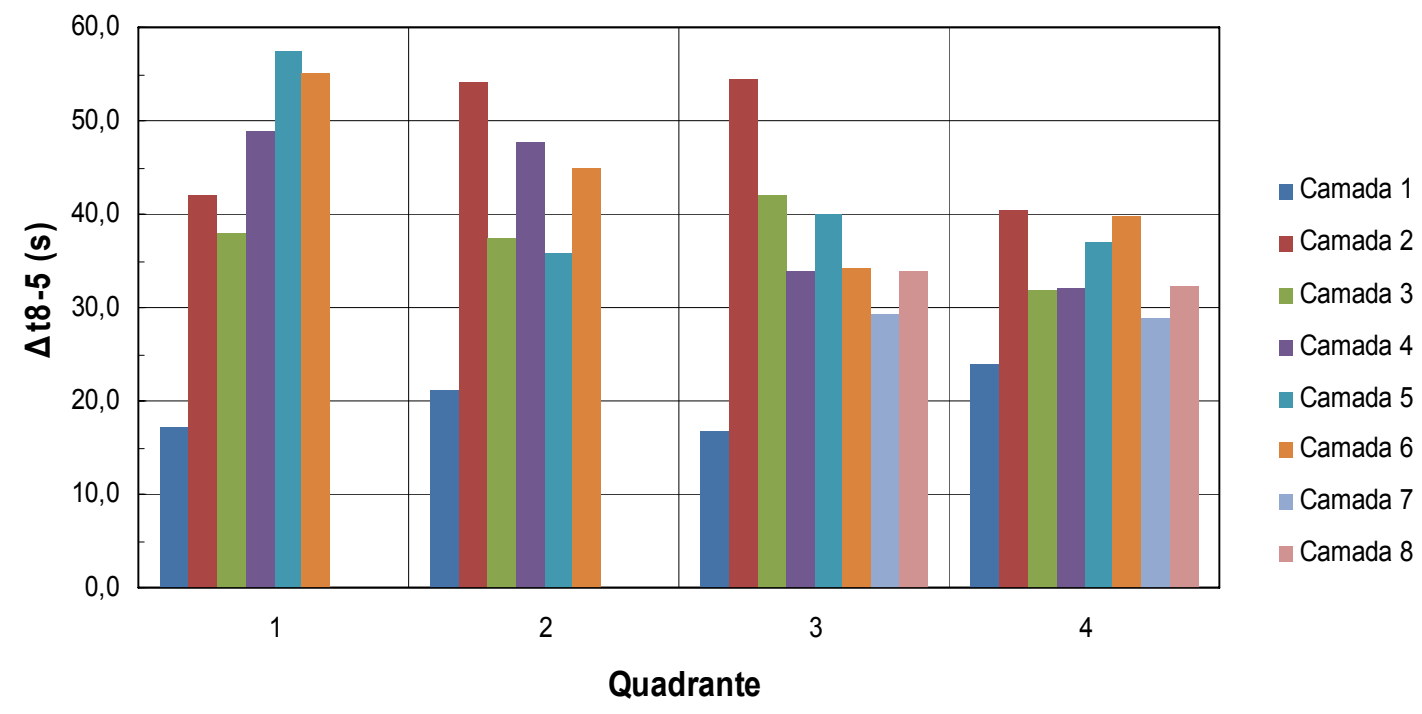

Figura 55: Tempo de resfriamento entre 800 e $500^{\circ} \mathrm{C}$, de acordo com os dados da tabela 26.

Em relação às camadas de enchimento e acabamento pode-se observar que o tempo de resfriamento variou entre $28,2 \mathrm{~s}$ na camada 7 do quadrante $4 \mathrm{e}$ 57,4 s na camada 5 do quadrante 1 . A camada 2 possui a tendência de possuir o maior tempo de resfriamento em todos os quadrantes, a exceção do quadrante 1 , onde o maior tempo de resfriamento ocorreu na camada 5. A camada 3 apresentou tempo de resfriamento menor em todos os quadrantes, em relação à camada 2 .

A camada 4 apresentou tempo de resfriamento maior nos quadrantes 1 e 2, mas nos quadrantes 3 e 4, foi menor e igual, respectivamente. Já a camada 5 apresentou tendência de aproximar-se em todos os quadrantes, exceto no quadrante 1. A camada 6 exibiu tendência de aproximar-se da camada $5 \mathrm{em}$ todos os quadrantes, ficando abaixo desta nos quadrantes 1 e 3 , sendo que nos demais ficou acima. As camadas 7 e 8 dos quadrantes 3 e 4 apresentaram tendência de manterem-se iguais em ambos os quadrantes e inferior a camada 6 de todos os quadrantes.

Deste modo, nota-se que as camadas que apresentaram menor tempo de resfriamento tendem a formar microestruturas mais frágeis, especialmente as camadas 3 do quadrante 1,5 do quadrante 2,7 dos quadrantes 3 e 4 . 
A partir dos dados da tabela 24 calculou-se o tempo de resfriamento entre 800 a $500^{\circ} \mathrm{C}$. A tabela 27 apresenta o tempo de resfriamento para cada camada, segundo seus respectivos quadrantes, e a figura 56 apresenta graficamente os tempos de resfriamento da tabela 27.

Tábela 27 - Cálculo do $\Delta t_{8-5}$ para o tubo 2.

\begin{tabular}{|c|c|c|c|c|c|}
\hline Quadrante & Camada & $\mathrm{T}_{\text {pré }}\left({ }^{\circ} \mathrm{C}\right)$ & $\mathrm{T}_{\text {interpasse }}\left({ }^{\circ} \mathrm{C}\right)$ & $\mathrm{E}_{\text {soldagem }}(\mathrm{J} / \mathrm{cm})$ & $\Delta \mathrm{t}_{8-5}(\mathrm{~s})$ \\
\hline \multirow{7}{*}{1} & 1 & 152,0 & 192,7 & 2043,1 & 17,3 \\
\hline & 2 & 174,0 & 222,7 & 2790,6 & 33,3 \\
\hline & 3 & 171,7 & 235,0 & 4041,0 & 51,6 \\
\hline & 4 & 111,0 & 175,0 & 2659,4 & 25,0 \\
\hline & 5 & 155,7 & 192,7 & 3208,3 & 32,8 \\
\hline & 6 & 161,7 & 175,3 & 3243,3 & 30,6 \\
\hline & 7 & 166,7 & 207,0 & 2452,0 & 27,0 \\
\hline Quadrante & Camada & $\mathrm{T}_{\text {pré }}\left({ }^{\circ} \mathrm{C}\right)$ & $\mathrm{T}_{\text {interpasse }}\left({ }^{\circ} \mathrm{C}\right)$ & $E_{\text {soldagem }}(\mathrm{J} / \mathrm{cm})$ & $\Delta \mathrm{t}_{8-5}(\mathrm{~s})$ \\
\hline \multirow{7}{*}{2} & 1 & 175,0 & 124,3 & 2300,5 & 21,6 \\
\hline & 2 & 167,7 & 233,3 & 3191,7 & 40,4 \\
\hline & 3 & 178,7 & 224,7 & 4094,8 & 49,4 \\
\hline & 4 & 157,7 & 205,7 & 2937,7 & 32,1 \\
\hline & 5 & 166,3 & 183,0 & 3079,9 & 30,1 \\
\hline & 6 & 167,0 & 201,3 & 3946,1 & 42,2 \\
\hline & 7 & 164,7 & 201,7 & 2895,9 & 31,0 \\
\hline Quadrante & Camada & $\mathrm{T}_{\text {pré }}\left({ }^{\circ} \mathrm{C}\right)$ & $\mathrm{T}_{\text {interpasse }}\left({ }^{\circ} \mathrm{C}\right)$ & $E_{\text {soldagem }}(\mathrm{J} / \mathrm{cm})$ & $\Delta \mathrm{t}_{8-5}(\mathrm{~s})$ \\
\hline \multirow{7}{*}{3} & 1 & 199,0 & 202,3 & 1644,2 & 17,4 \\
\hline & 2 & 165,3 & 194,7 & 2494,3 & 25,8 \\
\hline & 3 & 155,7 & 163,0 & 2392,5 & 21,3 \\
\hline & 4 & 181,0 & 215,0 & 3023,3 & 34,7 \\
\hline & 5 & 164,7 & 211,3 & 3055,9 & 34.4 \\
\hline & 6 & 163,7 & 217,3 & 3017,8 & 35,0 \\
\hline & 7 & 160,0 & 181,0 & 3647,3 & 35,3 \\
\hline Quadrante & Camada & $\mathrm{T}_{\text {pré }}\left({ }^{\circ} \mathrm{C}\right)$ & $\mathrm{T}_{\text {interpasse }}\left({ }^{\circ} \mathrm{C}\right)$ & $E_{\text {soldagem }}(\mathrm{J} / \mathrm{cm})$ & $\Delta \mathrm{t}_{8-5}(\mathrm{~s})$ \\
\hline \multirow{7}{*}{4} & 1 & 166,7 & 165,3 & 2483,3 & 22,5 \\
\hline & 2 & 168,7 & 228,3 & 2530,7 & 31,1 \\
\hline & 3 & 180,3 & 242,0 & 4136,2 & 54,9 \\
\hline & 4 & 164,3 & 189,0 & 3147,3 & 31,6 \\
\hline & 5 & 167,7 & 174,3 & 2716,5 & 25,5 \\
\hline & 6 & 172,7 & 209,3 & 3338,0 & 37,2 \\
\hline & 7 & 155,7 & 184,0 & 3246,4 & 31,9 \\
\hline
\end{tabular}

Nota: o $\Delta t_{8-5}$ foi calculado no centro do cordão de solda, utilizando-se a Eq. (04) [58]. 


\section{Tubo 2}

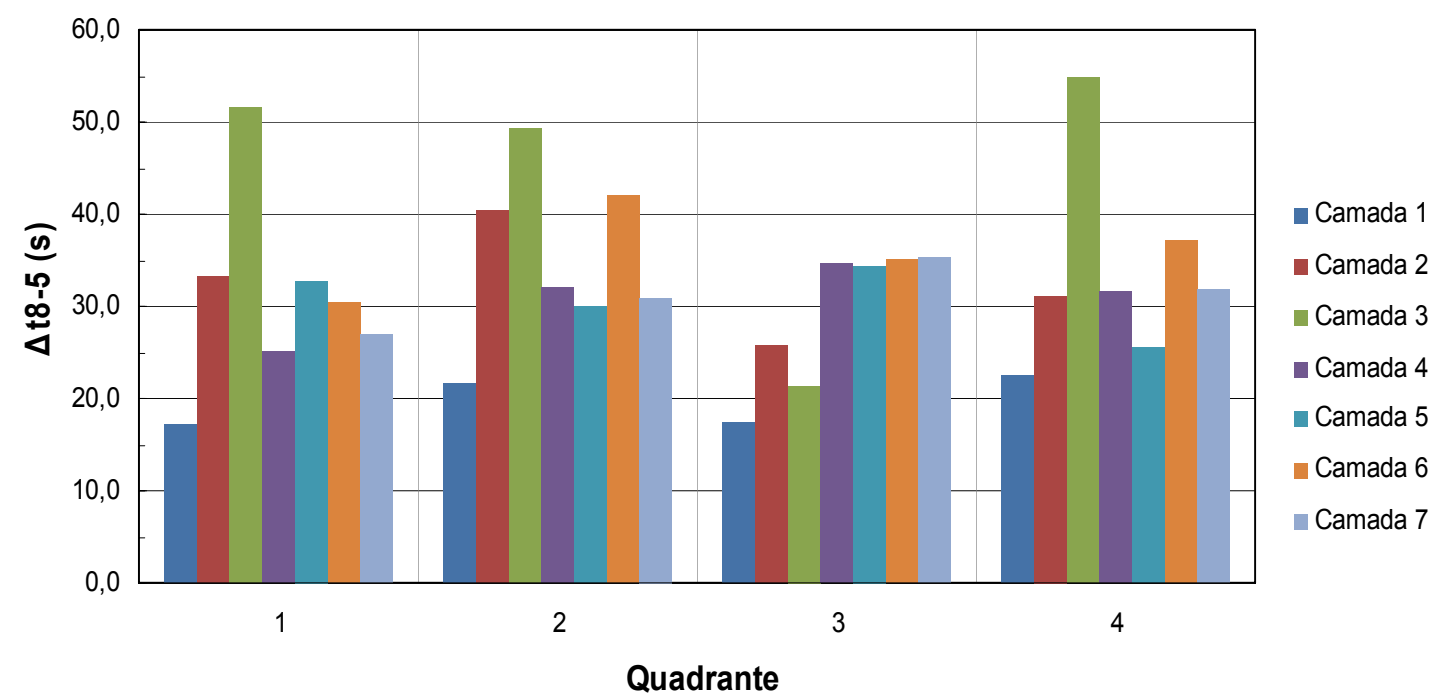

Figura 56: Tempo de resfriamento entre 800 e $500^{\circ} \mathrm{C}$, de acordo com os dados da tabela 27.

De acordo com a figura 56 e os dados da tabela 27 , observa-se que o tempo de resfriamento do passe de raiz (camada 1) foram consideravelmente menor que os tempos das camadas de enchimento e acabamento, sendo que 0 menor valor foi encontrado no quadrante $1(17,3 \mathrm{~s})$ seguido pelos quadrantes 3 $(17,4 s), 2$ (21,6s) e $4(22,5 s)$. Os tempos de resfriamento encontrados condizem com os valores de Energia de soldagem pré-aquecimento encontrados.

Deste modo, analisando-se somente o tempo de resfriamento, pode-se notar que os quadrantes 1 e 3 possuem maior tendência a formação de microestruturas frágeis, devido ao tempo de resfriamento praticamente igual para ambos, seguindo-se dos quadrantes 2 e 4.

Em relação às camadas de enchimento e acabamento, pode-se observar que o tempo de resfriamento variou entre 21,3s na camada 3 do quadrante 3 e 54,9s na camada 3 do quadrante 4 .

A camada 2 apresentou tendência de possuir menor tempo de resfriamento que a camada $3 \mathrm{em}$ todos os quadrantes, exceto no quadrante 3 , onde a camada 2 apresentou maior tempo. A camada 3 apresentou tendência de possuir o maior tempo de resfriamento em todos os quadrantes, a exceção do quadrante 3.

A camada 4, tal como a camada 2, apresentou menor tempo de resfriamento em todos os quadrantes, a exceção do quadrante 3. A camada 5 
apresentou tempo de resfriamento menor do que a camada 4 em todos os quadrantes, a exceção do quadrante 1. As camadas 6 e 7 apresentaram comportamento semelhante em todos os quadrantes, exceto no quadrante 3 , onde permaneceram praticamente iguais.

Deste modo, pode-se afirmar que as camadas que apresentaram menor tempo de resfriamento tendem a formar microestruturas mais frágeis, especialmente as camadas 4 do quadrante 1,5 e 7 do quadrante 2, 3 do quadrante 3 e 5 do quadrante 4 .

Analisando-se em conjunto a figuras 55 e 56 e os dados das tabelas 26 e 27, pode-se observar que o tempo de resfriamento da camada 1 (raiz) de ambos os tubos foram próximos e notadamente menores que do que as respectivas camadas de enchimento e acabamento, o que pode acabar contribuindo, dependendo da composição química, na formação de microestruturas frágeis.

Em relação às camadas de enchimento e acabamento, a camada 2 do tubo 1 apresentou o maior tempo de resfriamento na maioria dos quadrantes, diferentemente do tubo 2 , onde a camada com o maior tempo de resfriamento na maioria dos quadrantes foi a camada 3. As camadas de acabamento apresentaram tendência de possuir tempos de resfriamento mais baixos, em ambos os tubos, do que as camadas de enchimento, podendo ocasionar a formação de microestruturas frágeis, dependendo da composição química da região da junta soldada. Neste estudo o passe de raiz foi feito com uma adição com uma determinada composição química e o enchimento e acabamento com outro consumível.

Todos os $\Delta \mathrm{t}_{8-5}$ calculados estão bem acima de $10 \mathrm{~s}$, indicando que um dos fatores para a fragilização por hidrogênio, a microestrutura favorável, não está presente em grande extensão nas regiões que sofreram transformação de fase na junta soldada.

Com os dados publicados na literatura $[26,73,74]$ foi feito o gráfico do tempo de resfriamento entre 800 e $500^{\circ} \mathrm{C}$, supondo-se uma velocidade de resfriamento linear. Os resultados estão apresentados na figura 57 . O retângulo com linha cheia representa a variação dos valores dos tempos de resfriamento calculados e o retângulo com linha tracejada representa as durezas previstas. 
Os valores da referência 57 foram desprezados devido a composição e condições experimentais em que foram realizados os experimentos.

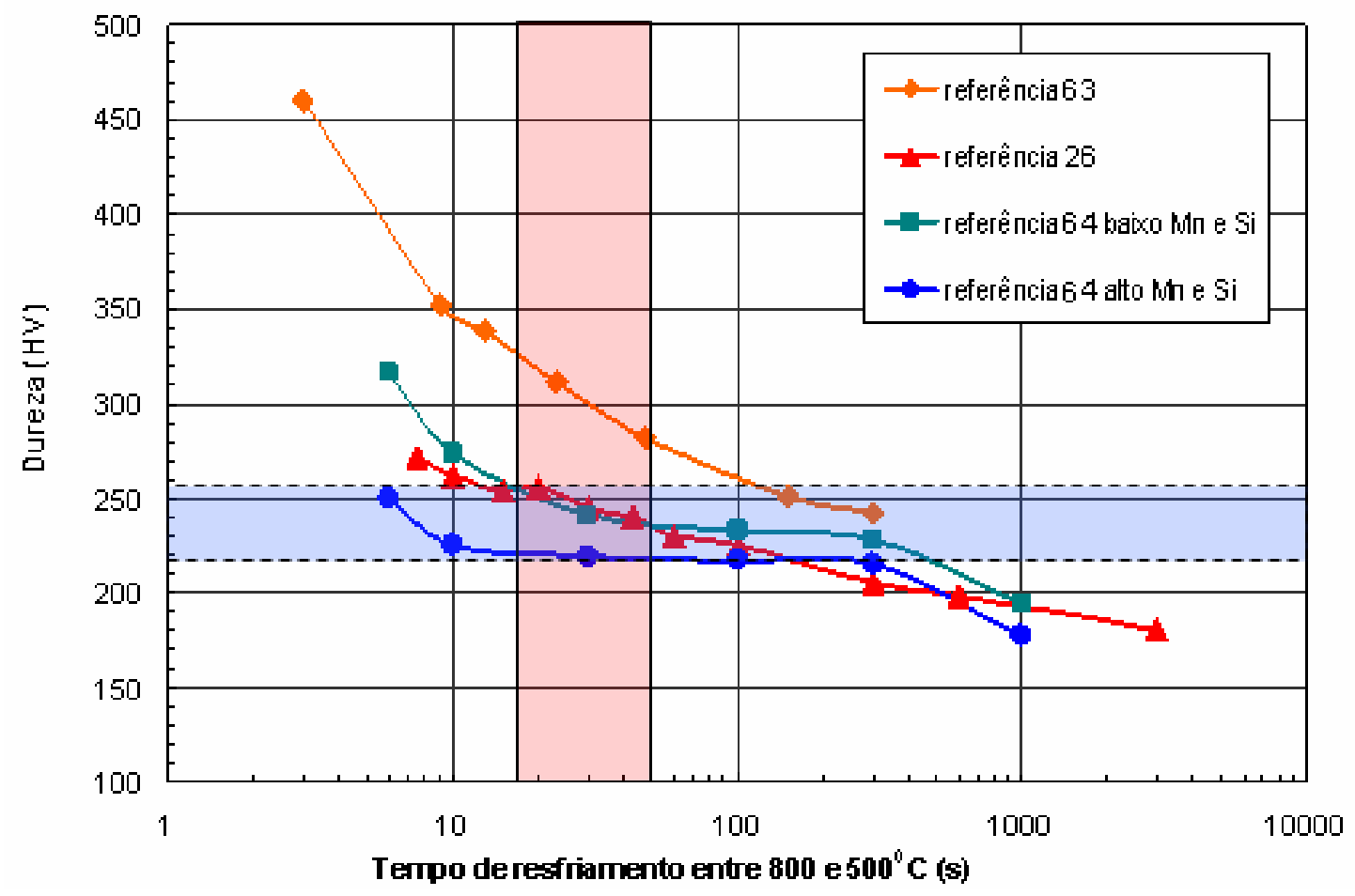

Figura 57: Dureza versus tempo de resfriamento entre 800 e $500^{\circ} \mathrm{C}$, de acordo com os dados das ref. 26, 63 e 64 .

\subsubsection{Velocidade de resfriamento:}

A partir dos dados da tabela 26 foram calculadas as velocidades de resfriamento as camadas de cada quadrante. As tabelas 28 a 31 apresentam as velocidadesde resfriamento calculadas e as figuras de 58 a 61 apresentam graficamente as respectivas velocidades de resfriamento calculadas para diversas temperaturas. 
Tabela 28 - Velocidade de resfriamento, em função dos parâmetros de soldagem, para o tubo 1, quadrante 1.

\begin{tabular}{|c|c|c|c|c|c|c|}
\hline \multicolumn{7}{|c|}{ Tubo 1 - quadrante 1} \\
\hline & Camada & Camada & Camada & Camada & Camada & Camada \\
\hline & 1 & 2 & 3 & 4 & 5 & 6 \\
\hline $\mathrm{T}_{\text {pré }}\left({ }^{\circ} \mathrm{C}\right)$ & 155,3 & 175,3 & 172,7 & 172,7 & 170,3 & 160,0 \\
\hline $\begin{array}{c}\mathrm{T}_{\text {interpasse }} \\
\left({ }^{\circ} \mathrm{C}\right)\end{array}$ & 178,0 & 209,3 & 205,0 & 224,3 & 194,0 & 190,7 \\
\hline $\begin{array}{c}E_{\text {soldagem }} \\
(\mathrm{J} / \mathrm{cm})\end{array}$ & 1995,0 & 3781,8 & 3483,9 & 4059,8 & 5566,2 & 5428,9 \\
\hline & \multicolumn{6}{|c|}{ Velocidade de resfriamento ${ }^{*}\left({ }^{\circ} \mathrm{C} / \mathrm{s}\right)$} \\
\hline Temp. & Camada & Camada & Camada & Camada & Camada & Camada \\
\hline$\left({ }^{\circ} \mathrm{C}\right)$ & 1 & 2 & 3 & 4 & 5 & 6 \\
\hline 1200 & 343,53 & 134,53 & 178,46 & 147,25 & 114,18 & 117,85 \\
\hline 1000 & 224,59 & 85,69 & 113,93 & 93,07 & 73,30 & 75,77 \\
\hline 971 & 197,95 & 79,52 & 105,77 & 86,24 & 68,12 & 70,44 \\
\hline 900 & 174,56 & 65,39 & 87,07 & 70,62 & 56,24 & 58,20 \\
\hline 864 & 158,09 & 58,75 & 78,28 & 63,29 & 50,65 & 52,45 \\
\hline 809 & 134,50 & 49,29 & 65,76 & 52,88 & 42,67 & 44,23 \\
\hline 800 & 130,82 & 47,82 & 63,82 & 51,26 & 41,43 & 42,95 \\
\hline 740 & 107,60 & 38,60 & 51,59 & 41,13 & 33,63 & 34,91 \\
\hline 700 & 93,38 & 33,00 & 44,17 & 35,00 & 28,89 & 30,01 \\
\hline 670 & 83,38 & 29,09 & 38,98 & 30,72 & 25,56 & 26,58 \\
\hline 600 & 62,24 & 20,92 & 28,12 & 21,83 & 18,60 & 19,38 \\
\hline 500 & 37,39 & 11,58 & 15,69 & 11,75 & 10,56 & 11,07 \\
\hline 400 & 18,84 & 4,98 & 6,85 & 4,77 & 4,79 & 5,07 \\
\hline 300 & 6,59 & 1,13 & 1,63 & 0,89 & 1,27 & 1,38 \\
\hline
\end{tabular}

$\left(^{*}\right)$ A velocidade de resfriamento foi calculada no centro do cordão de solda, supondose chapa grossa [79]. 
Tabela 29 - Velocidade de resfriamento, em função dos parâmetros de soldagem, para o tubo 1, quadrante 2.

\begin{tabular}{|c|c|c|c|c|c|c|}
\hline \multicolumn{7}{|c|}{ Tubo 1 - quadrante 2} \\
\hline & Camada & Camada & Camada & Camada & Camada & Camada \\
\hline & 1 & 2 & 3 & 4 & 5 & 6 \\
\hline $\mathrm{T}_{\text {pré }}\left({ }^{\circ} \mathrm{C}\right)$ & 178,0 & 168,3 & 160,0 & 158,7 & 173,7 & 169,0 \\
\hline $\begin{array}{c}\mathrm{T}_{\text {interpasse }} \\
\left({ }^{\circ} \mathrm{C}\right)\end{array}$ & 161,7 & 223,3 & 212,0 & 182,0 & 167,0 & 208,0 \\
\hline $\begin{array}{c}E_{\text {soldagem }} \\
(\mathrm{J} / \mathrm{cm})\end{array}$ & 2206,6 & 4521,1 & 3326,3 & 4904,0 & 3953,9 & 4068,7 \\
\hline & \multicolumn{6}{|c|}{ Velocidade de resfriamento ${ }^{*}\left({ }^{\circ} \mathrm{C} / \mathrm{s}\right)$} \\
\hline Temp. & Camada & Camada & Camada & Camada & Camada & Camada \\
\hline$\left({ }^{\circ} \mathrm{C}\right)$ & 1 & 2 & 3 & 4 & 5 & 6 \\
\hline 1200 & 297,26 & 132,50 & 184,29 & 132,71 & 169,48 & 151,89 \\
\hline 1000 & 192,30 & 83,79 & 117,23 & 85,69 & 110,21 & 96,82 \\
\hline 971 & 186,42 & 77,65 & 108,76 & 79,72 & 102,67 & 89,86 \\
\hline 900 & 148,36 & 63,60 & 89,37 & 66,02 & 85,34 & 73,91 \\
\hline 864 & 133,93 & 57,01 & 80,26 & 59,56 & 77,16 & 66,42 \\
\hline 809 & 113,32 & 47,64 & 67,29 & 50,34 & 65,46 & 55,75 \\
\hline 800 & 110,11 & 46,19 & 65,28 & 48,91 & 63,64 & 54,09 \\
\hline 740 & 89,89 & 37,08 & 52,63 & 39,87 & 52,15 & 43,68 \\
\hline 700 & 77,55 & 31,56 & 44,96 & 34,36 & 45,12 & 37,36 \\
\hline 670 & 68,89 & 27,71 & 39,60 & 30,50 & 40,19 & 32,94 \\
\hline 600 & 50,68 & 19,71 & 28,42 & 22,37 & 29,78 & 23,72 \\
\hline 500 & 29,51 & 10,63 & 15,66 & 12,95 & 17,61 & 13,16 \\
\hline 400 & 14,03 & 4,34 & 6,67 & 6,09 & 8,62 & 5,69 \\
\hline 300 & 4,24 & 0,82 & 1,46 & 1,78 & 2,81 & 1,31 \\
\hline
\end{tabular}

${ }^{*}$ ) A velocidade de resfriamento foi calculada no centro do cordão de solda, supondose chapa grossa [79]. 
Tábela 30 - Velocidade de resfriamento, em função dos parâmetros de soldagem, para o tubo 1, quadrante 3.

\begin{tabular}{|c|c|c|c|c|c|c|c|c|}
\hline \multicolumn{9}{|c|}{ Tubo 1 - quadrante 3} \\
\hline & Camada & Camada & Camada & Camada & Camada & Camada & Camada & Camada \\
\hline & 1 & 2 & 3 & 4 & 5 & 6 & 7 & 8 \\
\hline $\mathrm{T}_{\text {pré }}\left({ }^{\circ} \mathrm{C}\right)$ & 159,3 & 177,7 & 178,3 & 170,0 & 160,3 & 172,7 & 156,3 & 159,7 \\
\hline $\begin{array}{c}T_{\text {interpasse }} \\
\left({ }^{\circ} \mathrm{C}\right)\end{array}$ & 212,7 & 227,0 & 196,7 & 160,0 & 181,0 & 193,3 & 168,3 & 164,3 \\
\hline \multirow{2}{*}{$\begin{array}{c}E_{\text {soldagem }} \\
(\mathrm{J} / \mathrm{cm})\end{array}$} & 1921,4 & 4447,3 & 4026,6 & 3856,3 & 4126,4 & 3332,6 & 3206,3 & 3779,5 \\
\hline & \multicolumn{8}{|c|}{ Velocidade de resfriamento* $\left({ }^{\circ} \mathrm{C} / \mathrm{s}\right)$} \\
\hline Temp. & Camada & Camada & Camada & Camada & Camada & Camada & Camada & Camada \\
\hline$\left({ }^{\circ} \mathrm{C}\right)$ & 1 & 2 & 3 & 4 & 5 & 6 & 7 & 8 \\
\hline 1200 & 353,96 & 133,69 & 157,00 & 176,14 & 145,34 & 190,96 & 208,47 & 178,23 \\
\hline 1000 & 230,98 & 84,38 & 100,65 & 114,91 & 93,88 & 122,62 & 135,47 & 116,04 \\
\hline 971 & 187,95 & 78,16 & 93,51 & 107,11 & 87,35 & 113,96 & 126,19 & 108,12 \\
\hline 900 & 179,30 & 63,96 & 77,15 & 89,18 & 72,36 & 94,10 & 104,85 & 89,93 \\
\hline 864 & 162,29 & 57,30 & 69,46 & 80,71 & 65,29 & 84,76 & 94,79 & 81,34 \\
\hline 809 & 137,95 & 47,83 & 58,48 & 68,59 & 55,20 & 71,43 & 80,39 & 69,06 \\
\hline 800 & 134,15 & 46,36 & 56,77 & 66,70 & 53,63 & 69,35 & 78,15 & 67,14 \\
\hline 740 & 110,20 & 37,16 & 46,04 & 54,78 & 43,74 & 56,31 & 64,01 & 55,06 \\
\hline 700 & 95,54 & 31,59 & 39,51 & 47,49 & 37,70 & 48,38 & 55,36 & 47,68 \\
\hline 670 & 85,23 & 27,71 & 34,94 & 42,36 & 33,47 & 42,82 & 49,29 & 42,49 \\
\hline 600 & 63,47 & 19,65 & 25,37 & 31,53 & 24,57 & 31,16 & 36,50 & 31,54 \\
\hline 500 & 37,93 & 10,52 & 14,35 & 18,83 & 14,24 & 17,72 & 21,55 & 18,72 \\
\hline 400 & 18,93 & 4,23 & 6,45 & 9,38 & 6,71 & 8,05 & 10,51 & 9,23 \\
\hline 300 & 6,47 & 0,75 & 1,67 & 3,19 & 1,98 & 2,14 & 3,40 & 3,06 \\
\hline
\end{tabular}

$\left({ }^{*}\right)$ A velocidade de resfriamento foi calculada no centro do cordão de solda, supondose chapa grossa [79]. 
Tábela 31 - Velocidade de resfriamento, em função dos parâmetros de soldagem, para o tubo 1, quadrante 4.

\begin{tabular}{|c|c|c|c|c|c|c|c|c|}
\hline \multicolumn{9}{|c|}{ Tubo 1 - quadrante 4} \\
\hline & Camada & Camada & Camada & Camada & Camada & Camada & Camada & Camada \\
\hline & 1 & 2 & 3 & 4 & 5 & 6 & 7 & 8 \\
\hline $\mathrm{T}_{\text {pré }}\left({ }^{\circ} \mathrm{C}\right)$ & 181,7 & 173,7 & 173,7 & 161,7 & 182,7 & 167,7 & 157,0 & 165,7 \\
\hline $\begin{array}{c}\mathrm{T}_{\text {interpasse }} \\
\left({ }^{\circ} \mathrm{C}\right)\end{array}$ & 165,3 & 202,7 & 210,7 & 186,0 & 204,7 & 182,7 & 167,3 & 173,7 \\
\hline \multirow[t]{2}{*}{$\begin{array}{c}E_{\text {soldagem }} \\
(\mathrm{J} / \mathrm{cm})\end{array}$} & 2469,9 & 3757,2 & 2852,3 & 3233,4 & 3392,8 & 4078,4 & 3176,6 & 3457,0 \\
\hline & \multicolumn{8}{|c|}{ Velocidade de resfriamento* $\left({ }^{\circ} \mathrm{C} / \mathrm{s}\right)$} \\
\hline Temp. & Camada & Camada & Camada & Camada & Camada & Camada & Camada & Camada \\
\hline$\left({ }^{\circ} \mathrm{C}\right)$ & 1 & 2 & 3 & 4 & 5 & 6 & 7 & 8 \\
\hline 1200 & 263,66 & 166,26 & 215,50 & 164,12 & 183,37 & 159,37 & 173,15 & 191,35 \\
\hline 1000 & 170,27 & 106,26 & 137,18 & 105,77 & 117,08 & 102,87 & 112,57 & 124,04 \\
\hline 971 & 165,04 & 98,67 & 127,28 & 98,36 & 108,70 & 95,70 & 104,87 & 115,49 \\
\hline 900 & 131,20 & 81,28 & 104,62 & 81,37 & 89,49 & 79,23 & 87,16 & 95,84 \\
\hline 864 & 118,38 & 73,10 & 93,98 & 73,38 & 80,47 & 71,48 & 78,80 & 86,57 \\
\hline 809 & 100,06 & 61,45 & 78,82 & 61,95 & 67,60 & 60,41 & 66,85 & 73,33 \\
\hline 800 & 97,21 & 59,64 & 76,47 & 60,18 & 65,60 & 58,68 & 64,99 & 71,26 \\
\hline 740 & 79,26 & 48,26 & 61,69 & 48,99 & 53,05 & 47,83 & 53,25 & 58,26 \\
\hline 700 & 68,31 & 41,34 & 52,72 & 42,17 & 45,41 & 41,21 & 46,07 & 50,32 \\
\hline 670 & 60,63 & 36,50 & 46,45 & 37,39 & 40,08 & 36,57 & 41,03 & 44,75 \\
\hline 600 & 44,50 & 26,39 & 33,37 & 27,36 & 28,93 & 26,82 & 30,39 & 33,02 \\
\hline 500 & 25,77 & 14,78 & 18,43 & 15,74 & 16,14 & 15,51 & 17,97 & 19,35 \\
\hline 400 & 12,12 & 6,51 & 7,89 & 7,31 & 7,06 & 7,27 & 8,79 & 9,31 \\
\hline 300 & 3,56 & 1,58 & 1,76 & 2,07 & 1,68 & 2,12 & 2,86 & 2,90 \\
\hline
\end{tabular}

$\left({ }^{*}\right)$ A velocidade de resfriamento foi calculada no centro do cordão de solda, supondose chapa grossa [79]. 


\section{Tubo 1 - Quadrante 1}

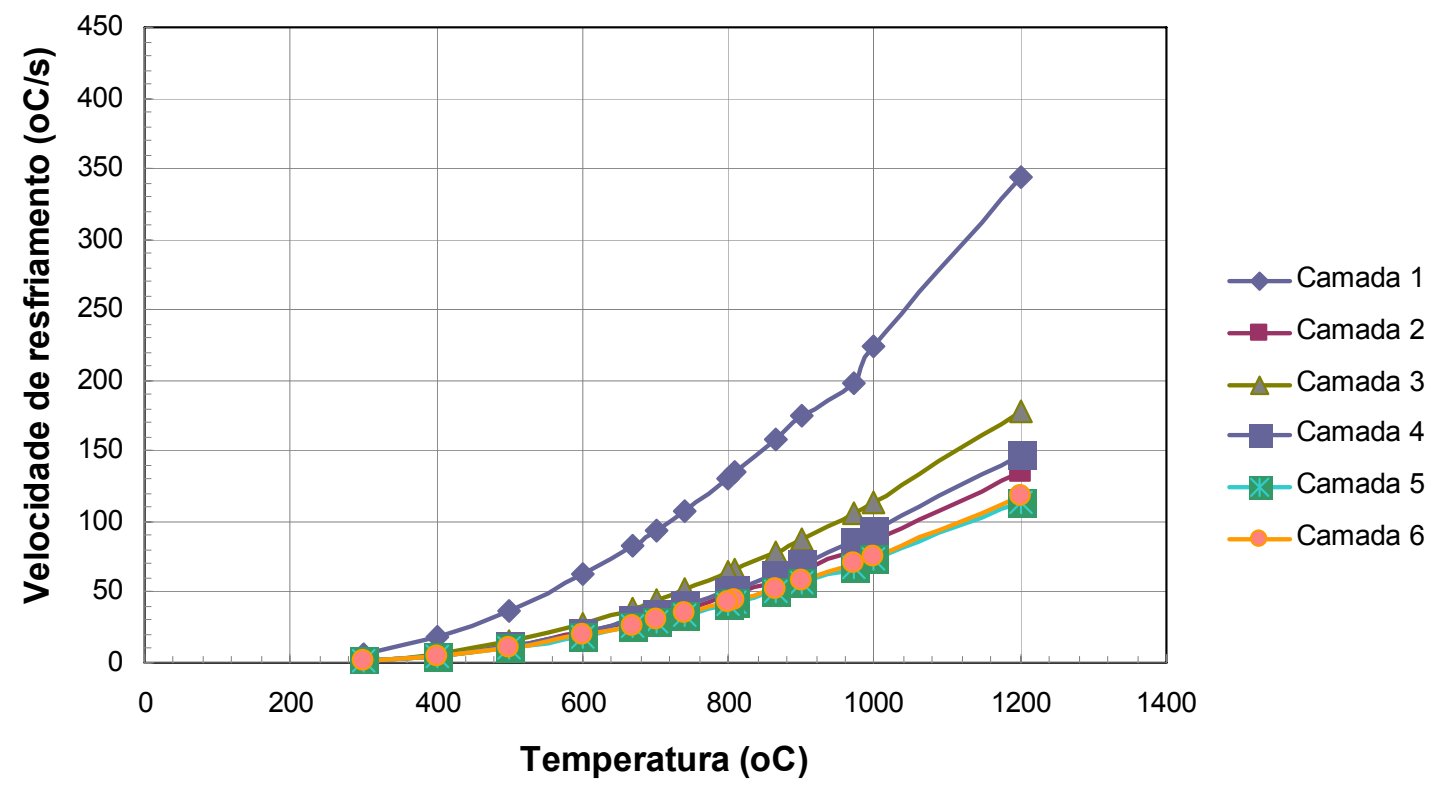

Figura 58 - Velocidade de resfriamento para diferentes temperaturas. Tubo 1 Quadrante 1:

Tubo 1 - Quadrante 2

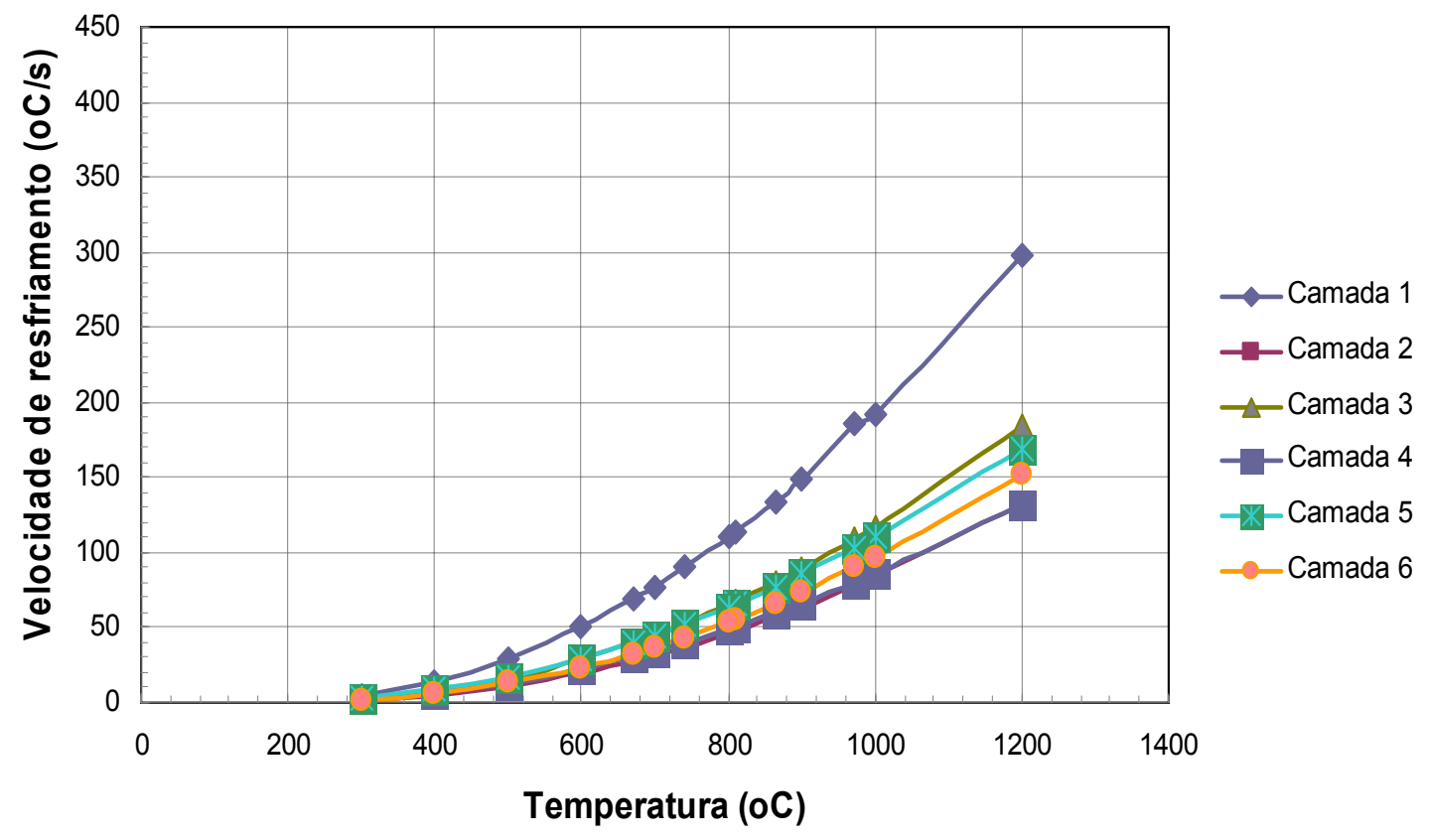

Figura 59 - Velocidade de resfriamento para diferentes temperaturas. Tubo 1 Quadrante 2: 


\section{Tubo 1 - Quadrante 3}

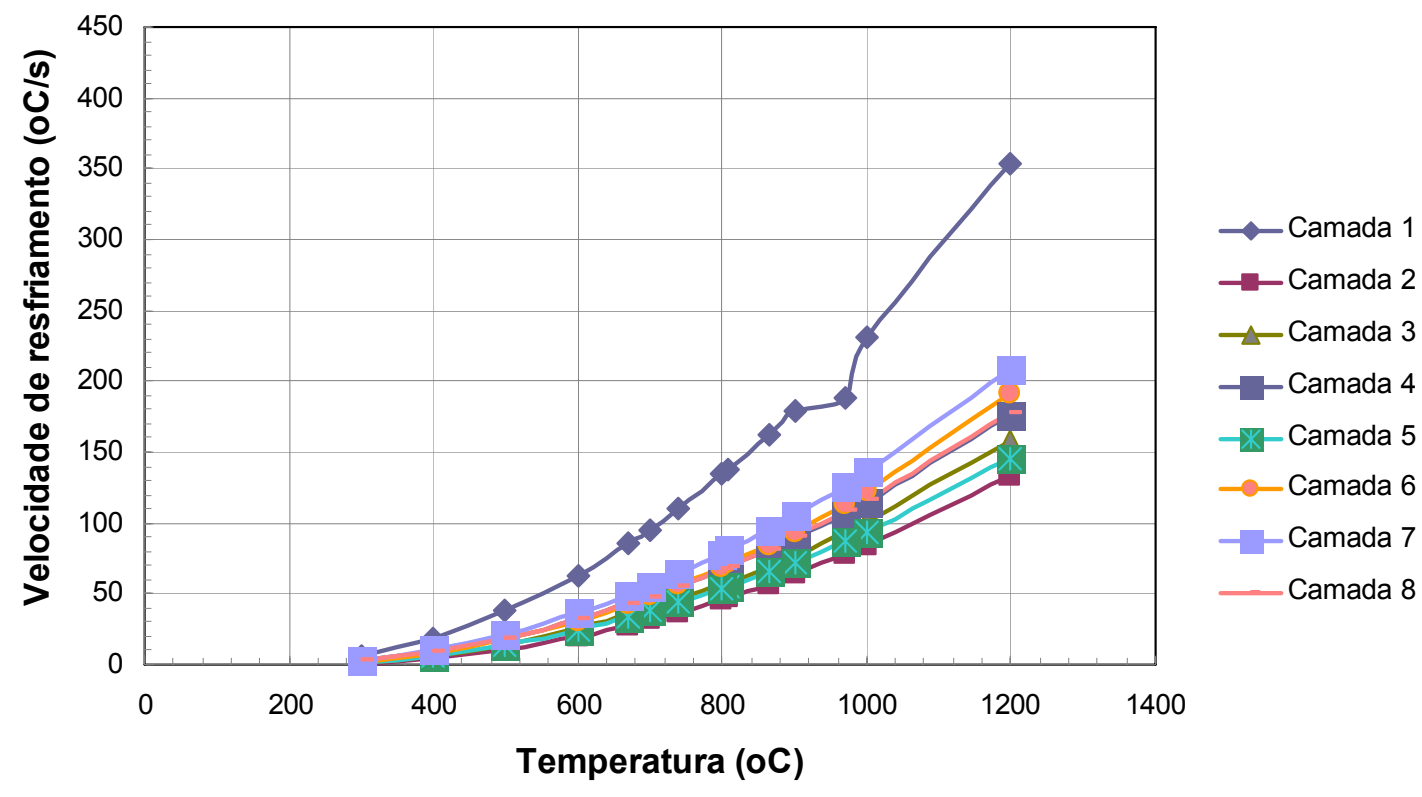

Figura 60 - Velocidade de resfriamento para diferentes temperaturas. Tubo 1 Quadrante 3:

Tubo 1 - Quadrante 4

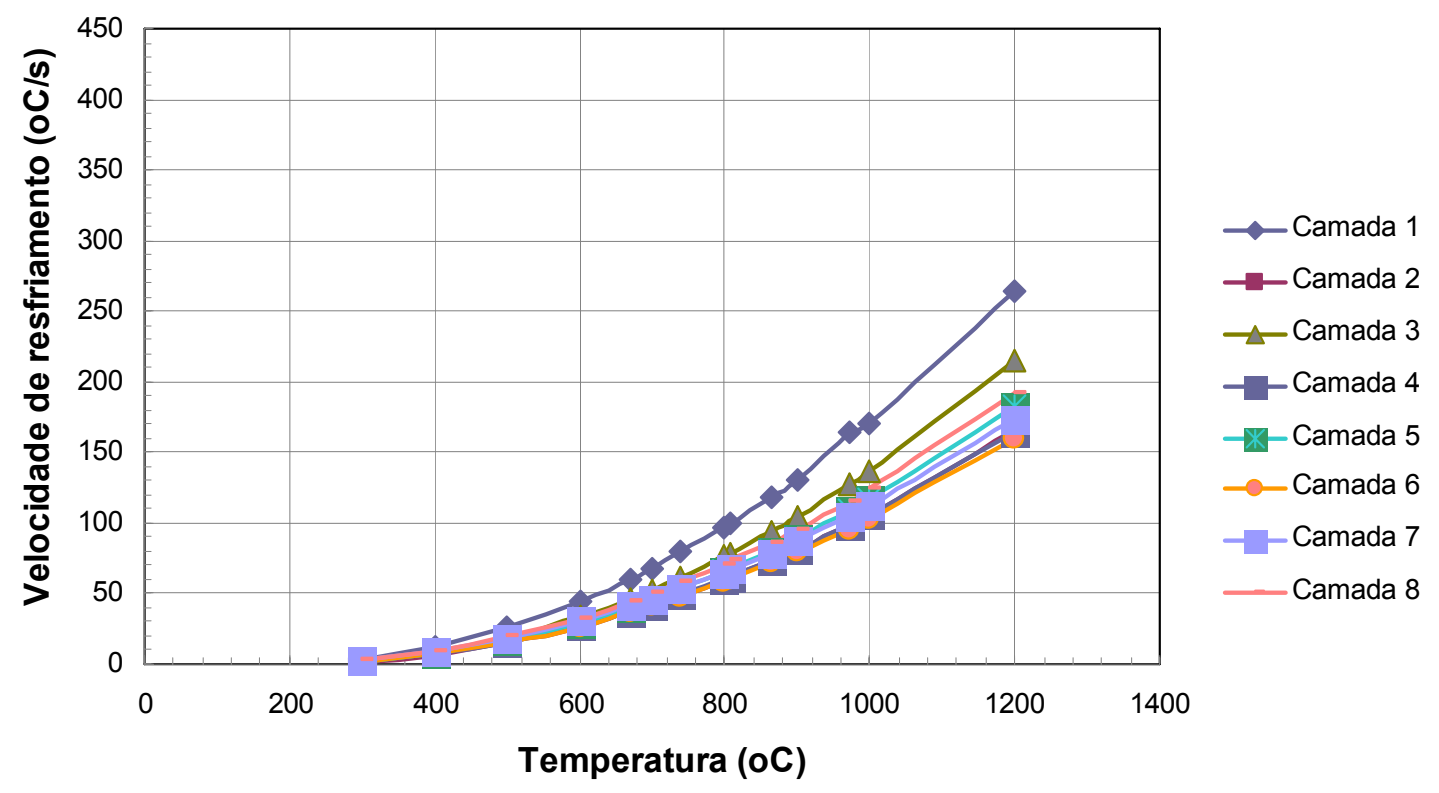

Figura 61 - Velocidade de resfriamento para diferentes temperaturas. Tubo 1 Quadrante 4: 
A partir da análise das figuras 58 a 61, observa-se que em todos os quadrantes e em todas as temperaturas, a velocidade de resfriamento da camada 1 é notadamente superior as demais camadas, situando-se entre $97,21{ }^{\circ} \mathrm{C} / \mathrm{s}$ no quadrante 4 a $134,15^{\circ} \mathrm{C} / \mathrm{s}$ no quadrante 3 e $25,7{ }^{\circ} \mathrm{C} / \mathrm{s}$ no quadrante 4 a $37,93{ }^{\circ} \mathrm{C} / \mathrm{s}$ no quadrante 3 , na faixa de temperatura compreendida entre 800 a $500{ }^{\circ} \mathrm{C}$, respectivamente.

No quadrante 4, diferentemente dos demais, observa-se que a velocidade de resfriamento da camada 1 é a mais baixa, aproximando-se das demais camadas no intervalo entre 800 e $500{ }^{\circ} \mathrm{C}$. Esta menor velocidade está relacionada com a combinação dos fatores Energia de soldagem e préaquecimento apresentados, maiores, em relação aos demais quadrantes.

Por outro lado, no quadrante 3 a velocidade de resfriamento no intervalo supracitado foi a maior de todos os quadrantes, seguido de muito perto pelo quadrante 1, também relacionado com a combinação dos fatores Energia de soldagem e pré-aquecimento apresentados, menores, em relação aos demais quadrantes.

Em relação às camadas de enchimento e acabamento, observa-se que todas mantiveram tendência de situarem-se próximas na faixa de 800 a $500^{\circ} \mathrm{C}$, sendo um pouco mais espaçadas no quadrante 3 . A camada 3 apresentou a tendência de possuir a maior velocidade de resfriamento em todos os quadrantes, a exceção do quadrante 3 , onde a camada 7 apresentou a maior velocidade. Já para a menor velocidade de resfriamento, não houve predomínio de determinada camada em nenhum quadrante.

Deste modo, observando-se somente a velocidade de resfriamento, nota-se que há maior tendência de formação de microestruturas frágeis no quadrante 3 , tanto no passe de raiz, quanto nos de enchimento e acabamento, devido a maior velocidade de resfriamento. Já para o quadrante 1 a tendência de formação de microestruturas frágeis é menor nos passes de enchimento e acabamento, pois as velocidades de resfriamento foram as mais baixas.

A partir dos dados da tabela 27 foram calculadas as velocidades de resfriamento as camadas de cada quadrante. As tabelas 32 a 35 apresentam as velocidades de resfriamento calculadas e as figuras de 62 a 65 apresentam graficamente as respectivas velocidades de resfriamento calculadas para diversas temperaturas. 
Tabela 32- Velocidade de resfriamento, em função dos parâmetros de soldagem, para o tubo 2, quadrante 1.

\begin{tabular}{|c|c|c|c|c|c|c|c|}
\hline \multicolumn{8}{|c|}{ Tubo 2- quadrante 1} \\
\hline & Camada & Camada & Camada & Camada & Camada & Camada & Camada \\
\hline & 1 & 2 & 3 & 4 & 5 & 6 & 7 \\
\hline $\mathrm{T}_{\text {pré }}\left({ }^{\circ} \mathrm{C}\right)$ & 152,0 & 174,0 & 171,7 & 111,0 & 155,7 & 161,7 & 166,7 \\
\hline $\begin{array}{c}\mathrm{T}_{\text {interpasse }} \\
\left({ }^{\circ} \mathrm{C}\right)\end{array}$ & 192,7 & 222,7 & 235,0 & 175,0 & 192,7 & 175,3 & 207,0 \\
\hline$E_{\text {soldagem }}$ & 2043,1 & 2790.6 & 4041.0 & 2659.4 & 3208.3 & 32433 & 24520 \\
\hline & \multirow{2}{*}{\multicolumn{7}{|c|}{ Velocidade de resfriamento* $\left({ }^{\circ} \mathrm{C} / \mathrm{s}\right)$}} \\
\hline & & & & & & & \\
\hline Temp. & Camada & Camada & Camada & Camada & Camada & Camada & Camada \\
\hline$\left({ }^{\circ} \mathrm{C}\right)$ & 1 & 2 & 3 & 4 & 5 & 6 & 7 \\
\hline 1200 & 337,59 & 214,95 & 144,72 & 248,10 & 198,62 & 203,30 & 252,55 \\
\hline 1000 & 221,03 & 135,98 & 90,95 & 160,72 & 127,58 & 131,68 & 161,06 \\
\hline 971 & 206,17 & 126,02 & 84,18 & 149,62 & 118,58 & 122,58 & 149,50 \\
\hline 900 & 171,97 & 103,24 & 68,72 & 124,12 & 97,93 & 101,68 & 123,00 \\
\hline 864 & 155,82 & 92,56 & 61,49 & 112,10 & 88,22 & 91,83 & 110,55 \\
\hline 809 & 132,68 & 77,37 & 51,20 & 94,92 & 74,36 & 77,75 & 92,82 \\
\hline 800 & 129,07 & 75,01 & 49,61 & 92,24 & 72,20 & 75,56 & 90,06 \\
\hline 740 & 106,27 & 60,23 & 39,63 & 75,38 & 58,64 & 61,74 & 72,76 \\
\hline 700 & 92,30 & 51,27 & 33,60 & 65,09 & 50,38 & 53,30 & 62,25 \\
\hline 670 & 82,47 & 45,03 & 29,41 & 57,86 & 44,60 & 47,38 & 54,90 \\
\hline 600 & 61,69 & 32,04 & 20,70 & 42,65 & 32,48 & 34,92 & 39,56 \\
\hline 500 & 37,22 & 17,31 & 10,91 & 24,94 & 18,49 & 20,41 & 21,99 \\
\hline 400 & 18,90 & 7,08 & 4,23 & 11,95 & 8,41 & 9,77 & 9,54 \\
\hline 300 & 6,73 & 1,35 & 0,66 & 3,69 & 2,26 & 3,01 & 2,22 \\
\hline
\end{tabular}

$\left(^{*}\right)$ A velocidade de resfriamento foi calculada no centro do cordão de solda, supondose chapa grossa [79]. 
Tabela 33- Velocidade de resfriamento, em função dos parâmetros de soldagem, para o tubo 2, quadrante 2.

\begin{tabular}{|c|c|c|c|c|c|c|c|}
\hline \multicolumn{8}{|c|}{ Tubo 2- quadrante 2} \\
\hline & Camada & Camada & Camada & Camada & Camada & Camada & Camada \\
\hline & 1 & 2 & 3 & 4 & 5 & 6 & 7 \\
\hline $\mathrm{T}_{\text {pré }}\left({ }^{\circ} \mathrm{C}\right)$ & 175,0 & 167,7 & 178,7 & 157,7 & 166,3 & 167,0 & 164,7 \\
\hline $\begin{array}{c}\mathrm{T}_{\text {interpasse }} \\
\left({ }^{\circ} \mathrm{C}\right)\end{array}$ & 124,3 & 233,3 & 224,7 & 205,7 & 183,0 & 201,3 & 201,7 \\
\hline $\begin{array}{c}\mathrm{E}_{\text {soldagem }} \\
(\mathrm{J} / \mathrm{cm})\end{array}$ & 2300,5 & 3191,7 & 4094,8 & 2937,7 & 3079,9 & 3946,1 & 2895,9 \\
\hline & \multicolumn{7}{|c|}{ Velocidade de resfriamento* $\left({ }^{\circ} \mathrm{C} / \mathrm{s}\right)$} \\
\hline Temp. & Camada & Camada & Camada & Camada & Camada & Camada & Camada \\
\hline$\left({ }^{\circ} \mathrm{C}\right)$ & 1 & 2 & 3 & 4 & 5 & 6 & 7 \\
\hline 1200 & 286,80 & 183,86 & 145,89 & 211,36 & 210,89 & 158,72 & 216,14 \\
\hline 1000 & 185,80 & 115,65 & 92,20 & 134,88 & 136,10 & 101,51 & 138,21 \\
\hline 971 & 172,97 & 107,07 & 85,43 & 125,22 & 126,61 & 94,27 & 128,35 \\
\hline 900 & 143,49 & 87,45 & 69,95 & 103,06 & 104,82 & 77,68 & 105,76 \\
\hline 864 & 129,59 & 78,26 & 62,69 & 92,65 & 94,56 & 69,88 & 95,13 \\
\hline 809 & 109,73 & 65,21 & 52,37 & 77,82 & 79,90 & 58,77 & 79,99 \\
\hline 800 & 106,63 & 63,18 & 50,77 & 75,51 & 77,62 & 57,04 & 77,64 \\
\hline 740 & 87,14 & 50,51 & 40,73 & 61,04 & 63,26 & 46,18 & 62,85 \\
\hline 700 & 75,24 & 42,85 & 34,65 & 52,24 & 54,50 & 39,57 & 53,85 \\
\hline 670 & 66,89 & 37,52 & 30,42 & 46,09 & 48,36 & 34,96 & 47,57 \\
\hline 600 & 49,31 & 26,45 & 21,61 & 33,24 & 35,46 & 25,29 & 34,41 \\
\hline 500 & 28,83 & 13,99 & 11,63 & 18,52 & 20,49 & 14,20 & 19,30 \\
\hline 400 & 13,82 & 5,47 & 4,71 & 8,07 & 9,60 & 6,28 & 8,53 \\
\hline 300 & 4,27 & 0,87 & 0,87 & 1,90 & 2,79 & 1,55 & 2,10 \\
\hline
\end{tabular}

$\left({ }^{*}\right)$ A velocidade de resfriamento foi calculada no centro do cordão de solda, supondose chapa grossa [79]. 
Tabela 34- Velocidade de resfriamento, em função dos parâmetros de soldagem, para o tubo 2, quadrante 3.

\begin{tabular}{|c|c|c|c|c|c|c|c|}
\hline \multicolumn{7}{|c|}{ Tubo 2- quadrante 3 } \\
\hline & $\begin{array}{c}\text { Camada } \\
1\end{array}$ & $\begin{array}{c}\text { Camada } \\
\text { Camada }\end{array}$ & $\begin{array}{c}\text { Camada } \\
3\end{array}$ & 4 & Camada & Camada & Camada \\
\hline $\left.\mathrm{T}_{\text {pré }}{ }^{\circ} \mathrm{C}\right)$ & 199,0 & 165,3 & 155,7 & 181,0 & 164,7 & 163,7 & 160,0 \\
\hline $\begin{array}{c}\mathrm{T}_{\text {interpasse }} \\
\left({ }^{\circ} \mathrm{C}\right)\end{array}$ & 202,3 & 194,7 & 163,0 & 215,0 & 211,3 & 217,3 & 181,0 \\
\hline $\begin{array}{c}\mathrm{E}_{\text {soldagem }} \\
(\mathrm{J} / \mathrm{cm})\end{array}$ & 1644,2 & 2494,3 & 2392,5 & 3023,3 & 3055,9 & 3017,8 & 3647,3 \\
\hline & & & & & & & \\
\hline Temp. & Camada & Camada & Camada & Camada & Camada & Camada & Camada \\
\hline$\left.{ }^{\circ} \mathrm{C}\right)$ & 1 & 2 & 3 & 4 & 5 & 6 & 7 \\
\hline 1200 & 382,71 & 254,47 & 282,27 & 201,53 & 200,87 & 200,95 & 178,79 \\
\hline 1000 & 245,06 & 163,29 & 183,89 & 128,00 & 127,82 & 127,47 & 115,49 \\
\hline 971 & 227,63 & 151,74 & 171,37 & 118,72 & 118,60 & 118,20 & 107,46 \\
\hline 900 & 187,69 & 125,26 & 142,57 & 97,47 & 97,46 & 96,98 & 89,01 \\
\hline 864 & 168,91 & 112,80 & 128,99 & 87,49 & 87,54 & 87,02 & 80,32 \\
\hline 809 & 142,12 & 95,02 & 109,54 & 73,29 & 73,41 & 72,85 & 67,91 \\
\hline 800 & 137,96 & 92,26 & 106,51 & 71,09 & 71,21 & 70,65 & 65,97 \\
\hline 740 & 111,79 & 74,87 & 87,39 & 57,25 & 57,44 & 56,85 & 53,80 \\
\hline 700 & 95,87 & 64,29 & 75,69 & 48,86 & 49,07 & 48,48 & 46,38 \\
\hline 670 & 84,73 & 56,89 & 67,47 & 43,00 & 43,23 & 42,64 & 41,17 \\
\hline 600 & 61,42 & 41,37 & 50,13 & 30,79 & 31,04 & 30,47 & 30,23 \\
\hline 500 & 34,60 & 23,47 & 29,81 & 16,87 & 17,12 & 16,63 & 17,52 \\
\hline 400 & 15,43 & 10,62 & 14,74 & 7,11 & 7,31 & 6,94 & 8,26 \\
\hline 300 & 3,90 & 2,79 & 4,93 & 1,50 & 1,62 & 1,42 & 2,44 \\
\hline
\end{tabular}

$\left(^{*}\right)$ A velocidade de resfriamento foi calculada no centro do cordão de solda, supondose chapa grossa [79]. 
Tábela 35 - Velocidade de resfriamento, em função dos parâmetros de soldagem, para o tubo 2, quadrante 4.

\begin{tabular}{|c|c|c|c|c|c|c|c|}
\hline \multicolumn{8}{|c|}{ Tubo 2- quadrante 4} \\
\hline & $\begin{array}{c}\text { Camada } \\
1\end{array}$ & $\begin{array}{c}\text { Camada } \\
2\end{array}$ & $\begin{array}{c}\text { Camada } \\
3\end{array}$ & $\begin{array}{c}\text { Camada } \\
4\end{array}$ & $\begin{array}{c}\text { Camada } \\
5\end{array}$ & $\begin{array}{c}\text { Camada } \\
6\end{array}$ & $\begin{array}{c}\text { Camada } \\
7\end{array}$ \\
\hline $\mathrm{T}_{\text {pré }}\left({ }^{\circ} \mathrm{C}\right)$ & 175,0 & 167,7 & 178,7 & 157,7 & 166,3 & 167,0 & 164,7 \\
\hline $\begin{array}{c}\mathrm{T}_{\text {interpasse }} \\
\left({ }^{\circ} \mathrm{C}\right)\end{array}$ & 165,3 & 228,3 & 242,0 & 189,0 & 174,3 & 209,3 & 184,0 \\
\hline $\begin{array}{c}E_{\text {soldagem }} \\
(\mathrm{J} / \mathrm{cm})\end{array}$ & 2483,3 & 2530,7 & 4136,2 & 3147,3 & 2716,5 & 3338,0 & 3246,4 \\
\hline & \multicolumn{7}{|c|}{ Velocidade de resfriamento* $\left({ }^{\circ} \mathrm{C} / \mathrm{s}\right)$} \\
\hline $\begin{array}{l}\text { Temp. } \\
\left({ }^{\circ} \mathrm{C}\right)\end{array}$ & $\begin{array}{c}\text { Camada } \\
1\end{array}$ & $\begin{array}{c}\text { Camada } \\
2\end{array}$ & $\begin{array}{c}\text { Camada } \\
3\end{array}$ & $\begin{array}{c}\text { Camada } \\
4\end{array}$ & $\begin{array}{c}\text { Camada } \\
5\end{array}$ & $\begin{array}{c}\text { Camada } \\
6\end{array}$ & $\begin{array}{c}\text { Camada } \\
7\end{array}$ \\
\hline 1200 & 270,03 & 234,29 & 139,34 & 203,95 & 243,20 & 184,64 & 199,69 \\
\hline 1000 & 175,62 & 147,77 & 87,24 & 131,24 & 157,60 & 117,61 & 128,81 \\
\hline 971 & 163,61 & 136,87 & 80,69 & 122,02 & 146,73 & 109,14 & 119,82 \\
\hline 900 & 136,00 & 111,95 & 65,74 & 100,87 & 121,74 & 89,74 & 99,17 \\
\hline 864 & 122,97 & 100,27 & 58,74 & 90,91 & 109,96 & 80,63 & 89,45 \\
\hline 809 & 104,34 & 83,67 & 48,81 & 76,70 & 93,12 & 67,65 & 75,57 \\
\hline 800 & 101,44 & 81,10 & 47,27 & 74,49 & 90,50 & 65,64 & 73,40 \\
\hline 740 & 83,13 & 64,97 & 37,65 & 60,58 & 73,97 & 52,98 & 59,80 \\
\hline 700 & 71,93 & 55,21 & 31,85 & 52,10 & 63,88 & 45,29 & 51,51 \\
\hline 670 & 64,07 & 48,41 & 27,81 & 46,16 & 56,80 & 39,93 & 45,69 \\
\hline 600 & 47,49 & 34,28 & 19,46 & 33,71 & 41,89 & 28,71 & 33,48 \\
\hline 500 & 28,10 & 18,31 & 10,11 & 19,30 & 24,52 & 15,90 & 19,32 \\
\hline 400 & 13,77 & 7,31 & 3,79 & 8,88 & 11,77 & 6,84 & 9,03 \\
\hline 300 & 4,50 & 1,27 & 0,51 & 2,46 & 3,65 & 1,55 & 2,60 \\
\hline
\end{tabular}

$\left(^{*}\right)$ A velocidade de resfriamento foi calculada no centro do cordão de solda, supondose chapa grossa [79]. 


\section{Tubo 2 - Quadrante 1}

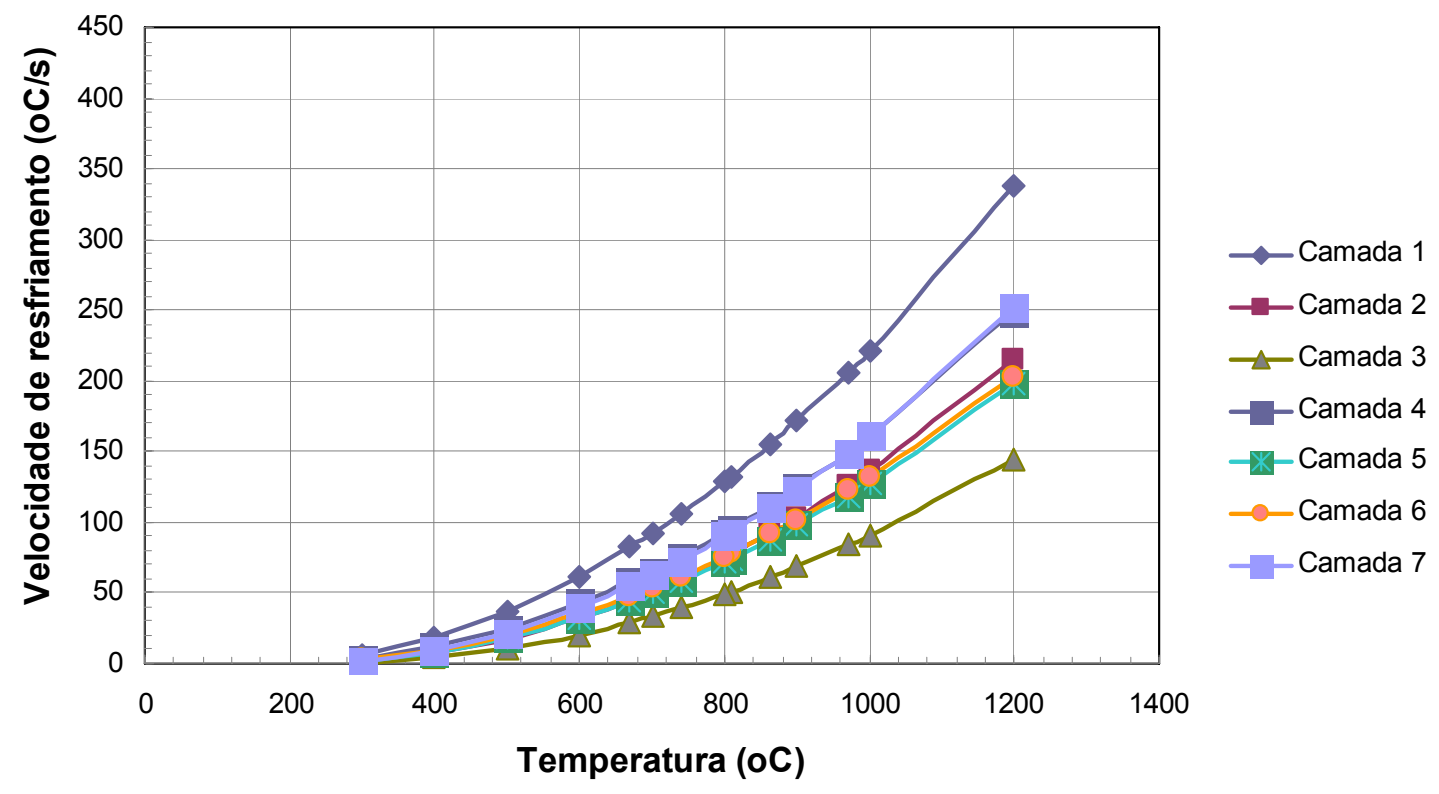

Figura 62 - Velocidade de resfriamento para diferentes temperaturas. Tubo 2 Quadrante 1:

\section{Tubo 2 - Quadrante 2}

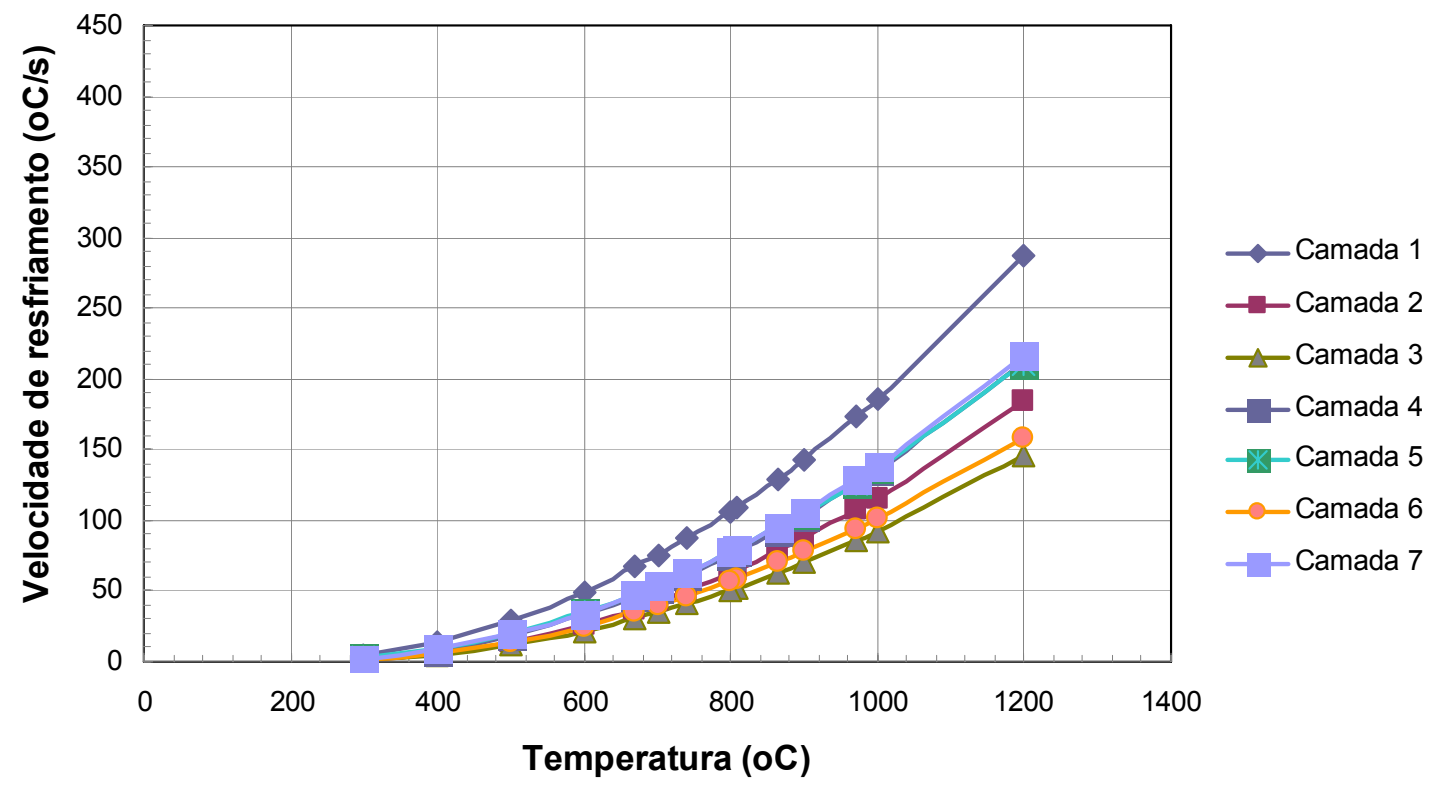

Figura 63 - Velocidade de resfriamento para diferentes temperaturas. Tubo 2 Quadrante 2: 


\section{Tubo 2 - Quadrante 3}

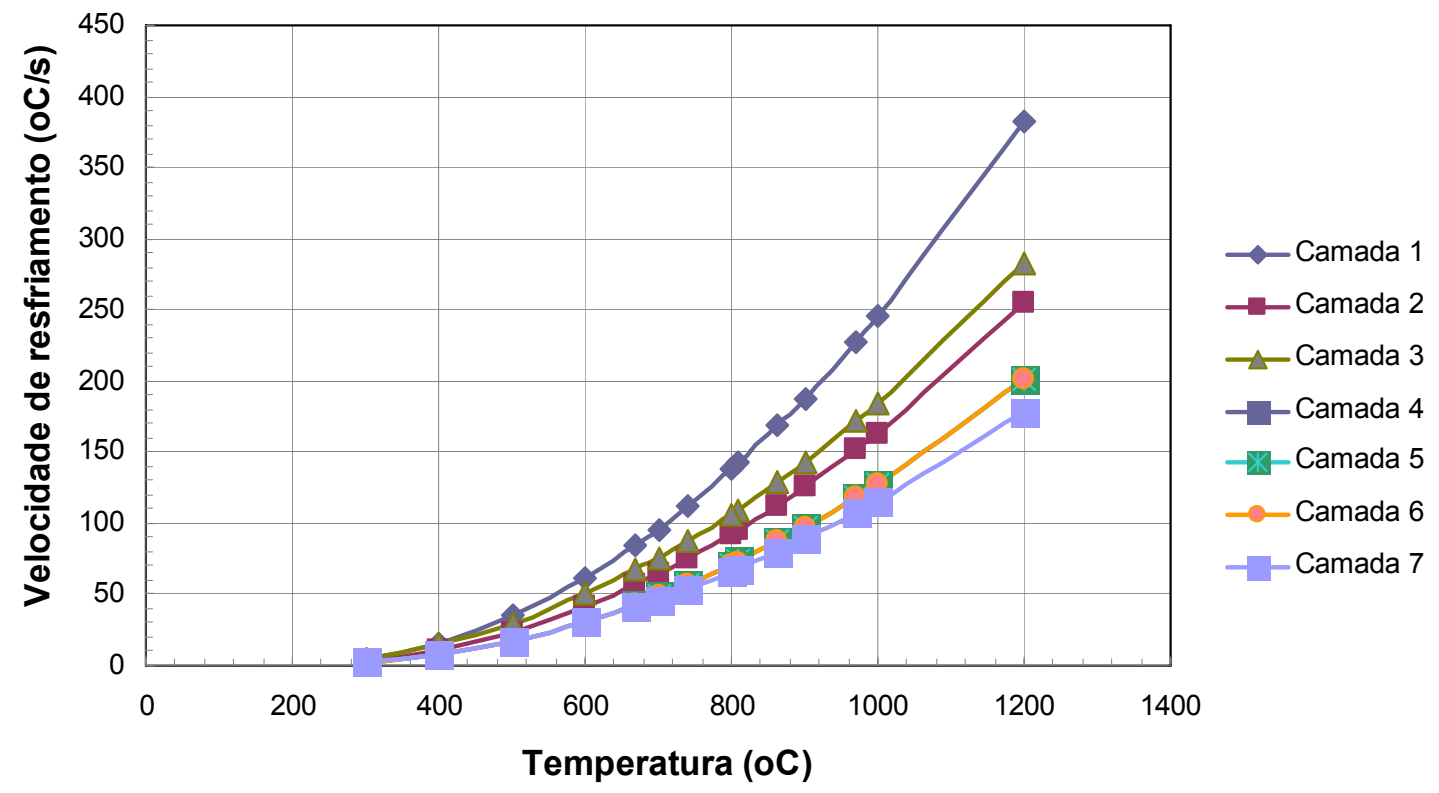

Figura 64 - Velocidade de resfriamento para diferentes temperaturas. Tubo 2 Quadrante 3:

Tubo 2 - Quadrante 4

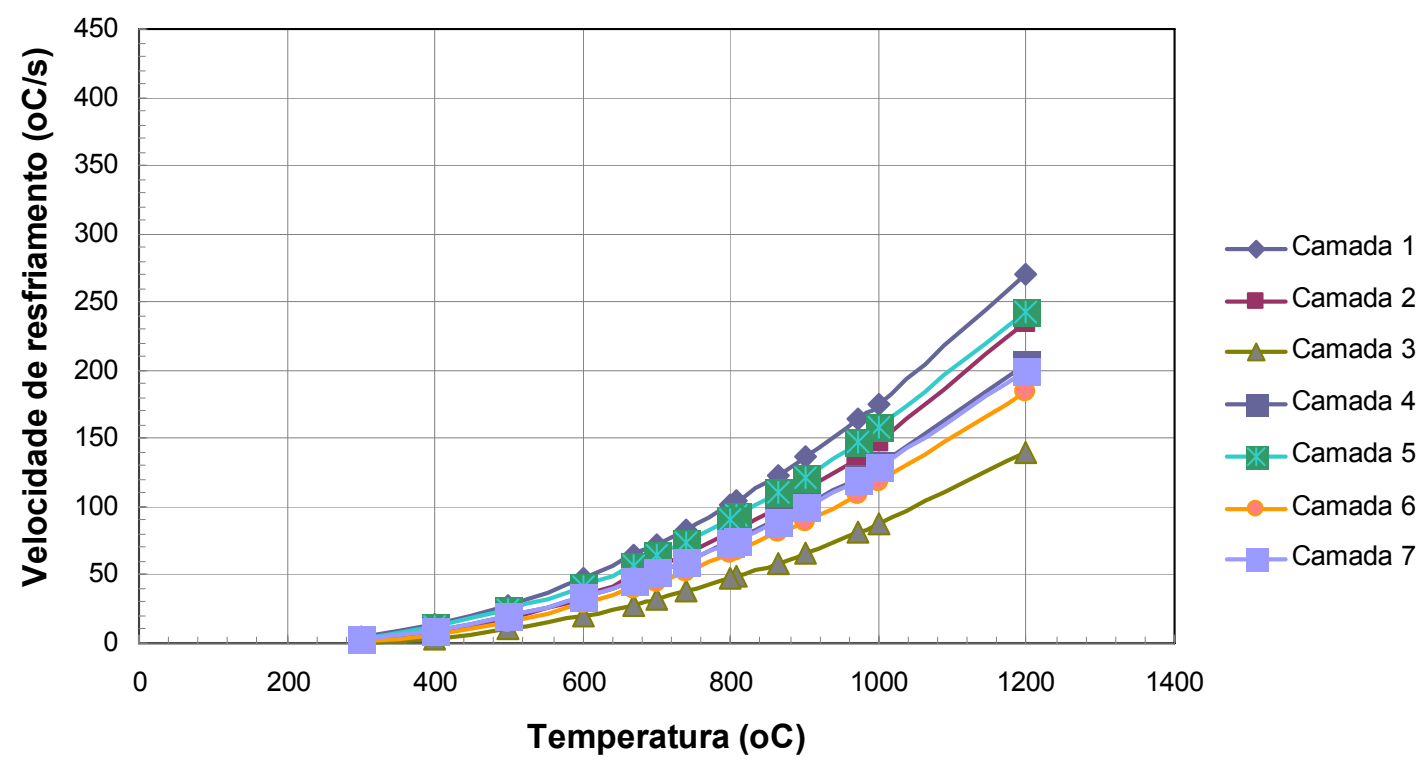

Figura 65 - Velocidade de resfriamento para diferentes temperaturas. Tubo 2 Quadrante 4: 
A partir da análise das figuras 62 a 65 , observa-se que em todos os quadrantes e em todas as temperaturas, a velocidade de resfriamento da camada 1 também é superior as demais camadas, exceto o quadrante 4 , onde apresentou-se ligeiramente acima das demais camadas. A velocidade de resfriamento situa-se entre $101,44{ }^{\circ} \mathrm{C} / \mathrm{s}$ no quadrante 4 a $137,96{ }^{\circ} \mathrm{C} / \mathrm{s}$ no quadrante 3 e $28,10^{\circ} \mathrm{C} / \mathrm{s}$ no quadrante 4 a $37,22^{\circ} \mathrm{C} / \mathrm{s}$ no quadrante 1 , na faixa de temperatura compreendida entre 800 a $500{ }^{\circ} \mathrm{C}$, respectivamente.

No quadrante 4, diferentemente dos demais, observa-se que a velocidade de resfriamento da camada 1 é a mais baixa, sendo praticamente idêntica das demais camadas no intervalo entre 800 e $500{ }^{\circ} \mathrm{C}$. Esta menor velocidade está relacionada com a combinação dos fatores Energia de soldagem e pré-aquecimento apresentados. A Energia de soldagem foi maior do que a dos demais quadrantes, enquanto que o pré-aquecimento foi um pouco menor. Neste caso deve-se a menor velocidade encontrada deve-se em maior parte a Energia de soldagem.

Por outro lado, no quadrante 3 a velocidade de resfriamento na temperatura de $800^{\circ} \mathrm{C}$ foi maior que todos os quadrantes, seguido de perto pelo quadrante 1. Na temperatura de $500{ }^{\circ} \mathrm{C}$ inverte-se os quadrantes, com o quadrante 1 apresentando maior velocidade em relação ao quadrante 3. A maior velocidade apresentada por estes quadrantes reflete a combinação dos fatores Energia de soldagem e pré-aquecimento apresentados, onde a Energia de soldagem foi maior no quadrante 1 e o pré-aquecimento foi maior no quadrante 3 .

Em relação às camadas de enchimento e acabamento, observa-se que todas mantiveram tendência de situarem-se próximas na faixa de 800 a $500^{\circ} \mathrm{C}$, embora mais espaçadas (menos uniforme) em relação ao tubo 1 (mais uniforme), e tendendo a ser mais próximas no quadrante 2 . Ao contrário do tubo 1, a camada 3 apresentou a tendência de possuir a menor velocidade de resfriamento em todos os quadrantes, a exceção do quadrante 3 , onde a camada 7 apresentou a menor velocidade. Já para a maior velocidade de resfriamento, há o predomínio da camada 7 nos quadrantes 1 e 2 .

Deste modo, observando-se somente a velocidade de resfriamento, nota-se que há maior tendência de formação de microestruturas frágeis nos quadrantes 1 e 3 , tanto no passe de raiz, quanto nos de enchimento e 
acabamento, devido a maior velocidade de resfriamento. Já para o quadrante 2 a tendência de formação de microestruturas frágeis é menor nos passes de enchimento e acabamento, pois as velocidades de resfriamento foram as mais baixas.

Através da análise em conjunto das figuras 58 a 65 pode-se notar que a camada 1 apresentou a maior velocidade de resfriamento em todos os quadrantes.

Em relação às demais camadas, observa-se que o tubo 1 apresentou maior uniformidade nas velocidades de resfriamento entre todas as camadas em relação ao tubo 2, já que este apresentou-se menos uniforme. A uniformidade menor das velocidades de resfriamento pode resultar em maior dispersão no valor das durezas das camadas, dependendo da composição química.

Uma possível solução para diminuir a velocidade de resfriamento da camada 1 é o emprego de uma maior temperatura de pré-aquecimento, em relação às demais camadas, já que este diminui a velocidade de resfriamento.

\subsection{Caracterização metalográfica:}

\subsubsection{Macrografia:}

As figuras 66 e 67 apresentam as macrografias das juntas soldadas nas posições indicadas pela figura 35.

Analisando-se as figuras 66 e 67 nota-se o contorno dos diversos passes, com suas respectivas ZACs.

A ZAC na raiz foi muito maior que a ZAC nas demais camadas. Esta diferença na extensão da ZAC na raiz foi causada pela energia de soldagem produzida pela segunda camada. 
(a)

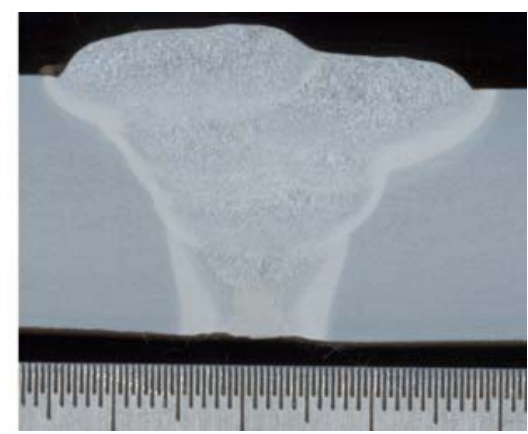

(c)

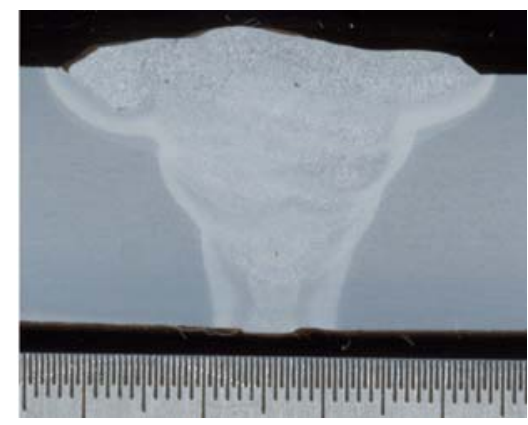

(b)

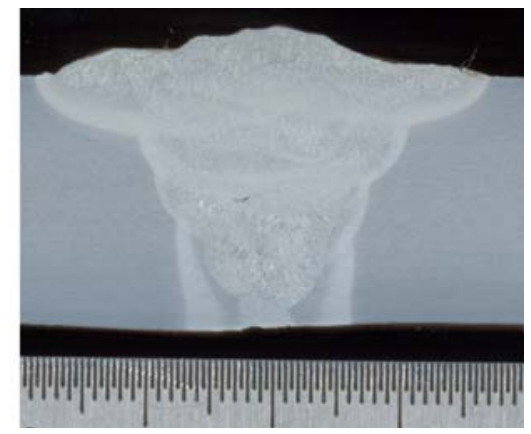

(d)

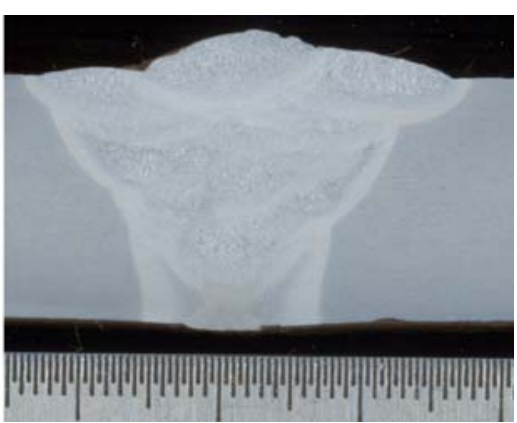

Figura 66- Macrografia das soldas do tubo 1 nas posições indicadas pela figura 34.(a) posição plana;(b) posição vertical direita; (c) posição vertical esquerda: (d) posição sobre-cabeça.

(a)

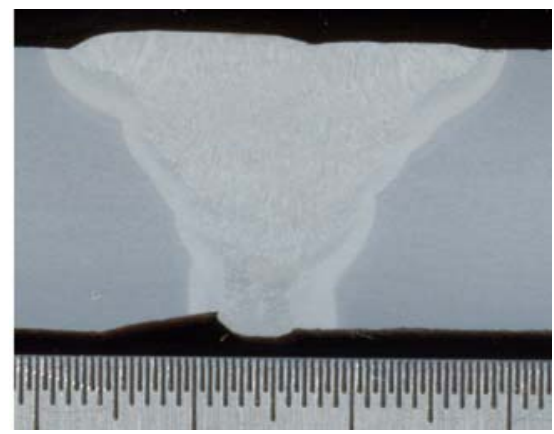

(b)

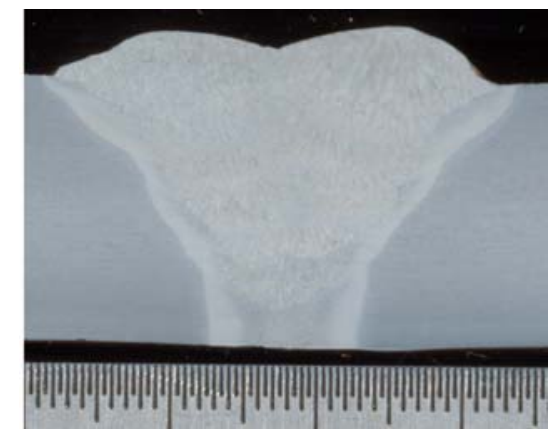

(d)

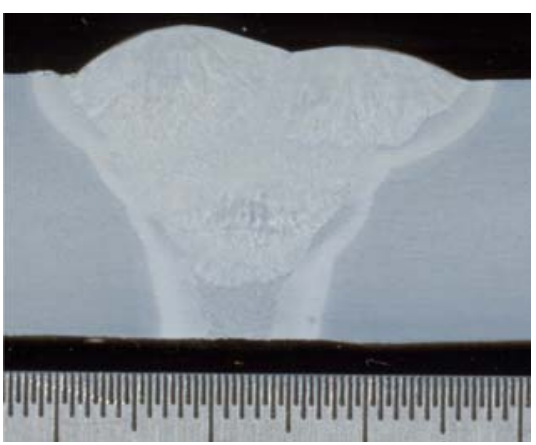

Figura 67- Macrografia das soldas do tubo 2 nas posições indicadas pela figura 34. .(a) posição plana;(b) posição vertical direita; (c) posição vertical esquerda: (d) posição sobre-cabeça. 


\subsubsection{Extensão da ZAC:}

A extensão da ZAC foi medida para todas as soldas das figuras 66 e 67, conforme o exemplo da figura 68 e apresentados na tabela 36 para o tubo $1 \mathrm{e}$ 37 para o tubo 2. Na tabela a letra 'E' significa lado esquerdo do corpo-deprova e a letra " $D$ " lado direito do corpo-de-prova. Com relação às posições de soldagem, as siglas VE significa vertical esquerda, VD vertical direita e SC sobre-cabeça. As figuras 6869 e 70 apresentam a extensão da ZAC, segundo os dados das respectivas tabelas do tubo 1 e 2 .

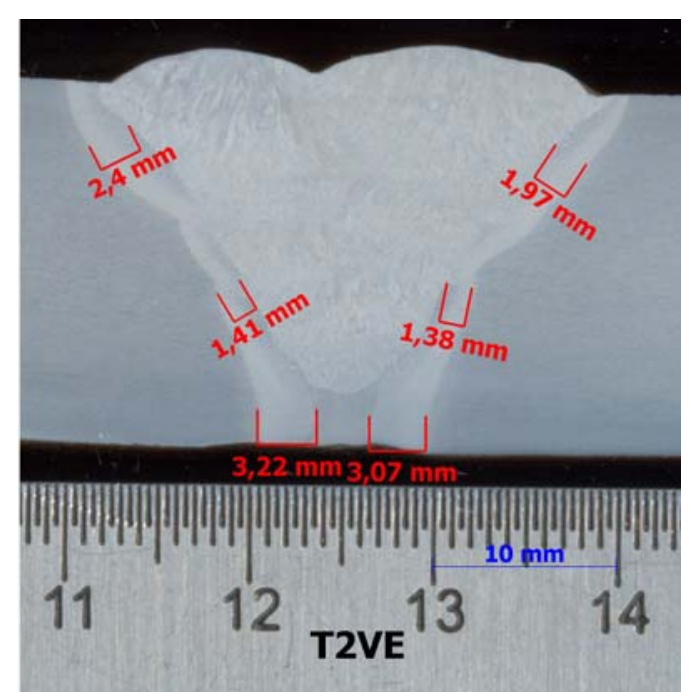

Figura 68- Exemplo de medida da extensão da ZAC.

Tabela 36- Extensão da ZAC de acordo com a posição de soldagem para o tubo 1.

\begin{tabular}{|c|c|c|c|c|c|c|c|c|}
\hline & \multicolumn{2}{|c|}{ Plana } & \multicolumn{2}{c|}{ VE } & \multicolumn{2}{c|}{ VD } & \multicolumn{2}{c|}{ SC } \\
\hline & $\mathrm{E}$ & $\mathrm{D}$ & $\mathrm{E}$ & $\mathrm{D}$ & $\mathrm{E}$ & $\mathrm{D}$ & $\mathrm{E}$ & $\mathrm{D}$ \\
\hline Acabamento & 0,94 & 1,68 & 2,52 & 1,32 & 1,65 & 1,35 & 1,20 & 1,30 \\
\hline Enchimento & 1,40 & 0,97 & 1,41 & 1,23 & 1,00 & 0,65 & 1,10 & 1,50 \\
\hline Raiz & 3,64 & 3,58 & 3,71 & 3,28 & 4,36 & 4,43 & 4,20 & 4,80 \\
\hline
\end{tabular}

Tábela 37- Extensão da ZAC de acordo com a posição de soldagem para o tubo 2.

\begin{tabular}{|c|c|c|c|c|c|c|c|c|}
\hline & \multicolumn{2}{|c|}{ Plana } & \multicolumn{2}{c|}{ VE } & \multicolumn{2}{c|}{ VD } & \multicolumn{2}{c|}{ SC } \\
\hline & $\mathrm{E}$ & $\mathrm{D}$ & $\mathrm{E}$ & $\mathrm{D}$ & $\mathrm{E}$ & $\mathrm{D}$ & $\mathrm{E}$ & $\mathrm{D}$ \\
\hline Acabamento & 3,65 & 2,27 & 2,4 & 1,97 & 2,55 & 2,36 & 2,26 & 2,1 \\
\hline Enchimento & 1,61 & 0,94 & 1,41 & 1,38 & 1,44 & 1,11 & 1,75 & 2,01 \\
\hline Raiz & 2,29 & 3,07 & 3,22 & 3,07 & 3,86 & 2,97 & 2,94 & 3,07 \\
\hline
\end{tabular}


A extensão da ZAC é função da temperatura da chapa, da energia de soldagem, da espessura da chapa, da geometria do chanfro e das constantes físicas do material.

Pela análise da figura 69, nota-se que o passe de raiz apresentou a maior extensão da ZAC em relação aos passes de enchimento e acabamento. Esta maior extensão foi devido ao reaquecimento e formação de nova ZAC decorrente do primeiro passe de enchimento. Os passes de acabamento apresentaram, de modo geral, extensão da ZAC maior que a dos passes de enchimento, devido às condições de transferência de calor diferenciadas entre ambos.

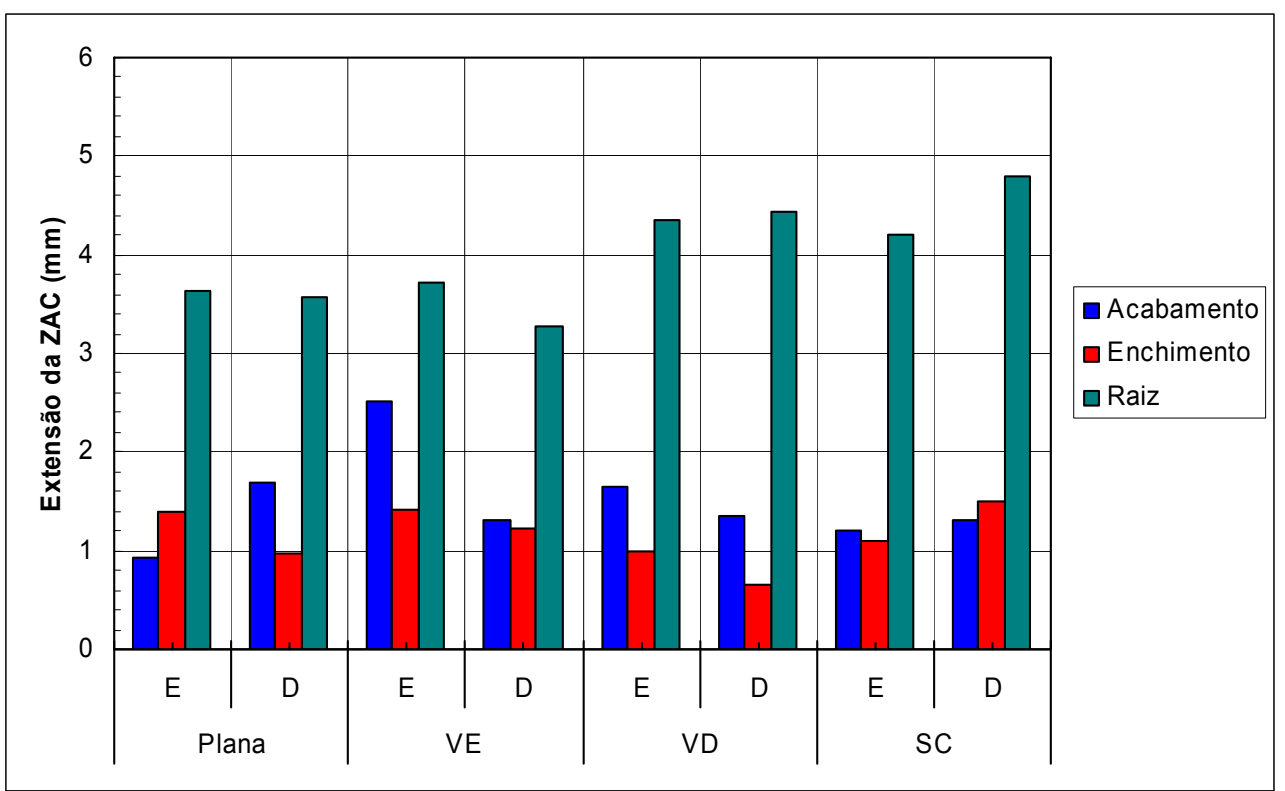

Figura 69 - Extensão da ZAC para o tubo 1, de acordo com os dados da tabela 35.

Pela análise da figura 70, observa-se que em comparação com o tubo 1, a extensão da ZAC da raiz do tubo 2 manteve-se relativamente próxima, também sendo afetada pela ZAC do primeiro passe de enchimento.

Analisando-se as tabelas 26 e 27 nota-se que a camada no. 2, realizada logo em seguida ao passe de raiz, apresenta uma energia de soldagem muito maior. Isto significa que esta energia de soldagem ocasionou uma maior extensão da ZAC na raiz.

Os passes de acabamento tendem a apresentar um tamanho da ZAC maior que os passes de enchimento, para ambos os tubos. A tendência é mais 
acentuada para o tubo 2. Isto pode ser devido as diferenças das energias de soldagem e as temperaturas de interpasse, como mostra a tabela 27.

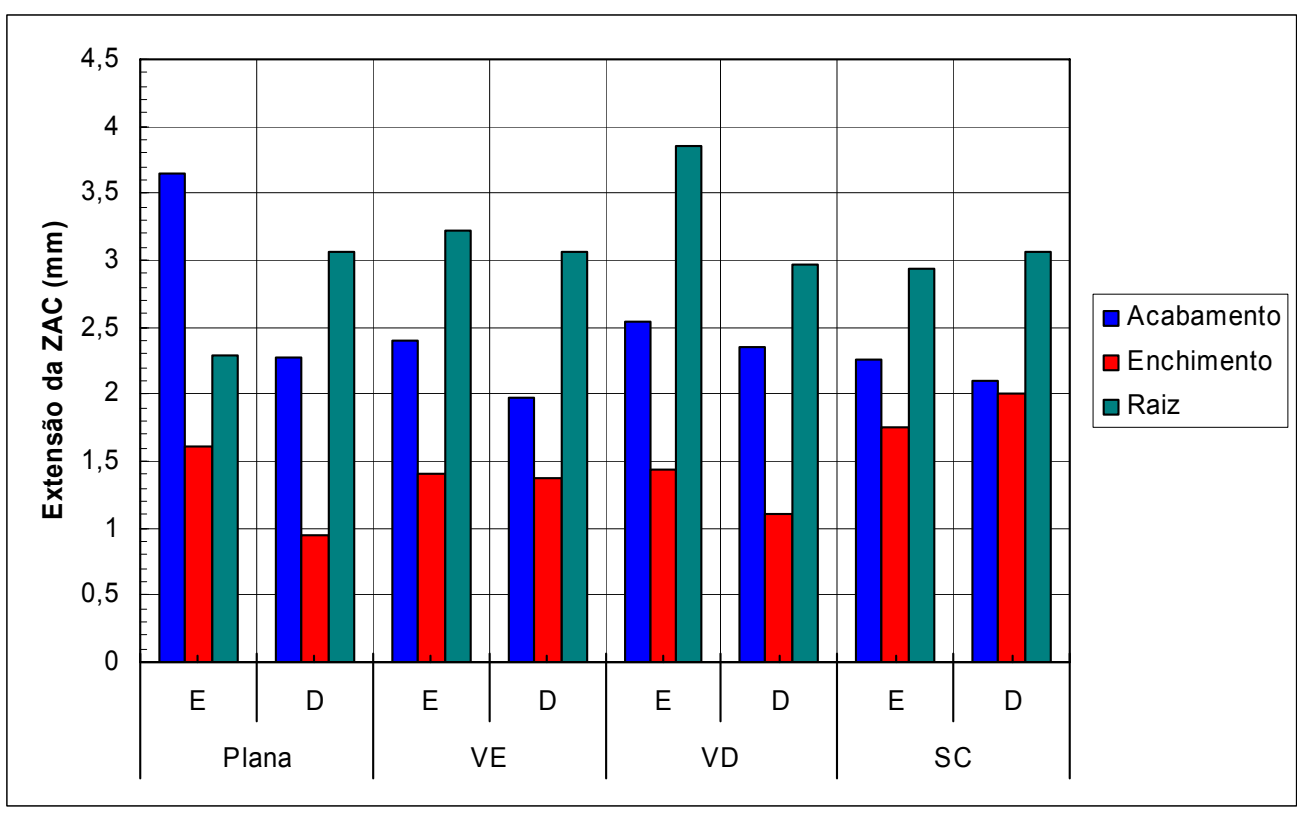

Figura 70 Extensão da ZAC para o tubo 2, de acordo com os dados da tabela 36.

\subsubsection{Microscopia óptica:}

\subsubsection{Metal de base:}

A figura 71 apresenta a microestrutura do metal de base montada em formato de cubo a fim de permitir a melhor visualização da heterogeneidade da microestrutura em relação aos sentidos de laminação.

De acordo com a figura 71 , na vista superior é possível visualizar a diferenças nos tamanhos de grão e nas suas formas. A vista superior e a lateral apresentam grãos alongados, sendo os grãos maiores na vista superior. $\mathrm{Na}$ vista frontal, quase não se percebe os grãos alongados e a maneira como a chapa foi laminada. Nesta região os grãos tendem a ser mais equiaxias.

A microestrutura do metal base é composta de ferrita, bainita, perlita e MA, bem como fases intermetálicas (carbonetos e nitretos). Estas fases intermetálicas são devido a presença de elementos de liga como titânio, nióbio e vanádio. 


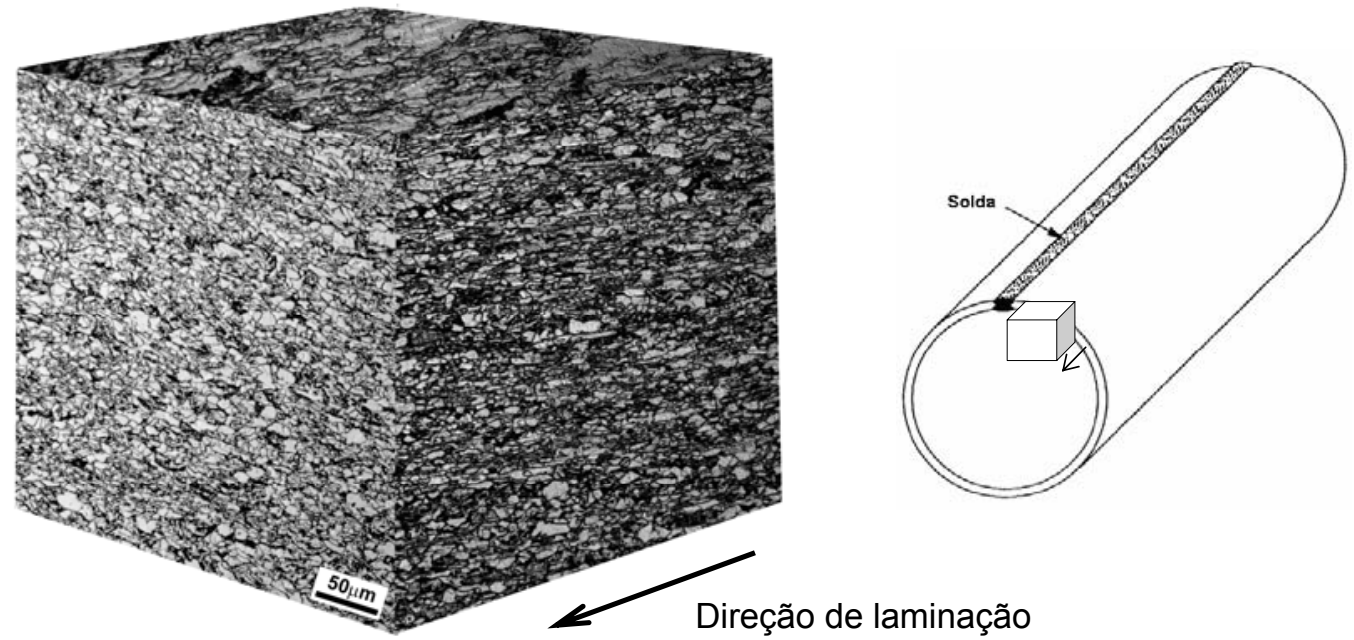

Figura 71 - Microestrutura do metal de base montada em formato de cubo para permitir a visualização da sua anisotropia.

\subsubsection{Juntas soldadas;}

A figura 72 apresenta uma montagem da microestrutura do passe de raiz do tubo1, partindo do metal de solda da raiz em direção ao metal de base, passando pela zona de ligação e ZAC, empregando-se o ataque Nital 2\%.

A figura 73 apresenta a mesma montagem da figura 71, mostrando 0 detalhamento das regiões com o ataque colorido Klemm1 utilizando filtro azul, apresentando as regiões de MA (áreas brancas).

A figura 74 apresenta uma montagem da microestrutura do metal de solda dos cordões de enchimento do tubo 1, com ampliação de 500X, utilizando-se o ataque Nital $2 \%$.

A figura 75 apresenta a região de cruzamento entre o passe de raiz e a primeira camada do enchimento do tubo 1, em conjunto com a zona de ligação e a ZAC no metal de base, empregando-se o ataque Nital $2 \%$.

A figura 76 apresenta a mesma região de cruzamento da figura 74 , mostrando detalhes do metal de solda e da ZAC utilizando o reagente Klemm1 com filtro azul e o ataque Nital $2 \%$

A figura 77 apresenta a região de cruzamento entre cordões de uma mesma camada com a camada inferior, apresentando as respectivas ZAC superpostas, empregando-se o ataque Nital $2 \%$. 


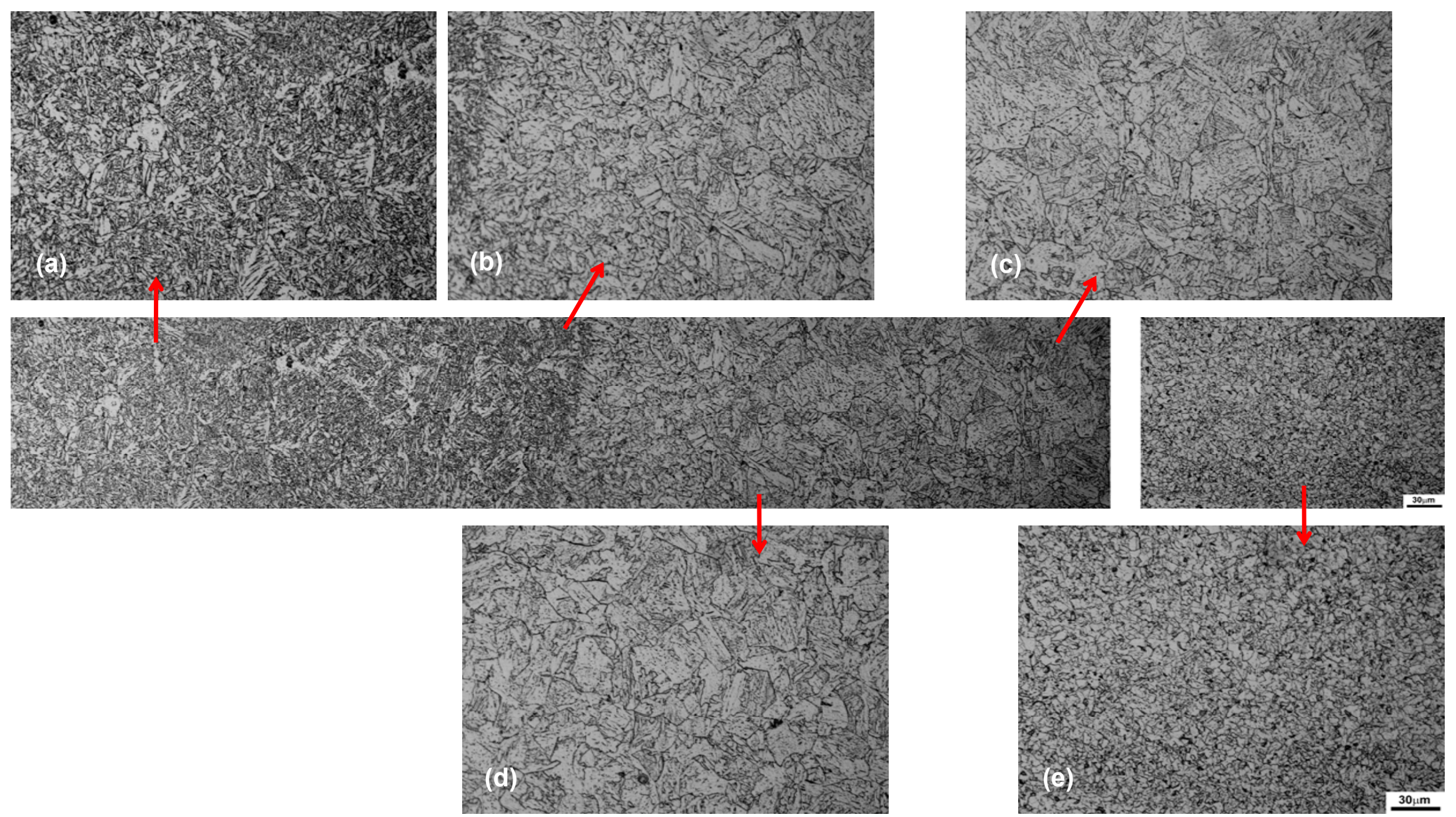

Figura 72 - Montagem da microestrutura do passe de raiz do tubo 1, em direção ao metal de base, mostrando a zona fundida (a), a zona de ligação (b), a ZAC (c, d) e o metal base (e). Ataque: Nital $2 \%$. 


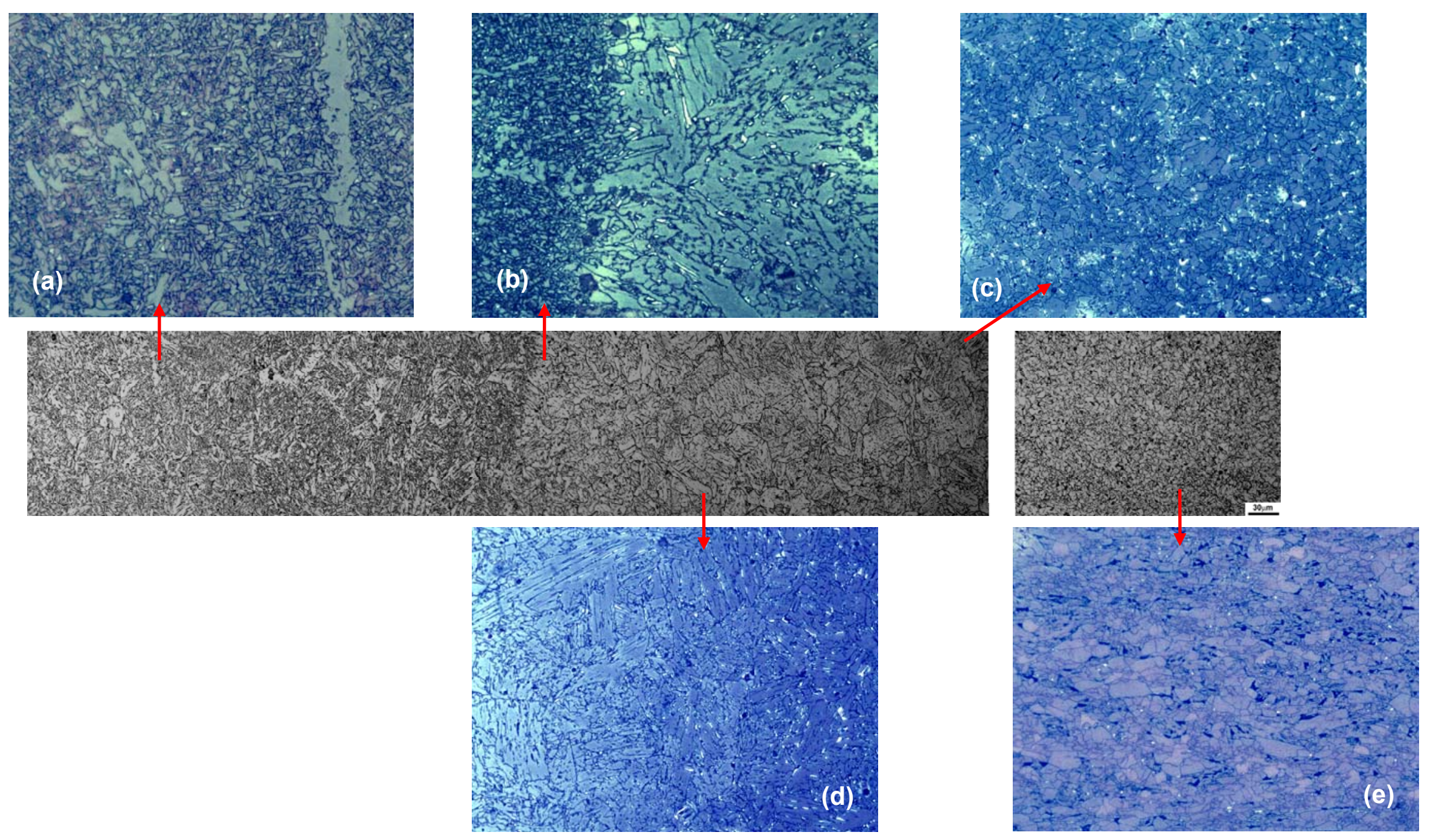

Figura 73- Montagem da microestrutura do passe de raiz do tubo 1, em direção ao metal de base, mostrando a zona fundida (a), a zona de ligação (b), a ZAC (c, d) e o metal base (e). Ataques: Nital 2\% e Klemm 1 com filtro azul. Aumento: 1000X. 


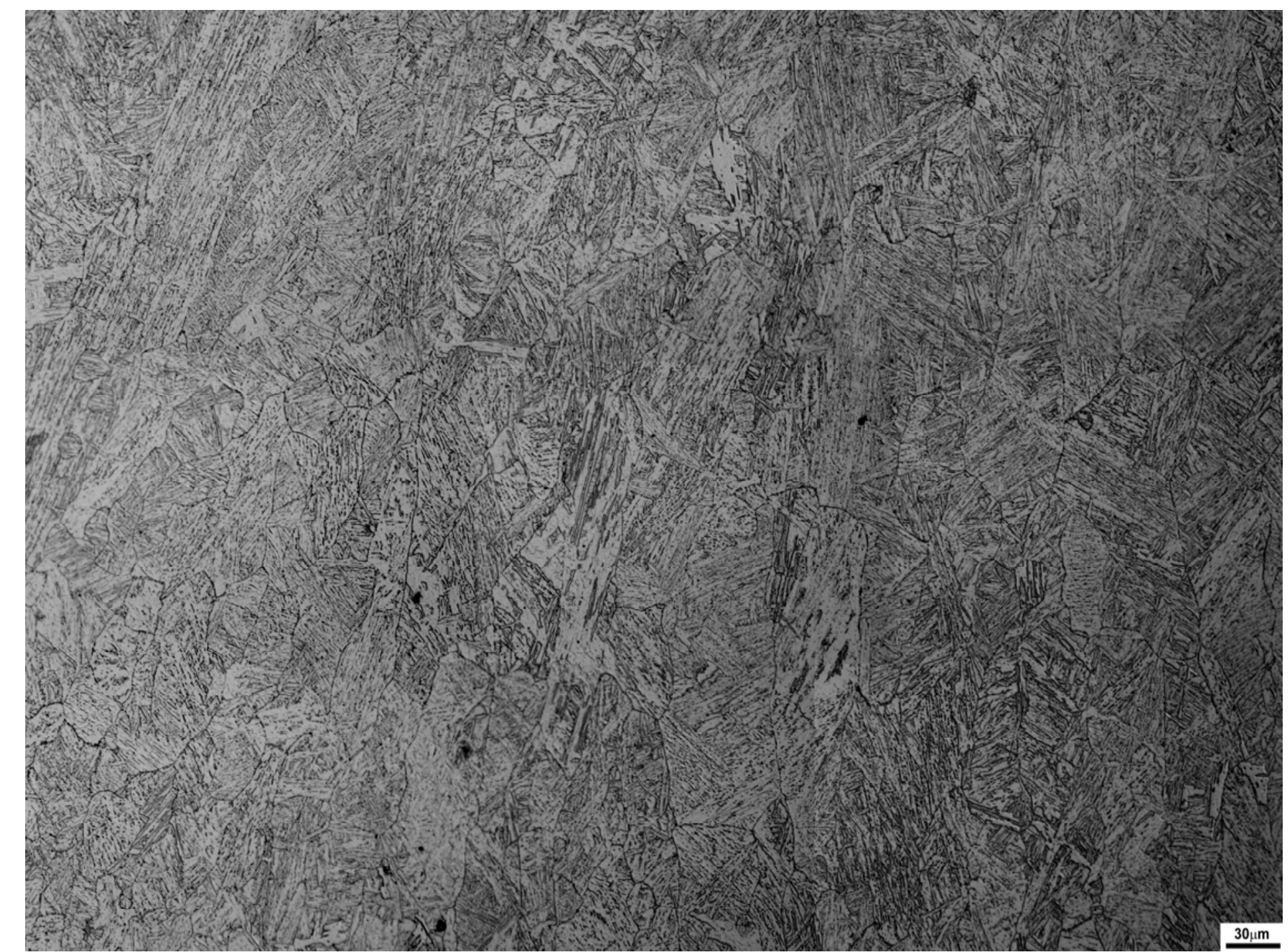

Figura 74- Montagem da microestrutura do metal de solda do passe de enchimento do tubo 1. Ataque: Nital $2 \%$. 


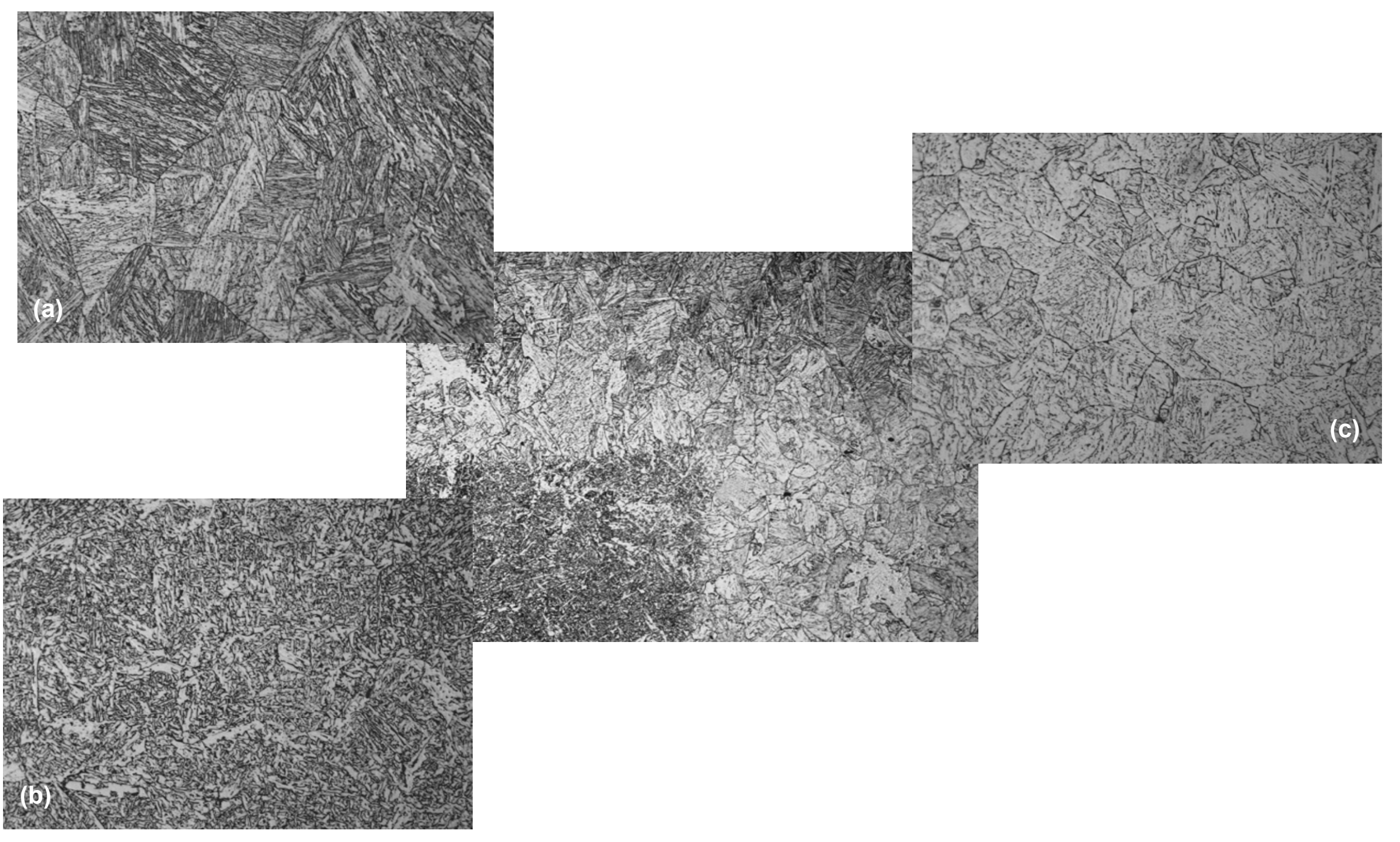

Figura 75 - Região de cruzamento entre o passe de raiz e a primeira camada do enchimento do tubo 1, mostrando o metal de solda do passe de enchimento (a), o metal de solda do passe de raiz (b) e a ZAC do metal de base (c). Ataque: Nital $2 \%$. 


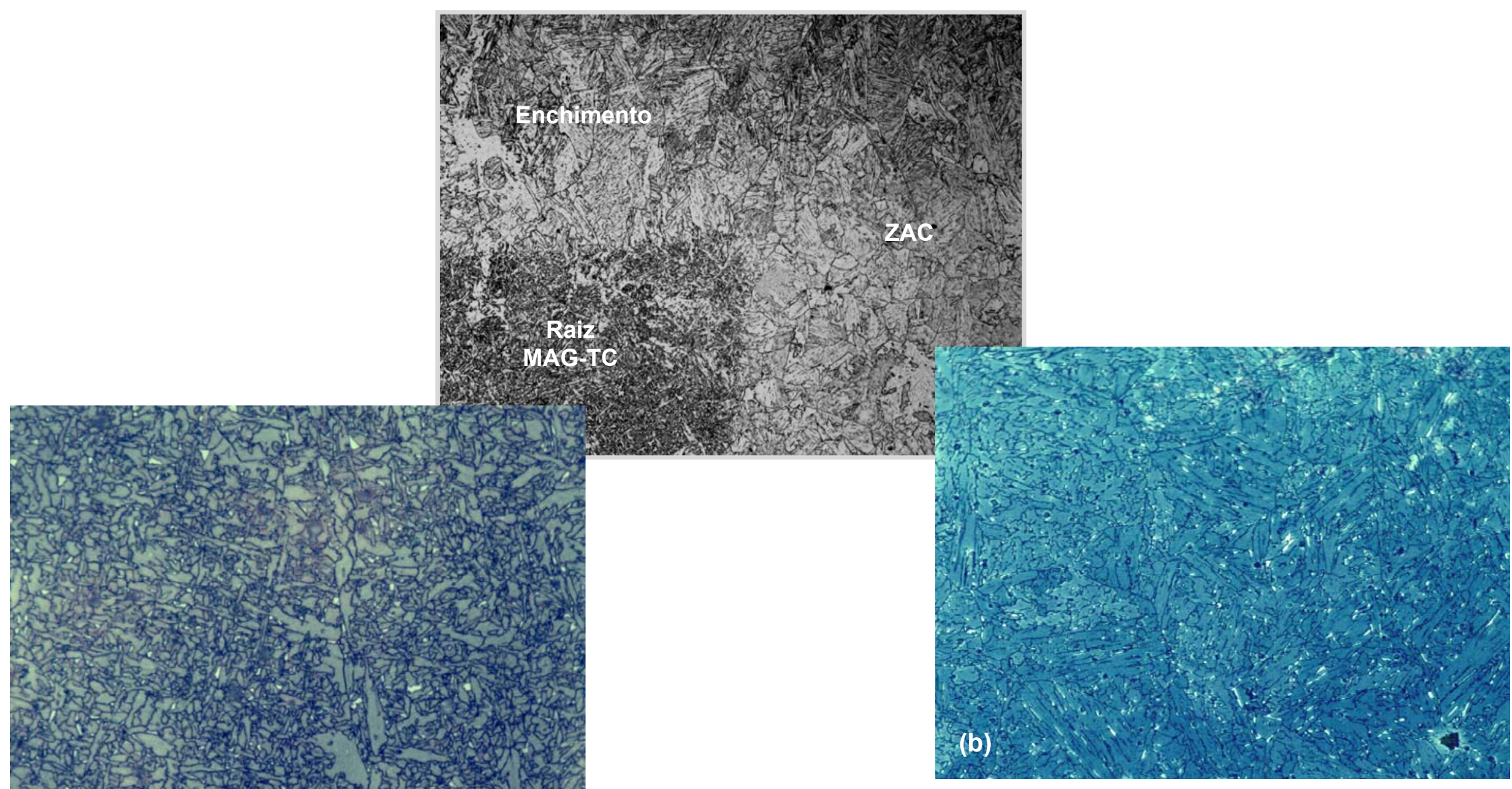

Figura 76 - Região de cruzamento entre o passe de raiz e a primeira camada do enchimento do tubo 2, apresentando detalhes da microestrutura da raiz (a) e da ZAC (b). Ataques: Nital $2 \%$ e Klemm1 com filtro azul. 


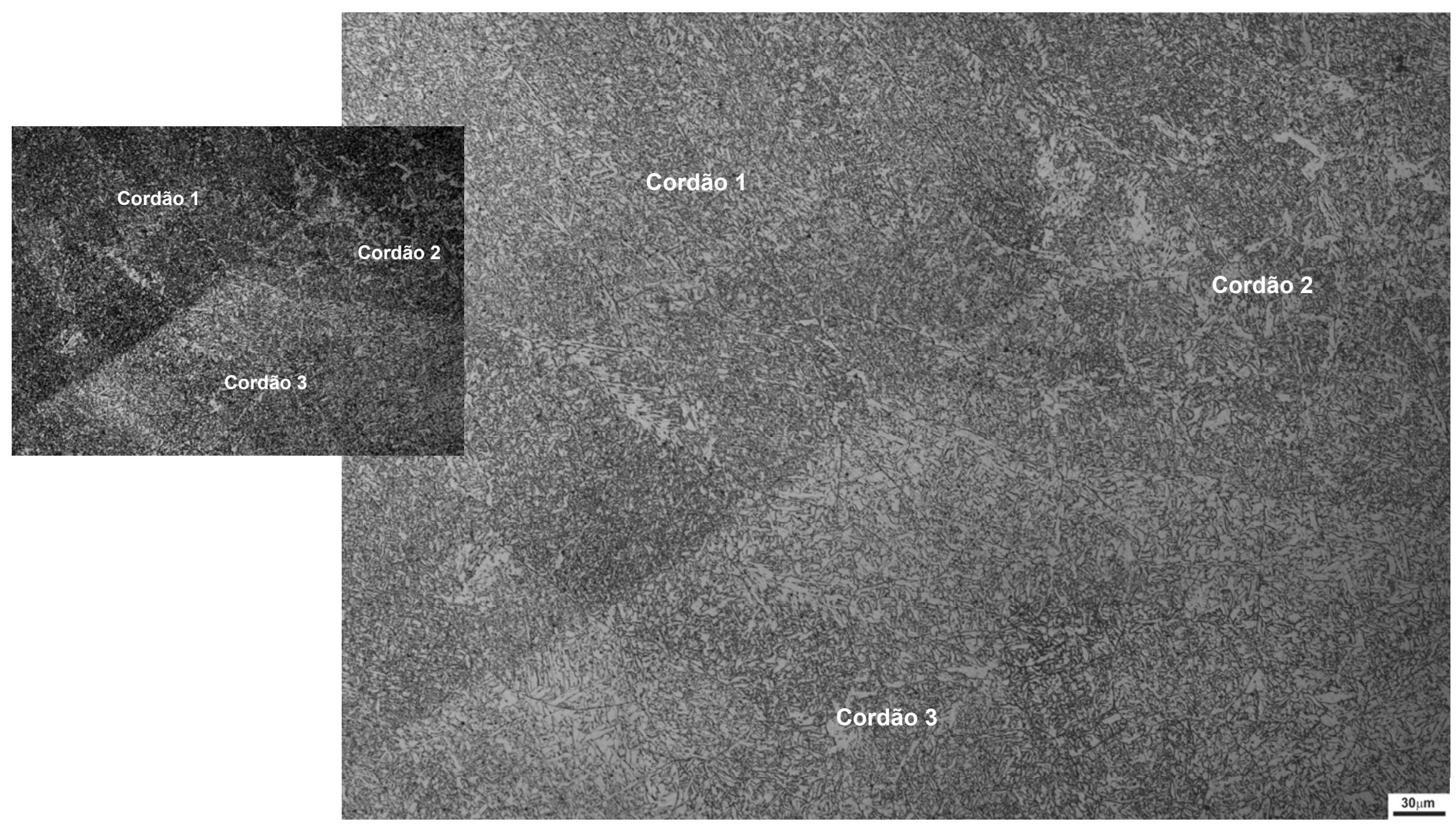

Figura 77- Região de cruzamento do metal de solda de três cordões na região de enchimento do tubo 2, mostrando as respectivas ZACs. Ataque: Nital $2 \%$. 
A figura 72 apresenta uma montagem da microestrutura do passe de raiz do tubo1, partindo do metal de solda da raiz em direção ao metal de base, passando pela zona de ligação e ZAC utilizando aumento de 500x. Pela observação da zona fundida na figura 72(a) é possível visualizar que a microestrutura obtida no centro do cordão, onde a velocidade de resfriamento é maior, consiste de ferrita acicular (AF) e ferrita no contorno de grão (GF) mais o microconstituinte MA. A figura 72(b) apresenta a ZAC próxima da zona de ligação, onde nota-se o crescimento do tamanho de grão ocasionado pelo ciclo térmico imposto na região, e conseqüente refino do tamanho de grão nas figuras 72(c) a 72(d), mais distantes do centro do cordão na temperatura intercrítica (final da ZAC) até a região do metal de base. A microestrutura nesta região é composta de bainita superior e MA. Na figura 72(e), onde é possível visualizar que a microestrutura apresentada consiste de ferrita, bainita, perlita e MA, bem como fases intermetálicas (carbonetos e nitretos).

A figura 73 apresenta a mesma montagem da figura 72 com o mesmo aumento mostrando o detalhamento das regiões com $\mathrm{O}$ ataque colorido Klemm1, no qual é possível visualizar o microconstituinte MA (pontos brancos). $\mathrm{Na}$ figura 73(a) observa-se a microestrutura obtida no centro do cordão, região na qual apresenta a maior taxa de resfriamento, consistindo de ferrita acicular $(A F)$ e ferrita poligonal intragranular (PF), MA e fases intermetálicas (carbonetos e nitretos). Na figura 73(b) visualiza-se a ZAC em região próxima a zona de ligação, notando-se o característico crescimento de grão. Na figura 73(c) observa-se a ZAC apresentando refino de grão, consistindo em bainita superior e MA, em região mais distante do centro do cordão de solda, e na figura 73(d) a ZAC na região de temperatura intercrítica, apresentando grão com tamanho reduzido, consistindo em bainita superior e MA, em região ainda mais distante do centro do cordão de solda. Na figura (e) apresenta-se o metal de base, consistindo dos mesmos microconstituintes da figura 73(e).

A figura 74 apresenta uma montagem da microestrutura do enchimento do tubo 1, com ampliação de 500x , consistindo de martensita (M), reaquecida pelos passes subseqüentes, ferrita com martensita, austenita ou carbonetos alinhados (AC) e MA.

A figura 75 apresenta a região de cruzamento entre o passe de raiz e a primeira camada do enchimento, em conjunto com a zona de ligação e a ZAC 
no metal de base. Na figura 75(a) é apresentada a microestrutura do metal de solda do cordão de enchimento consistindo de martensita (M),, ferrita com martensita, austenita ou carbonetos alinhados (AC) e MA. Na figura 75(b) apresenta-se a microestrutura da zona fundida do passe de raiz, onde é possível visualizar os microconstituintes ferrita acicular (AF), grãos de ferrita intergranular poligonal (PF) e MA. Na figura 75(c) é apresentada a microestrutura da ZAC do metal de base, já apresentada nas figuras 71 a 73 .

A figura 76 apresenta a mesma região de cruzamento da figura 75 , mostrando detalhes do metal de solda e da ZAC utilizando o reagente Klemm1, para ressaltar a quantidade de MA presente na microestrutura. Pode-se observar na figura 76(a) que a região do centro do metal de solda da raiz com ampliação de 1000x, consiste de ferrita acicular (AF), grãos de ferrita intergranular poligonal (PF), MA e intermetálicos. Na figura 76(c) observa-se a microestrutura da ZAC do metal de base, já apresentada anteriormente,

A figura 77 apresenta a região de cruzamento de 2 cordões de uma mesma camada com a camada inferior do tubo 2, apresentando as respectivas ZAC superpostas. A seqüência de soldagem consistiu primeiramente na soldagem do cordão 3 , pertencente a uma camada do enchimento inferior ao dos cordões 1 e 2. Nesta camada, o cordão 2 foi soldado antes do cordão 1 . A microestrutura resultante dos cordões de solda consiste em ferrita acicular $(A F)$, grãos de ferrita intergranular poligonal $(P F)$ e $M A$.

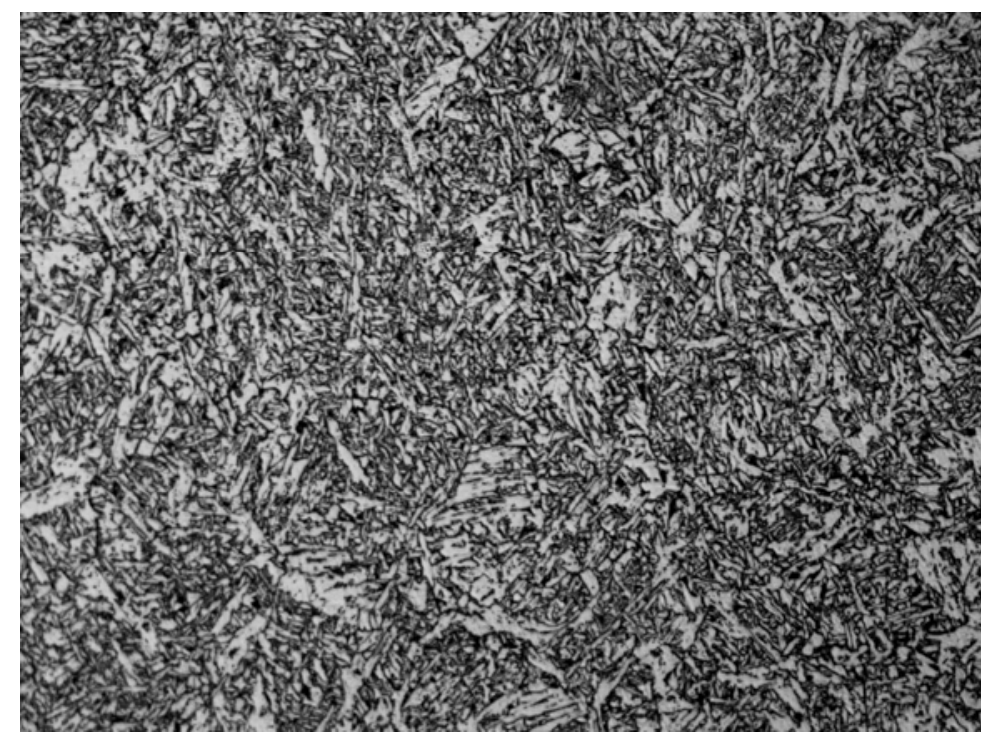

Figura 78- Microestrutura do metal de solda da raiz do tubo 2. Ataque: Nital $2 \%$. Aumento: 500X. 
As figuras 78 e 79 apresentam a microestrutura do metal de solda do passe de raiz zona de ligação entre o metal de solda da raiz do tubo 2, respectivamente.

Na figura 78 observa-se uma microestrutura composta de ferrita acicular $(A F)$ e ferrita poligonal intragranular (PF), MA e fases intermetálicas (carbonetos e nitretos).

$\mathrm{Na}$ figura 79 nota-se na zona fundida a mesma microestrutura da figura 78. A microestrutura é composta principalmente de bainita superior e MA.

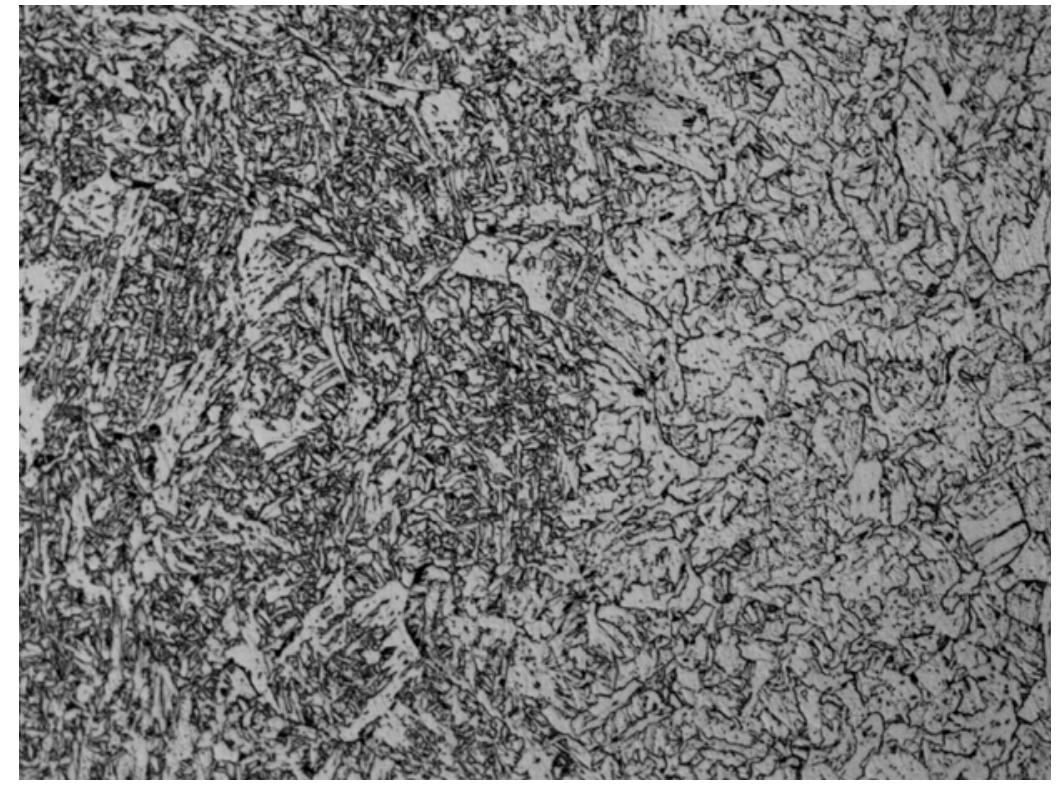

Figura 79 - Microestrutura da zona de ligação do metal de solda da raiz do tubo 2 com a ZAC. Ataque: Nital 2\%. Aumento: 500X.

\subsubsection{Quantidade de MA:}

A quantidade de MA foi determinada por duas técnicas: saturação magnética (representando volume) e por metalografia quantitativa (representando plano) através da contagem da fase, revelada pelo ataque Klemm 1.

\subsubsection{Saturação magnética:}

A tabela 38 apresenta o teor de MA das regiões da raiz, enchimento e acabamento, inclusive suas respectivas ZACs, para a as amostras das posições de soldagem plana e vertical direita de ambos os tubos, bem como do metal de base. 
Tabela 38 - Teor de MA das diversas regiões da junta, para as posições plana e vertical de ambos os tubos.

\begin{tabular}{|c|c|c|c|}
\hline Amostra & Região & Jsat & Teor MA\% \\
\hline \multirow{6}{*}{ T1PL } & Raiz & 207,85 & 5,3 \\
\hline & ZAC & 196,96 & 10,2 \\
\hline & Enchimento & 211,57 & 3,6 \\
\hline & ZAC & 197,88 & 9,8 \\
\hline & Acabamento & 206,97 & 5,7 \\
\hline & ZAC & 204,81 & 6,6 \\
\hline \multirow{6}{*}{ T1VD } & Raiz & 200,16 & 8,8 \\
\hline & ZAC & 202,18 & 7,8 \\
\hline & Enchimento & 205,32 & 6,4 \\
\hline & ZAC & 193,07 & 12,0 \\
\hline & Acabamento & 206,09 & 6,1 \\
\hline & ZAC & 191,84 & 12,6 \\
\hline \multirow{6}{*}{ T2PL } & Raiz & 190,57 & 13,1 \\
\hline & ZAC & 212,08 & 3,3 \\
\hline & Enchimento & 209,64 & 4,4 \\
\hline & ZAC & 199,12 & 9,2 \\
\hline & Acabamento & 213,56 & 2,7 \\
\hline & ZAC & 211,84 & 3,4 \\
\hline \multirow{6}{*}{ T2VD } & Raiz & 203,34 & 7,3 \\
\hline & ZAC & 202,98 & 7,5 \\
\hline & Enchimento & 197,91 & 9,8 \\
\hline & ZAC & 199,25 & 9,2 \\
\hline & Acabamento & 194,14 & 11,5 \\
\hline & ZAC & 192,59 & 12,2 \\
\hline MB & Média & 206,61 & 5,8 \\
\hline MBTT & Referência (Jref) & 219,38 & - \\
\hline
\end{tabular}

A figura 80 apresenta o teor de MA para cada região da junta soldada e sua respectiva ZAC, para ambos os tubos e posições de soldagem, de acordo com os dados da tabela 38.

Pela análise da figura 80 , observa-se que a maioria das regiões apresenta MA maior que o metal base. Com os dados da referência 26 e empregando-se a contagem por pontos do agregado MA, obteve-se a figura 81.

Segundo a figura 81, quanto maior a velocidade, maior a quantidade de MA formada, conforme se observa nos passes finais apresentados na figura 80. A região delimitada por linhas tracejadas na figura mostram as velocidades de resfriamento de diferentes regiões da junta soldada. Por esta abordagem, o teor de MA ficaria entre 8 e 10,5\%.

Não se pode esquecer que a comparação entre a figura 80 e 81 torna-se difícil por diversos motivos como: alteração da composição química na junta soldada, a temperatura máxima atingida na ZAC e os reaquecimentos pelos passes subseqüentes, que tendem a diminuir o teor de MA. 


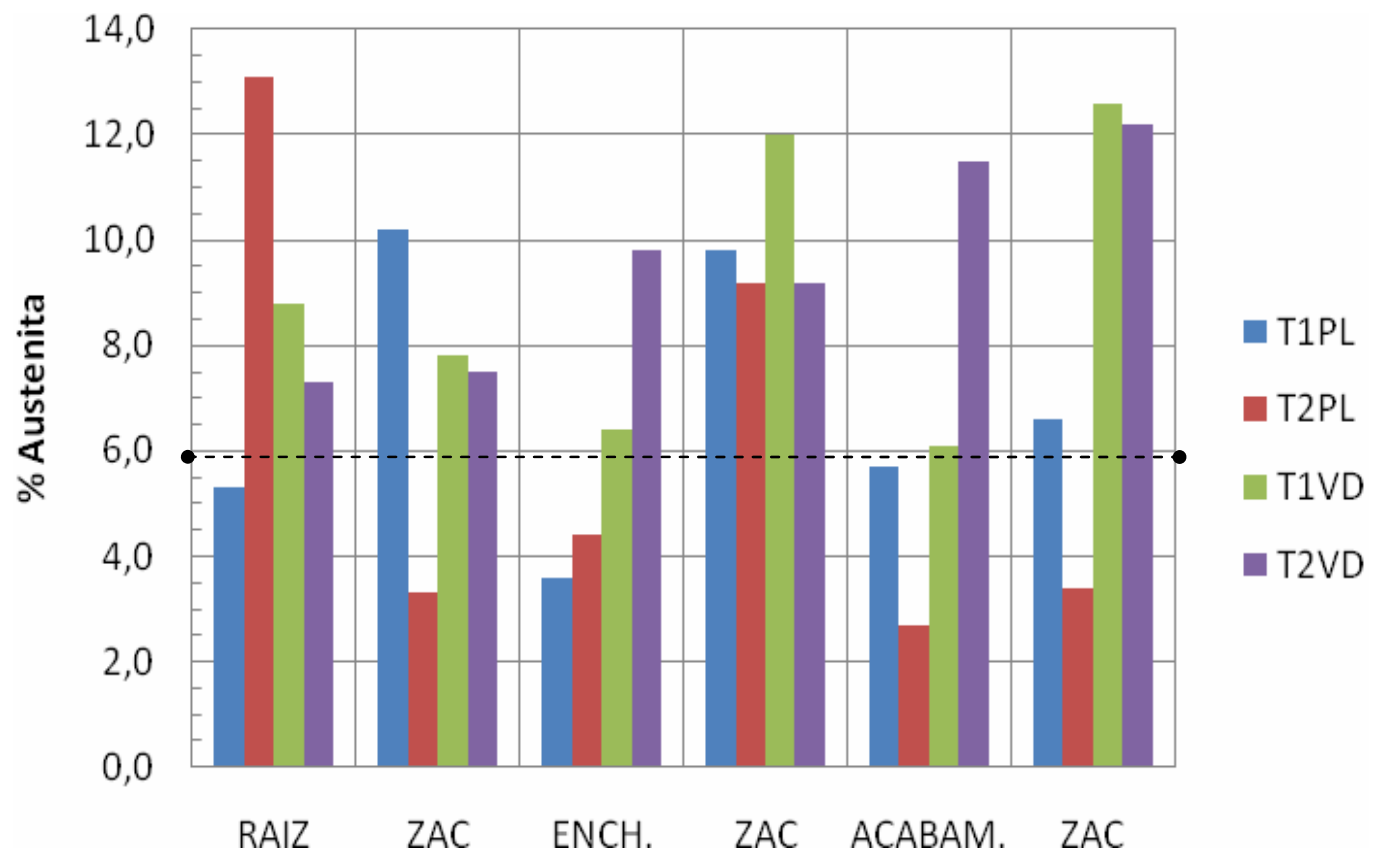

Figura 80 - Teor de MA para as amostras das posições de soldagem plana e vertical, de ambos os tubos. A linha tracejada mostra a média do MA do metal de base.

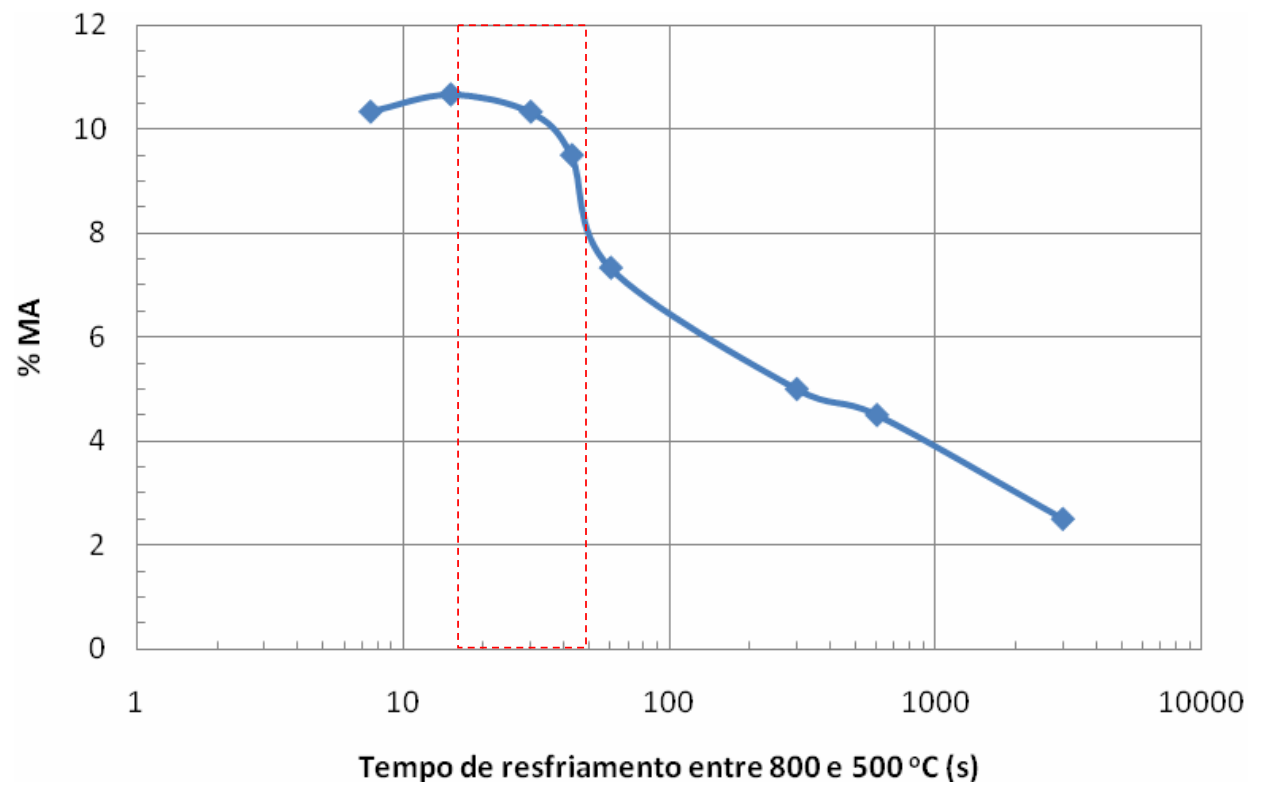

Figura 81- Teor de MA em função do tempo de resfriamento entre 800 e $500^{\circ} \mathrm{C}$. 


\subsubsection{Metalografia quantitativa:}

A figura 82 apresenta uma estimativa do teor de MA obtida através de metalografia quantitativa das amostras atacadas com o reagente Klemm1 apresentadas nas figuras 73 e 76.

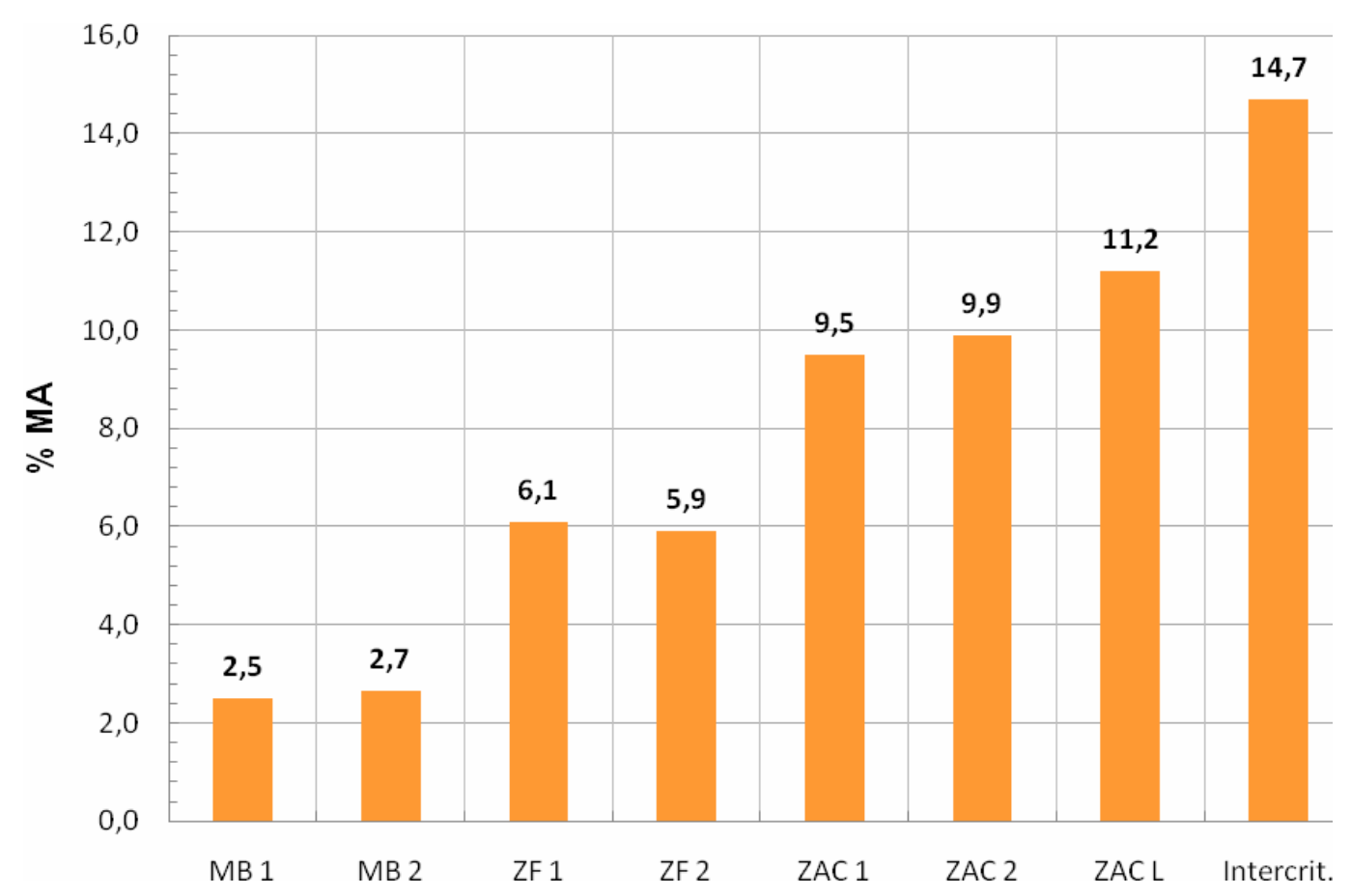

Figura 82- Teor de MA estimado através de metalografia quantitativa das micrografias das figuras 73 e 76 .

Comparando-se os valores obtidos na figura 82 com os da figura 80 , nota-se que o teor encontrado para o metal de base é cerca da metade do valor encontrado no ensaio magnético. Este fato pode estar relacionado com a sensibilidade dos ensaios empregados. O ensaio magnético consegue detectar agregados MA não visíveis por microscopia óptica. Ao mesmo tempo, a dimensão dos corpos-de-prova para este ensaio podem gerar erros de posicionamento das amostras, justificando as diferenças e dispersões observadas. 


\subsection{Ensaios Mecânicos:}

\subsubsection{Ensaio de dureza:}

A tabela 39 apresenta a dureza média encontrada para o metal de base.

Tábela 39- Dureza média do metal de base.

\begin{tabular}{|c|c|}
\hline Região & Dureza HV5 \\
\hline Metal de base & 230 \\
\hline
\end{tabular}

As tabelas 40 e 41 apresentam as durezas encontradas conforme a região da junta soldada do tubo 1 e 2 em função das posições de soldagem e suas respectivas camadas, de acordo com o perfil da figura 39 , e as figuras 83 e 84 apresentam graficamente os dados das tabelas 40 e 41 . 0 espaçamento de $1 \mathrm{~mm}$ adotado entre os pontos e a margem da solda provou-se eficaz, de acordo com a extensão da ZAC apresentada na figura 68.

A partir da análise da figura 83 , observa-se que houve a tendência da curva de dureza tender ao formato da letra "W". A dureza encontrada nas regiões do metal de base foram maiores em praticamente todas as posições, a exceção da vertical direita, onde houve pouca variação nos valores de dureza nas diferentes regiões da junta soldada. Os pontos da ZAC apresentaram os menores valores de dureza entre todos os pontos medidos, novamente a exceção da vertical direita, onde houve pouca variação nas medições de dureza. A dureza medida na região do metal de solda apresentou a tendência de possuir valor intermediário entre o metal de base e a ZAC.

$O$ passe de raiz, entre todas as posições estudadas, apresentou a tendência de possuir a menor dureza, frente aos passes de enchimento e acabamento. Este resultado é devido ao reaquecimento sucessivo que estes passes sofreram durante a soldagem, produzindo um efeito similar a um tratamento térmico de "revenimento". Este tratamento térmico além de reduzir a dureza pode ter causado a precipitação de fases intermetálicas que podem fragilizar a junta soldada. Outro fator que poder ter reduzido a dureza é a diferença de composição química no metal de solda do passe de raiz, que é bem diferente do metal base e dos passes de enchimento e acabamento. 
Tábela 40- Dureza Vickers HV5 das regiões da junta soldada do tubo 1 em função das posições de soldagem e camadas.

\begin{tabular}{|c|c|c|c|c|c|}
\hline \multicolumn{6}{|c|}{ Posição de soldagem: Plana } \\
\hline & \multicolumn{5}{|c|}{ Posição na junta soldada } \\
\hline & MB & ZAC & MS & ZAC & MB \\
\hline Camadas & \multicolumn{5}{|c|}{ Dureza Vickers (HV5) } \\
\hline Acabamento & 240,0 & 174,7 & 176,9 & 180,4 & 230,3 \\
\hline Enchimento & 236,2 & 163,5 & 186,3 & 180,0 & 214,2 \\
\hline Raiz & 238,6 & 163,2 & 184,1 & 164,9 & 247,0 \\
\hline \multicolumn{6}{|c|}{ Posição de soldagem: Vertical descendente lado direito } \\
\hline & \multicolumn{5}{|c|}{ Posição na junta soldada } \\
\hline & MB & ZAC & MS & ZAC & MB \\
\hline Camadas & \multicolumn{5}{|c|}{ Dureza Vickers (HV5) } \\
\hline Acabamento & 228,3 & 210,1 & 232,1 & 203,4 & 223,3 \\
\hline Enchimento & 208,1 & 229,5 & 202,2 & 189,9 & 209,7 \\
\hline Raiz & 234,9 & 205,9 & 200,2 & 225,1 & 228,4 \\
\hline \multicolumn{6}{|c|}{ Posição de soldagem: Vertical descendente lado esquerdo } \\
\hline & \multicolumn{5}{|c|}{ Posição na junta soldada } \\
\hline & MB & ZAC & MS & ZAC & MB \\
\hline Camadas & \multicolumn{5}{|c|}{ Dureza Vickers (HV5) } \\
\hline Acabamento & 229,8 & 207,4 & 227,6 & 188,1 & 227,2 \\
\hline Enchimento & 216,8 & 196,2 & 218,0 & 193,2 & 189,5 \\
\hline Raiz & 220,2 & 190,2 & 213,0 & 207,1 & 229,2 \\
\hline \multicolumn{6}{|c|}{ Posição de soldagem: Sobrecabeça } \\
\hline & \multicolumn{5}{|c|}{ Posição na junta soldada } \\
\hline & MB & ZAC & MS & ZAC & MB \\
\hline Camadas & \multicolumn{5}{|c|}{ Dureza Vickers (HV5) } \\
\hline Acabamento & 235,6 & 233,7 & 219,1 & 195,8 & 222,5 \\
\hline Enchimento & 204,3 & 187,1 & 200,8 & 162,5 & 202,8 \\
\hline Raiz & 261,1 & 182,5 & 193,4 & 193,2 & 265,8 \\
\hline
\end{tabular}



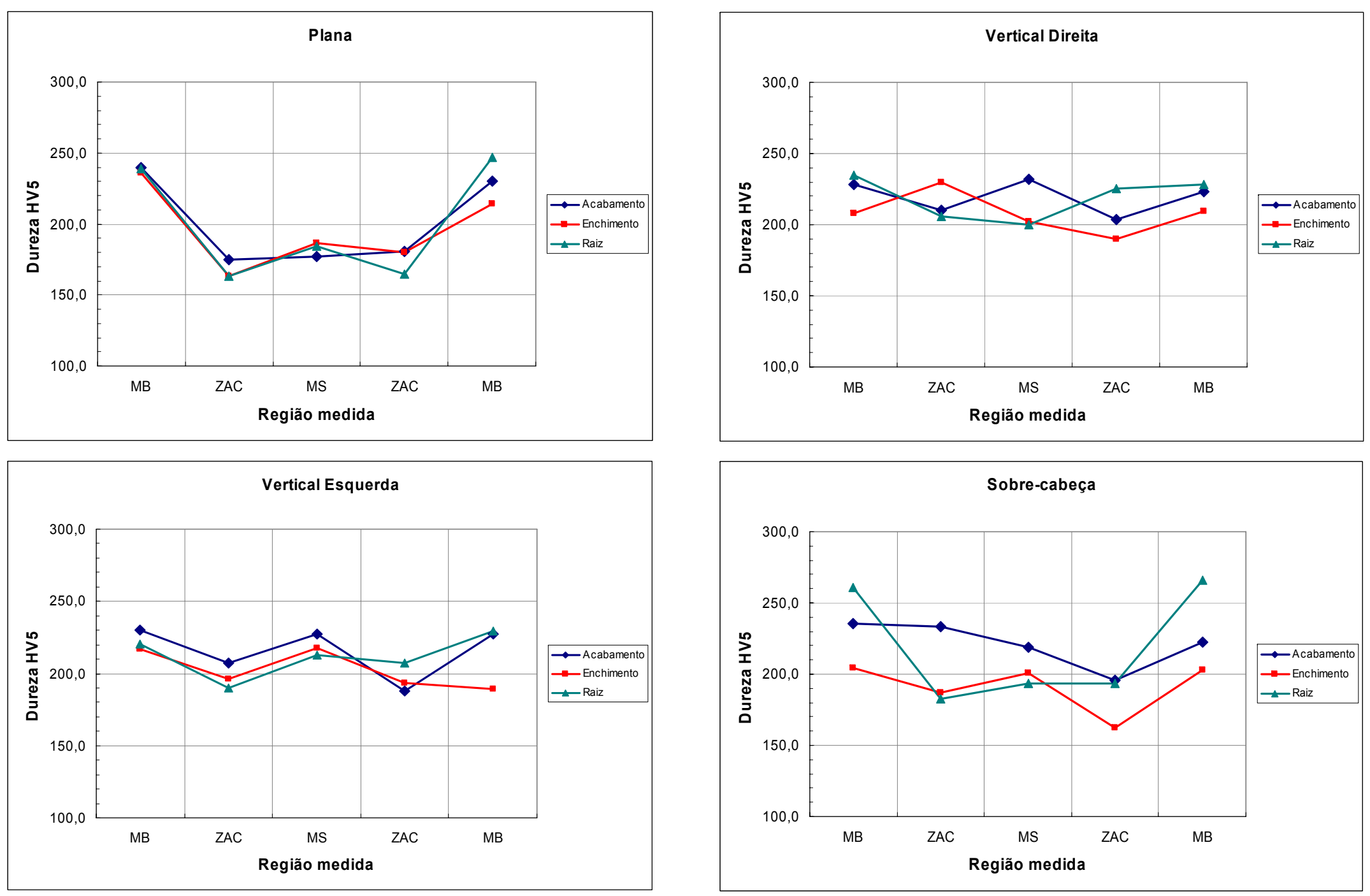

Figura 83 - Durezas Vickers HV5 das regiões soldadas do tubo 1 em função das posições de soldagem e camadas, baseada nos dados da tabela 38. 
Tabela 41- Dureza Vickers HV5 das regiões da junta soldada do tubo 2 em função das posições de soldagem e camadas.

\begin{tabular}{|c|c|c|c|c|c|}
\hline \multicolumn{6}{|c|}{ Posição de soldagem: Plana } \\
\hline & \multicolumn{5}{|c|}{ Posição na junta soldada } \\
\hline & MB & ZAC & MS & ZAC & MB \\
\hline Camadas & \multicolumn{5}{|c|}{ Dureza Vickers (HV5) } \\
\hline Acabamento & 247,0 & 195,3 & 206,2 & 171,7 & 236,3 \\
\hline Enchimento & 247,0 & 169,2 & 196,2 & 188,3 & 238,6 \\
\hline Raiz & 214,2 & 197,1 & 173,9 & 175,5 & 228,3 \\
\hline \multicolumn{6}{|c|}{ Posição de soldagem: Vertical descendente lado direito } \\
\hline & \multicolumn{5}{|c|}{ Posição na junta soldada } \\
\hline & MB & ZAC & MS & ZAC & MB \\
\hline Camadas & \multicolumn{5}{|c|}{ Dureza Vickers (HV5) } \\
\hline Acabamento & 228,4 & 175,9 & 185,3 & 177,4 & 208,1 \\
\hline Enchimento & 209,7 & 176,5 & 166,0 & 156,1 & 234,9 \\
\hline Raiz & 228,4 & 196,8 & 184,4 & 181,9 & 240,0 \\
\hline \multicolumn{6}{|c|}{ Posição de soldagem: Vertical descendente lado esquerdo } \\
\hline & \multicolumn{5}{|c|}{ Posição na junta soldada } \\
\hline & MB & ZAC & MS & ZAC & MB \\
\hline Camadas & \multicolumn{5}{|c|}{ Dureza Vickers (HV5) } \\
\hline Acabamento & 208,1 & 194,6 & 184,6 & 202,4 & 196,5 \\
\hline Enchimento & 181,3 & 216,2 & 196,9 & 227,3 & 213,2 \\
\hline Raiz & 212,4 & 190,1 & 204,1 & 209,7 & 244,1 \\
\hline \multicolumn{6}{|c|}{ Posição de soldagem: Sobrecabeça } \\
\hline & \multicolumn{5}{|c|}{ Posição na junta soldada } \\
\hline & MB & ZAC & MS & ZAC & MB \\
\hline Camadas & \multicolumn{5}{|c|}{ Dureza Vickers (HV5) } \\
\hline Acabamento & 187,3 & 205,0 & 184,7 & 190,8 & 217,9 \\
\hline Enchimento & 185,5 & 197,3 & 170,4 & 201,8 & 201,7 \\
\hline Raiz & 207,1 & 197,0 & 188,4 & 184,1 & 187,1 \\
\hline
\end{tabular}



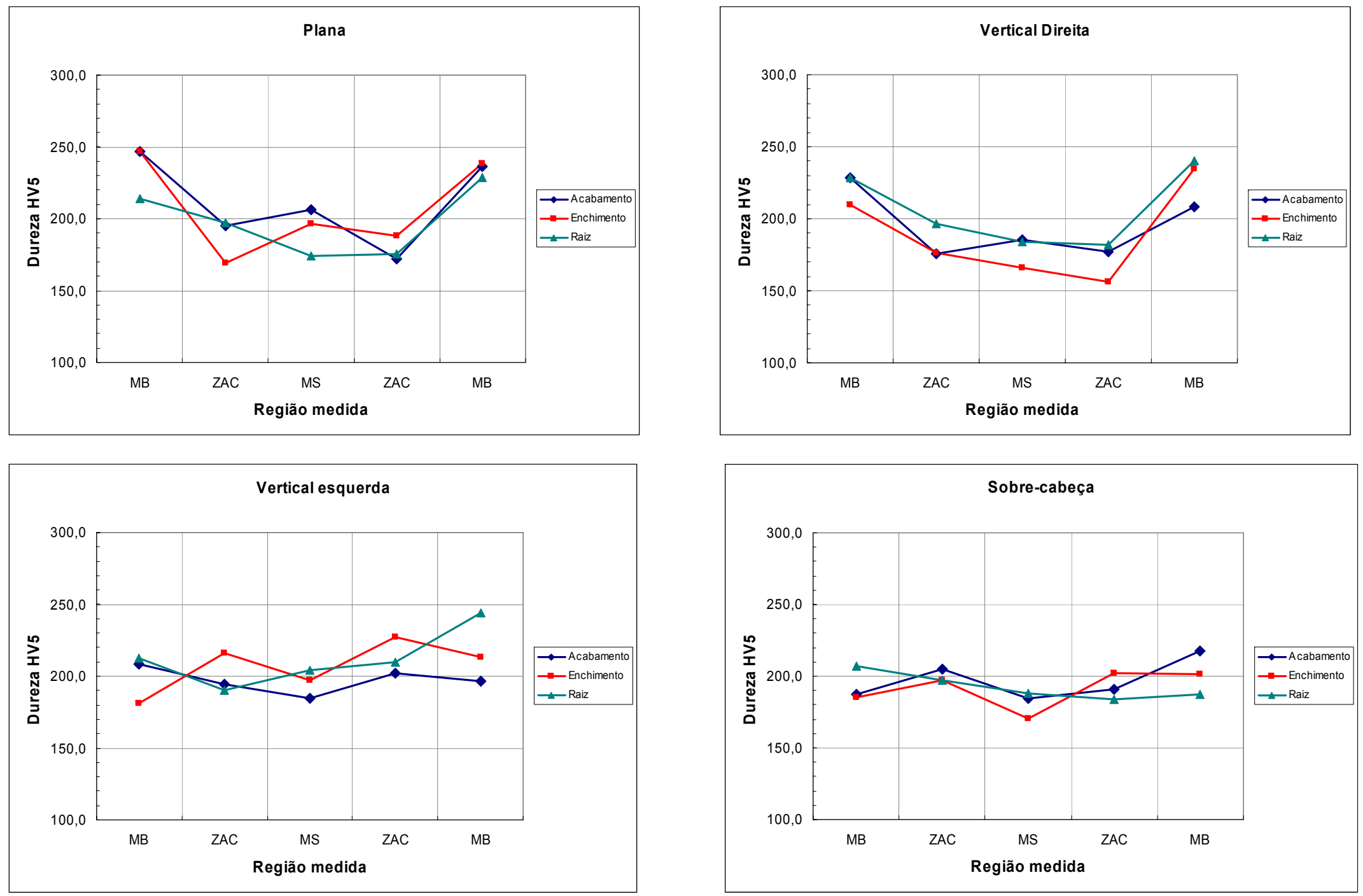

Figura 84 - Durezas Vickers HV5 das regiões soldadas do tubo 2 em função das posições de soldagem e camadas, baseada nos dados da tabela 40. 
Os passes de acabamento de todas as posições apresentaram a tendência de possuírem a maior dureza. Por conseguinte, os passes de enchimento apresentaram valores intermediários entre a raiz e o acabamento. Este fenômeno pode ser explicado pelos ciclos térmicos e pela composição química. Os sucessivos reaquecimentos da região da raiz pelos passes de enchimento e a região dos passes de enchimento pelos passes de acabamento, também produziram um efeito de um tratamento térmico similar ao de revenido, devido aos ciclos térmicos dos passes subseqüentes. Além disto, a composição química do metal de solda é diferente da do metal base e do passe de raiz. O enchimento e o acabamento possuem teor mais elevado de $\mathrm{Mn}, \mathrm{Al}$ e $\mathrm{N}$. Estes elementos químicos podem ter sido responsáveis pela diferença de dureza e pela alteração na microestrutura dos passes de enchimento do tubo1.

Pela análise da figura 84, observa-se que também houve a tendência da curva de dureza formar um "W", embora menos explícito nas posições vertical esquerda e sobre-cabeça. A dureza encontrada nas regiões do metal de base também foram maiores em praticamente todas as posições, a exceção da vertical esquerda e sobre-cabeça, onde houve maior uniformidade entre as medições. Os pontos da ZAC apresentaram os menores valores de dureza entre todos os pontos medidos, novamente a exceção da vertical esquerda e sobre-cabeça, onde houve menor variação nos valores das medições. A dureza medida na região do metal de solda apresentou a tendência de possuir valor intermediário entre o metal de base e a ZAC.

De forma diferente do tubo 1, o passe de raiz não apresentou a tendência de possuir a dureza mais baixa, frente aos passes de enchimento e acabamento. A exceção da posição plana, os passes de acabamento de todas as posições apresentaram a tendência de possuírem a maior dureza. Por conseguinte, os passes de enchimento apresentaram valores intermediários entre a raiz e o acabamento nas posições plana e vertical esquerda, sendo que na posição vertical direita e sobre-cabeça apresentou dureza mais baixa. Este fenômeno pode ser explicado pelo reaquecimento da região da raiz pelos passes de enchimento e a região dos passes de enchimento pelos de acabamento, devido à soldagem dos demais passes. Com relação à composição química, os passes de raiz e enchimento do tubo 2 apresentaram 
muito pouca variação na composição química, que é diferente da composição química do tubo 1.

\subsubsection{Ensaio de tração:}

\subsubsection{Metal de base;}

O limite de resistência e escoamento do metal de base (longitudinal e transversal) e da solda longitudinal do tubo, conforme API 5L [9], estão apresentadas na figura 85.

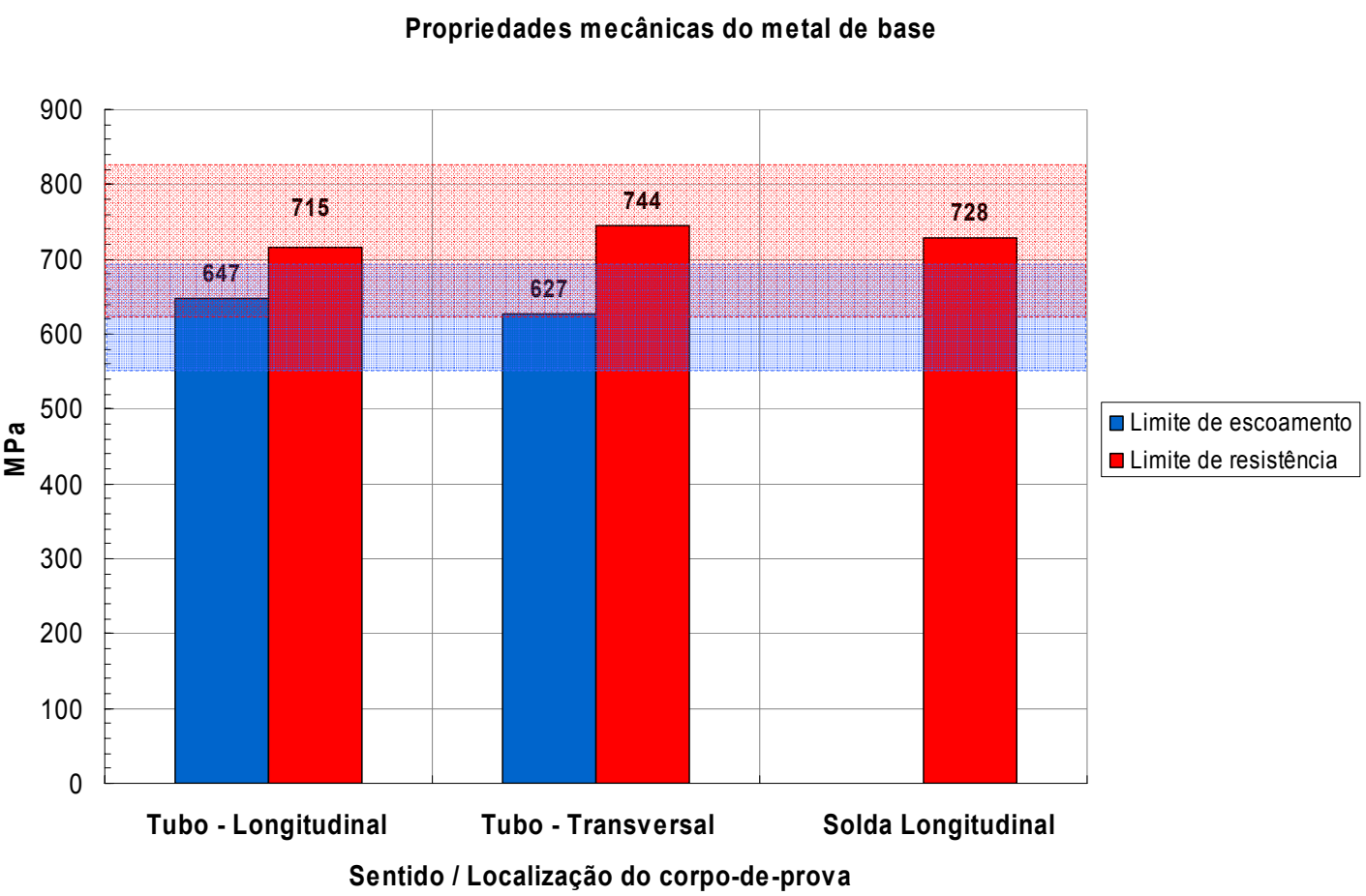

Figura 85 - Propriedades mecânicas do metal de base e da solda longitudinal do tubo, conforme API 5L [9].

Pela análise da figura 85 , pode-se observar que todos os limites de resistência e escoamento encontrados, tanto do tubo, quanto da solda longitudinal atendem os requisitos mínimos da especificação API 5L [9], representados pelas tarjas vermelha e azul na figura $O$. O maior limite de resistência foi encontrado nos corpos de prova ensaiados na direção 
transversal do tubo, enquanto que o maior limite de escoamento foi obtido na direção longitudinal. Este fenômeno é característico do efeito Bauschinger.

A relação LE/LR obtida com os dados da figura 86 é de 0,91 para os corpos de prova ensaiados no sentido longitudinal e de 0,84 no sentido transversal, ambos dentro do limite especificado na norma API 5L [9]. Tomando-se como base os menores valores do limite de resistência a tração e escoamento, a razão LE/LR obtida é de 0,88 , também dentro do limite especificado na norma API 5L [9].

A partir dos dados da figura 85 , foi calculado o fator de eficiência de junta, que é a razão entre o limite de escoamento e o limite de resistência na direção longitudinal e transversal. A eficiência de junta no sentido longitudinal é de $101,9 \%$ e no sentido transversal de $97,9 \%$.

A figura 86 apresenta uma fractografia da face da fratura do corpo de prova de tração longitudinal, apresentando caráter dúctil.

A análise da figura 86 mostra a presença de alvéolos ('dimples') na superfície da fratura, que são característicos de fratura dúctil. 


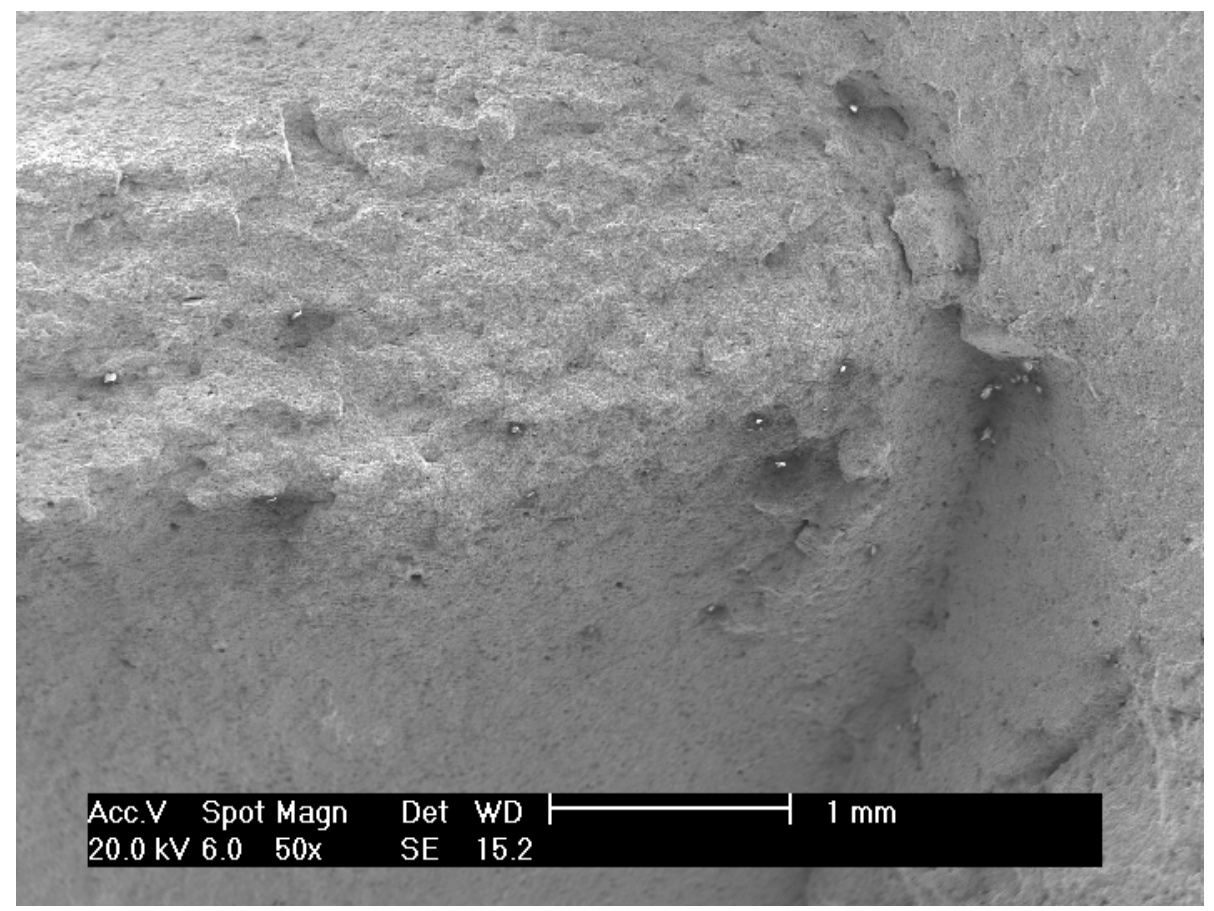

a-) Fractografia de um corpo de prova de tração do metal de base

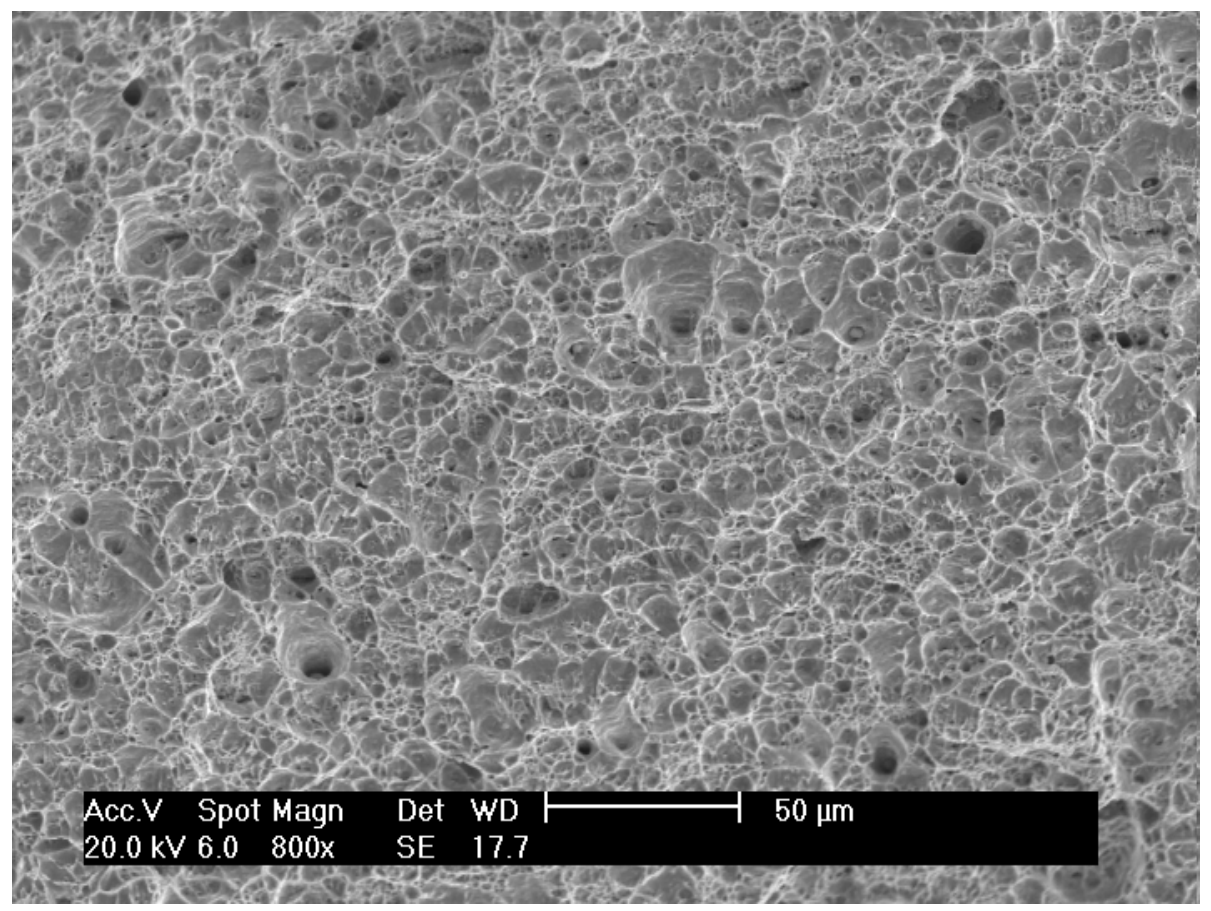

b-) fractografia da face de fratura do metal base, com aumento maior.

Figura 86 - Fractografia de um corpo de prova de tração do metal de base no sentido longitudinal, apresentando caráter dúctil. (a) baixo aumento (50X); (b) maior aumento (800X). 


\subsubsection{Solda circunferencial:}

Os limites de resistência e escoamento das soldas dos 4 quadrantes dos tubos 1 e 2, conforme norma API 1104 [8], são apresentadas na tabela 42 e na figura 87. A região delimitada pelo retângulo representa a variação admitida pela norma API 1104. A tabela 43 apresenta o local da fratura nos quatro quadrantes dos corpos de prova soldados.

Tabela 42- Limite de resistência da junta soldada, conforme API 1104.

\begin{tabular}{|c|c|c|c|}
\hline Tubo & Quadrante & Limite de resistência & Resultado conforme API 1104 \\
\hline \multirow{4}{*}{1} & 1 & 711 & Aprovado \\
\cline { 2 - 4 } & 2 & 710 & Aprovado \\
\cline { 2 - 4 } & 3 & 707 & Aprovado \\
\cline { 2 - 4 } & 4 & 711 & Aprovado \\
\hline \multirow{4}{*}{2} & 1 & 699 & Aprovado \\
\cline { 2 - 4 } & 2 & 703 & Aprovado \\
\cline { 2 - 4 } & 3 & 688 & Aprovado \\
\cline { 2 - 4 } & 4 & 706 & Aprovado \\
\hline
\end{tabular}

Limite de resistência da junta soldada

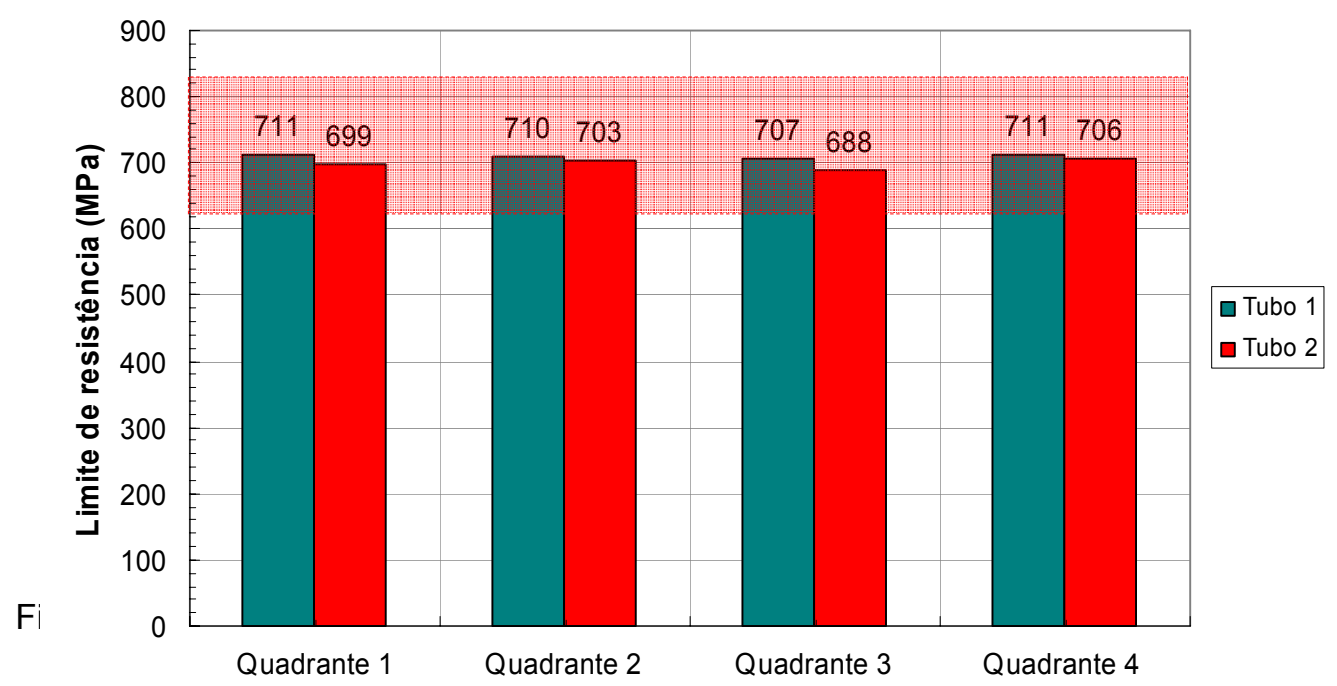

Figura 87 - Limite de resistência das soldas circunferenciais, conforme API 1104 [8].

Pela análise da figura 87 , nota-se que todas as juntas soldadas obtiveram o limite de resistência um pouco acima do limite do metal de base, 
representado pela tarja vermelha, conforme critério de aceitação da norma API 1104 [8], tendo sido considerados como aprovados.

Tabela 43 - Local de fratura dos comos de prova do ensaio de tração, conforme API 1104 [8].

\begin{tabular}{|c|c|c|}
\hline Tubo & Corpo de prova & Fratura: \\
\hline \multirow{4}{*}{1} & Quadrante 1 & MB \\
\cline { 2 - 3 } & Quadrante 2 & ZAC \\
\cline { 2 - 3 } & Quadrante 3 & $\mathrm{MB}$ \\
\cline { 2 - 3 } & Quadrante 4 & $\mathrm{MB}$ \\
\hline \multirow{4}{*}{2} & Quadrante 1 & $\mathrm{ZAC}$ \\
\cline { 2 - 3 } & Quadrante 2 & $\mathrm{MB}$ \\
\cline { 2 - 3 } & Quadrante 3 & $\mathrm{LF}$ \\
\cline { 2 - 3 } & Quadrante 4 & $\mathrm{MB}$ \\
\hline
\end{tabular}

Segundo a tabela 43, o corpo de prova do quadrante 3 do tubo 2 apresentou fratura na linha de fusão. Deste modo, a fim de que seja considerado aprovado, submeteu-se a face da fratura aos critérios de aceitação do ensaio Nick-break, conforme o exigido pela norma API 1104 [8], sendo então considerado aprovado. A figura 88 apresenta a região e a face de fratura do corpo de prova do quadrante 3 do tubo 2.

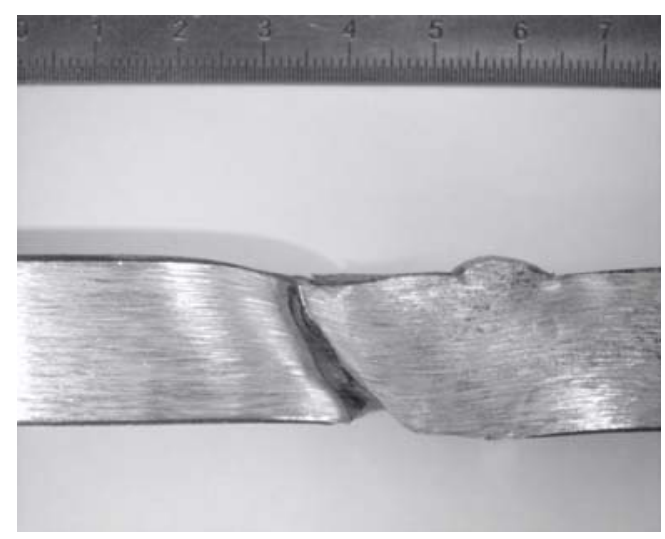

(a)

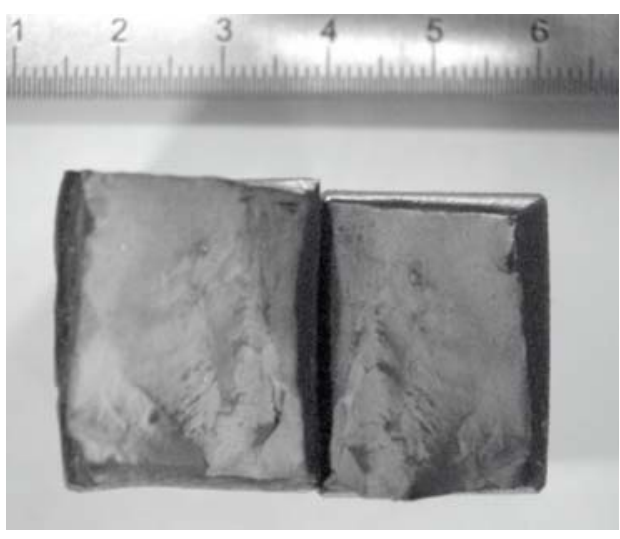

(b)

Figura 88 - Região e face da fratura do corpo de prova de tração do quadrante 3 do tubo 2.

A figura 89 apresenta uma fractografia da face da fratura do mesmo corpo de prova da figura 89 no MEV, onde é possível observar o caráter dúctil da fratura. 


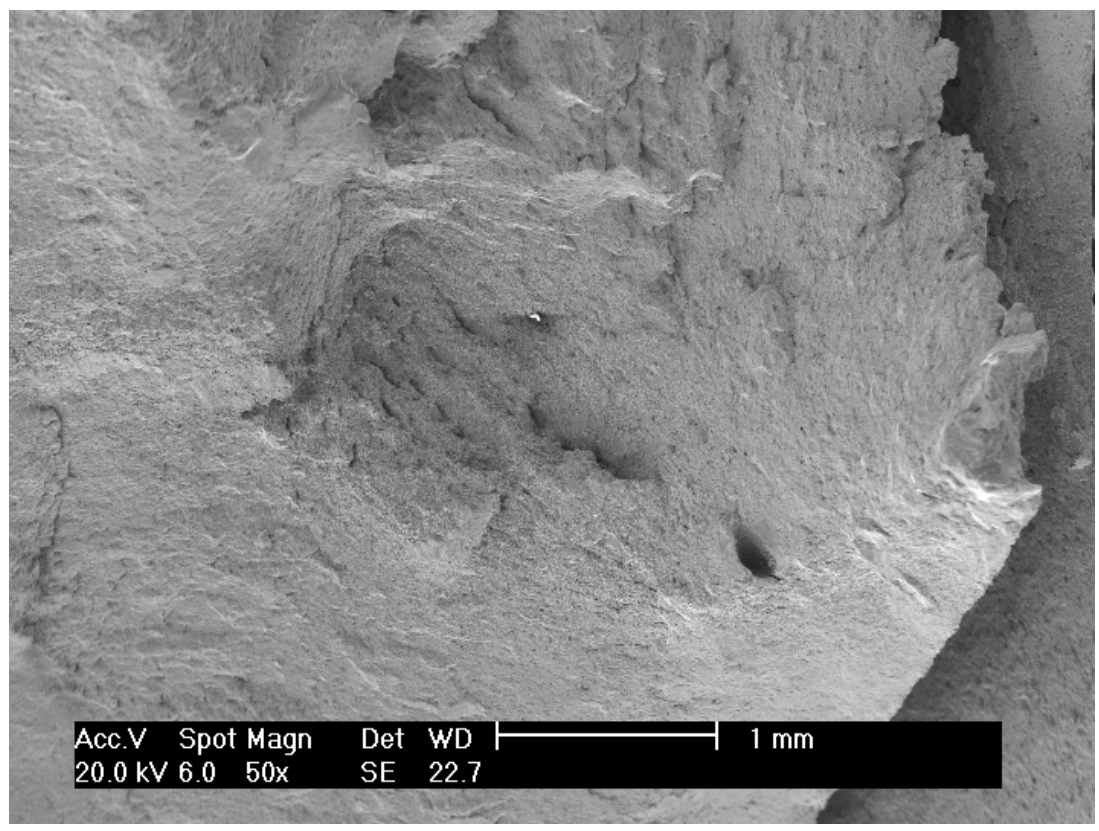

a-) Face da fratura do corpo de prova da figura 88.

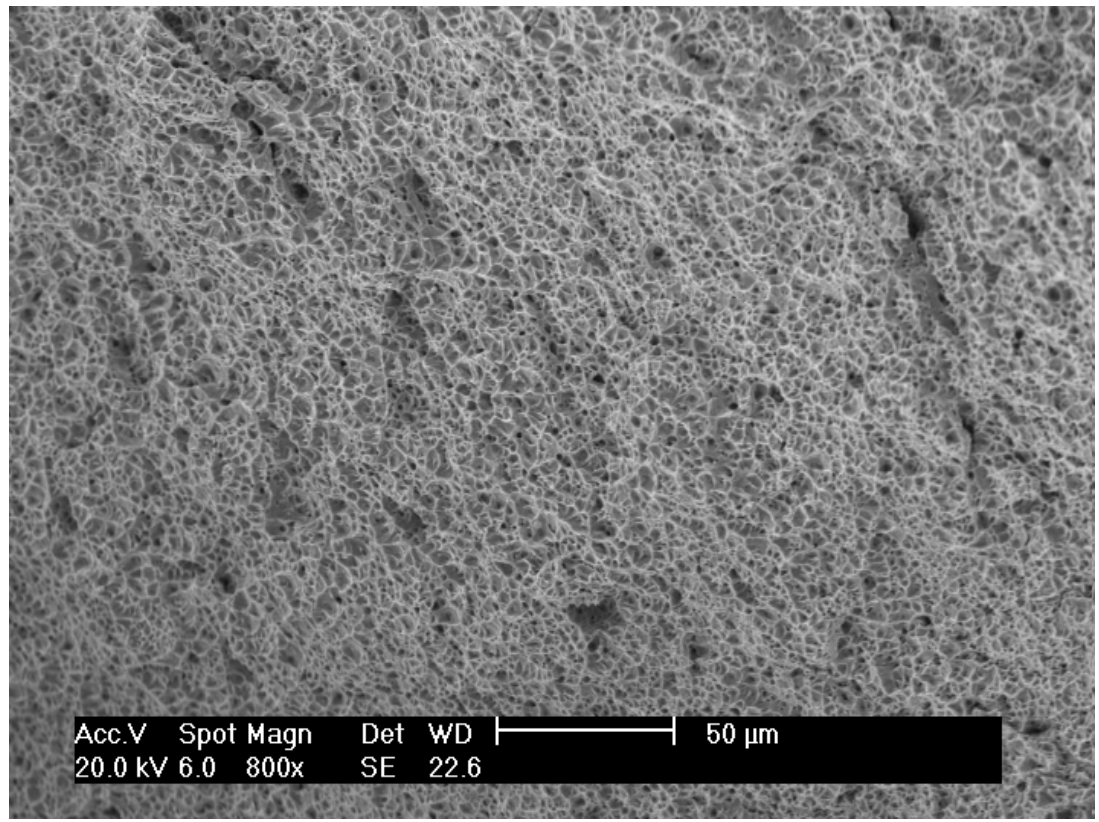

b-) Face da fratura do corpo de prova da figura 88 com maior aumento.

Figura 89 - Região e face da fratura do corpo de prova de tração da figura 86, que rompeu na zona de ligação.

Ainda, pela análise da figura 87, observa-se que o tubo 1 apresentou limite de resistência superior ao do tubo $2 \mathrm{em}$ todos os quadrantes, apesar de 0 consumível utilizado (classificação E91T8-G) apresentar limite de resistência a tração de no mínimo $620 \mathrm{MPa}$, em comparação com o consumível utilizado no tubo 2 (classificação E101T1-GM H8) que apresenta, no mínimo, 690 MPa de 
resistência a tração. O consumível utilizado para o passe de raiz de ambos os tubos apresenta limite de resistência de $550 \mathrm{MPa}$. Analisando-se o certificado dos consumíveis, nota-se que o consumível do E101T1-GM H8 apresenta maior limite de resistência a tração, frente ao consumível E91T8-G, embora o metal de solda apresente resultado ao contrário do valor do certificado. Uma provável explicação para esta diferença pode ser explicado pela concentração de oxigênio, que foi muito maior para o tubo 2 que para o tubo 1. Esta diferença indica uma maior presença de microinclusões no metal de solda com maior teor de oxigênio. Esta maior quantidade de inclusões favorece o mecanismo de fratura dúctil por coalescência de alvéolos, reduzindo o limite de resistência e o alongamento.

\subsubsection{Ensaio de dobramento:}

A tabela 44 apresenta os resultados do ensaio de dobramento realizado nos em todos os quadrantes dos dois tubos.

Tábela 44-Resultados do ensaio de dobramento das juntas soldadas.

\begin{tabular}{|c|c|c|c|c|}
\hline \multicolumn{2}{|c|}{ Quadrante } & Repetição & Fratura: & Resultado \\
\hline \multirow{8}{*}{$\begin{array}{c}\text { Tubo } \\
1\end{array}$} & \multirow{2}{*}{1} & A & Isento de descontinuidades & Aprovado \\
\hline & & B & Abertura de $2,5 \mathrm{~mm}$ na zona de ligação & Aprovado \\
\hline & \multirow{2}{*}{2} & A & Aberturas de 2,1 e $0,8 \mathrm{~mm}$ no metal de solda & Aprovado \\
\hline & & B & Aberturas de 2,$5 ; 2,2$ e $1,4 \mathrm{~mm}$ no metal de solda & Aprovado \\
\hline & \multirow{2}{*}{3} & A & Abertura de 1,6 mm no metal de solda & Aprovado \\
\hline & & B & Abertura de 0,6 mm na zona de ligação & Aprovado \\
\hline & \multirow{2}{*}{4} & A & Abertura de $1,1 \mathrm{~mm}$ no metal de solda & Aprovado \\
\hline & & B & Abertura de $0,5 \mathrm{~mm}$ no metal de solda & Aprovado \\
\hline \multirow{8}{*}{$\begin{array}{c}\text { Tubo } \\
2\end{array}$} & \multirow{2}{*}{1} & A & Isento de descontinuidades & Aprovado \\
\hline & & B & Isento de descontinuidades & Aprovado \\
\hline & \multirow{2}{*}{2} & A & Isento de descontinuidades & Aprovado \\
\hline & & $\mathrm{B}$ & Isento de descontinuidades & Aprovado \\
\hline & \multirow{2}{*}{3} & A & Isento de descontinuidades & Aprovado \\
\hline & & B & Isento de descontinuidades & Aprovado \\
\hline & \multirow{2}{*}{4} & A & Isento de descontinuidades & Aprovado \\
\hline & & $\mathrm{B}$ & Isento de descontinuidades & Aprovado \\
\hline
\end{tabular}

Pela análise da tabela 44, nota-se que os corpos de prova do tubo 1 apresentaram maior quantidade de trincas no corpo de prova, embora dentro 
do critério de aceitação da norma API 1104 [8], sendo considerados aprovados. Uma possível explicação para esta quantidade de trincas nos corpos de prova do tubo 1 reside no fato do maior teor de $\mathrm{Mn}$ e Al do consumível aumentar o limite de resistência e dureza, ocasionando assim menor ductilidade, visto que o tubo 2 não apresentou corpos de prova com trincas de qualquer tamanho.

A figura 90 apresenta alguns corpos de prova com as trincas encontradas no tubo 1 , bem como corpo de prova do tubo 2 , isento de descontinuidades.

(a)
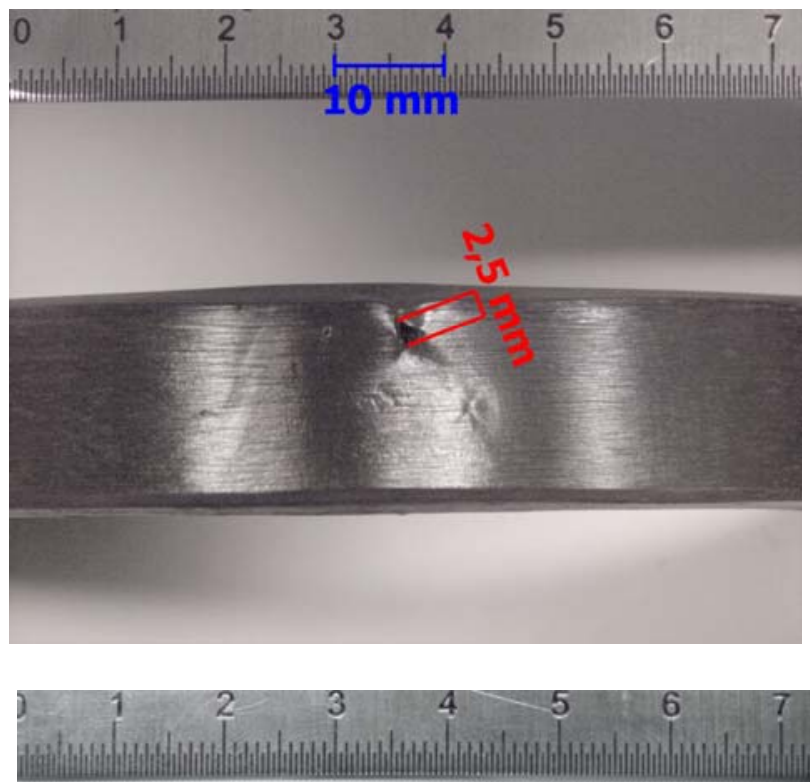

(b)

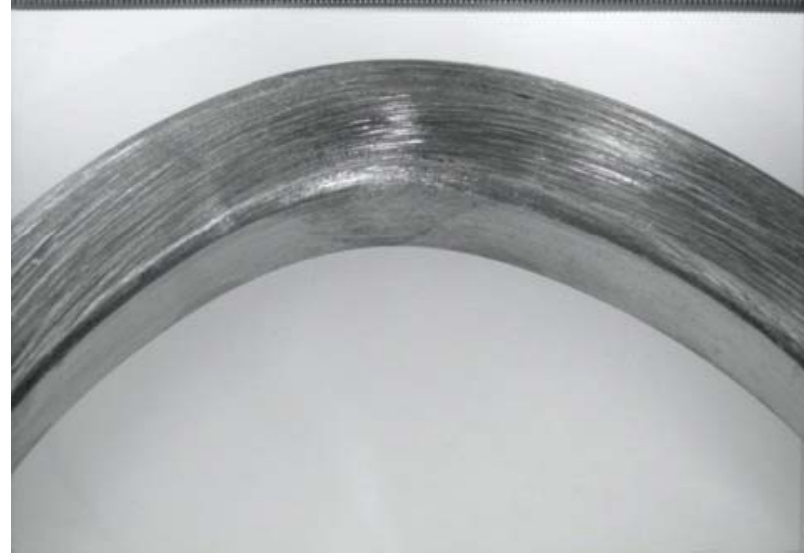

Figura 90 - Exemplos de corpos de prova do ensaio de dobramento. (a) Corpo de prova do tubo 1, quadrante 1 apresentando trinca de $2,5 \mathrm{~mm}$ de comprimento; (b) Corpo de prova de dobramento do tubo 2 , quadrante 1 , isento de descontinuidades. 


\subsubsection{Ensaio Nick-break:}

A tabela 45 apresenta os resultados do ensaio de Nick-Break em todos os quadrantes dos dois tubos.

Tábela 45- Resultado do ensaio de Nick-Break.

\begin{tabular}{|c|c|c|c|}
\hline \multicolumn{2}{|c|}{ Quadrante } & Fratura & Resultado \\
\hline \multirow{3}{*}{ Tubo 1 } & 1 & Isentode descontinuidades & Aprovado \\
\cline { 3 - 4 } & 2 & Falta de fusão na raiz & Reprovado \\
\cline { 3 - 4 } & 3 & Isentode descontinuidades & Aprovado \\
\cline { 3 - 4 } & 4 & Isentode descontinuidades & Aprovado \\
\hline \multirow{4}{*}{ Tubo 2 } & 1 & Isentode descontinuidades & Aprovado \\
\cline { 3 - 4 } & 2 & Isentode descontinuidades & Aprovado \\
\cline { 3 - 4 } & 3 & Isentode descontinuidades & Aprovado \\
\cline { 3 - 4 } & 4 & Isentode descontinuidades & Aprovado \\
\hline
\end{tabular}

Pela análise da tabela 45, nota-se que todos os corpos de prova foram aprovados sem a presença de descontinuidades, exceto o quadrante 2 do tubo 1 que apresentou falta de fusão no passe de raiz. Esta falta de fusão foi causada por uma interrupção na soldagem e reinício da mesma, conforme pode ser visto na figura 91. A fim de caracterizar a região onde ocorreu esta descontinuidade, foi realizada a análise através de microscopia eletrônica de varredura (figura 92) e fractografia (figura 93), bem como análise por EDS dos precipitados encontrados na região de falta de fusão. Através desta análise houve a confirmação de que se tratava de uma região onde ocorreu falta de fusão. Esta descontinuidade encontrada demonstra o quão ruim é a interrupção da soldagem e importante o correto preparo da região antes do reinício da soldagem, além de um treinamento adequado do soldador com o processo MAG-TC. Por motivos alheios à vontade do soldador, a soldagem teve de ser momentaneamente interrompida. Por coincidência, o corpo de prova foi retirado desta região. 


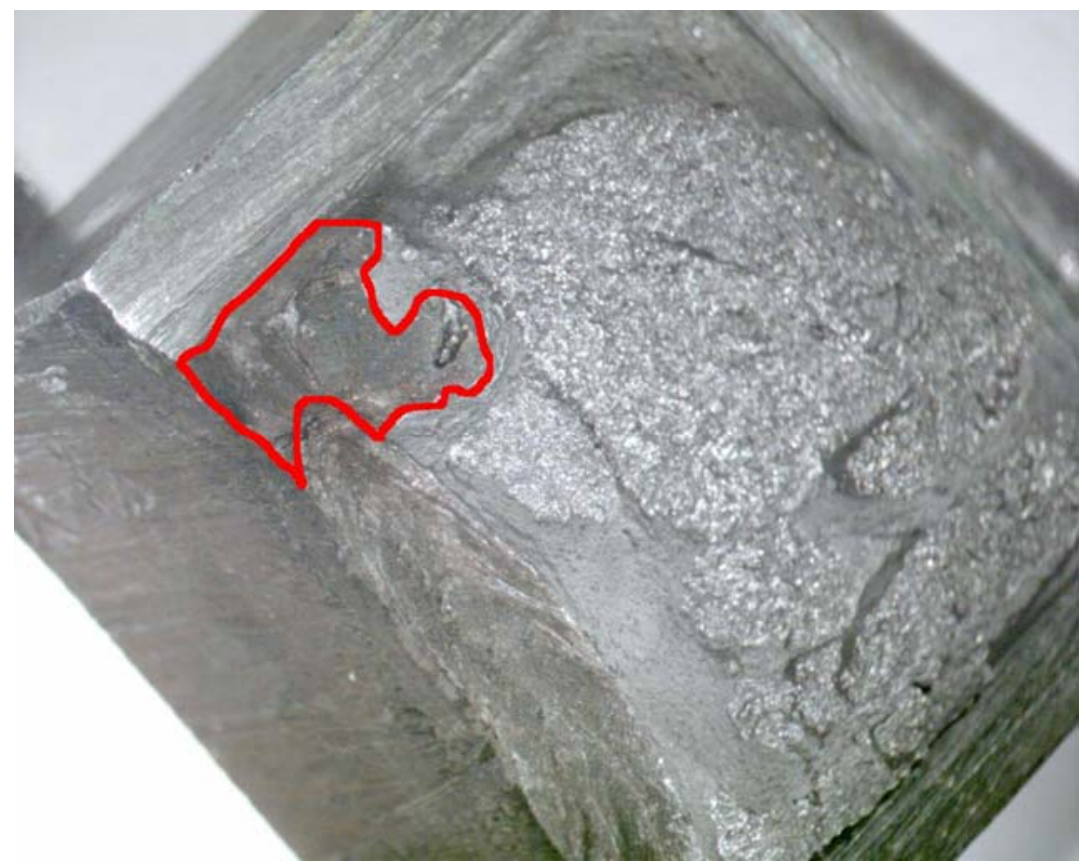

Figura 91 - Região com falta de fusão no passe de raiz no quadrante 2 do tubo 1, mostrando o cordão interrompido e o cordão de reinício.

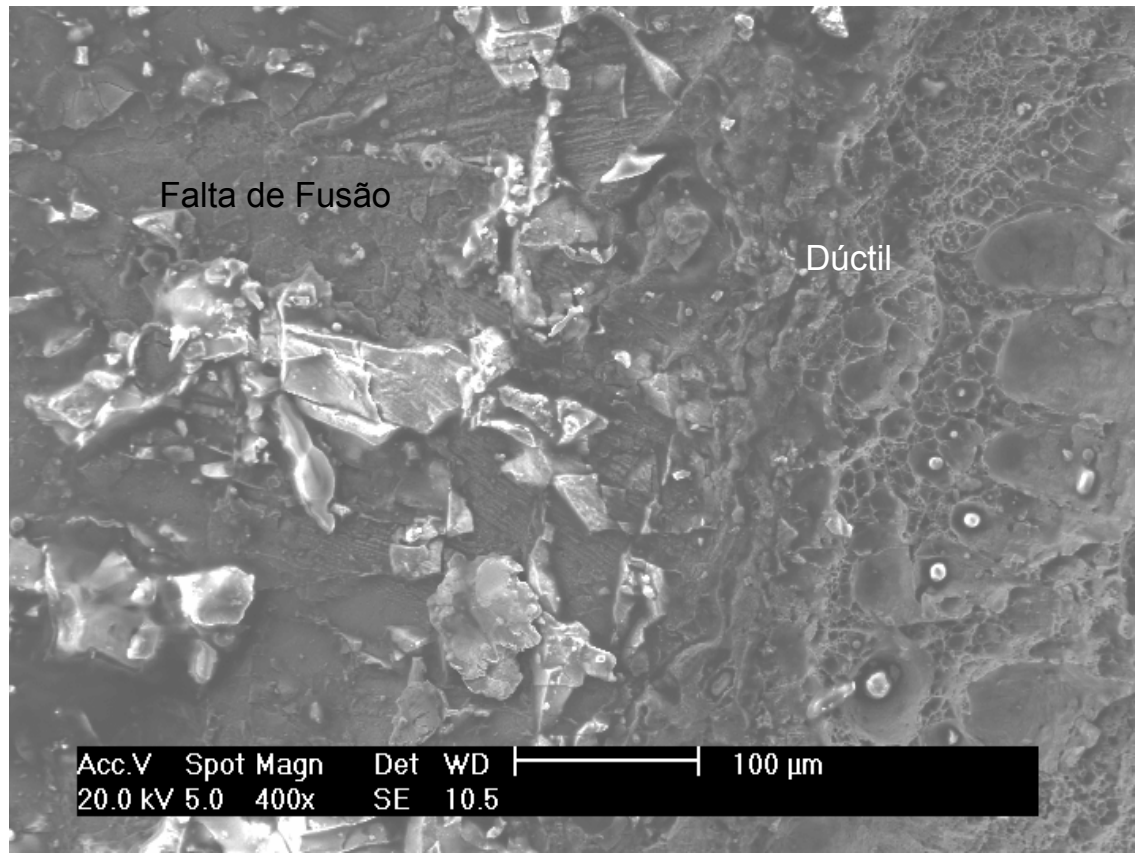

Figura 92 - Região com falta de fusão no passe de raiz no quadrante 2 do tubo 1 , mostrando interface entre a falta de fusão a região de início de fratura dúctil.

Para melhor visualizar a topografia da fratura foi montada a figura 93 onde se percebe a topografia da fratura exatamente na região de transição entre a falta de fusão e o início da fratura dúctil. 


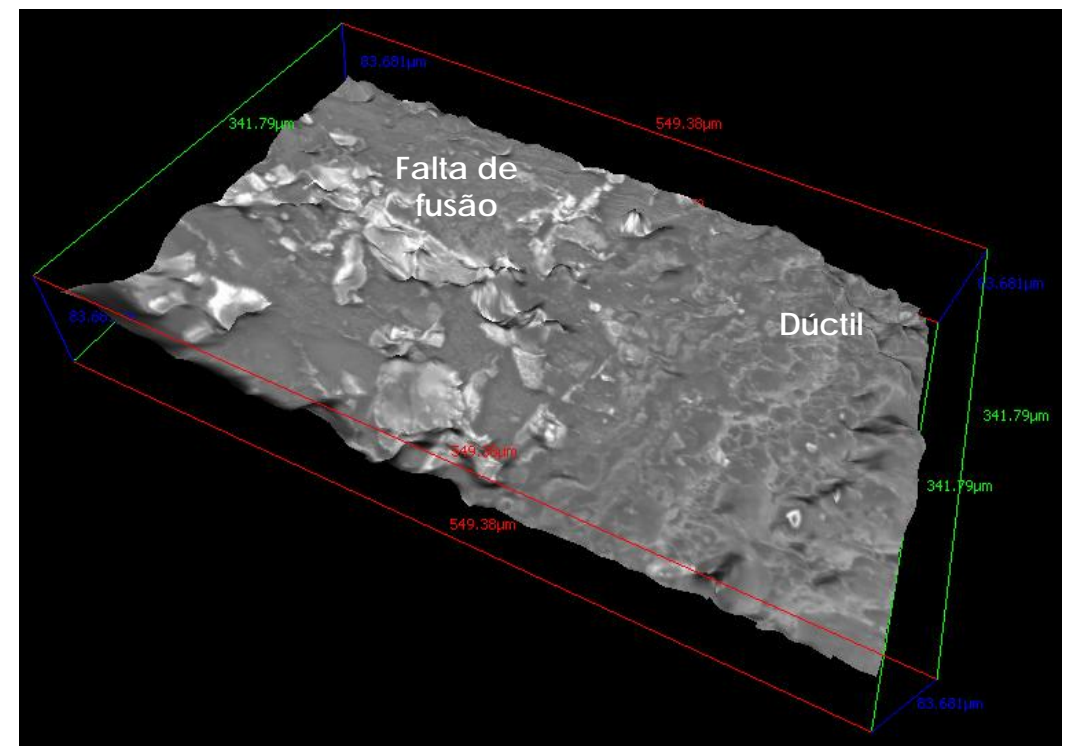

Figura 93- Montagem em 3D apresentando a fractografia da região com falta de fusão no passe de raiz no quadrante 2 do tubo 1 , mostrando interface entre a falta de fusão a região de fratura dúctil.

A figura 94 mostra a análise por dispersão de energia de uma região clara da falta de fusão.

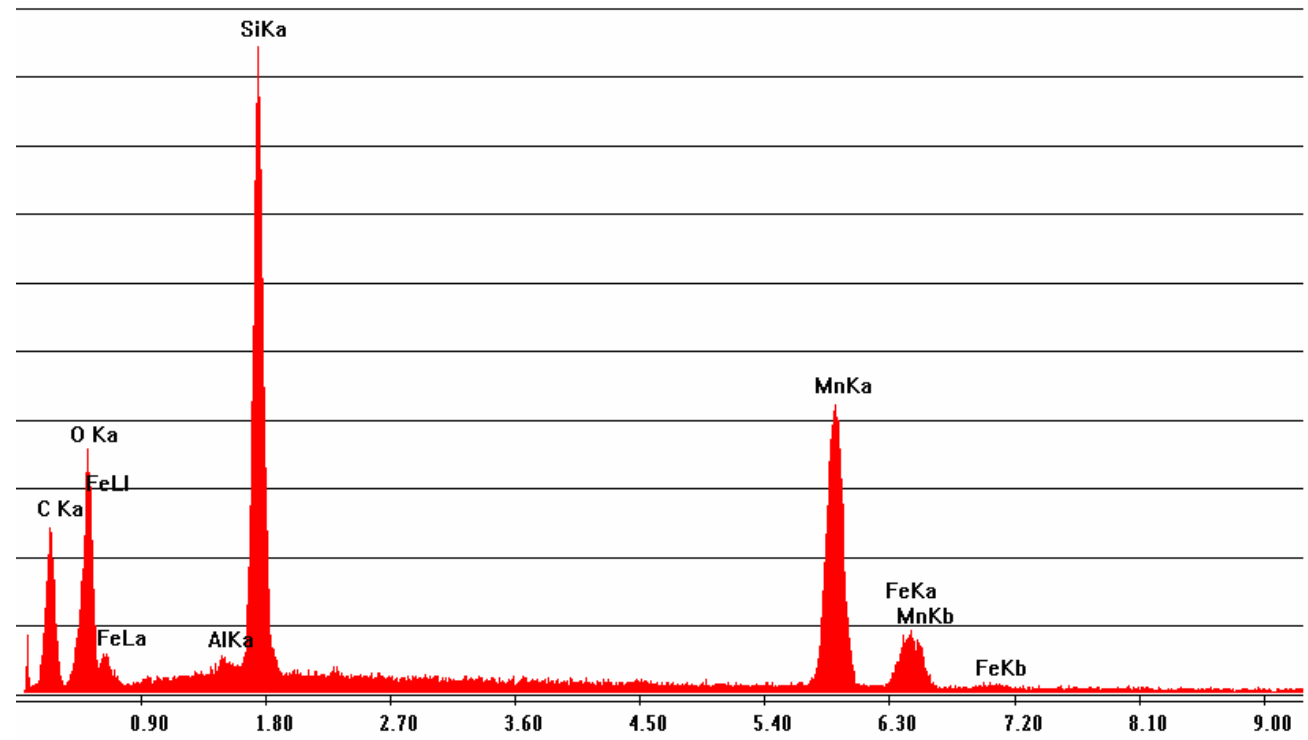

Figura 94 - Análise por EDS da região clara na falta de fusão da figura acima. 
A análise da composição química mostra a presença de óxidos de silício, manganês, alumínio e ferro, caracterizando uma inclusão de escória.

As figuras 95 e 96 apresentam fotos das faces da fratura dos corpos de prova de Nick-break fotografadas com lupa estereoscópica, nas quais pode-se observar que em todos os quadrantes há uma clara distinção do comportamento das fraturas na região da raiz e do enchimento. Percebeu-se que para os quadrantes 1,2 e 4 do tubo 1 e o 2 e 4 do tubo 2 , o comportamento da fratura na região da raiz foi predominantemente frágil, enquanto que a região do enchimento foi tipicamente dúctil. Para o corpo de prova do quadrante 3 do tubo 1 e os 1 e 3 do tubo 2, o comportamento na região da raiz foi predominantemente dúctil com a presença de regiões frágeis.
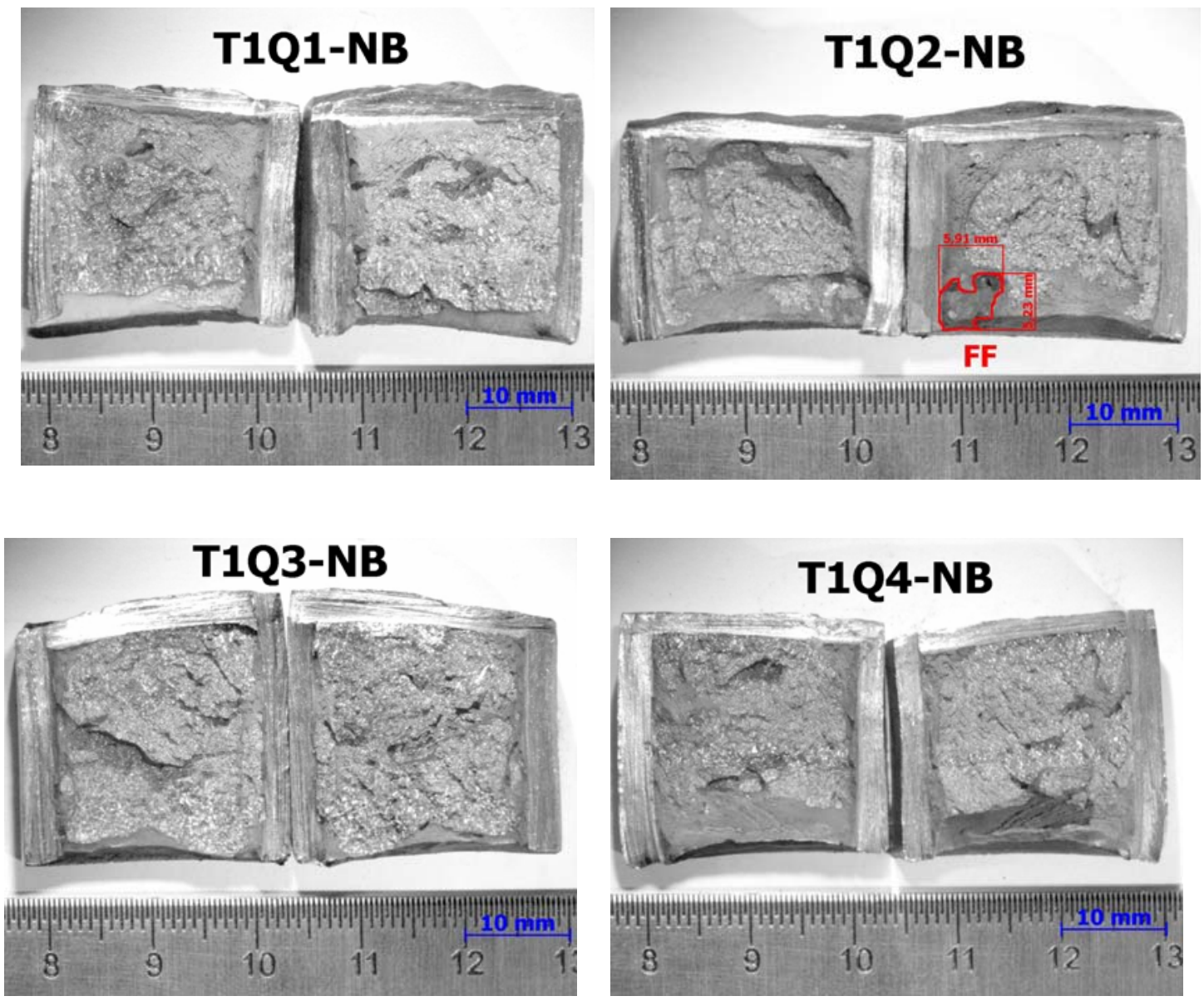

Figura 95- Face da fratura dos corpos de prova do ensaio nick-break para o tubo 1, obtidas em lupa estereoscópica. 

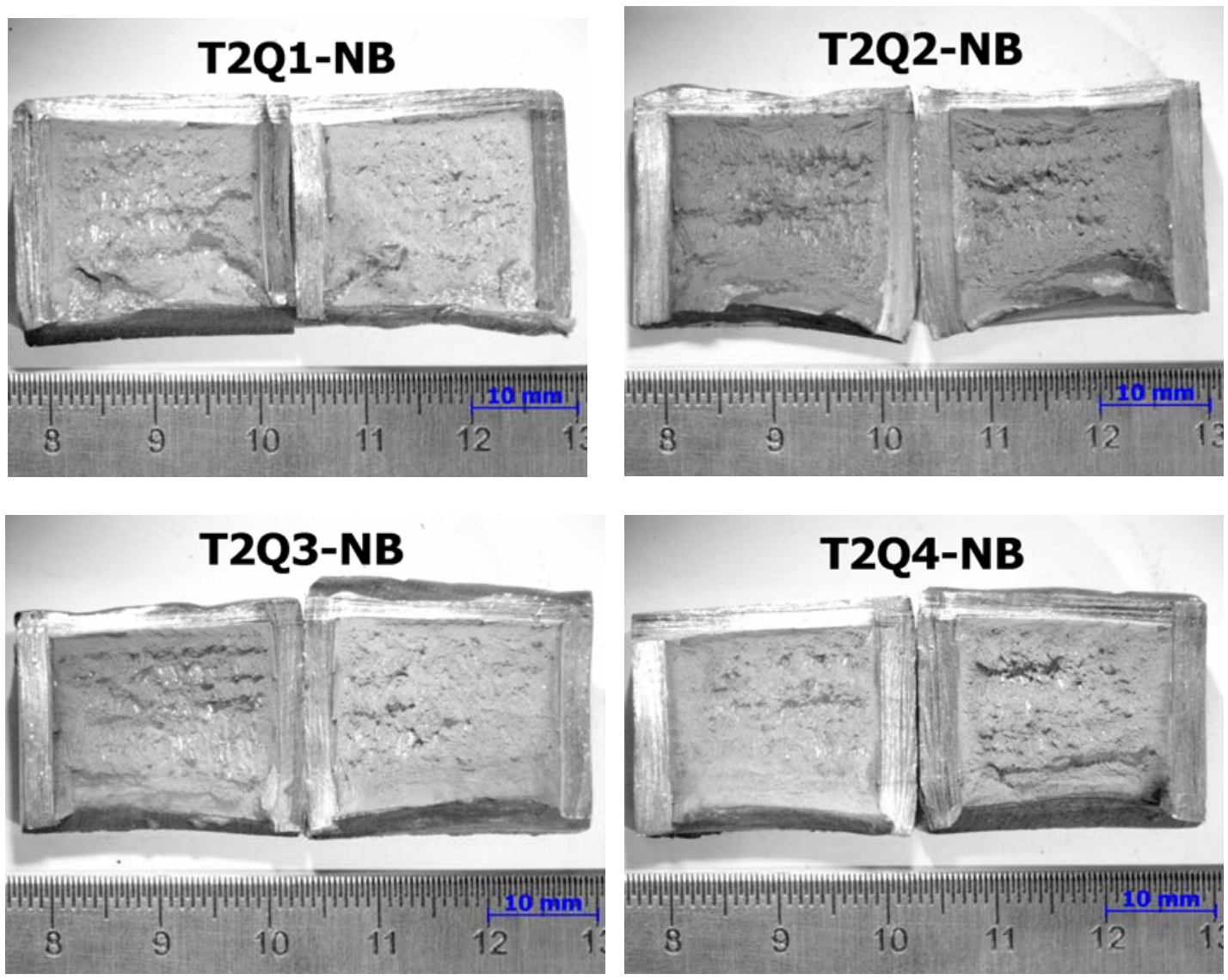

Figura 96 - Face da fratura dos corpos de prova do ensaio nick-break para o tubo 2, obtidas em lupa estereoscópica.

A figura 97 apresenta uma fractografia obtida no MEV mostrando regiões com fratura frágil (a) e regiões com fratura dúctil (b) na superfície de corpos-de-prova nick-break.

Conforme apresentado anteriormente, a microestrutura dos passes de enchimento do tubo 1 possui resistência elevada. O ensaio de nick-break é do tipo de um ensaio de tração com o corpo de prova entalhado em algumas faces. Estes entalhes criam concentrações de tensão que acabam por promover fraturas frágeis em corpos-de-prova com resistência maior.

As figura 98 e 99 apresentam uma montagem 3D do enchimento e da raiz do corpo de prova do quadrante 2 , apresentando fratura com caráter frágil e dúctil, respectivamente. Nas topografias coloridas, os tons tendendo para o vermelho são vales enquanto que os tons tendendo para o amarelo representam picos na foto. 

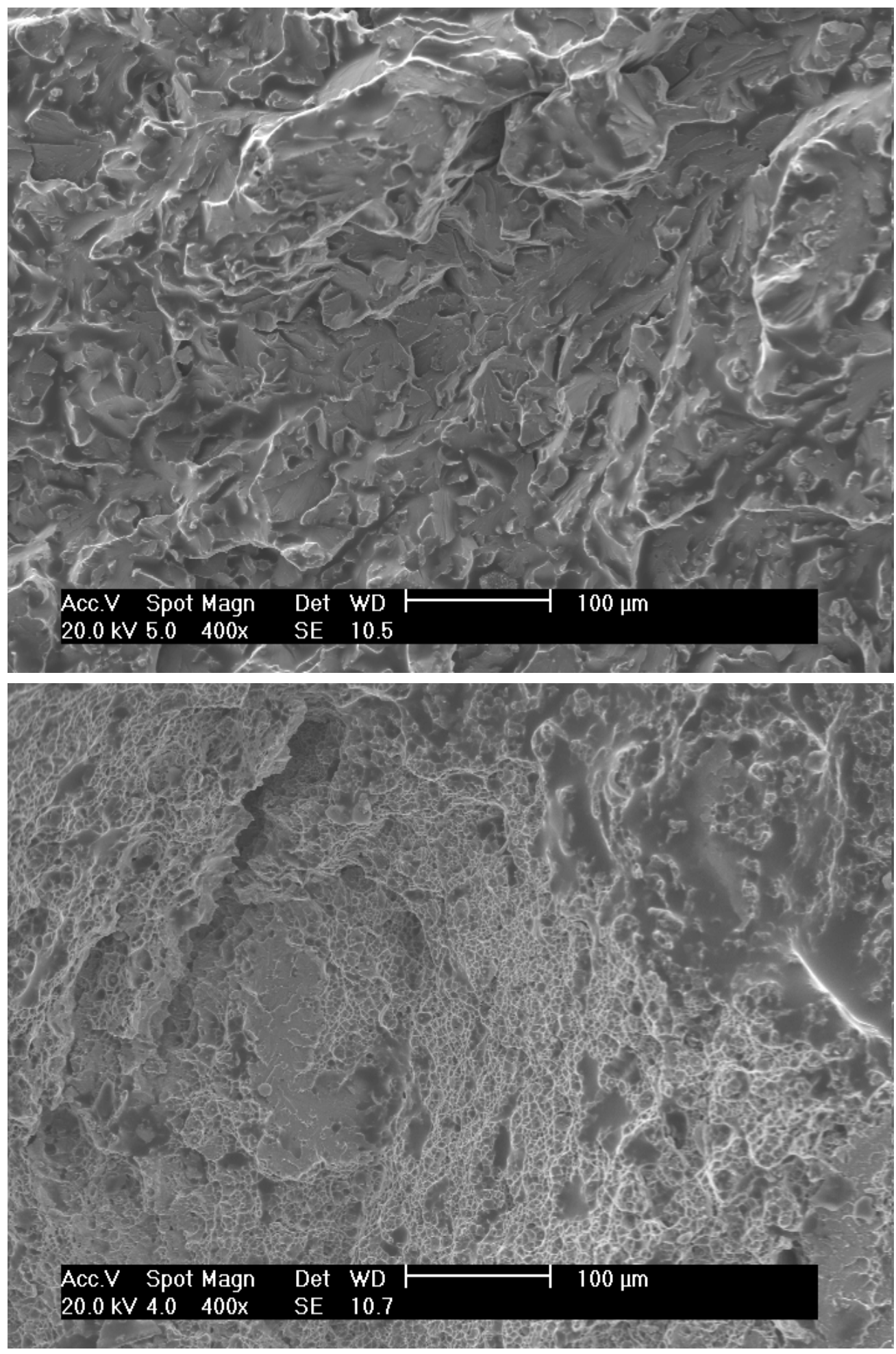

Figura 97- Face da fratura dos corpos de prova do ensaio nick-break para o tubo 1, obtidas em MEV. (a) enchimento; (b) raiz. 

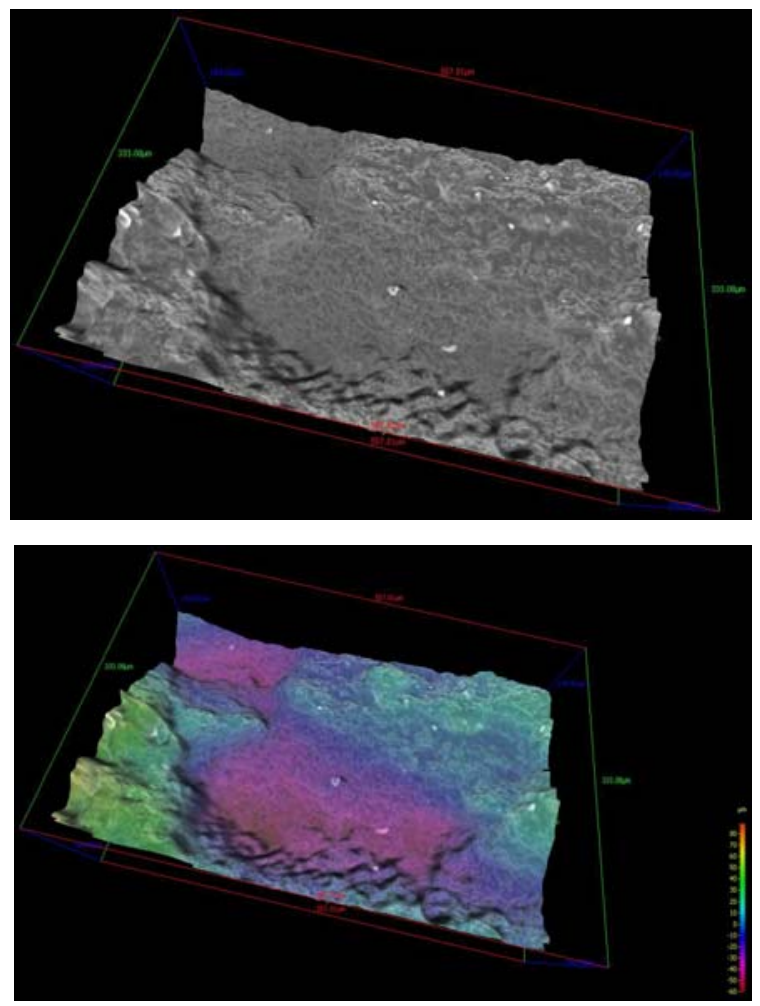

Figura 98- Montagem em 3D apresentando a fractografia da região de fratura do corpo de prova T1Q2-NB do tubo 1, na região do enchimento, apresentando caráter dúctil.
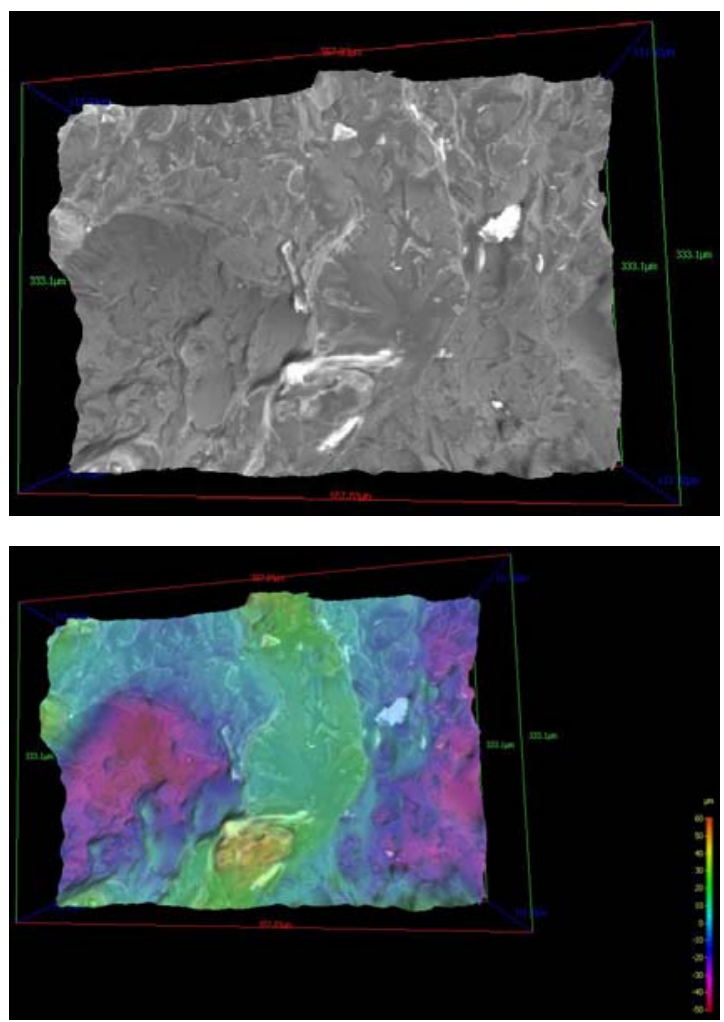

Figura 99- Montagem em 3D apresentando a fractografia da região de fratura do corpo de prova T1Q2-NB do tubo 1, na região da raiz, apresentando caráter frágil. 
5.4.5 Ensaio de impacto:

\subsubsection{Energia absorvida:}

A tabela 46 mostra os resultados obtidos do ensaio Charpy $\mathrm{V}$ a $0^{\circ} \mathrm{C}$. $\mathrm{A}$ figura 100 apresenta os resultados da energia absorvida média em relação às regiões do corpo de prova e aos quadrantes para o tubo 1. Os valores foram comparados com a energia média obtida para o metal de base.

Tabela 46- Resultado do ensaio de impacto Charpy V a $0^{\circ} \mathrm{C}$.

\begin{tabular}{|c|c|c|c|c|c|c|c|c|c|c|c|}
\hline & \multicolumn{5}{|c|}{ Energia Absorvida $(\mathrm{J})$} & \multicolumn{5}{|c|}{ Expansão lateral (\%) } \\
\hline & & 1 & 2 & 3 & Média & Desv. Pad. & 1 & 2 & 3 & Média & Desv. Pad. \\
\hline \multirow{3}{*}{ T1Q1 } & Raiz & 47 & 60 & 93 & 66,7 & 23,7 & 7,3 & 7,6 & 12,7 & 9,2 & 3,0 \\
\hline & Ench. & 109 & 78 & 111 & 99,3 & 18,5 & 14,7 & 10,9 & 14,8 & 13,5 & 2,2 \\
\hline & ZTA & 231 & 244 & 299 & 258,0 & 36,1 & 20,7 & 20,8 & 19,1 & 20,2 & 0,9 \\
\hline \multirow{3}{*}{ T1Q2 } & Raiz & 38 & 61 & 91 & 63,3 & 26,6 & 1,4 & 8,8 & 7,4 & 5,9 & 3,9 \\
\hline & Ench. & 122 & 122 & 116 & 120,0 & 3,5 & 15,8 & 5,9 & 16,5 & 12,7 & 5,9 \\
\hline & ZTA & 241 & 267 & 111 & 206,3 & 83,6 & 13,5 & 18,4 & 11,8 & 14,6 & 3,4 \\
\hline \multirow{3}{*}{ T1Q3 } & Raiz & 76 & 84 & 67 & 75,7 & 8,5 & 10,0 & 11,9 & 2,5 & 8,1 & 5,0 \\
\hline & Ench. & 160 & 129 & 116 & 135,0 & 22,6 & 17,5 & 14,3 & 14,2 & 15,3 & 1,9 \\
\hline & ZTA & 241 & 238 & 221 & 233,3 & 10,8 & 19,6 & 21,7 & 16,2 & 19,2 & 2,8 \\
\hline \multirow{3}{*}{ T1Q4 } & Raiz & 75 & 58 & 56 & 63,0 & 10,4 & 10,1 & 8,1 & 8,7 & 9,0 & 1,0 \\
\hline & Ench. & 119 & 124 & 115 & 119,3 & 4,5 & 13,8 & 13,8 & 14,4 & 14,0 & 0,3 \\
\hline & ZTA & 278 & 245 & 299 & 274,0 & 27,2 & 17,6 & 18,2 & 23,9 & 19,9 & 3,5 \\
\hline \multirow{3}{*}{ T2Q1 } & Raiz & 82 & 95 & \begin{tabular}{|l|}
107 \\
\end{tabular} & 94,7 & 12,5 & 10,5 & 10,7 & 9,3 & 10,2 & 0,8 \\
\hline & Ench. & 121 & 120 & 115 & 118,7 & 3,2 & 11,3 & 15,2 & 14,0 & 13,5 & 2,0 \\
\hline & ZTA & 211 & 209 & 214 & 211,3 & 2,5 & 19,2 & 16,4 & 16,6 & 17,4 & 1,5 \\
\hline \multirow{3}{*}{ T2Q2 } & Raiz & 110 & 109 & \begin{tabular}{|l|}
102 \\
\end{tabular} & 107,0 & 4,4 & 13,3 & 11,5 & 11,0 & 11,9 & 1,2 \\
\hline & Ench. & 131 & 124 & 129 & 128,0 & 3,6 & 13,7 & 13,6 & 13,4 & 13,6 & 0,1 \\
\hline & ZTA & 115 & 173 & 214 & 167,3 & 49,7 & 19,0 & 10,1 & 17,3 & 15,5 & 4,7 \\
\hline \multirow{3}{*}{ T2Q3 } & Raiz & 128 & 122 & 96 & 115,3 & 17,0 & 14,4 & 12,1 & 10,8 & 12,5 & 1,8 \\
\hline & Ench. & 140 & 121 & 137 & 132,7 & 10,2 & 14,6 & 16,7 & 13,9 & 15,1 & 1,5 \\
\hline & ZTA & 178 & 230 & 215 & \begin{tabular}{|l|}
207,7 \\
\end{tabular} & 26,8 & 17,4 & 18,9 & 13,1 & 16,5 & 3,0 \\
\hline \multirow{3}{*}{ T2Q4 } & Raiz & 88 & 104 & 101 & 97,7 & 8,5 & 11,5 & 10,6 & 11,6 & 11,2 & 0,5 \\
\hline & Ench. & 119 & 120 & 121 & 120,0 & 1,0 & 11,5 & 10,9 & 14,3 & 12,2 & 1,8 \\
\hline & ZTA & 269 & 206 & 225 & 233,3 & 32,3 & 18,0 & 18,5 & 17,4 & 18,0 & 0,6 \\
\hline \multicolumn{2}{|l|}{ MB } & 206 & 215 & 191 & 204,0 & 12,1 & 17,2 & 17.9 & 17.5 & 17.5 & 0,4 \\
\hline
\end{tabular}

A figura 101 apresenta a superfície da fratura de um corpo-de-prova do metal base. Observa-se que seu aspecto é tipicamente dúctil. 


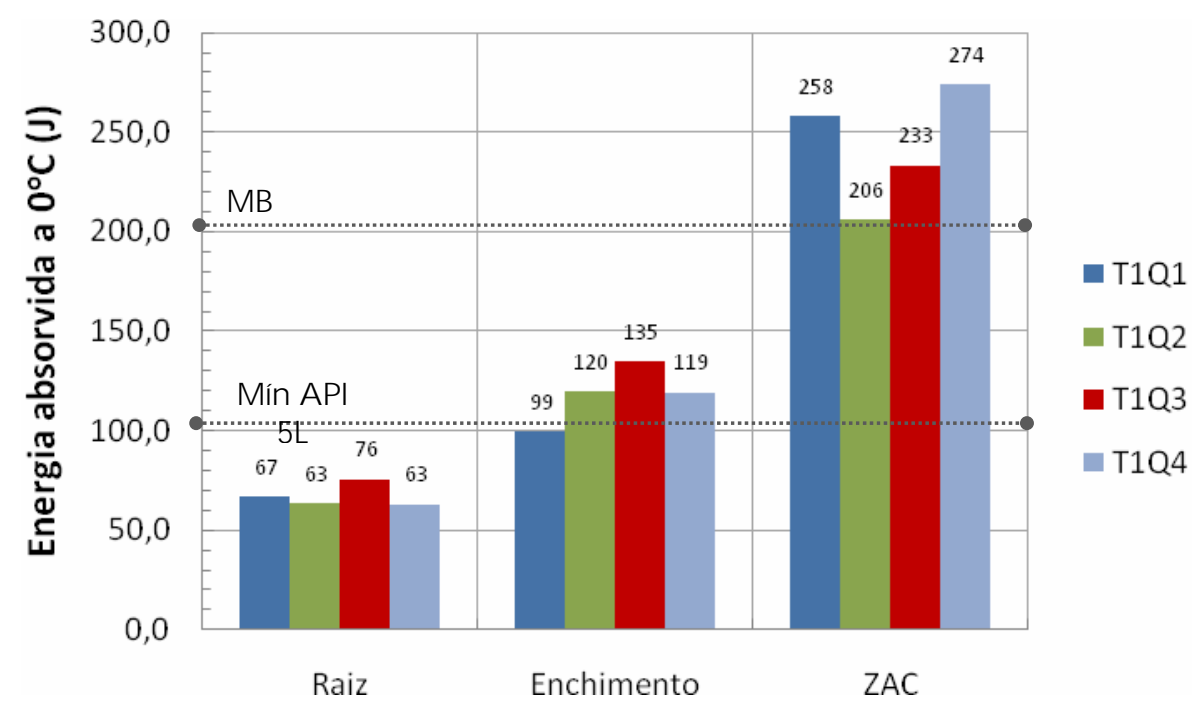

Figura 100 - Energia absorvida pelas diferentes regiões da junta soldada do tubo 1, nos quatro quadrantes

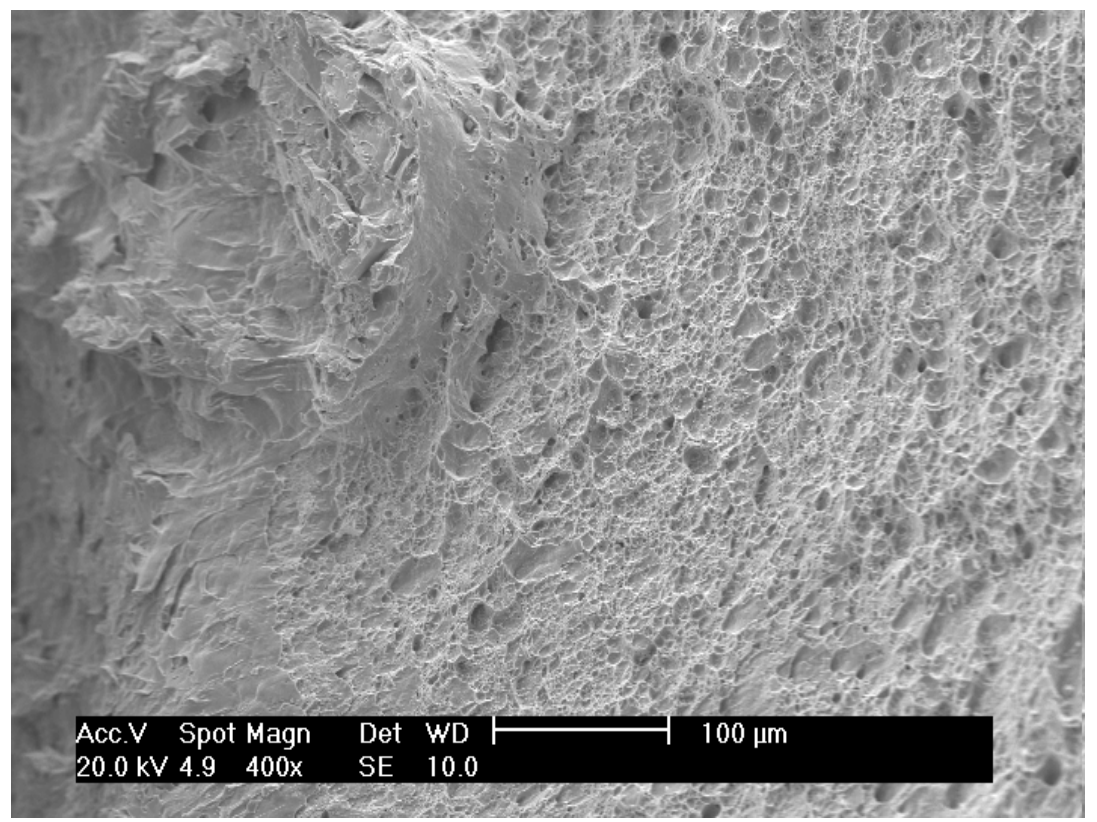

Figura 101 - Face da fratura de corpo de prova do ensaio de impacto do metal base, obtida com o auxílio de microscópio eletrônico de varredura.

Pela análise da figura 100, observa-se que houve grande variação entre a energia absorvida e a região ensaiada. Para todos os quadrantes no passe de raiz a energia absorvida ficou abaixo do mínimo especificado pela norma API 5L [9] para o sentido longitudinal do metal de base $\left(101 \mathrm{~J}\right.$ a $\left.0^{\circ} \mathrm{C}\right)$ e bem distante da média obtida pelo metal de base. O certificado do consumível utilizado nos passes de raiz apresenta energia absorvida de $101 \mathrm{~J}$ a $-29^{\circ} \mathrm{C}$, logo 
a $0^{\circ} \mathrm{C}$ esperava-se encontrar um maior valor de energia absorvida, o que não foi encontrado. Uma das possíveis razões para este comportamento reside na maior taxa de resfriamento obtida e no maior teor de Mn presente no metal de solda da raiz, o que provocou um aumento na temperabilidade, que somado a maior taxa de resfriamento provocou este queda na tenacidade. A figura 102 apresenta a face da fratura do corpo de prova do quadrante 2 do tubo 1 na região da raiz, onde pode notar $\mathrm{o}$ aspecto da superfície que sugere $\mathrm{o}$ comportamento frágil.

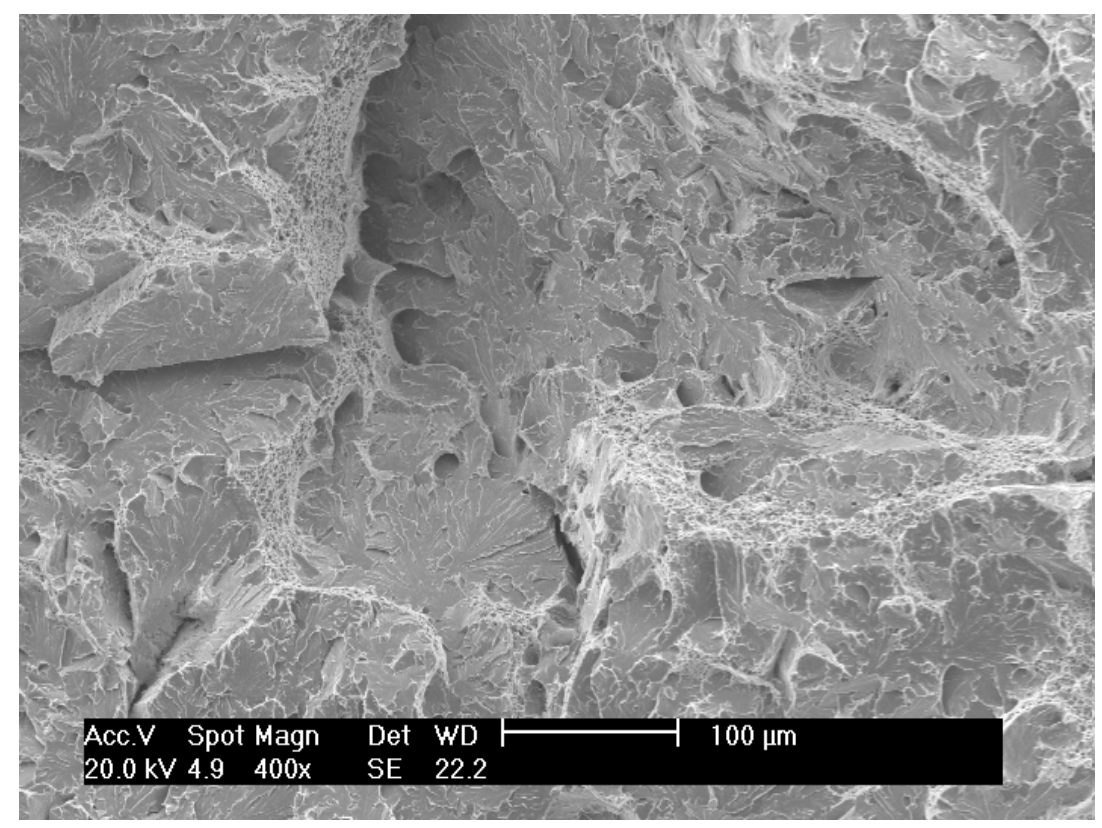

Figura 102- Face da fratura dos corpos de prova do ensaio de impacto na região da raiz do quadrante 2 do tubo 1, obtidas com o auxílio de microscópio eletrônico de varredura, apresentando caráter frágil.

Ainda, pela análise da figura 100, é possível notar que os valores da energia absorvida pela região dos passes de enchimento situaram-se entre os valores da raiz e da ZAC, atingindo em alguns quadrantes o mínimo requerido pela norma API 5L [9] e situando-se abaixo da média do metal de base. Uma possível causa para este comportamento é a menor velocidade de resfriamento encontrada em relação ao passe de raiz, prevenindo a formação de maior quantidade de microestruturas frágeis. A figura 103 apresenta a face da fratura do corpo de prova do quadrante 2 do tubo 1 obtida através de microscopia eletrônica de varredura, onde é possível observar a mudança do comportamento da fratura de predominantemente frágil para dúctil-frágil. 


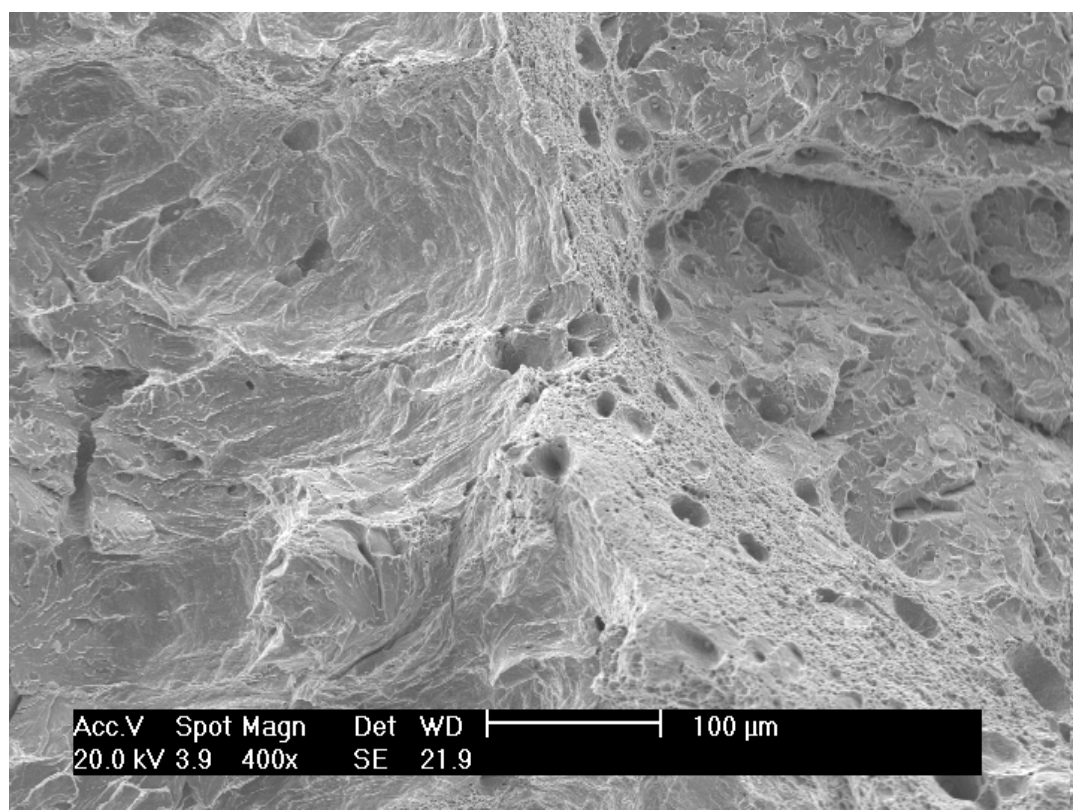

Figura 103- Face da fratura do corpo de prova do quadrante 2 do tubo 1 na região do enchimento, obtidas através de microscopia eletrônica de varredura, apresentando caráter dúctil-frágil.

Observando-se os valores de energia absorvida da ZAC nota-se que estas foram as maiores energias absorvidas entre todas as regiões da junta soldada, ficando acima da energia absorvida mínima da norma API 5L[9] e também acima da média do metal de base. A causa deste fenômeno é que a ZAC possui maior refino de grão. A figura 104 apresenta a face da fratura do corpo de prova do quadrante 2 do tubo 1, obtida através de microscopia eletrônica de varredura apresentando fratura com comportamento dúctil-frágil.

A fim de verificar a propagação da fratura no ensaio Charpy $V$ da ZAC foi realizada uma montagem das micrografias das regiões representadas esquematicamente pelas figuras 105(a) (perpendicular ao entalhe) e figura 105(b) (transversal ao entalhe). A figura 106 apresenta um esquema da montagem da microestrutura na região da fratura do corpo de prova $\mathrm{n}^{\circ} 2$ do quadrante 4 do tubo 1 , em sentido perpendicular com o entalhe do corpo de prova, onde nota-se que a propagação da fratura ocorreu em direção ao metal de base. Logo, pode-se observar que o metal de base possui menor tenacidade em comparação com a ZAC. A figura 107 apresenta uma montagem da microestrutura na região de fratura do mesmo corpo de prova da figura 106, em sentido paralelo ao entalhe. A fratura propagou tanto na ZAC como na zona fundida dos cordões de solda. Como estas regiões foram submetidas a diversos ciclos térmicos, a dureza do MA pode ter reduzido ou 
mesmo a trinca propagou em regiões com tamanho de grão pequeno (região intercrítica).

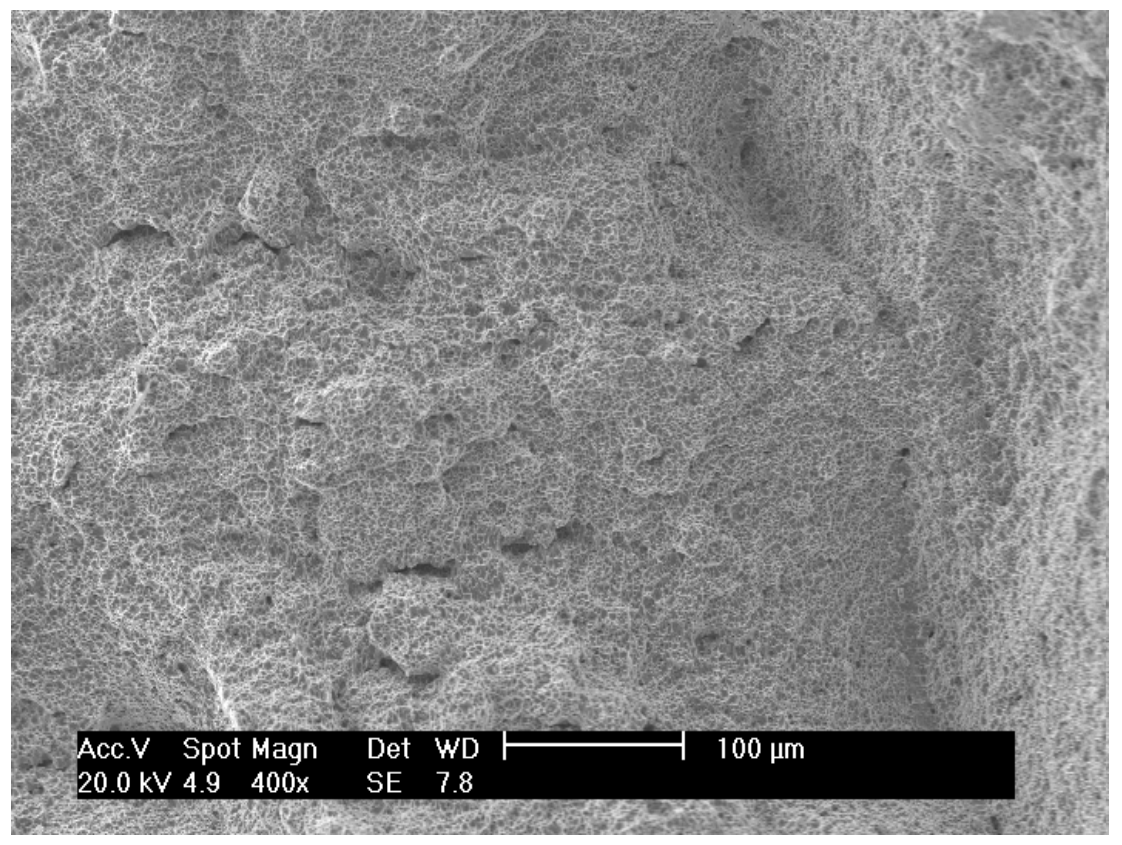

Figura 104- Face da fratura do corpo de prova do quadrante 2 do tubo 1 obtidas através de microscopia eletrônica de varredura, apresentando fratura com comportamento dúctil na ZAC.

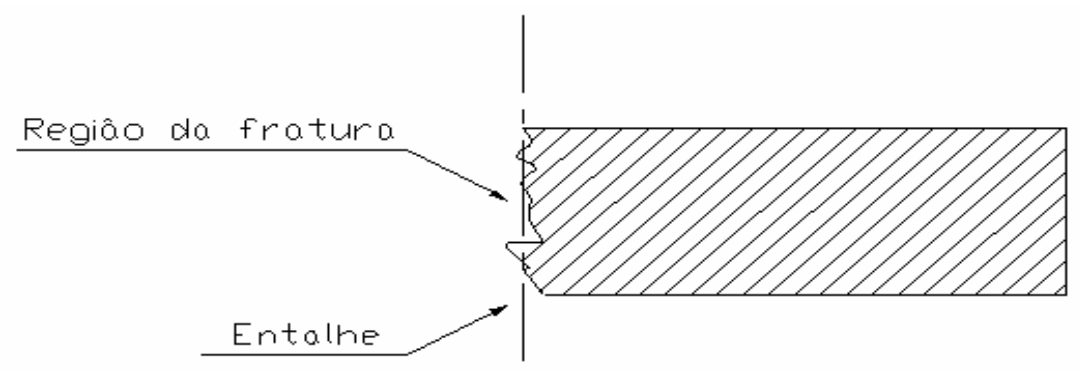

(a)

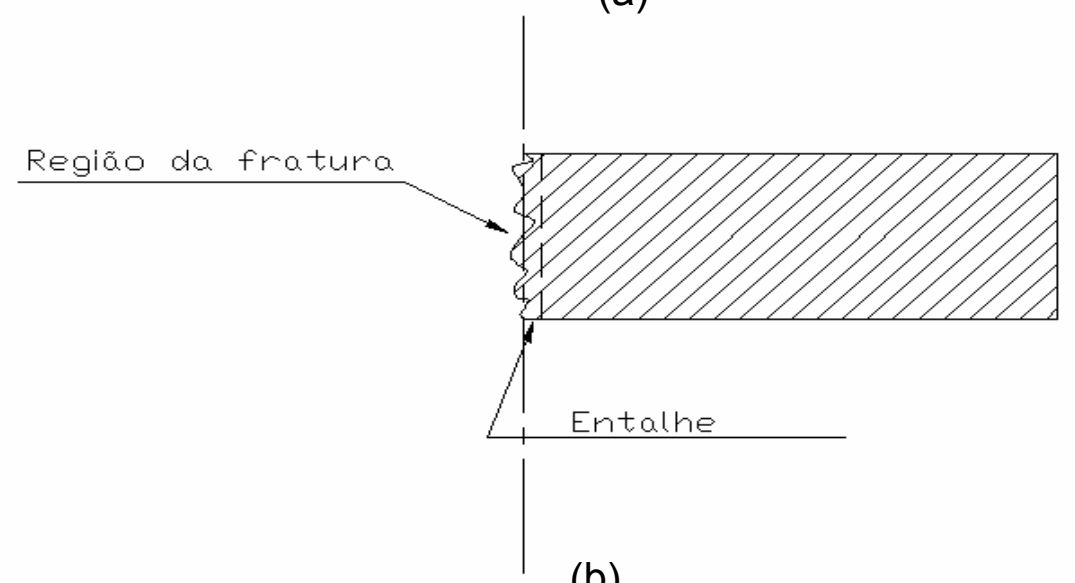

(b)

Figura 105 - Região de obtenção das micrografias da fratura do corpo de prova do quadrante 4 do tubo 1 . Sentido perpendicular ao entalhe (a), e transversal (b). 


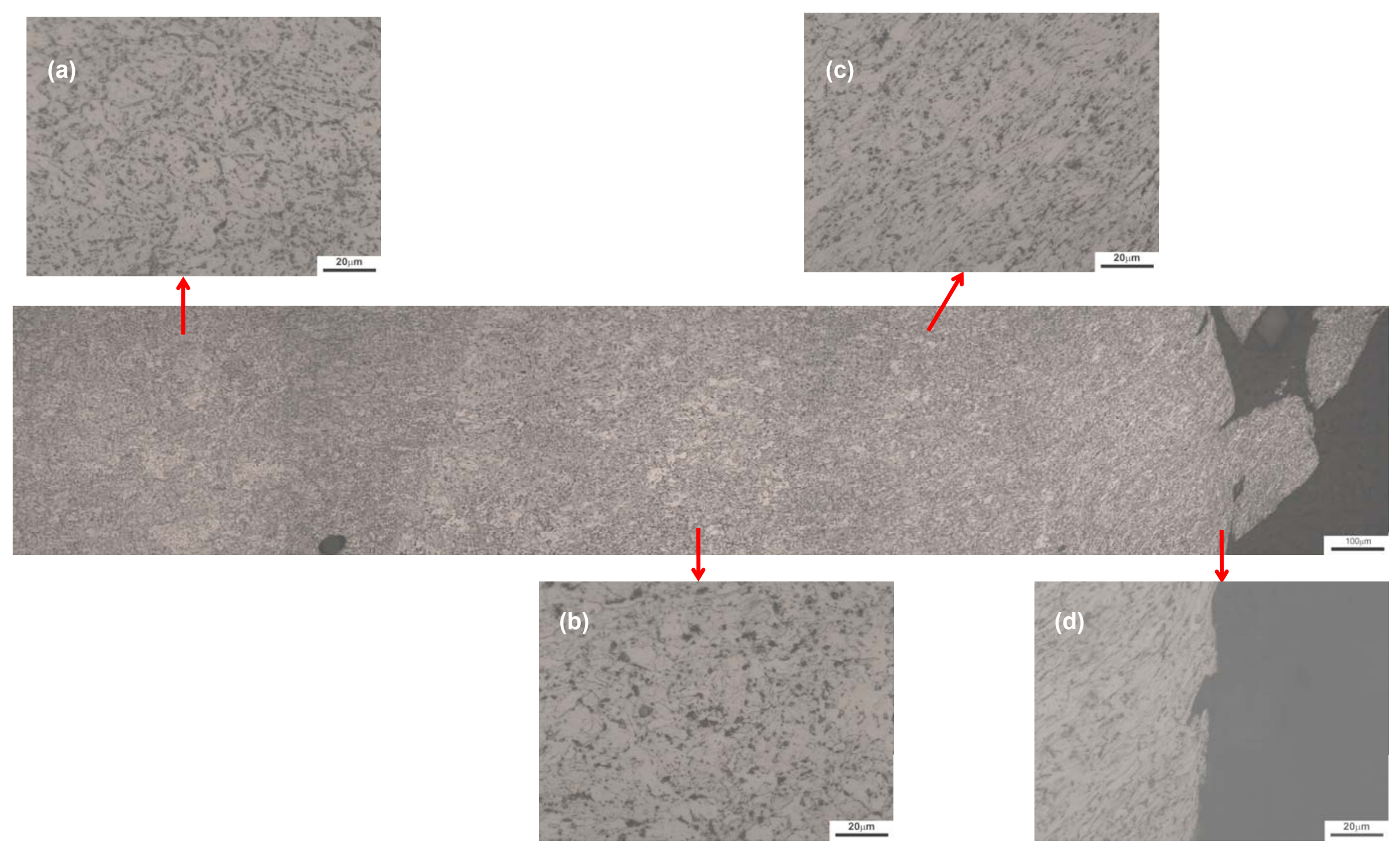

Figura 106 - Montagem da microestrutura na região de fratura do corpo de prova da ZAC do quadrante 4 do tubo 1 em sentido perpendicular ao entalhe, apresentando propagação na direção do metal de base, mostrando o metal de solda (a), ZAC (b), ZAC na região intercrítica (c) e região de fratura (d). Nota-se a semelhança da microestrutura com a da face superior do cubo da figura 71 . Reagente: Nital $2 \%$ 


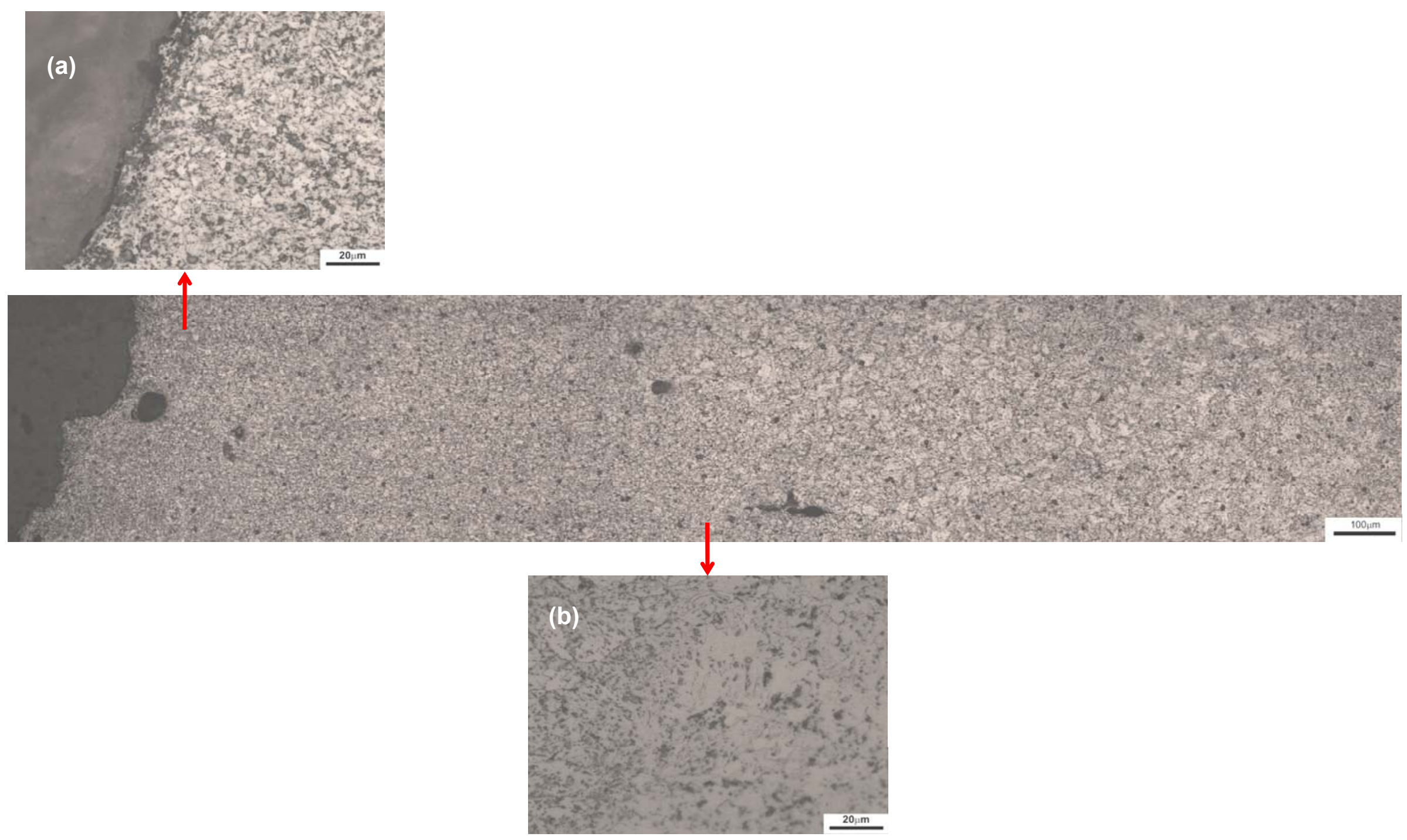

Figura 107 - Montagem da microestrutura na região de fratura do corpo de prova da ZAC do quadrante 4 do tubo 1 no sentido transversal ao entalhe, apresentando propagação tanto na ZAC quanto na ZF, mostrando a Zona Fundida (a), ZAC (b). Reagente: Nital $2 \%$. 
A figura 108 apresenta os resultados da energia absorvida média em relação às regiões do corpo de prova e aos quadrantes para o tubo 2. Os valores foram comparados com a energia média obtida para o metal de base.

Pela análise da figura 108, observa-se que houve grande variação entre a energia absorvida e a região ensaiada, embora menos do que o tubo 1. Em alguns quadrantes (Q1 e Q4), a energia absorvida no passe de raiz ficou abaixo do mínimo especificado pela norma API 5L para o sentido longitudinal $\left(101 \mathrm{~J} \mathrm{a} 0^{\circ} \mathrm{C}\right.$ ), sendo que todos estão bem distantes da média obtida pelo metal de base. O certificado do consumível utilizado nos passes de raiz apresenta energia absorvida de $101 \mathrm{~J} \mathrm{a}-29^{\circ} \mathrm{C}$, logo a $0^{\circ} \mathrm{C}$ esperava-se encontrar um maior valor de energia absorvida, o que também não foi encontrado, embora seja maior que os valores encontrados no tubo 1. Uma das possíveis razões para este comportamento também reside na maior taxa de resfriamento obtida pelo passe de raiz, mas em contrapartida em relação ao tubo $1 \circ$ teor de $\mathrm{Mn}$ encontrado foi menor, o que de certa forma contribuiu para se obter maiores valores de energia absorvida.

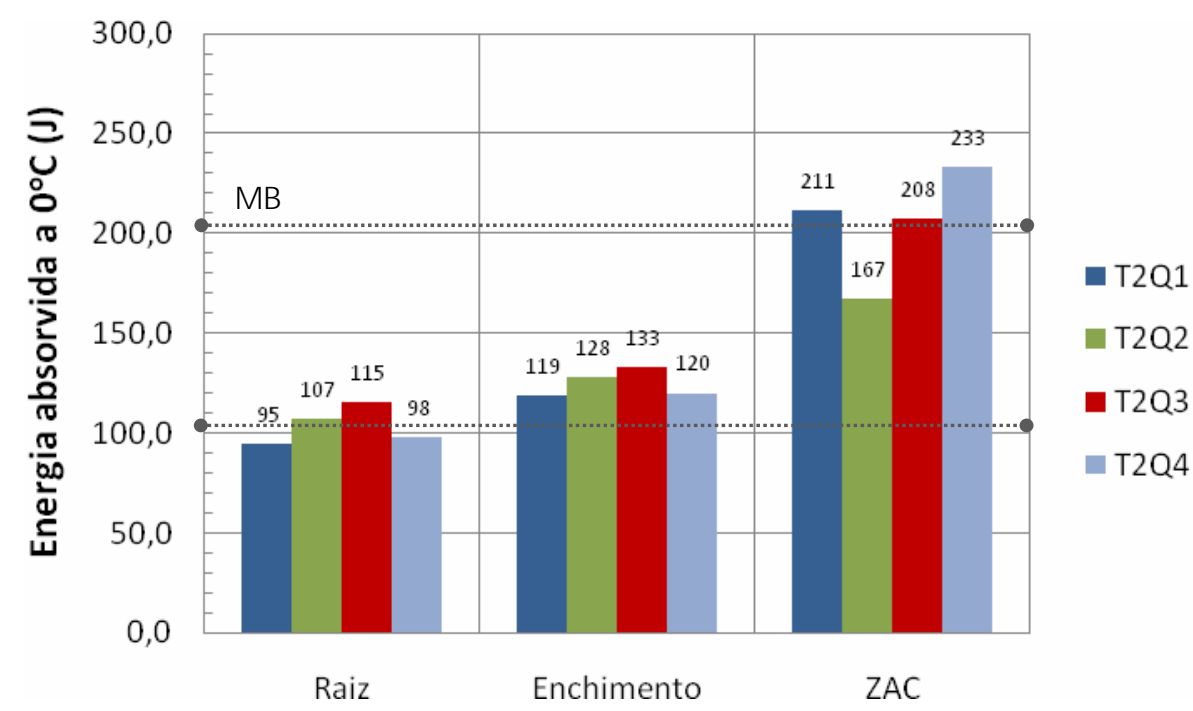

Figura 108- Energia absorvida pelas diferentes regiões da junta soldada do tubo 2, segundo os quadrantes. 
Ainda, pela análise da figura 108, é possível notar que os valores da energia absorvida pela região dos passes de enchimento situaram-se entre os valores da raiz e da ZAC, atingindo em todos os quadrantes o mínimo requerido pela norma API $5 \mathrm{~L}$ [9] e situando-se abaixo da média do metal de base, com comportamento mais uniforme entre as regiões ensaiadas em relação ao tubo 1. Uma possível causa para este comportamento é a menor velocidade de resfriamento encontrada em relação ao passe de raiz, prevenindo a formação de maior quantidade de microestruturas frágeis.

Observando-se os valores de energia absorvida da ZAC nota-se que estas foram as maiores energias absorvidas obtidas entre todas as regiões da junta soldada, ficando acima da energia absorvida mínima da norma API 5L[9] e também acima da média do metal de base. A causa deste fenômeno é que a ZAC possui maior refino de grão.

\subsubsection{Expansão Lateral:}

A figura 109 apresenta os valores de expansão lateral em relação à região da junta soldada e seus respectivos quadrantes para o tubo 1.

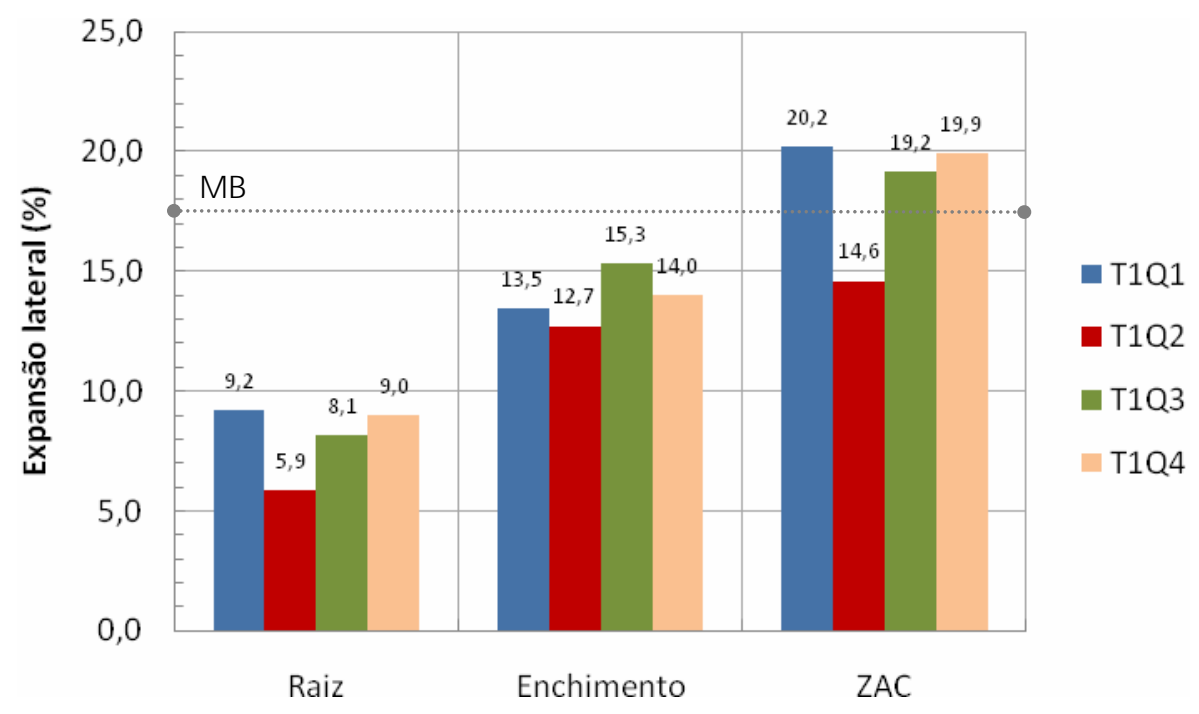

Figura 109- Valores de expansão lateral em relação a região da junta soldada e seus respectivos quadrantes. Tubo 1. 
Pela análise da figura 109, pode-se observar que a região do passe de raiz obteve o menor valor de expansão lateral, o que significa que esta região é a que apresentou menor ductilidade frente as demais regiões da junta soldada. Esta menor ductilidade também pode ser relacionada com o fato da maior velocidade de resfriamento e o do maior teor de $\mathrm{Mn}$ encontrado nesta região.

A região dos passes de enchimento e acabamento apresentou ductilidade intermediária entre os passes de raiz e a ZAC, sendo que também ficou abaixo da media do metal de base. A explicação para este fenômeno também reside no fato de menor velocidade de resfriamento ter sido obtida em relação ao passe de raiz, o que evitou a formação de maior quantidade de fases frágeis.

Já a região da ZAC apresentou ductilidade acima da do metal de base em três quadrantes. Este fenômeno está relacionado com o maior refino de grão presente nesta região.

A figura 110 apresenta os valores de expansão lateral em relação a região da junta soldada e seus respectivos quadrantes para o tubo 2.

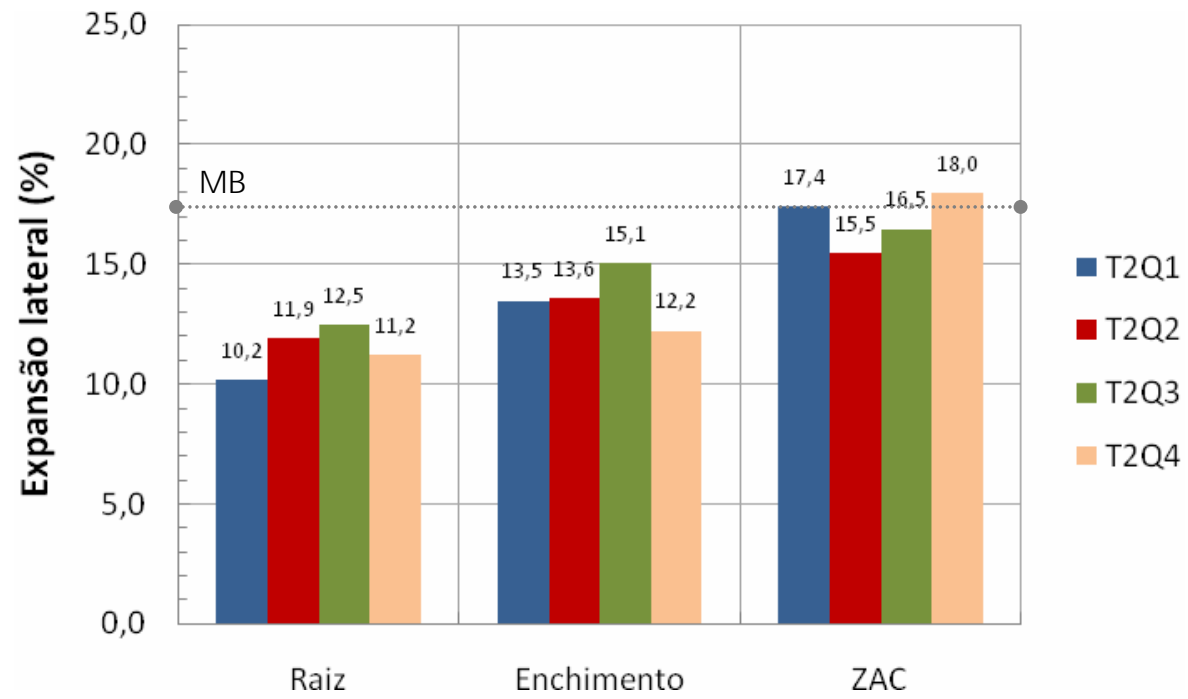

Figura 110 - Valores de expansão lateral em relação a região da junta soldada e seus respectivos quadrantes. Tubo 2.

Pela análise da figura 110, pode-se observar que a região do passe de raiz também obteve o menor valor de expansão lateral, embora mais próximo do apresentado pelo metal de base. Esta é a região que apresentou menor ductilidade frente às demais regiões da junta soldada. Esta menor ductilidade 
também pode ser relacionada com o fato da maior velocidade de resfriamento do passe de raiz em relação aos demais passes.

A região dos passes de enchimento e acabamento apresentou ductilidade intermediária entre os passes de raiz e a ZAC, sendo que também ficou abaixo da media do metal de base, entretanto apresentou comportamento mais uniforme entre as regiões da junta soldada em relação ao tubo 1. A explicação para este fenômeno também reside no fato de menor velocidade de resfriamento ter sido obtida em relação ao passe de raiz, o que evitou a formação de maior quantidade de fases frágeis.

Já a região da ZAC apresentou ductilidade acima ou igual ao do metal de base em dois quadrantes. Este fenômeno está relacionado com o maior refino de grão desta região. 


\section{CONCLUSÕES:}

Com base nos materiais utilizados, experimentos realizados e nos resultados obtidos, é possível concluir que:

1. De acordo com os dados de composição química do metal de solda depositado, é possível concluir que a composição química do passe de raiz foi bastante influenciada pela diluição do $1^{\circ}$ passe do enchimento, para ambos os tubos, pois o passe de raiz apresentou elementos de liga presentes originalmente no consumível do enchimento, fato este comprovado pela análise do certificado do consumível da raiz e pela comparação entre os passes de raiz de ambos os tubos.

2. Os valores de $\mathrm{CE}$ e do $\mathrm{Pcm}$ obtidos pela composição química dos metais de solda depositados foram maiores que o do metal de base, podendo-se concluir que estes possuem maior temperabilidade, especialmente para os passes de raiz, o que em conjunto com a maior velocidade de resfriamento, conduz a formação de microestruturas frágeis.

3. O passe de raiz (processo MAG-TC), em todos os quadrantes de ambos os tubos, apresentou menor energia de soldagem, menor tempo de resfriamento $\left(\Delta \mathrm{t}_{8-5}\right)$ e maior velocidade de resfriamento em relação aos passes de enchimento e acabamento. Analisando-se somente estes dados e não levando em consideração a temperatura de préaquecimento, pode-se concluir que esta característica é inerente ao processo empregado na deposição do passe de raiz.

4. Os passes de enchimento e acabamento apresentaram maior uniformidade nas velocidades de resfriamento, quando comparadas com todos os quadrantes.

5. A ZAC dos passes de raiz foi notadamente maior em relação aos passes de enchimento e acabamento, devido ao reaquecimento provocado pelo $1^{\circ}$ passe do enchimento.

6. A microestrutura resultante, tanto do metal de base, quanto dos metais de solda consiste principalmente de ferrita acicular, agregados eutetóides e microconstituinte MA. 
7. De maneira geral, a quantidade de MA encontrada na ZAC é superior ao encontrado no metal de base, segundo o ensaio de saturação magnética. Estes resultados foram compatíveis com os resultados obtidos por metalografia quantitativa. O metal de solda da raiz apresenta quantidade de MA superior ao do metal de base, devido ao maior carbono equivalente e maior velocidade de resfriamento imposta pelo processo de soldagem.

8. A determinação do teor de austenita retida pelo ensaio magnético proporciona uma medida mais precisa do que o método de metalografia quantitativa, pois a amostra ensaiada representa um volume, e não somente uma pequena área. Da mesma maneira, o ensaio de saturação magnética detecta fases não observáveis a olho nú. A limitação da técnica empregada foi a localização das regiões de interesse e a elaboração do corpo-de-prova.

9. Em geral, as durezas Vickers encontradas para o metal de solda foram menores que as do metal de base. A ZAC apresentou dureza mais baixa do que o metal de solda e o metal de base.

10. O limite de resistência à tração do tubo 1 foi praticamente igual ao do tubo 2, mesmo sendo o consumível empregado no tubo 1 de menor resistência, segundo a classificação AWS. Este resultado é devido provavelmente ao teor maior de $\mathrm{Mn}$ e $\mathrm{Al}$ no tubo 1 , aumentando a resistência mecânica e ao teor de $\mathrm{O}$ mais alto no enchimento do tubo 2 , o qual é prejudicial para as propriedades mecânicas.

11. Praticamente todos os corpos de prova de dobramento do tubo 1 apresentaram trincas, embora estas estejam dentro do critério de aceitação da API 1104, provavelmente devido ao maior teor de $\mathrm{Mn}$ e Al encontrados, ocasionando diminuição da ductilidade.

12. No ensaio de nick-break houve um corpo de prova reprovado no quadrante 2 do tubo 1 , devido à parada e reinício da soldagem do passe de raiz, evidenciando o quão importante é a soldagem sem interrupções.

13. A energia absorvida pelo passe de raiz de ambos os tubos foi menor em comparação com o enchimento e a ZAC e situando-se muito abaixo da energia absorvida do metal de base e da mínima especificada na norma API 5L, notadamente para o tubo 1. O tubo 2 apresentou maior 
tendência em relação a uniformização dos resultados. Este fenômeno está provavelmente relacionado com o maior carbono equivalente, a maior velocidade de resfriamento do passe de raiz e os sucessivos reaquecimentos, proporcionando a formação de microestruturas mais frágeis.

14. Os corpos de prova do ensaio de impacto na região da ZAC, de modo geral, obtiveram os maiores valores de energia absorvida e expansão lateral, do que os passes de enchimento e de raiz. Este fenômeno está relacionado com o maior refino de grão da ZAC, principalmente na região aquecida dentro da faixa de temperatura intercrítica.

15. Em relação à qualificação de procedimento de soldagem segundo a norma API 1104, o tubo 2 foi considerado aprovado em todos os ensaios requeridos, enquanto que o tubo 1 foi considerado reprovado somente no quadrante 2 , devido à falta de fusão na raiz observada no corpo de prova do ensaio de nick-break.

16. O processo MAG-TC em conjunto com o AT para enchimento e acabamento apresentaram-se como uma alternativa viável para a substituição do processo ER na soldagem de tubos de aço API $5 \mathrm{~L}$ X80. Entretanto, o processo MAG-TC necessita de maior habilidade do soldador, em relação ao processo ER. 


\section{SUGESTÃO DE TRABALHOS FUTUROS:}

1. Estudar a soldabilidade do tubo API $5 \mathrm{~L}$ X80 empregando outras combinações/processos de soldagem e/ou consumíveis;

2. Verificar a influência da velocidade de resfriamento nas propriedades mecânicas e microestruturas formadas no metal de solda e metal de base utilizando-se diferentes temperaturas de pré-aquecimento e interpasse;

3. Estudar a influência dos parâmetros de soldagem do processo MAG-TC na microestrutura e propriedades mecânicas. 


\section{REFERÊNCIAS BIBLIOGRÁFICAS:}

1. WAINER, E.; BRANDI, S. D.; MELO, F. D. H. Soldagem: Processos e Metalurgia. São Paulo: Edgar Blücher, 1995. 494 p.

2. SANTOS NETO, N. F. Caracterização de Soldas em Aços API $5 \mathrm{~L}$ Com Diferentes Arames Tubulares e Temperaturas de Pré-Aquecimento, 2003. 110 p. Dissertação (Mestrado) - Faculdade de Engenharia Mecânica, Universidade Estadual de Campinas, Campinas. 2003

3. RATNAPULI, R. C. Considerações Metalúrgicas de Fabricação dos Aços para Tubos API 5L. 62 ${ }^{\circ}$ Congresso Anual da ABM, 2007, Vitória - ES. Associação Brasileira de Metalurgia e Materiais. 2007

4. ORDOÑEZ, R. E. C. Soldagem E Caracterização das Propriedades Mecânicas de Dutos de Aço API 5L X80 Com Diferentes Arames Tubulares, 2004. 130 p. Dissertação (Mestrado) - Faculdade de Engenharia Mecânica, Universidade Estadual de Campinas, Campinas. 2004.

5. BAI, Y. Pipelines and Risers. Elsevier. 2001. p. $353-380$

6. SPECIFICATION For Low-Alloy Steel Electrodes and Rods For Gas Shielded Arc Welding: A5.28-96. American Welding Society. Miami. 1996

7. SPECIFICATION For Low-Alloy Electrodes For Flux Cored Arc Welding: A5.29-98. American Welding Society. Miami. 1998

8. WELDING of Pipelines and Related Facilities: API Specification 1104. American Petroleum Institute. 20 Ed. Washington. 82 p. 2005

9. SPECIFICATION for Line Pipe: API Specification 5L. American Petroleum Institute. $43^{\circ}$ Ed. Washington. 154p. 2000

10. FERREIRA, S. R. et Al. State of The Art Production of Gas Pipelines In Brazil. Stress Corrosion Cracking In Pipelines: A CBMM International Seminar. Rio de Janeiro: Companhia Brasileira de Metalurgia e Mineração, 2001. p. 8 - 34.

11..HARASE, J., SHIMIZU, R., TAKASHIMA, K. E WATANABE, K. - "High Speed Tack Welding Technology". Trans. Iron Steel Inst. Japão, vol. 27 (1987), p. 995. 
12. MALCOLN, J. G. A Guide for Understanding \& Specifying Chemical Composition of High Strength Linepipe Steels. Companhia Brasileira de Metalurgia e Mineração, 2007. 37 p. (Relatório Técnico)

13. HIGH-Strength Structural and High-Strength Low-Alloy Steels: HSLA Steels. Properties and Selection: Iron Steels and High Performance Alloys. Metals Handbook, Vol 6. American Society of Metals. $10^{\circ}$ Ed., 1997. p. 1009 - 1102

14.MEESTER, B. The Weldability of Modern Structural Steels. ISIJ International, Vol. $37, N^{\circ} .6$, p. $537-551.1997$

15. SICILIANO, F. Materiais para Gasodutos: Aços de Alta Resistência para Dutos de Transporte de Gás e Petróleo - Tendências Atuais. Metalurgia \& Materiais. São Paulo: Vol. 64, №. 588, p. 208 - 211, Mai/2008

16. HILLENBRAND, H. G. et Al. Procedures, Considerations for Welding X80 Line Pipe Established. Oil \& Gas Journal, Vol 37, p. 47 - 56, Set/1997

17. VALIM, M. T. Tenacidade À Fratura da Junta Soldada Obtida a Arco Submerso de Aço API 5L X80. 2005. p. 86. Dissertação (Mestrado) Departamento de Ciência dos Materiais e Metalurgia, Pontifícia Universidade Católica do Rio de Janeiro. 2005

18.ROZA, E. J. et Al. API 5L X80 ERW Pipelines: TenarisConfab \& Usiminas Development. $6^{\text {th }}$, International Pipeline Conference, 2006. Proceedings. Alberta, Canadá, American Society of Mechanical Engineers, 2006. $7 \mathrm{p}$.

19. TARIQ, M. et Al. Development of API Grade Linepipe Steels At Saudi Iron \& Steel Company. The Saudi Engineering Conference, 6 2002 , Dhahran: 2002, Vol 5, p. $327-335$

20. LLEWELLYN, D. T.; HUDD, R. C. Steels: Metallurgy and Applications. $3^{\circ}$ Ed. Woburn: Butterworth - Heinemann, 2004. 403 p.

21. BOTT, I. S. High Grade Steel Development. Materials Science Forum, Vol. 426 - 463, p. $1463-1468,2003$

22. PALMER, A. C.; KING, R. A. Subsea Pipeline Engineering. $2^{\circ}$ Ed. PennWell Books, 2008. 575 p.

23. HULKA, K. High Strength Large Diameter Pipe Plate from Standard Production To X80/X100. Produzido Por: Companhia Brasileira de 
Metalurgia e Mineração. Disponível em: http://www.cbmm.com.br/portug/sources/techlib/info/others_in_pdf/pdfs/h igh_strength_large.pdf. Acessado em: Mar/09.

24. OMWEG, G. M. et Al. Performance of Welded High-Strength Low-Alloy Steels in Sour Environments. Corrosion, Vol. 59, № 7, p. 640 - 653, Julho/2003

25. HULKA, K.; BORDIGNON, P.; GRAY, J. M. Experience With Low Carbon HSLA Steel Containing 0,006 To 0,10 Percent Niobium. Araxá: Companhia Brasileira de Metalurgia e Mineração, 2003. 29 p. (Relatório Técnico Nióbio, N01/04)

26. RAMÍREZ, M. F. G. Estudo da Transformação Durante O Resfriamento Contínuo e da Microestrutura do Aço Microligado X80 Utilizado $\mathrm{Na}$ Construção de Tubos para Transporte de Gás Natural e Petróleo, 2008, 158 p. Dissertação (Mestrado) - Escola Politécnica da Universidade de São Paulo. São Paulo: 2008

27. BOTT, I. S. et Al. High-Strength Steel Development for Pipelines: A Brazilian Perspective. Metallurgical and Materials Transactions A, Vol 36 A, p. $443-454.2005$

28. TAISS, J. M. O Mercado de Aços de Elevado Valor Agregado, Tendências Tecnológicas e a Estratégia da Usiminas No Atendimento Às Demandas: Workshop - Inovações para Desenvolvimento de Aços de Alto Valor Agregado - Tubos de Alta Resistência para Aplicações Estruturais e Transmissão de Fluídos. $62^{\circ}$ Congresso Anual da ABM, 2007, Vitória - ES: Associação Brasileira de Metalurgia e Materiais, 2007.

29. SICILIANO, F. Recent Trends In High Strength Linepipe Steels. São Paulo: Companhia Brasileira de Metalurgia e Mineração. [2007]

30. HILLENBRAND, H. G. Et Al. Development of High Strength Material and Pipe Production Technology for Grade X120 Line Pipe. International Pipeline Conference, 2004. Proceedings. Alberta, Canadá, American Society of Mechanical Engineers, 2004. 9 p.

31. SILVA, M. C. Caracterização das Propriedades Mecânicas e Metalúrgicas do Aço API $5 \mathrm{~L}$ X80 e Determinação Experimental de Curvas J-R para Avaliação da Tenacidade a Fratura, 2004, 117 p. 
Dissertação (Mestrado) - Escola Politécnica da Universidade de São Paulo. São Paulo: 2004

32. SILVA, J. H. F.; ORDOÑEZ, R. E. C.; TREVISAN, R. E. Estudo de Trincas Induzidas Pelo Hidrogênio No Metal de Solda do Aço API 5L X80 Através do Teste G-BOP. $3^{\circ}$ Congresso Nacional de Engenharia Mecânica, 2004, Belém - PA, CONEM, 2004

33. BATISTA, G. Z. et al. Avaliação da Microestrutura e Propriedades Mecânicas de Tubo API 5L X80 Submetido À Curvamento Por Indução. Tecnologia em Metalurgia e Materiais, São Paulo, Vol. 3, №. 4, p. 16-22, Abr. - Jun./2007

34. CALOI, G. Análise da Soldabilidade do Aço API $5 \mathrm{~L}$ X80 Por Meio dos Testes Tekken e de Implante, 2008, 145 p. Dissertação (Mestrado) Departamento de Ciência dos Materiais e Metalurgia, Pontifícia Universidade Católica do Rio de Janeiro: 2008

35. PINTO, P. M. A. S. Soldagem Circunferencial de Tubo API 5L X80 Empregando Processos Manual / Semi-Automático, 2006, 113 p. Dissertação (Mestrado) - Departamento de Ciência dos Materiais e Metalurgia, Pontifícia Universidade Católica do Rio de Janeiro: 2006

36. DURAND, R. Z. S. Avaliação da Microestrutura e Propriedades Mecânicas da Soldagem Circunferencial do Aço API 5L X80 Por Processos de Soldagem Semi-Automáticos Com Proteção Gasosa, 2007, 143 p. Dissertação (Mestrado) - Departamento de Ciência dos Materiais e Metalurgia, Pontifícia Universidade Católica do Rio de Janeiro: 2007

37. DURAND, R. S. et Al. Qualificação de Procedimento para Soldagem Circunferencial de Tubos API 5L X80. Rio Pipeline 2007: Conference \& Exposition, 2007, Rio de Janeiro: Instituto Brasileiro do Petróleo, 2007. $10 \mathrm{p}$.

38. TUBOS de Grande Diâmetro: Propriedades Mecânicas. Produzido Por Usiminas. Disponível em: <http://www.usiminas.com.br/secao/0,3381,131,00.html?cat=> Acessado em: Fev./2007

39. PROCESSO de Fabricação: ERW Longitudinal - Linha Contínua. Produzido Por TenarisConfab. Disponível em: 
<http://www.tenaris.com/tenarisconfab/pt/prodser/linepipe.aspx>

Acessado em: Mar/2009

40. SMITH, W.; ROBERTS, J. High-Frequency Welding. Welding Brazing and Soldering. Metals Handbook, Vol 6, 10 Ed. American Society of Metals, 1998. p. $736-740$

41.PROCESSO de Fabricação: SAW Longitudinal - UOE. Produzido Por TenarisConfab.

Disponível

em:

<http://www.tenaris.com/tenarisconfab/pt/prodser/linepipe.aspx>

Acessado em: Mar/2009

42. TENARIS-CONFAB. (Pindamonhangaba, SP). Tubos para Condução: Linepipe: Catálogo. Pindamonhangaba: 2004

43. OGBORN, J. Submerged Arc Welding. Welding Brazing and Soldering. Metals Handbook, Vol 6, 10 Ed. American Society of Metals, 1998. p. $618-642$

44. CARY, H.; HELZER, S. Modern Welding Technology. $6^{\circ}$ Ed, PrenticeHall, 2004. 736 p.

45. WELDING Process. The Procedure Handbook of Arc Welding. $43^{\circ}$ Ed. Cleveland: The James F. Lincoln Arc Welding Foundation, 2000. 742 p.

46. PARANHOS, R.; SOUZA, A. C. Soldagem Ao Arco Submerso. Coleção Soldagem 2000. Rio de Janeiro: Serviço Nacional de Aprendizagem Industrial, 2000. 77 p.

47. JENNEY, C.L. (Editor), O'BRIEN, A. (Editor) - "AWS Welding Handbook, Volume 1 - Welding Science and Technology", 9a. edição, American Welding Society, EUA, pg 573, 2001.

48.BRANDI, S. D. - "Metalurgia da soldagem: soldabilidade de alguns materiais". In: Zieldas, S; Tatini, I; org. Soldagem. São Paulo : SENAI, pp. 115-123, 1997.

49.BOTT, I. S.; KOJIMA, S. S.; SAMPAIO, M. A. The Development of API $5 \mathrm{~L}$ X80 Steel For Pipeline Productions by the TMCR Process. T\&B Petroleum, Rio de Janeiro, No 15, p. 68 - 70, 2003

50. CAMPBELL, R. D.; WALSH, D. W. Weldability Testing. Welding Brazing and Soldering. Metals Handbook, Vol 6, 10 Ed. American Society of Metals, 1998. p. $1484-1514$ 
51. METALURGIA da Soldagem, Apostila do Curso de Inspeção de Soldagem N1, Fundação Brasileira de Tecnologia da Soldagem. Rio de Janeiro: 2008, pg 25.

52.THOMPSON, A.W.; BERNSTEIN, I.M. - "Microstructure and hydrogen embrittlement". In: "Hydrogen effects in metals", Bernstein, I.M. e Thompson, A.W. (editores), AIME, EUA, pp 291-308, 1980.

53.BEACHEM, C.D. - "A new model for hydrogen-assisted cracking (hydrogen embrittlement)". Met. Trans., vol 3A, no. 2, pp. 437-451, 1972.

54. GRANJON, H. - "La fissuration à froid en soudage d'aciers". Soud. Tecn. Conn., vol 26, no. 3/4, pp 155-164, 1972.

55. GRANJON, H. - Bases métallurgiques du soudage, Publicação 'La Soudure Autogène', Paris - França, pp, 80-84, 1991.

56. BAYLEY, N. - Welding steels without hydrogen cracking, 2a. edição, Cambridge, Abington, pp.1-15, 1993.

57.BRANDI, S. D. Metalurgia da Soldagem: Transferência de Calor. ZIEDAS, S.; TATINI, I. Coleção Tecnologia SENAI: Soldagem. São Paulo: Serviço Nacional de Aprendizagem Industrial, 1997, Cap. 2, p. 93-102.

58. EASTERLING, K. Introduction to the physical metallurgy of welding, 2a. edição, Butterworth-Heinemann, Oxford, Inglaterra, pp, 18-30, 1992.

59. BERNARD, G. - "A viewpoint on the weldability of carbon-manganese and microalloyed structural steels". IN: International Symposium on High-Strength Low-Alloy Steels (Micro Alloying 75), Washington EUA, 13 de outubro, pp. 552-569, 1975.

60.HART, P.H.M.; DOLBY, R.E.; BAILEY, N.; WIDGERY, D.J. - "The weldability of microalloyed steels". IN: International Symposium on High-Strength Low-Alloy Steels (Micro Alloying 75), Washington EUA, 13 de outubro, pp. 540-551, 1975.

61.MARQUET, F.; BRAGARD, A.; FIKKERS, A.T.; MULLER, T. "Evaluation of cold cracking susceptibility". Weld. Res. Int., vol. 9, no. 2, pp. 33-53, 1979.

62. COTA, A.B.; MODENESI, P.J.; BARBOSA, R.; SANTOS, R.D "Determination of CCT diagrams by thermal analysis of an HSLA bainitic 
steel submitted to thermomechanical treatment”. Scripta Materialia Vol. 40, n. 2, pp. 165-169, 1998.

63.STALHEIM, D.G. - "The Use of High Temperature Processing(HTP) Steel for High Strength Oil and Gas Transmission Pipeline Applications". IN Fifth International Conference on HSLA Steels, Chinese Sciety of Metals, China, November 2005. In: http://www.dgsmet.com/resume.pdf , consultado em 15 de dezembro de 2009.

64. MANOHAR, P.A.; CHANDRA, T. - "Continuous Cooling Transformation Behaviour of High Strength Microalloyed Steels for Linepipe Applications". ISIJ International, Vol.38, No.7, pp.766-774, 1998.

65. CARRUCIO, V. Pipelines Welding Handbook, ESAB, 2002

66. JUERS, R. H. Shielded Metal Arc Welding. Welding Brazing and Soldering. Metals Handbook, Vol 6, 10 Ed. American Society of Metals, 1998. p. $558-569$

67. HOLLIDAY, D. B. Gas-Metal Arc Welding. Welding Brazing and Soldering. Metals Handbook, Vol 6, 10 Ed. American Society of Metals, 1998. p. $569-581$

68. WAVEFORM Control Technology®: Surface Tension Transfer®. Cleveland: The Lincoln Electric Company, 2006. 4 p. (Relatório Técnico, NX2.20 - Nov/06)

69. WAVEFORM Control Technology®: Surface Tension Transfer $®$ - Open Root. Cleveland: The Lincoln Electric Company, 2006. 6 p. (Relatório Técnico, NX3.10 - Fev/03)

70. MEYER, D. W. Flux Cored Arc Welding. Welding Brazing and Soldering. Metals Handbook, Vol 6, 10 Ed. American Society of Metals, 1998. p. $581-590$

71. RAMIREZ, J. E. Characterization of High-Strength Steel Weld Metals: Chemical Composition, Microstructure, and Nonmetallic Inclusions. Welding Journal, Vol. 87, N³, p. 65 - 75, Mai/2008.

72. FEDELE, R. Soldagem de Tubulações: Metalurgia, Procedimentos e Desafios. Metalurgia \& Materiais, São Paulo, Vol. 58, №. 521, 11 p., Mai/2002.

73. MODENESI, p. J. Normas e Qualificação em Soldagem. Universidade Federal de Minas Gerais. Disponível em: 
$<$ http://www.demet.ufmg.br/grad/disciplinas/emt019/procedimento solda gem.pdf> Acessado em: Abr./09.

74. MARTIN, R. V.; LANDGRAF, F. J. G.; GOLDENSTEIN, H.; CUMINO, R.; CAMPOS, M. F.; "Estimativa de Austenita Retida em Aços Temperados e Revenidos por Métodos Magnéticos", $17^{\circ}$ CBECIMAT, 15 - 19 de Novembro de 2006, Foz do Iguaçu, Brasil

75. THE LINCOLN ELECTRIC COMPANY. (CLEVELAND, OH). Pipeliner: Premium Pipe Welding Consumables: C1.100. Catálogo. Cleveland: Jun/2003

76. THE LINCOLN ELECTRIC COMPANY. (CLEVELAND, OH). Innershield $₫$ Wires Product Catalog: Self-Shielded, Flux Cored Wires: C3.2000. Catálogo. Cleveland: Ago/2002

77. SOLDAGEM: N-133 Rev. J, Petróleo Brasileiro S.A., Rio de Janeiro. Jul./2005

78. STANDARD Test Methods and Definitions For Mechanical Testing of Steel Products: A370, American Society For Testing and Materials. 2003

79.GRONG, O. - "Metallurgical Modelling of Welding", 2a. edição, The Institute of Materials, Londres, Inglaterra, pg 1-115, 1997. 
ANEXO I - Resulta dos do ensa io de composição química - Proaqt. 


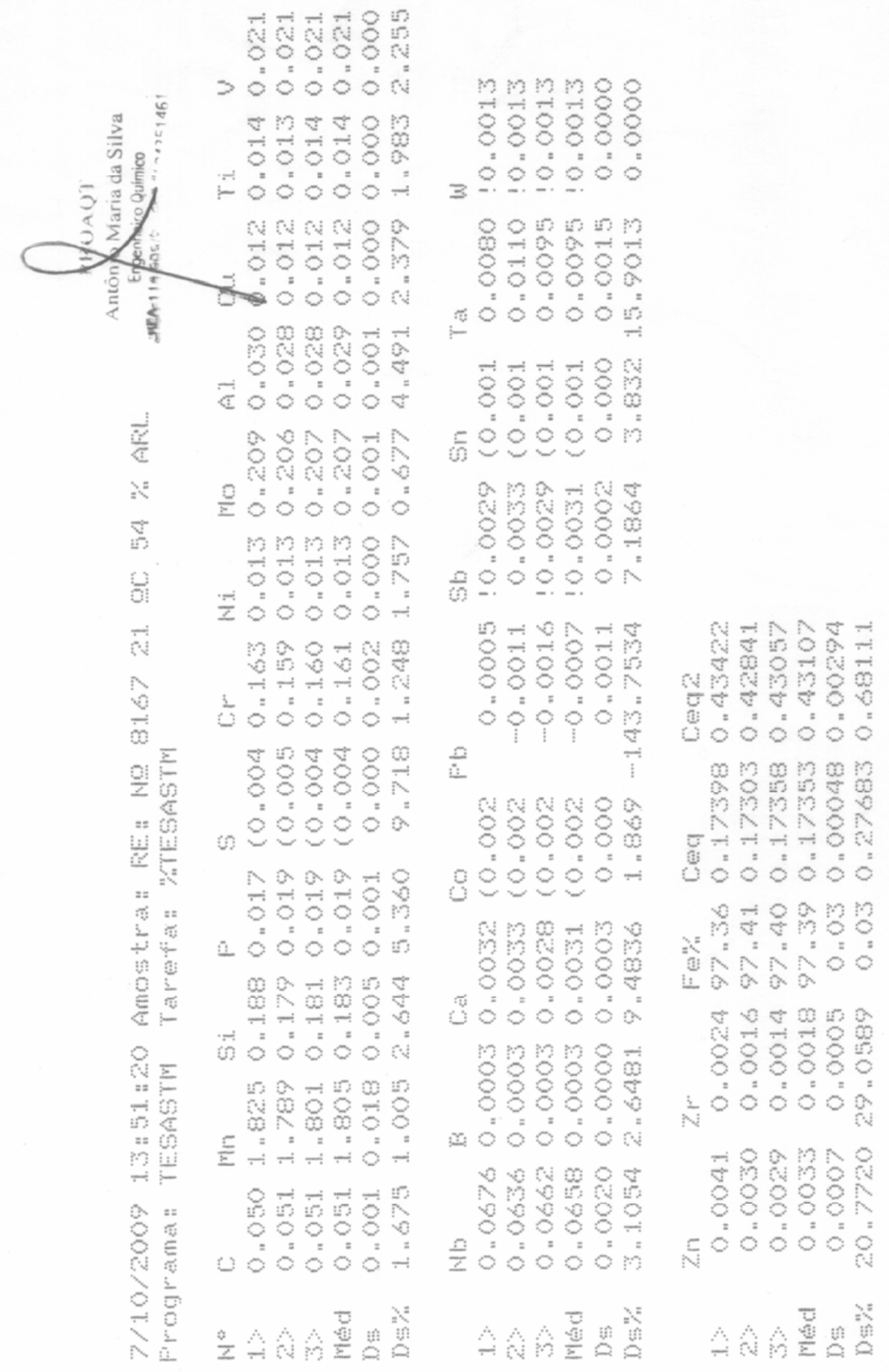


ANEXO II - Certific a do de qualidade do consumível emprega do no processo MAG-TC. 


\section{THE LINCOLN ELECTRIC COMPANY \\ 22801 St. Clair Avenue}

Cleveland, Ohio 44117-1199

\section{CERTIFIED MATERIAL TEST REPORT}

This is to certify that the following was manufactured under Lot Control per AWS A5.01-93, Class S4 Schedule K. The following test was run on .045 Pipeliner 80S-G (Q2 LOT 729T). Procedures in accordance with AWS A5.28-2005 DC+ only for classification ER80S-G were followed. This test report is in accordance with 3.1. per EN10204 and ISO 10474 3.1.B.

The product stated herein was manufactured and supplied in accordance with the Quality System Program of The Lincoln Electric Co., Cleveland, Ohio, U.S.A. as outlined in our Quality Assurance Manual. The Quality System Program of The Lincoln Electric Co. has been accepted by ASME and approved by VdTUV, and is certified to ISO 9001:2000 by Certificate No. 30275 with an expiration date of November 13, 2008.

Test Conditions

\begin{tabular}{|l|c|}
\hline Electrode Size & $.045^{\prime \prime}$ (1.1mm approx. equiv.) \\
\hline Electrode Polarity & $\mathrm{DC}+$ \\
\hline Current (amps) & 310 \\
\hline Arc Voltage (volts) & 29 \\
\hline Preheat/ Interpass Temp ${ }^{\circ} \mathrm{C}\left({ }^{\circ} \mathrm{F}\right)$ & $149(300) / 163(325)$ \\
\hline Plate ID & $\mathrm{G} 12297$ \\
\hline Shielding Gas & $80 \% \mathrm{Ar} / 20 \% \mathrm{CO} 2$ \\
\hline
\end{tabular}

Mechanical Properties
\begin{tabular}{|l|c|c|}
\hline *Yield Strength, .2\% offset method MPa (ksi) & $615(89)$ & AWS A5.28-2005 \\
\hline *Tensile Strength MPa (ksi) & $707(103)$ & Not Specified \\
\hline${ }^{*}$ Elongation \% & 22 & $550 \mathrm{MPa}(80 \mathrm{ksi}) \mathrm{min}$. \\
\hline
\end{tabular}

Impact Properties

\begin{tabular}{|l|c|c|}
\hline Joules @ -29 $\mathrm{C}$ & $110,99,95=101$ ave & Not Specified \\
\hline (ft-lbs. @ -20 $\mathrm{F}$ ) & $(81,73,70=75$ ave $)$ & Not Specified \\
\hline
\end{tabular}

\section{Radiographic Inspection Results}

\begin{tabular}{|l|l|l|}
\hline Plate G12297 & PASSED & MET REQUIREMENTS \\
\hline
\end{tabular}

Wire Chemistry

\begin{tabular}{|l|c|c|}
\hline \% Carbon & .100 & Not Specified \\
\hline$\%$ Manganese & 1.70 & Not Specified \\
\hline$\%$ Silicon & .59 & Not Specified \\
\hline$\%$ Phosphorous & .014 & Not Specified \\
\hline$\%$ Sulfur & .009 & Not Specified \\
\hline$\%$ Nickel & .02 & .50 min. $^{\star \star}$ \\
\hline$\%$ Chromium & .02 & .30 min. $^{\star \star}$ \\
\hline$\%$ Molybdenum & .45 & .20 min $^{* \star}$ \\
\hline$\%$ Vanadium & .003 & Not Specified \\
\hline$\%$ Copper (Total) & .211 & Not Specified \\
\hline
\end{tabular}


LOT $729 T$

Diffusible Hydrogen

\begin{tabular}{|l|l|l|}
\hline Per AWS A4.3 (ml/100g weld metal) & $1.4,1.2,1.4,1.4=1.4$ ave & REPORT ONLY.
\end{tabular}

*The strength and elongation properties were obtained from $12.5 \mathrm{~mm}$ ( $0.500 \mathrm{in}), \mathrm{A} 4$ tensile specimen artificially aged at $105^{\circ} \mathrm{C}\left(220^{\circ} \mathrm{F}\right)$ for 48 hours, as permitted by AWS A5.28-2005. A naturally aged tensile specimen may take months to achieve the specified properties. See AWS A5.28-2005, paragraph A8.3.

The time required for the natural aging of weld deposit is dependent upon ambient conditions, weldment geometry, the metallurgical structure of the weld deposit and other factors.

${ }^{* *}$ In order to meet the requirements of the " $\mathrm{G}$ " classification, the electrode must have a minimum of one or more of these elements.

This is to certify that the contents of this report are correct and accurate as contained in the records of The Lincoln Electric Company.
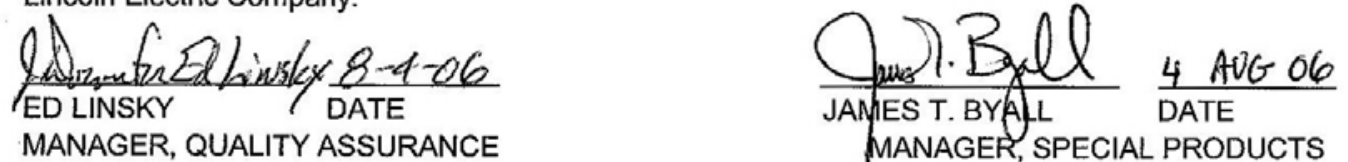

"Note: The recording of false, fictitious or fraudulent statements or entries on this document may be punished as a felony under Federal Statutes including Federal Law, Title 18, Chapter 47." 
ANEXO III - Certific a do de qualida de do consumível empregado no processo AT-AP. 


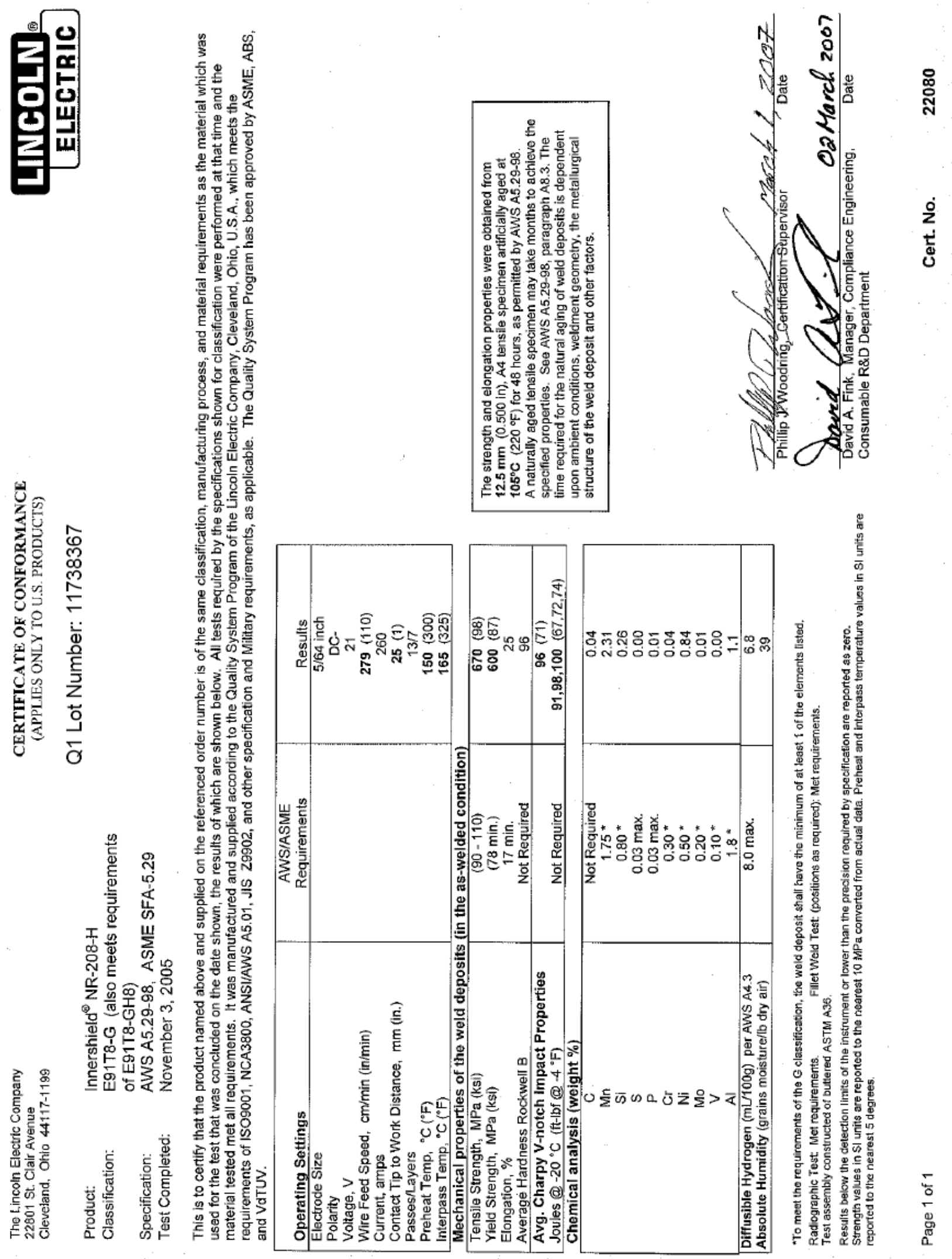


ANEXO IV - Certific ado de qualidade do consumível emprega do no processo AT-PG. 
THE LINCOLN ELECTRIC COMPANY

22801 St. Clair Avenue

Cleveland, Ohio 44117-1199

\section{CERTIFIED MATERIAL TEST REPORT}

This is to certify that the following was manufactured under Lot Control per AWS A5.01-93, Class T4, Schedule I, plus Diffusible Hydrogens. The following test was run on .045" Pipeliner G80M (Q2 LOT 716R). Procedures in accordance with AWS A5.29-98, DC+ only for classification E101T1-GM and E101T1-GMH8 were followed. This test report is in accordance with 3.1.B per EN10204 and ISO 10474 3.1.B.

The product stated herein was manufactured and supplied in accordance with the Quality System Program of The Lincoln Electric Co., Cleveland, Ohio, U.S.A as outlined in our Quality Assurance Manual. The Quality System Program of The Lincoln Electric Co. has been accepted by ASME and approved by VdTUV, and is certified to ISO 9001:2000 by Certificate No. 30275 with an expiration date of November 21, 2005.

Test Conditions

\begin{tabular}{|l|l|}
\hline Electrode Size $(\mathrm{mm})$ & $.045^{\prime \prime}$ \\
\hline Electrode Polarity & $\mathrm{DC}+$ \\
\hline Current (amps) & 235 \\
\hline Arc Voltage (volts) & 27 \\
\hline Preheat Interpass Temp $(\circ \mathrm{F})$ & $300 / 300$ \\
\hline Shielding Gas Used & $75 \% \mathrm{Ar} / 25 \% \mathrm{CO}_{2}$ \\
\hline Plate ID & $716 \mathrm{R} 1$ \\
\hline
\end{tabular}

As Welded Mechanical Properties

PLATE 716R1

AWS A5.29-98 (E101T1-GM and E101T1-GMH8)

\begin{tabular}{|l|c|c|}
\hline Yield Strength, .2\% offset method (ksi) & 98 & $88 \mathrm{ksi}$ min \\
\hline Tensile Strength $(\mathrm{ksi})$ & 104 & $100-120$ \\
\hline Elongation $(\%)$ & 22 & $16 \%$ min \\
\hline
\end{tabular}

Charpy V-Notch ft. Ibs.

\begin{tabular}{|l|l|l}
\hline @ $-20^{\circ} \mathrm{F}$ & $44,35,38=39$ AVE. & NO SPEC.
\end{tabular}

Radiographic Requirement

\begin{tabular}{|l|l|l}
\hline As Welded & Met Requirements & AWS A5.29-98 \\
\hline
\end{tabular}

Deposit Chemistry

\begin{tabular}{|l|c|c|}
\hline \% Carbon & .042 & NO SPEC \\
\hline \% Manganese & 1.61 & 1.75 min. $^{*}$ \\
\hline \% Phosphorous & .02 & .03 max. \\
\hline \% Sulfur & .01 & .03 max. \\
\hline \% Silicon & .34 & .80 min. $^{*}$ \\
\hline \% Nickel & 1.01 & .50 min. $^{*}$ \\
\hline$\%$ Chromium & .03 & .30 min $^{*}$ \\
\hline$\%$ Molybdenum & .27 & .20 min. $^{*}$ \\
\hline$\%$ Vanadium & .02 & .10 min. $^{*}$ \\
\hline$\%$ Aluminum & $<.01$ & 1.8 min. $^{*}$ \\
\hline \% Copper & .030 & NO SPEC \\
\hline
\end{tabular}

$-1-$ 
LOT 716R

DIFFUSIBLE HYDROGEN

ANSI/AWS A $4.3(\mathrm{~mL} / 100 \mathrm{~g})$

$6.9,6.3,7.1,6.4=6.7$ AVE.

8.0 MAX

* In order to meet the alloy requirements of the "G" group, the undiluted weld metal shall have the minimum of at least one of the elements listed in this table.

This is to certify that the contents of this report are correct and accurate as contained in the records of The Lincoln Electric Company.

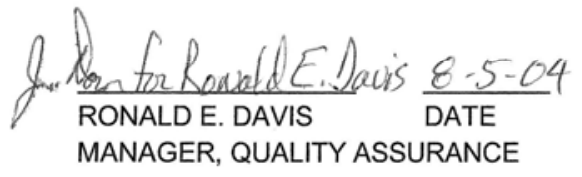

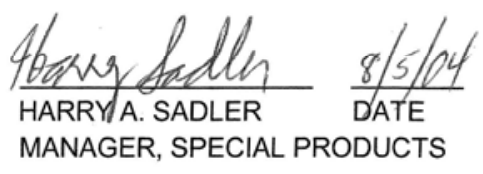


ANEXO V - Especificação do procedimento de soldagem para os dois tubos. 
Especificação de Procedimento de Soldagem do experimento 1 - EPS01

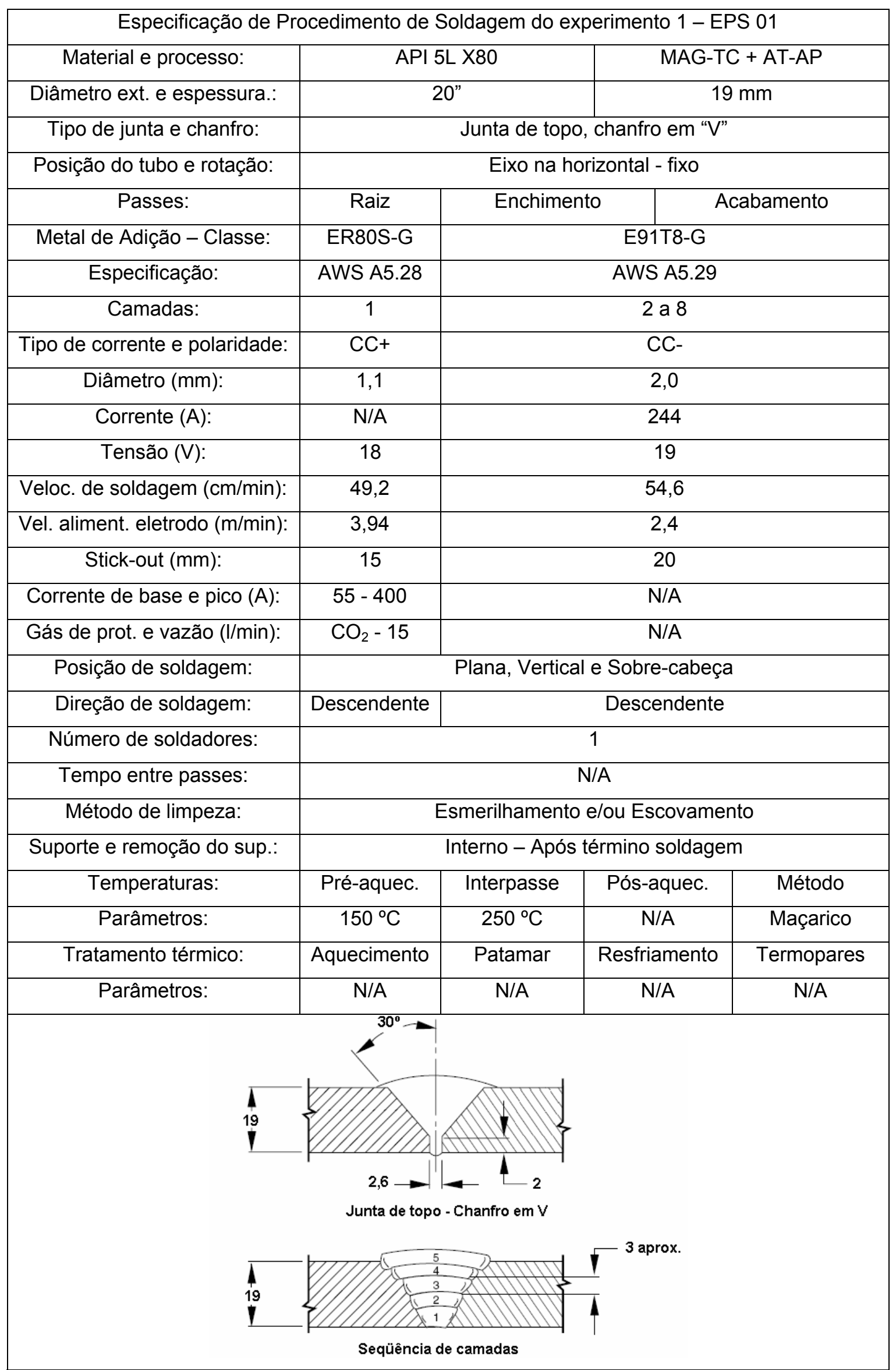


Especificação de Procedimento de Soldagem do experimento 2 - EPS 02

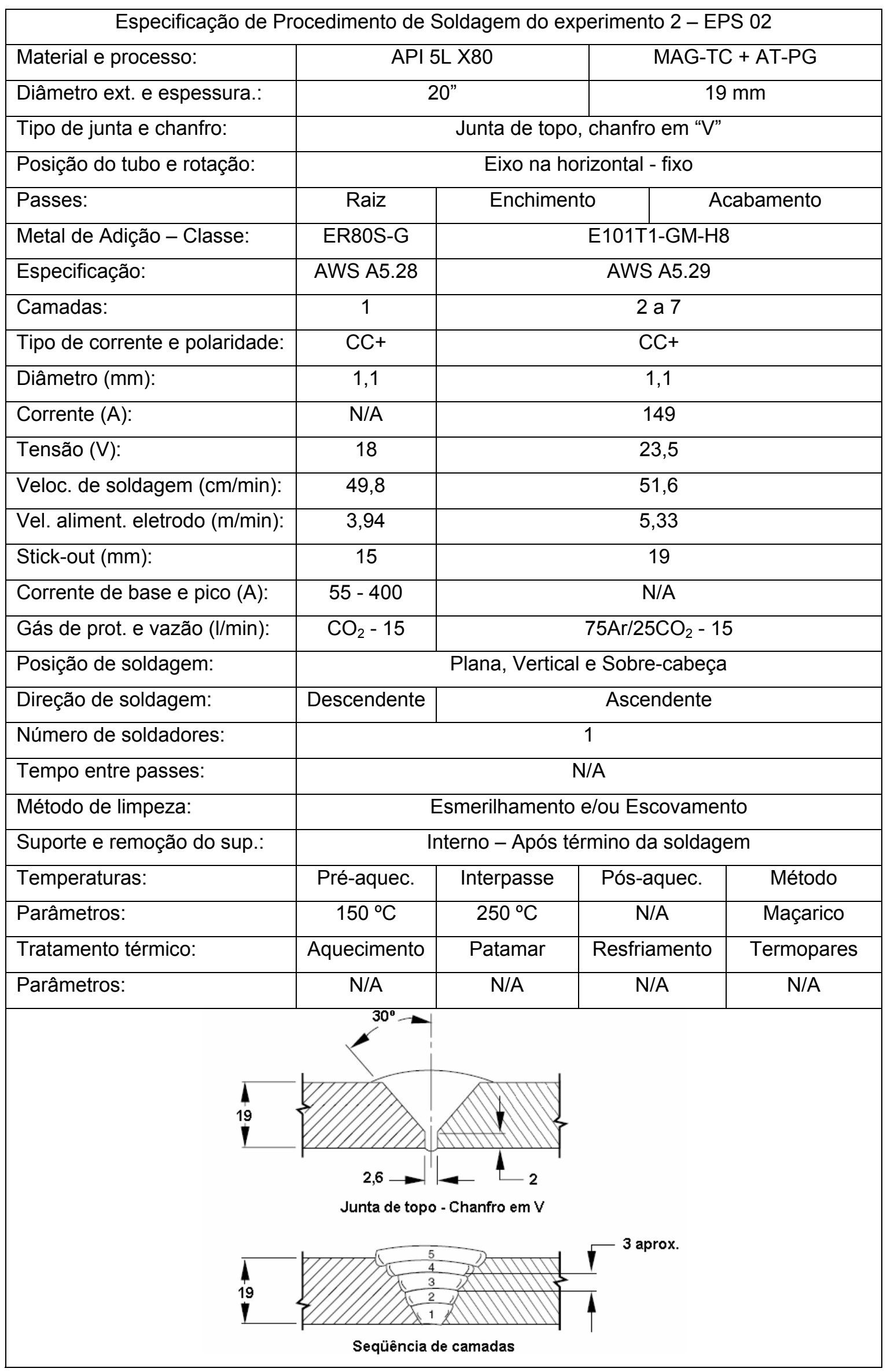


ANEXO VI - Parâ metros de soldagem utiliza dos pela literatura. 


\section{Parâmetros de soldagem utilizados pela literatura.}

\begin{tabular}{|c|c|c|c|c|c|c|}
\hline & Ref. [34] & Ref. [35] & Ref. [36] & Ref. [4] & Ref. [16] & Ref. [71] \\
\hline Material & $\mathrm{X} 80$ & $\mathrm{X} 80$ & $\mathrm{X} 80$ & $\mathrm{X} 80$ & $\mathrm{X} 80$ & $\mathrm{X} 80$ \\
\hline Diâmetro (pol) & Chapa & $20 "$ & $20 "$ & Chapa & $\mathrm{NE}$ & $\mathrm{NE}$ \\
\hline Espessura (mm) & 19 & 19 & 19 & 19 & NE & NE \\
\hline Processo & SMAW/FCAW-G & SMAW/FCAW-S & GMAW-STT@/FCAW-G & FCAW-S e FCAW-G & GMAW & GMAW-STT@/FCAW-S \\
\hline Metal de Adição & E8010-G/E101T1-GM H8 & E6010/E9010-G/E-91T8-G & ER80S-G/E101T1-GM H8 & E71T8-K6/E71T-1 & ER70S-6/ER90S-G & ER70S-6/E91T8-G \\
\hline Corrente (A) & $\mathrm{NE}$ & $158 / 170 / 244$ & NE & $\sim 200 / 190$ & $190-220 / \sim 220-260$ & NE \\
\hline Tensão (V) & 23,5 & $28 / 26 / 21$ & $\sim 22,5$ FCAW & $\sim 23$ & $19-21 / 22-26$ & NE \\
\hline Polaridade & NE & CC-/CC+/CC- & $\mathrm{CC}+$ & CC-/CC+ & NE & NE \\
\hline Vel. Soldagem. $(\mathrm{mm} / \mathrm{s})$ & $\sim 4,25$ & $\mathrm{NE}$ & $\mathrm{NE}$ & $250 / 200(\mathrm{~cm} / \mathrm{min})$ & $75 / 26-45(\mathrm{~cm} / \mathrm{min})$ & NE \\
\hline Vel. Alim. Elet. (mm/s) & $\mathrm{NE}$ & NE & $4,3 / 6,9 / 7,6$ & $\sim 4,0 / 3,5$ & NE & NE \\
\hline Stick-out (mm) & NE & $15-20$ & NE & $22 / 19$ & NE & NE \\
\hline Corr. Base e Pico (A) & NA & NA & $55 / 415$ & NA & NA & NE \\
\hline Gás de Proteção & $80 \% \mathrm{Ar} / 20 \mathrm{CO}_{2}$ & NA & $\mathrm{CO}_{2} / 75 \% \mathrm{Ar}-25 \% \mathrm{CO}_{2}$ & $\mathrm{CO}_{2}$ & $75 \% \mathrm{Ar}-25 \% \mathrm{CO}_{2} / \mathrm{CO}_{2}$ & $\mathrm{CO}_{2}$ \\
\hline Energia de Sold. (KJ/mm) & NE & $0,62 / 0,80 / 1,02$ & NE & $1,5 / 1,15$ & $3,7 / 3,1-9,0$ & $\sim 1,2$ \\
\hline$\Delta \mathrm{T} 8-5(\mathrm{~s})$ & NE & $4,8 / 6,2 / 7,9$ & $\mathrm{NE}$ & NE & NE & $\mathrm{NE}$ \\
\hline Pré-aquec. $\left({ }^{\circ} \mathrm{C}\right)$ & $100^{\circ} \mathrm{C}$ & $100^{\circ} \mathrm{C}$ & $100^{\circ} \mathrm{C}$ & 100 e $160^{\circ} \mathrm{C}$ & NE & NE \\
\hline Interpasse $\left({ }^{\circ} \mathrm{C}\right)$ & NE & $175^{\circ} \mathrm{C}$ & $150^{\circ} \mathrm{C}$ & NE & NE & 120 \\
\hline Pós-aquec. $\left({ }^{\circ} \mathrm{C}\right)$ & NE & NE & NE & NE & NE & NE \\
\hline Limite de Res. (Mpa) & NE & $\sim 700$ & $\sim 674$ & 630 & NE & NE \\
\hline Limite de Esc. (Mpa) & NE & NE & NE & 555 & NE & NE \\
\hline Impacto: $(\mathrm{J})$ & NE & MB 160J/Raiz 50J/MS65J & NE & $\begin{array}{l}100^{\circ} \mathrm{C}-74 \mathrm{~J} \text { MS-232 ZAC } \\
160^{\circ} \mathrm{C}-38 \mathrm{~J} \mathrm{MS}-211 \text { ZAC } \\
100^{\circ} \mathrm{C}-40 \mathrm{~J} \mathrm{MS}-180 \mathrm{ZAC} \\
160^{\circ} \mathrm{C}-46 \mathrm{~J} \mathrm{MS} 180 \mathrm{ZAC}\end{array}$ & NE & $\mathrm{NE}$ \\
\hline
\end{tabular}


